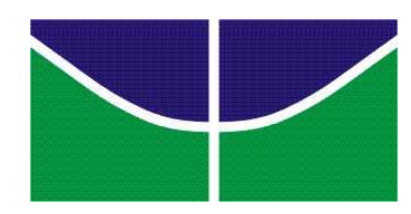

UNIVERSIDADE DE BRASÍLIA

PROGRAMA DE PÓS-GRADUAÇÃO EM ENSINO DE CIÊNCIAS MESTRADO PROFISSIONAL EM ENSINO DE CIÊNCIAS

\title{
RACIOCÍNIO QUALITATIVO E DESENVOLVIMENTO DE RACIOCÍNIO HIPOTÉTICO-DEDUTIVO: UMA PROPOSTA PARA ALUNOS SURDOS
}

FABRÍCIO BECHEPECHE ALVES

Brasília, DF

Julho

2015 


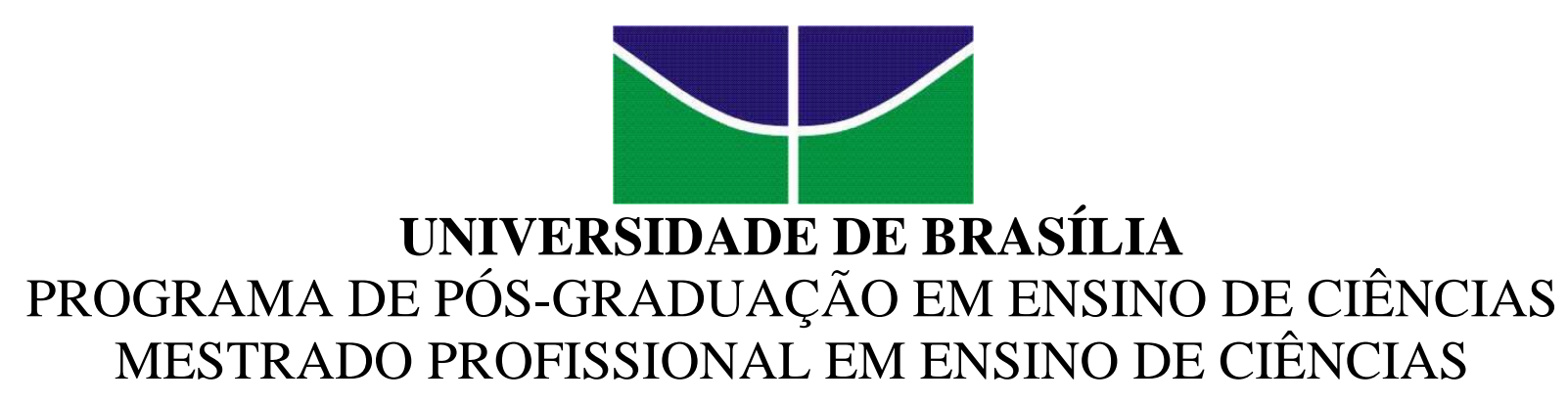

\section{RACIOCÍNIO QUALITATIVO E DESENVOLVIMENTO DERACIOCÍNIO HIPOTÉTICO-DEDUTIVO: UMA PROPOSTA PARA ALUNOS SURDOS}

\section{FABRÍCIO BECHEPECHE ALVES}

Dissertação realizada sob orientação do Prof. Dr. Paulo Sérgio Bretas de Almeida Salles e apresentada à banca examinadora como requisito parcial à obtenção do Título de Mestre em Ensino de Ciências - Área de Concentração "Ensino de Biologia", pelo Programa de PósGraduação em Ensino de Ciências da Universidade de Brasília.

Brasília, DF

Julho

2015 


\title{
FOLHA DE APROVAÇÃO
}

\author{
Fabrício Bechepeche Alves
}

\section{"Raciocínio Qualitativo e Desenvolvimento de Raciocínio Hipotético- Dedutivo: uma proposta para alunos surdos"}

Dissertação apresentada à banca examinadora como requisito parcial àobtenção do Títulode Mestre em Ensino de Ciências pelo Programa de Pós-Graduação em Ensinode Ciências (PPGEC) da Universidade de Brasília (UnB).

Aprovada em 28 de julho de 2015.

\section{BANCA EXAMINADORA}

Prof. Dr. Paulo Sérgio Bretas de Almeida Salles- IB/UnB (Presidente)

\author{
Prof. ${ }^{a}$ Dr. ${ }^{a}$ Maria Márcia Murta - IQ/UnB \\ (Membro Titular)
}

Prof. ${ }^{a}$ Dr. ${ }^{a}$ Heloisa Maria Moreira Lima Salles -LIP/UnB (Membro Titular)

Prof. Dr. Ricardo Gauche - IQ/UnB

(Membro Suplente) 
Dedico este trabalho aos meus pais, Elísio e Maria das Graças, aos meus filhos, Gabriel e Nathália, e àminha esposa, Joyce. Todo o meu esforço e conquistas são para nos proporcionar condições melhores. 


\section{AGRADECIMENTOS}

Foram várias as pessoas que colaboraram de alguma forma durante todo o processo de construção desse estudo e das trocas de experiências que muito contribuíram para o meu crescimento pessoal e profissional. Por isso gostaria de agradecer:

Primeiramente a Deus, por me dar forças para sempre seguir em frente e por iluminar minha vida, mostrando-me sempre o caminho do bem e das coisas boas que sempre procuro seguir, segundo a minha fé.

Aos meus pais, Elísio e Maria das Graças, que sempre me apoiaram e estiveram ao meu lado, me ajudando e dando o suporte necessário para que pudesse seguir nessa empreitada.

Aos meus filhos, Nathália e Gabriel, que, mesmo privando-se de momentos importantes ao lado do pai, mantinham o amor e os olhares puros, alimentando a saudade para saciá-la quando eu chegasse em casa, ou saísse do computador.

Minha esposa Joyce, que cuidou muito bem dos nossos filhos nos momentos em que se fazia necessário, e também pela força e apoio prestado em todo o trajeto desta pesquisa.

Ao meu orientador, professor Paulo Sérgio Bretas de Almeida Salles, que me ajudou a compreender a importância da realização de uma pesquisa científica, com ética, com responsabilidade, com compromisso, e acima de tudo, com o prazer em fazer o que se gosta. Obrigado por acreditar em mim e também pela oportunidade de participar de um projeto inovador e com grande relevância para a construção do conhecimento científico e para a Educação de um modo geral.

À professora Mariana de Senzi Zancul, por suas aulas e por me acalmar em meus desabafos, mostrando-me um caminho de maturidade, ética e respeito necessários para se prosseguir.

Aos colegas de curso, que proporcionaram vários debates enriquecedores e contribuíram para o meu amadurecimento e para o respeito às diversas visões sobre um mesmo assunto.

Ao Tarcísio Cavalcante, que compartilhou da execução de diversas atividades das disciplinas que cursamos juntos e por dividir as mesmas aflições e expectativas acerca do mestrado, quando um dava apoio ao outro. 
A todos os professores do PPGEC da UnB, que sempre buscaram desenvolver uma inquietação nos alunos, de forma a adquirirmosconhecimento e participar ativamente do processo de construção do saber.

Ao Professor Ricardo Gauche, por trabalhar com comprometimento e respeito, ajudando-me a desenvolver um pensamento mais apurado com o rigor metodológico envolvido em uma pesquisa, mas acima de tudo, contribuindo para me tornar um ser mais reflexivo e pensante.

Ao professor Marcelo Bizerril, pela grande contribuição na formação de umapercepção mais apurada sobre a "natureza" e como trabalhar isso de uma forma em que o aluno perceba que ele próprio faz parte dela.

À professora Maria Luiza de Araujo Gastal e ao professor Wildson L. Pereira dos Santos, que souberam ter a paciência necessária para nos receber nas primeiras aulas do mestrado e por nos estimular a querer passar por um processo de desconstrução, e a partir daí, refletir com mais clareza sobre temas de grande importância para o Ensino de Ciências, abandonando grande parte da visão ingênua e positivista que carregávamos sobre conhecimentos científicos. Deixo aqui também um agradecimento especial ao professor Wildson, que nos presenteou compartilhando seu vasto conhecimento sobre CTS.

À professora Maria Márcia Murta pela participação na banca de defesa dessa dissertação e pela colaboraçãono sentido de melhorar o desenvolvimento dessa pesquisa.

Às professoras Maria Rita Avanzi e Patrícia Machado por dirigirem o curso de Mestrado de forma harmoniosa, promovendo a valorização do curso como um todo.

Aos professores Gerson Mól, Renata Razuck e Juliana Caixeta, que me proporcionaram tardes maravilhosas e gostosas, nas quais pudemos conhecer um pouco mais sobre a educação inclusiva. Ao professor Gerson Mól, agradeço pelas críticas construtivas, que serviram como estímulo para buscar melhorar e fazer um trabalho de qualidade, dando a devida importância ao tema da inclusão. E às professoras Renata e Juliana, quero deixar um agradecimento especial pela doçura e carinho com que nos trataram.

Às direções do CEF-CASEB e do Centro Educacional 06 - Taguatinga (CED06 ou Escola Bilíngue de Taguatinga), que nos abriram as portas e deram todo o suporte necessário para a realização dos cursos que preparamos.

Às professoras Gisele Morisson Feltrini e Mônica Maria Pereira Resende, por intercederem junto àEscola Bilíngue, para permitira realização do curso, o que foi de grandeimportância para este trabalho, e também por serem parte do referencial teórico desta pesquisa. 
Às secretárias Jesa Lima, do NECBio, CarolinaKozue Okawachi,do IQ, e Luciene Mendes, do PPGEC, pelo suporte e orientações e apoio na tramitação de documentos, sempre que necessário.

Às coordenadoras Márcia Esteves, do CEF-CASEB, e Eliã, da Escola Bilíngue de Taguatinga, por serem comprometidas com a educação e por toda a ajuda e suporte oferecidos para a realização dos cursos nessas escolas.

A todos os professores, intérpretes e alunos surdos, que participaram dos cursos e se dispuseram a gastar um tempo para contribuir de forma significativa para esta pesquisa.

Às amigas Rejane Caixeta e Geane Pereira, pelos materiais, conversas e tantas outras coisas que me ajudaram, colegas por quem guardo um carinho muito especial.

À professora Heloisa Maria Moreira Lima Salles, por contribuir de forma ativa e participativa, inclusive sendo referencial para essa pesquisa.

À Secretaria de Estado de Educação do Distrito Federal, por me conceder o afastamento remunerado que possibilitou me envolver e realizar esta pesquisa durante o curso de Mestrado.

A todos amigos, familiares e pessoas que me apoiaram e me incentivaram na realização desse sonho! 


\section{RESUMO}

Este trabalho tem por objetivo aelaboração da propostade um curso baseado nouso de Modelagem Qualitativa para aquisição de conceitos científicos por alunos surdos dentro de um contexto bilíngue. Para isso, foram utilizados e avaliados materiais didáticos baseados em Modelos Qualitativos (MQ) construídos na bancada de modelagemDynaLearn,buscando explorar silogismos e raciocínio hipotético-dedutivo de forma interativa e visualmente atrativa, por meio de modelos e de simulações.Para coletar os dados e verificar a hipótese desta pesquisa, foi aplicadoum curso-piloto junto a alunos surdos de uma escola da rede pública de ensino do Distrito Federal, localizada em Taguatinga, Distrito Federal.Os dados foram coletados por meio de questionários, entrevistas realizadas com professores intérpretes, exercícios e testes respondidos por alunos, e posteriormente,submetidos a análises qualitativas e estatísticas Os resultados mostraram relatos de impressões positivas por parte dos professores intérpretes e comprovados pelos resultados dos questionários e testes aplicados aos alunos.Trabalhar com Raciocínio Qualitativo fazendo uso demodelageme apresentada de forma adaptada em um contexto bilínguemostrou-se ferramenta valiosa na educação científica de alunos surdos do Ensino Médio, com grande potencial de interatividade e de desenvolvimento do raciocínio hipotético-dedutivo.Com base nesses resultados, foi construída uma proposta de curso na qual é descrito o passo-a-passo de como utilizar modelos de simulação dentro de um contexto bilíngue (LIBRAS/Português escrito), e fazer uso de recursos visuais para tornar mais compreensivo o uso de modelos qualitativos por alunos surdos.

Palavras-chave: Raciocínio Qualitativo, Modelagem Qualitativa, Raciocínio Hipotético Dedutivo, Educação de surdos. 


\begin{abstract}
This work aims at the elaboration of a course based on the use of Qualitative Modeling for acquisition of scientific concepts by deaf students in a bilingual context. For this purpose, teaching materials based on Qualitative Models (MQ), built whithinthe DynaLearn workbench, were used and evaluated seeking to exploit syllogisms and hypothetical-deductive reasoning in interactively and visually attractive way, by using models and simulations. To collect data and to verify the hypothesis of this research, a pilot course was delivered to deaf pupils in a public school in Taguatinga,Federal District. Data were collected from questionnaires, interviews with teachers and interpreters, exercises and tests answered by students, and further submitted to qualitative and statistical analyses. The results have shown reports of positive impressions on the part of teachers and interpreters, confirmed by the results of questionnaires and tests applied to students. Working with Qualitative Reasoning making use of modeling in an adapted way an in a bilingual context proved to be a valuable tool in science education of deaf high school students, because it has an attractive interface, with great potential for interactivity and for developing hypothetical-deductive reasoning. Based on these results, a proposal for a course was elaborated which describes step-by-step how to use simulation models within a bilingual context (LIBRAS / written Portuguese) and to make use of visual resources to support understanding of concepts expressed in qualitative models by deaf students.
\end{abstract}

Keywords: Qualitative Reasoning, Qualitative Modeling, Hypothetical-deductive reasoning, Deaf education. 


\section{LISTA DE ILUSTRAÇÕES}

Figura 1- Modelo "Poluição Rio"e simulação........................................................................32

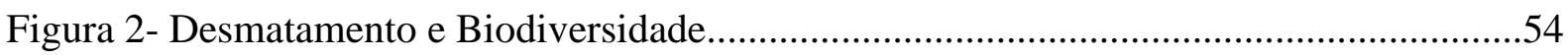

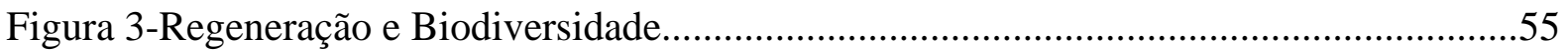

Figura 4- Desmatamento, Erosão, Produção agrícola e Riqueza econômica.............................56

Figura 5- Produção de milho e Riqueza econômica...............................................................57

Figura 6- Regeneração, Erosão, Produção agrícola e Riqueza econômica...............................57

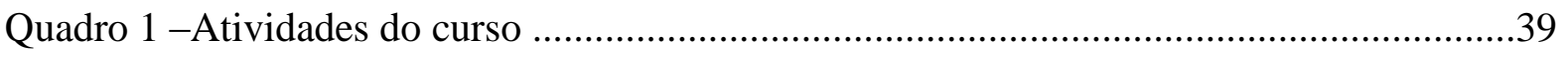

Quadro 2 -Resultado questionário avaliação alunos surdos ...............................................62 


\section{LISTA DE TABELAS}

Tabela 1 - Frequências das notas dos alunos na Atividade 1 1................................................44

Tabela 2 - Frequências das notas dos alunos na Atividade 2 2................................................46

Tabela 3 - Frequências das notas dos alunos na Atividade 3 ...............................................54

Tabela 4 - Frequências de acertos e de erros em cada item do modelo 'Desmatamento e

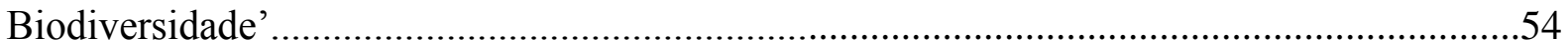

Tabela 5 - Frequências de acertos e de erros em cada item do modelo 'Regeneração e

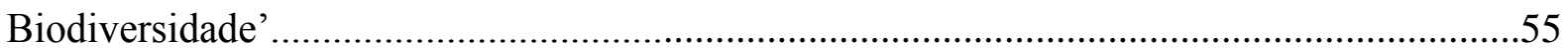

Tabela 6 - 'Desmatamento, Erosão, Produção agrícola e Riqueza econômica' ........................56

Tabela 7 - 'Regeneração, Erosão, Produção agrícola e Riqueza econômica' ...........................58

Tabela 8 - Frequênciasdas notas dos alunos na Atividade 4..............................................59

Tabela 9 - Frequênciasdas notas de todos os alunos que fizeram o Pré-teste...........................60

Tabela 10 - Frequências das notas dos alunos no Pré-teste.....................................................60

Tabela11 - Frequência das notas dos alunos no pós teste que participaram de todas as

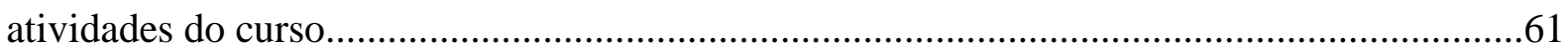




\section{LISTA DE ABREVIATURAS E SIGLAS}

SEE/DF Secretaria de Estado de Educação do Distrito Federal

IA Inteligência Artificial

RQ Raciocínio Qualitativo

MQ Modelagem Qualitativa

LS Learning Space (Espaço de Aprendizagem) no

$\mathrm{P}$ Proporcionalidade ou influência indireta

I Influência direta

CTS Ciência, Tecnologia e Sociedade

LIBRAS Linguagem Brasileira de Sinais

LP Língua Portuguesa

ENPEC Encontro Nacional de Pesquisas em Educação em Ciências

TQP Teoria Qualitativa dos Processos 


\section{SUMÁRIO}

INTRODUÇÃO

1 EDUCAÇÃO DE SURDOS.......................................................................................19

1.1 Contexto histórico da educação de surdos................................................................19

1.2 Principais abordagens metodológicas na educação de surdos..................................22

1.3 Inclusão de surdos e trabalhos relacionados que utilizam MQ...............................24

2 UMA REVISÃO DO RACIOCÍNIO QUALITATIVO.....................................................30

2.1 Pressupostos básicos da Teoria Qualitativa dos Processos.........................................30

2.2 Raciocínio Qualitativo e DynaLearn...............................................................................31

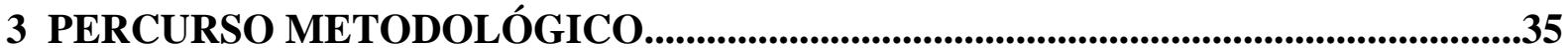

3.1 Metodologia - delimitação da unidade de caso, coleta e tratamento dos dados e relatório...........................................................................................................................................36

3.2 As atividades realizadas com os alunos e professores................................................38

3.3 Avaliação do 'Manual Instrucional' ...............................................................................40

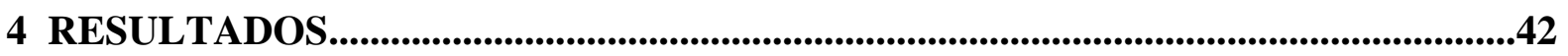

4.1 Resultados das atividades aplicadas aos alunos surdos............................................43

4.1.1 Resultado da Atividade 1 ..............................................................................4

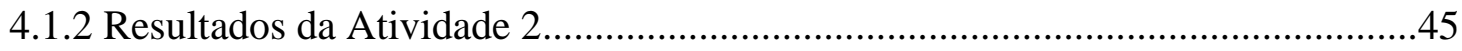

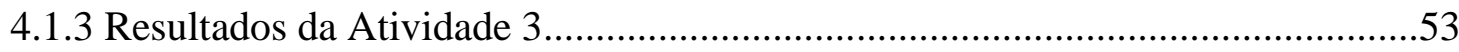

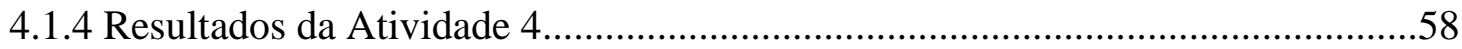

4.1.5 Resultados dos testes aplicados aos alunos surdos..............................................59

4.1.5.1 Resultados do Pré teste....................................................................59

4.1.5.2 Resultados do pós teste.....................................................................60

4.1.5.3 Resultados das análises estatísticas obtidas da comparação entre o pré e pós-teste aplicados aos alunos surdos...........................................................61

4.1.6 Resultados dos questionários de avaliação aplicados aos alunos surdos..............61

4.2 Resultados das análises das entrevistas aplicadas aos professores/intérpretes...........................................................................................................63

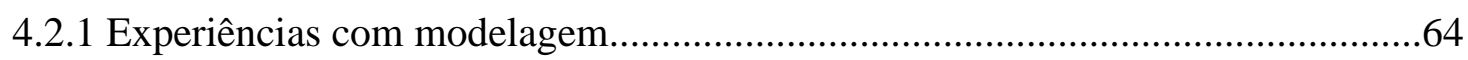

4.2.2 Modelos e Simulações.......................................................................................66

4.2.3 Usos na Educação..........................................................................................67

4.2.4 Software DynaLearn..................................................................................70 
4.2.5 Questões abertas.

4.3 Resultados da análise do 'MATERIAL INSTRUCIONAL' '..................................73

5 DISCUSSÃO

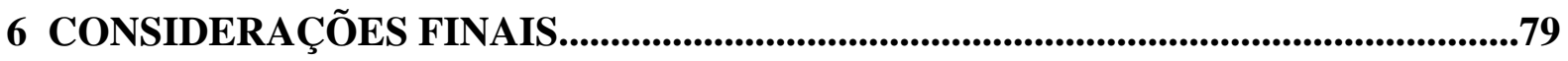

REFERÊNCIAS BIBLIOGRÁFICAS..........................................................................81

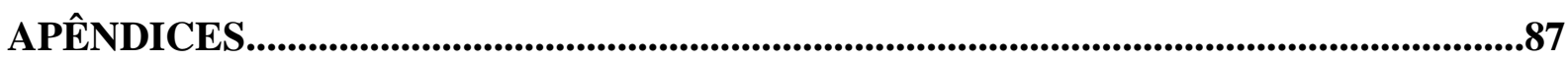

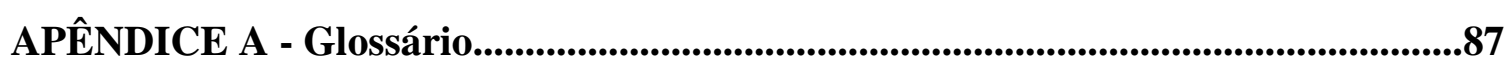

APÊEDICE B - Modelo Desmatamento LS6..........................................................................88

APÊNDICE C - Modelo Desmatamento LS2.....................................................................89

APÊNDICE D - Modelo Regeneração LS2 ............................................................90

APÊEDICE E - Pré-teste........................................................................................................91

APÊNDICE F - Pós-teste...................................................................................96

APÊEDICE G - Atividade1......................................................................................101

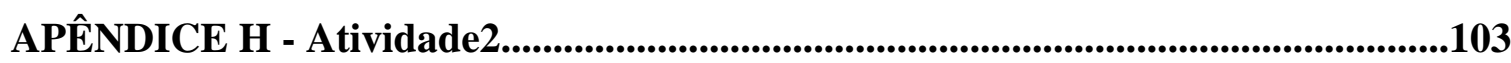

APÊNDICE I - Atividade3.....................................................................................106

APÊNDICE J - Atividade4...........................................................................................107

APÊNDICE K - Termo de consentimento..................................................................108

APÊNDICE L - Avaliação do curso- alunos surdos..................................................109

APÊNDICE M - Roteiro da entrevista e ficha de consentimento................................110

APÊNDICE N- Slides utilizados para trabalhar Silogismos e questões "Se...

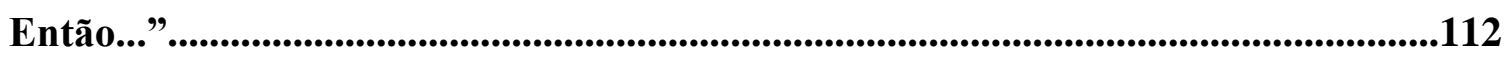

APÊNDICE O- PROPOSTA DE CURSO.......................................................................116 


\section{INTRODUÇÃO}

A educação científica de alunos surdos passou ao longo de muito tempo por diversas transformações e isso se deve muito a maneira como os surdos eram vistos perante a sociedade da época e as abordagens educacionais disponíveis em cada momento. Segundo Luchesi (2003), a educação de surdos se divide em três momentos históricos de fundamental importância para a compreensão da abordagem utilizada e a maneira como o surdo é visto nesse trabalho. O primeiro ocorreu na década de 1950. Nessa fase,o surdo era avaliado por testes psicométricos e a interpretação desses testesdeterminava que os surdos teriam um “menor nível de inteligência e uma forma diferente de raciocinar". Já na década de 1960, chegou-se a conclusão que surdos e ouvintes obtinham resultados semelhantes em provas não verbais, porém os surdos se vinculam mais ao concreto e possuem dificuldades em generalizar e com isso, gerar pensamentos abstratos. Na terceira fase, ocorrida no final da década de 1960, já sobre influência das ideias Piagetianas, afirmava-se que os surdos possuíam capacidade cognitiva semelhante à dos ouvintes e as dificuldades anteriormente relatadas passaram a ser ligadas às diferentes experiências vividas, em especial às comunicativas.

A partir das teses de Vygotsky (2001), têm sido reformuladas as idéias de subordinação do pensamento à linguagem. Suas teses baseiam-se fundamentalmente nas questões "sociointerativas" e acrescenta a essas a cultura na relação do pensamento/linguagem, que, para Luchesi (2003), “é construída durante todo o desenvolvimento individual e pela linguagem que se converte em pensamento e este em linguagem."

A partir desse último pensamento, conclui-se que o surdo deve adquirir a linguagem de sinais nas fases mais precoces da vida, de forma a constituir uma identidade própria do surdo, que possibilita o seu "desenvolvimento cognitivo, permitindo a comunicação e o ajustamento social", (LUCHESI, 2003).

Nesse sentido, o trabalho aqui apresentado busca respeitar o surdocomo um membro de uma comunidade minoritária que se comunica com particularidade linguística, sendo a linguagem de sinais sua língua natural e por isso é aqui tratada como primeira língua. Além disso, os conhecimentos científicos explorados junto aos alunos são trabalhados dentro de um contexto social e com a utilização de imagens, possibilitando maior interação e compreensão dos fenômenos apresentados por meio de modelos de simulação. 
Essa abordagem dá continuidade a esforços em trabalhar com alunos surdos explorando seu desenvolvimento cognitivo. Afinal, diversos estudos mostraram que modelos e modelagem baseada em Raciocínio Qualitativo (RQ) têm grande potencial para promover o aprendizado de conceitos por alunos ouvintes, e mais recentemente, por alunos surdos (SALLES et al. 2004) e (SALLES et al., 2005). É também reconhecido seu potencial para desenvolver o raciocínio hipotético-dedutivo, essencial para a formação do pensamento científico (PIAGET e INHELDER, 1967; CARRETERO, 1979).

Além disso, para a compreensão de muitos conceitos científicos, é fundamental entendera dinâmica dos sistemas,que dependem das interações entre objetos e de mecanismos de controle que operam e produzem o comportamento específico de cada sistema, como demonstrado em trabalhos anteriores (SALLESet al., 2004; SALLES et al., 2005; FELTRINI, 2009; RESENDE, 2010).

Para alunos surdos,raciocínio e compreensão são atividades ainda mais complexas, visto o grande atraso de aprendizagem que esses alunos acumulam devido a um déficit acadêmico. Isso ocorre por faltarprofessores capazes de promover uma mediação adequada em que se faça presente uma educação científica bilíngue (LIBRAS/Português escrito) e ferramentas didáticas apropriadas, fatos esses relatados nos trabalhos de(SALLES et al., 2004; SALLES et al., 2005; FELTRINI, 2009; RESENDE, 2010; KELMAN \& TUXI, 2011). Esses autores deram grande contribuição para a educação científica de alunos surdos, por detectarem em suas pesquisas algumas das principais dificuldades encontradas pelos surdos no processo de ensino aprendizagem, entre as quais destacam-se a forma de comunicação, a ausência de material didático apropriado e a metodologia utilizada na educação científica dos surdos.

Em Salleset al. (2004) foi realizado um trabalho que verificou a potencialidade de uso de modelos qualitativos na educação científica de alunos surdos em níveis graduais de dificuldade e avaliando a capacidade dos alunos conseguirem escrever em Português suas idéias acerca dos conceitos representados nos modelos. Esse trabalho apresentou resultados positivos e deu início a uma sequência de pesquisas dentro de um contexto de educação bilíngue utilizando o RQ.

A partir desses estudos, o presente trabalho apresenta uma proposta de curso que utiliza o RQ na forma de modelos de simulação em uma abordagem simples e que envolve o aluno no processo de construção de significados e do conhecimento ao longo de todas as atividades propostas. 
Esta pesquisa utilizou o RQ com a aplicação de modelos de simulação que buscam fornecer uma ferramenta a mais de apoio à aquisição de conceitos científicos por alunos surdos, tornando-se assim uma ferramenta didática eficaz a mais, que pode ajudar a minimizar a falta de material didático necessário a esse propósito.

A justificativa que dá suporte a essa pesquisa são os resultados de trabalhos anteriores sobre o uso doRaciocínio Qualitativo (FORBUS, 1984). Este trabalhoutilizou modelos de simulação na educação,demonstrando ser uma ferramenta capaz de desenvolver um aprendizado mais consistente e eficaz, com a utilização de recursos visuais adequados para o desenvolvimento de um raciocínio lógico e perceptivo acerca dos fenômenos que nos cercam (SALLESet al., 2004;SALLES et al., 2005).

Porém, para explorar a grande potencialidade da Modelagem Qualitativa no processo de ensino e aprendizado de conceitos científicos, é necessário um período de adaptação à abordagem sistêmica adotada nos modelos e destreza para a operação do ambiente de modelagem.

A ausência de material educacional que introduza, de maneira didática, a Modelagem Qualitativa (MQ) para alunos e professores, é problema que dificulta o processo de incorporação desse recurso nos processos de ensino e na sala de aula (FELTRINI, 2009; RESENDE, 2010).

Somam-se a esse problema, a falta do domínio em LIBRAS pelos professores e a ausência de um regime de co-docência entre intérprete e professor regente, dificultando uma comunicação efetiva entre o professor e o aluno. Com isso o surdo não consegue compreender os conceitos trabalhados e o que está sendo discutido em sala (KELMAN \& TUXI, 2011).

Diante dessas questões, a presente pesquisa constatou a importância de promover, junto aos professores e aos alunos, uma forma de comunicação efetiva em que se utilize a LIBRAS e o RQ durante a mediação da aquisição ou aprimoramento do conhecimento. Junto a isso, há também uma necessidade de se promover a apropriação e uso das ferramentas de MQ, de uma forma mais simples, uma vez que, apesar de ser considerado um tema multidisciplinar, a maioria dos cursos de licenciatura não contempla a modelagem e o uso de ferramentas computacionais em suas disciplinas obrigatórias. Somam-se a essas dificuldades, a pequena disponibilidade de materiais didáticos em MQ, que possibilitem o uso de modelos qualitativos na educação científica de alunos surdos.

Nesse sentido, o software DynaLearn (BREDEWEG et al., 2013) é um ambiente de modelagem e de simulação de modelos que permite aos alunos interagirem de forma ativa no processo de construção de significados e doconhecimento, modelando, analisando resultados 
das simulações e propondo soluções para possíveis problemas encontrados (SALLES et al.,2012).

Um aspecto que favorece seu uso no ensino e na aprendizagem de conceitos por jovens estudantes do ensino fundamental e médio é a possibilidade de serem desenvolvidos modelos de diferentes níveis de complexidade, desde os mais simples, como mapas conceituais e diagramas de influência, até modelos que representam qualitativamente equações diferenciais ordinárias (BREDEWEG et al., 2013).

Como será discutido nesta Dissertação, o uso de modelos qualitativos do tipo diagramas de influência têm grande potencial para que alunos surdos tenham contato com uma representação sistêmica de fenômenos ecológicos e possam realizar exercícios voltados para o desenvolvimento do raciocínio hipotético-dedutivo explorando silogismos presentes em questões elaboradas a partir de um modelo sobre o tema "Desmatamento".

Sendo assim, o problema a ser pesquisado trata da dificuldade de comunicação no ensino de conceitos científicos de modo geral, e em Ecologia de modo particular, paraalunos surdos de Ensino Médio. Essa problemática tem sido reconhecida como fator que impede o desenvolvimento do raciocínio hipotético-dedutivo (SALLES et al., 2005; FELTRINI, 2009).

Para o presente trabalho, foi formulada a seguinte hipótese:

A Modelagem Qualitativa aplicada à educação científica de alunos surdos do Ensino Médio, em um nível mais simples e dentro de um contexto de educação bilíngue, oferece ferramenta efetiva para promover ensino aprendizagem de conceitos científicos, proporcionando ao aluno o desenvolvimento do raciocínio hipotético-dedutivo e tornando a dinâmica de sistemas compreensível para esses alunos.

A questão colocada na hipótese a ser pesquisada no trabalho foi elaborada seguindo uma estrutura na forma de pergunta (MARCONI et al, 2003), sendo aqui expressa como segue:

Quais as condições e materiais necessários para que modelos qualitativos relativamente simples, tais como os digramas de influência, possam ser trabalhados na forma de curso e ajudem efetivamente a desenvolver o raciocínio hipotético-dedutivo de alunos surdos, auxiliando a aquisição e a compreensão de conceitos científicos ecológicos?

Para a confirmação da hipótese de trabalho foram definidos os objetivos dessa pesquisa,em linhas gerais e específicas, sendo eles:

O Objetivo geral dessa pesquisa é apresentar proposta de curso de ensino de Ciências apoiada por modelos qualitativos para alunos surdos em um contexto bilíngue, LIBRAS/Português escrito. 
Os objetivos específicos são:

- Introduzir a Modelagem Qualitativa dentro de um contexto de Educação Bilíngue na Educação Científica de alunos surdos do Ensino Médio, de forma simples e atrativa, promovendo a aprendizagem de conceitos científicos e o desenvolvimento do raciocínio hipotético-dedutivo;

- Analisar as opiniões de professores (de alunos surdos e de ouvintes) sobre benefícios e dificuldades para introduzir a modelagem qualitativa na sala de aula;

- Verificar o potencial de modelos, do tipo diagrama de influência, para trabalhar com o raciocínio hipotético-dedutivo em alunos surdos;

- Avaliar material didático disponível para ensino de ciências apoiado por modelos qualitativos.

Apresente Dissertação está organizada da seguinte forma: na introdução são apresentados os principais referenciais teóricos abordados neste trabalho, assim como a justificativa, o problema a ser estudado, a hipótese e a proposta de pesquisa apresentada como objetivos. A seção 1 contém a revisão da literatura referente aos aspectos relevantes da educação de surdos. São citados alguns dos principais trabalhos já desenvolvidos e que utilizaram o Raciocínio Qualitativo na educação científica de alunos surdos. Uma revisão dos pressupostos básicos da Teoria Qualitativa dos Processos (FORBUS,1984), que fundamentam as atividades de modelagem desenvolvidase o software DynaLearn, plataforma de modelagem e simulação, são apresentados na seção 2. Na seção 3, será descrito todo o percurso metodológico para a realização de um curso para alunos surdos, detalhando: seu preparo e realização, a coleta de dados, o tratamento dos dados obtidos com a pesquisa e as análises estatísticas. Os resultados obtidos com os questionários, entrevistas, testes e a análise do material didático são apresentados na seção 4 . Na seção 5 , encontra-se a discussão sobre o trabalho desenvolvido e na seção 6,as considerações finais.Ao final, estão apresentados os referenciaisteóricos e bibliográficos e também os apêndices: documentos, materiais didáticos, testes, roteiros para a construção de modelos no software DynaLearn e outros materiais utilizados no presente trabalho e por fim a proposta de curso, que é o produto final dessa pesquisa e traz sugestões de atividades para a educação científica de alunos surdos. 


\section{EDUCAÇÃO DE SURDOS}

A educação de surdos possui várias peculiaridades que se devem ao contexto histórico e evolutivo desse processo. $\mathrm{O}$ surdo foi tratado como um deficiente que não tinha possibilidade de desenvolver sua cognição sem que houvesse a cura da perda auditiva e promovendo a comunicação pela via oral. Por isso, muitas abordagens metodológicas de ensino de surdos baseavam-se no processo de oralização como forma de promover a comunicação do surdo com seu interlocutor, que muitas vezes dominava apenas a língua majoritária do país em sua modalidade oral, isso acabava por não promover a comunicação por meio de uso de sinais, que é mais adequada à comunicação efetiva com esse público.

A comunicação oral e a leitura labial,desenvolvida no surdo por treinamento, não era eficaz para a maioria dos surdos oralizados. Já para os que conseguiam de alguma forma treinar a fala, acompreensão de significados que eram transmitidos no processo de ensino não ocorria com a eficiência esperada. Isso se devia principalmente à forma de comunicação que não atendia às reais características e necessidades desse grupo minoritário, que possui identidade comunicativa apropriada ao desenvolvimento de sua cognição, pois os significados eram repetidos sem nenhum contexto e não estimulavam o surdo a interagir com o que estava sendo transmitido (QUEIROZ\&KELMAN, 2009).

Sendo assim, o presente capítulo traz três seções: na primeira, é apresentado um breve contexto histórico da educação de surdos; na segunda seção, são expostas as principais abordagens metodológicas da educação de surdos; por fim,na terceira seção são discutidos aspectos relevantes para a inclusão do surdo no processo de ensino e aprendizagem, mostrando os principais trabalhos que utilizaram a MQ como forma de promover essa inclusão junto ao uso de uma abordagem bilíngue.

\subsection{Contexto histórico da educação de surdos}

No que se refere ao ensino de surdos, alguns momentos históricos ocorridos em várias partes do mundo marcaram a evolução dos processos de ensino e aprendizagem até se chegar na corrente Bilinguista que é seguida por esse trabalho. Esses momentos também refletem a 
maneira como o surdo era visto e tratado. Nesse sentido,Kelman(2005(2005),faz um levantamento de um histórico desse processo, como apresentado a seguir:

No fim do século XV, não havia escolas dedicadas ao ensino de alunos surdos e essa função era exercida por pessoas ouvintes.

- Giralamo Cardamo, na Itália, usava sinais e língua escrita;

- Pedro Ponce de Leon (1520-1584), monge beneditino, dava treinamento de voz, leitura labial e sinais para quatro surdos membros de uma família aristocrata na Espanha.

Nos séculos seguintes, na tentativa de compreender como deveria ocorrer o processo de ensino dos surdos, havia divergências quanto ao método mais adequado, sendo que alguns professores defendiam a priorização da língua falada, e outros defendiam a utilização da língua de sinais junto à fala.

No século XVII, destacaram-se:

- Juan Pablo Bonet, na Espanha, utilizava um método misto com o alfabeto manual junto a um treinamento da fala, seguindo a teoria e a prática do método de Ponce de Leon;

- Em 1770, Michel de I'Epée (1712-1789), cria a primeira escola de crianças surdas na França. Ele também cria os "sinais metódicos", que combinam os sinais com a gramática francesa;

- Jacob Rodrigues Pereira, médico português, considerado “desmutizador” por se dedicar a métodos oralistas e trabalhando na oralização de sua irmã surda,sofreu críticas de I'Epée por usar métodos oralistas;

- O pastor Samuel Heinicke (1723-1729), criou na Alemanha a primeira escola pública baseada no método oral, sendo auxiliado por Moritz Hill. A escola tinha apenas nove alunos.

No século XVIII, há um rompimento entre quem se dedicava a métodos oralistas e os que defendiam o uso da linguagem oral junto à língua escrita e à gestualizada. Isso leva a um aumento no número de escolas e de professores surdos trabalhando com a língua de sinais.

Porém, a visão médica ganha força depois da publicação do francês Jean Marc Gaspard Itard, Traité des maladies de I'oreille et de I'audition. Nessa publicação, Itard afirma que somente pela fala e pela restauração da audição que o surdo poderia aprender. 
Segundo as pesquisas de Tuxi (2009), Itard fazia experiências colocando sanguessugas no pescoço de surdos com a espectativa que o sangramento pudesse fazê-los voltar a ouvir.

- “Em 1815 e 1816, sai dos Estados Unidos Thomas Hopkins Gallaudet e visita escolas de surdos em catorze países diferentes. Depois vai a Paris, onde aprende o método manual usado por um ex aluno de I'Epée.";

- "Em 1817, Gallaudet, depois de levar o professor surdo Laurent Clerc para os Estados Unidos, funda a primeira escola americana para surdos, em Connecticut.”;

- "Em 1857, no dia 26 de setembro, D. Pedro II cria o Instituto de Surdos-Mudos no Brasil. O primeiro professor foi o francês Eduard Huet, o que explica a semelhança da Língua Brasileira de Sinais e a língua de sinais francesa.";

- "Em 1864, o filho de Gallaudet fundaem Washington a Universidade de Gallaudet, também só para surdos, sendo referência em pesquisas na educação de surdos no mundo até os dias de hoje.”;

- "Em 1870, ocorreu o Congreeso Internacional de Professores, em Milão. Alexandre Graham Bell, defensor da corrente oralista, influencia drasticamente a educação de surdos a partir de então. Esse congresso exclui os professores surdos de votar e determina a proibição do uso da língua de sinais nas escolas por alegar que essa destruía a capacidade de fala da criança surda.”.

(KELMAN, 2005)

A maior parte dos momentos históricos aqui citados refletem um fortalecimeto da abordagem metodológica oralista na educação de surdos. Porém, muitas experiências positivas utilizando sinais na comunicação de surdos e fracassos nos métodos oralistas fizeram com que essa corrente perdesse força dando espaço aobilinguismo, que é utilizado como abordagem de ensino no presente trabalho, por ser considerada mais adequada à comunicação efetiva com o aluno surdo e por tanto, capaz de promover um desenvolvimentocognitivopor meio da interação entre o que está sendo ensinado e o entendimento dos conceito de forma efetiva. 


\subsection{Principais abordagens metodológicas na educação de surdos}

Dentro do contexto histórico da educação de surdosexistiramvários conflitos entre os profissionais que se dedicaram a esse fim, por utilizarem métodos distintos e com enfoques diferentes no "tratamento" dessa problemática. Entre os principais métodos de ensino de surdos destacam-se o Oralismo, a Comunicação Total e o Bilinguismo (KELMAN, 2005).

Entre essas correntes de ensino, destacou-se por muito tempo o Oralismo, que tinha como principal base a priorizaçãodo uso da língua oral como forma de integrar o surdo dentro da comunidade ouvinte, cabendo ao professor ensinar a falar a língua natural dos pais desses surdos,sendo para tanto, necessária a intervenção de um fonoaudiólogo. Porém, nem todos os surdos desenvolviam uma fala compreensível, levando muitos professores a atrasar o ensino de conteúdos acadêmicos e, com isso, o surdo ficava com um déficit na leitura e na escrita. Tudo isso fazia o aluno surdo apresentar,além dos problemas já citados, um atraso na relação de idade/série e também, a não aquisição de conceitos que eram abordados em sala.

Mesmo com todas essas questões, o Oralismo é até hoje uma corrente com grande força, pois muitos pais (ouvintes) anseiam por ouvir seus filhos surdos poderem falar e se comunicar da mesma forma que eles o fazem. Para isso, muitos recorrem ao reestabelecimento de parte da audição ou pela valorização do resíduo auditivo de seus entes, com o uso de equipamentos, que vão desde aparelhos amplificadores sonoros de uso individual (AASI), a implantes cocleares. Esses aparelhos não garantem um sucesso pleno no reestabelecimento da audição e dependem muito do grau de surdez apresentado pelo indivíduo. A escala de comprometimento auditivo, segundo Martinho eSantos (2005), é dividida em:

\footnotetext{
"Leve- perda auditiva de 25 a 40 decibéis(dB);

Moderada- perda auditiva de 41 a 70 decibéis(dB);

Severa- perda auditiva de 71 a 90 decibéis(dB);

Profunda- perda auditiva acima de 90decibéis(dB).”
}

(MARTINHO eSANTOS, 2005)

Essa classificação ajuda a definir qual o melhor método a se utilizar para o reestabelecimento auditivo por meio do uso de aparelhos. Para as pessoas com grau de 
surdezleve e moderada, recomenda-se o uso de AASI, pois trata-se de um aparelho removível modelado de acordo com o canal auditivo de cada pessoa e que é capaz de amplificar os sons de forma a aproveitar o resíduo auditivo de seu usuário.

Já para os surdos com grau severo ou profundo, é indicada a cirurgia de implante coclear, por ser ineficaz o uso do AASI . Trata-se de uma cirurgia em que é implantado um dispositivo interno no osso mastóide que substitui a cóclea. Também há um componente externo deste dispositivo ligado ao implante, que serve como microfone e processador de fala. O som é então captado pelo dispositivo externo que manda os impulsos elétricos para o dispositivo interno, convertendo esses sinais em estímulos eletroquímicos que são mandados para o cérebro, onde ocorre o processamento da informação auditiva recebida (YAMADA e BEVILACQUA, 2005).

O uso de aparelhos pode restabelecer uma percepção auditiva no surdo, porém esses aparelhos possuem limitações de usos, pois podem ser danificados e sofrer desajustes ao ter contato com ondas magnéticas e com a água. Portanto, o surdo pode passar por situações em que não poderá usar um dispositivo que o auxilia a escutar, isso faz com que o mesmo possa ser excluído de processos sociais e de aprendizagem. Além disso, muitos surdos não se adaptam ao uso desses aparelhos e outros têm limitações que impedem o uso desses.

Diante dessas questões, o presente trabalho considera que o Oralismo, apesar de ter resultados positivos para alguns surdos, não reflete a real necessidade de inclusão dessa comunidade como um todo e portanto, não é a melhor corrente para se trabalhar com alunos surdos.

Já a corrente denominada Comunicação Total, ocorreu entre as décadas de 1960 e 1970. Essa filosofia de ensino adveio de estudos feitos nos Estados Unidos inicialmente por Willian Stokoe, em que se constatou que a língua de sinais americana possuía todas as características morfossintáticas, gramaticais e lexicais de qualquer outra língua, porém ela ocorria no plano visoespacial e não oral-auditivo (KELMAN, 2005).

Essa corrente era voltada à comunicação de forma geral e não para a aquisição de uma linguagem, como ocorria anteriormente. Pois, para ocorrer comunicação, deve haver uma relação entre interlocutores que dominem um determinado código, que é passado por meio de uma mensagem pelo emissor e que depois será decodificada pelo receptor, que pode, assim, interpretar e gerar respostas (LACERDA e MANTELATTO, 2000).

De fato, o domínio de um código em comum por interlocutores pode estabelecer uma comunicação efetiva, porém, por não haver um padrão definido na criação e execução desses códigos, muitas vezes a linguagem de sinais é ligada à língua oral e/ou escrita e é ai que está o 
grande problema dessa corrente. Afinal a gramática possui características próprias, assim como a língua de sinais e a fusão dessas duas línguas acaba por estabelecer conflitos no processamento da informação pelos surdos, pois, para Kelman (2005), "não se pode falar duas línguas ao mesmo tempo do ponto de vista neurológico."

Por isso, o presente trabalho defende a abordagem Bilinguista, que trata a Língua de Sinais como sendo a língua natural dos surdos, sendo portanto sua primeira língua (L1), enquanto que o Português escrito é adquirido durante os diversos tipos de contato com a escrita e ao longo do processo de proficiência da língua escrita na escola, sendo por isso, tratado como segunda língua ou L2.

Essas línguas são trabalhadas em separado e em momentos distintos, mas a sua junção pode acarretar o surgimento de uma confusão em que o surdo utiliza a estrutura da língua de sinais para escrever em Português, o que gera a "interlíngua" (KELMAN, 2005).

$\mathrm{O}$ uso de modelos dentro de um contexto Bilíngue, permite ao surdo compreender melhor os conceitos apresentados, pois estes são explicados na sua língua natural, permitindo ao cérebro processar a informação de acordo com seu desenvolvimento cognitivo e a bagagem de códigos advindos do aprendizado da língua de sinais. Esse aprendizado deve se dar nos momentos mais precoces da vida do surdo, afim de criar uma identidade surda e uma intimidade com os sinais.

Porém, ainda existem muitos desafios para melhorar essa corrente. Um deles passa pela ausência de sinais para representar conceitos científicos. O trabalho de Feltrini (2009), buscou contribuir com essa questão, produzindo um glossário em LIBRAS, de termos científicos ligados à Ecologia e a Modelagem Qualitativa. Esse glossário foi utilizado na presente pesquisa, o que auxiliou muito o desenvolvimento das aulas propostas, que eram totalmente ministradas em LIBRAS.

\subsection{Inclusão de surdos e trabalhos relacionados que utilizam MQ}

Quando se fala de educação de surdos, deve-se primeiramente compreender os princípios teóricos do processo de inclusão, sendo aqui tratada como um processo histórico e culturalmente sensível. 
Coelho (2010) trata de princípios teóricos, questões e desafios em relação à inclusão escolar. A autora buscou interligar questões históricas envolvendo o conceito de deficiência com as questões históricas dos processos de inclusão de grupos, chamados de minorias excluídas, mostrando uma dicotomização tradicional entre os aspectos individual e social.Tal segregação acaba afetando as relações que o individuo tem com o meio social no qual está inserido, podendo torná-lo subjugado dentro dessa relação e não permitindo que desenvolva capacidades e participe de decisões que o afetam. Como a própria autora trata, o conceito de “deficiência",enquanto historicamente é compreendidocomo um problema individual, impede que haja um processo de inclusão que seja compreendido como um processo de transformação social.

Dentro desse contexto, para que ocorra um verdadeiro processo de inclusão, há necessidade de ajustamento entre o individual e o social, de forma a se ter uma unidade dessas concepções para melhor análise e ação. Esses ajustes dependem da opção teórica que apoia os profissionais que trabalham diretamente com esse público. Afinal, todos têm identidades próprias, distintas umas das outras, mas se apoiam em teorias com as quais melhor se identificam.

Ainda para Coelho (2010), as abordagens teóricas de Vigotski (1998)e de González Rey (2003), seriam as que melhor representam os aspectos relevantes dentro de um processo de inclusão, sendo elas: a abordagem teórica dentro da perspectiva histórico-cultural de Vigotski (1991),que se baseia nos princípios da relação entre a relação da linguagem/fala/pensamento e aspectos do desenvolvimento atípico- "DEFECTOLOGIA", e que propõe uma compreensão dialética entre o biológico e o social; e a mais contemporânea, que é a abordagem teórica da subjetividade na perspectiva histórico-cultural de González Rey (2003), a qual permite estabelecer uma relação de continuidade entre a abordagem anteriormente citada, porém soma a essa a subjetividade e as emoções. Portanto, o indivíduo não é visto apenas como um fornecedor de respostas, mas trata-se de um sujeito ativo e participativo no processo de construção do conhecimento.

Para Vigotski (1998) a compreensão das palavras se dá quando o indivíduo é capaz de generalizar, relacionando suas experiências com as de seu interlocutor. Esse processo de generalização da palavra só ocorre quando há o encontro com o outro social e assim o desenvolvimento cognitivo deixa de ser apenas um resultado e passa a ser percebido como um processo ligado às vivências do indivíduo.

Na tentativa de homogeneizar os grupos educacionais, buscou-se ao longo da história rotular os indivíduos, sejam por apresentarem destaque em algo que se julgava como 
qualidade para a maioria, ou por "estigma" da pessoa que apresentava alguma característica atípica dos ditos "normais".

Pensar em inclusão deve, portanto, remeter à "EQUIDADE" em todos os seus aspectos, pois como na abordagem histórico-cultural de Vigotski (1998), leva a repensar a forma de ver o outro. A inclusão e o respeito à diversidade levam a ver uma pessoa com alguma atipicidade não como um deficiente, mas como um sujeito capaz de participar da sociedade de forma integral, desde que oferecidas as condições necessárias, muitas vezes compensatórias, para que isso ocorra de fato.

Dessa forma e assim como no trabalho de Feltrini (2009), esta pesquisa está pautada em uma abordagem sócio-antropológica (QUADROS, 2007). Portanto, trata o surdo não como um deficiente, mas sim como membro de uma comunidade linguística minoritária, que se comunica por meio da LIBRAS (Linguagem Brasileira de Sinais) como sua primeira língua, ou seja, sua língua natural, e o Português escrito é tratado como sua segunda língua.

O trabalho apresentado por Feltrini \&Gauche (2007) no VI ENPEC (Encontro Nacional de Pesquisas em Educação em Ciências), utilizando-se das premissas acima referidas, sugeriu pressupostos importantes para reorientar o ensino de alunos surdos, sendo eles: a LIBRAS deve ser a língua de instrução na escola; o professor deve ser mediador do conhecimento, não fornecendo respostas prontas; o conteúdo tem que ser trabalhado possibilitando o oferecimento do conhecimento científico em sua totalidade, ou seja, não deve omitir informações por achar complexo o seu entendimento, pois os alunos surdos devem ser tratados como indivíduos com plena capacidade cognitiva, e que eventual limitação na compreensão do que está sendo ensinado deve-se principalmente às dificuldades enfrentadas na forma de comunicação entre o mediador e os surdos; utilizar de uma metodologia bilíngue em que a LIBRAS é a primeira língua e o português escrito como metodologia de ensino de segunda língua; os recursos didáticos devem ser adequados à pedagogia visual explorando as habilidades visuais desses alunos e também bilíngue, o que apropria as especificidades linguísticas dos surdos. Esses pressupostos devem ser considerados em sua totalidade, de maneira que o professor que pretende trabalhar com alunos surdos os contemplem, para assim ter um melhor resultado no processo de ensino/aprendizagem.

Por isso, o curso ofertado aos alunos surdos na presente pesquisa foi desenvolvido utilizando-se do MQ de forma adaptada, por meio do uso de imagens associadas ao modelo do desmatamento e também, utiliza um glossário desenvolvido na pesquisa de Feltrini (2009), pois os sinais criados e validados junto à comunidade surda nos fornecem um vocabulário técnico adequado à comunicação e o entendimento de conceitos científicos aqui trabalhados. 
É importante destacar também que o ensino de surdos possui várias particularidades que levam a exigências específicas desta modalidade de ensino, de forma a suprir vários problemas, que vão desde o despreparo dos professores, àfalta de recursos tecnológicos e de materiais didáticos apropriados ao apoio deste processo. Diante dessas dificuldades, torna-se necessário que o professor mantenha uma comunicação efetiva com o aluno. Portanto, os dois devem conhecer e se comunicar na mesma língua, para que, a partir daí, o aluno possa interagir com que o professor está mediando e assim, compreender, interpretar e formular suas respostas e possíveis soluções (Carvalho, 2004). Para isso, o professor deve dominar a LIBRAS ou trabalhar em uma modalidade de co-docência com o intérprete, como apresentado no trabalho de Kelman e Tuxi (2011), em que o professor e o intérprete participam de todo o processo de elaboração e execução da aula. Isso possibilita ao aluno compreender melhor o que está sendo trabalhado, pois o intérprete não atua somente como um mediador da comunicação, mas sim, como um professor, pois ao tomar conhecimento do que está sendo trabalhado, ele pode mediar a comunicação de maneira mais adequada, auxiliando o professor na mediação e na explicaçãodos conceitos para os alunos surdos.Afinal, ambosdevem conhecer os conceitos científicos com os quaisse pretende trabalhar, mostrando-se preparados, para então, formar estratégias que utilizem recursos visuais e que contemplem uma abordagem bilíngue, de maneira a conseguir êxito no processo de ensino aprendizagem.

No entanto, entender a dinâmica dos sistemas é fundamental para a compreensão de muitos conceitos científicos, como demonstrado em trabalhos anteriores (SALLES et al., 2004;SALLES et al., 2005; FELTRINI, 2009; RESENDE, 2010). Para alunos surdos, esse entendimento é ainda mais complexo, visto o grande déficit acadêmico, que se deve muitas vezes, por falta de professores capazes de promover uma mediação adequada em que se faça presente uma educação científica bilíngue (LIBRAS - Português escrito) e ferramentas didáticas adequadas que explorem aspectos visuais da informação auxiliando a melhor compreensão de conceitos por surdos (SALLES et al., 2004; SALLES et al., 2005; FELTRINI, 2009; RESENDE, 2010; KELMAN e TUXI, 2011).

Muitas vezes, o auxílio de intérpretes pode ajudar ao professor que não conhece a Linguagem de Sinais a mediar o aprendizado de alunos surdos. Porém, a simples participação do intérprete não garante que esse processo ocorra de fato. Em muitas situações, a mediação não se dá de forma correta, por não haver sintonia entre o professor e o intérprete. Os mesmos deveriam atuar dentro de uma perspectiva de co-docência, segundo Kelman e Tuxi (2011), pois havendo sintonia entre eles,na mediação do processo de ensino aprendizagem, poderiam sercriadas condições favoráveis para o desenvolvimento e/ou aplicação de novas técnicas, 
materiais e ferramentas didáticas adequadas para esses alunos, que aproveitassemmelhor os sistemas compensatórios desenvolvidos por cada aluno. Entende-se por sistemas compensatórios os mecanismos de superação de dificuldades provenientes da deficiência, produzido por meio das relações sociais e culturais (VIGOTSKI,1998). Para o surdo, é normalmente o sistema visual, produzido por meio de relações sociais e culturais, que se torna compensatório à deficiência auditiva.

Como esse trabalho explorou o uso de imagens associadas a conceitos em Ecologia, o enfoque visual dos modelos, unido a essa abordagem, possibilita criar ferramenta adequada às necessidades do aluno surdo, explorando de forma atrativa o seu sistema compensatório. Porém, ainda há uma grande dificuldade em desenvolver e aprimorar o Português em sua modalidade escrita, junto aos alunos surdos.

Trabalho como o de Silva et al. (2003), já havia detectado a grande dificuldade para o surdo se apropriar da língua escrita, o que dificultaa sua inclusão, comunicação e participação de processos avaliativos.

Em Salles et al. (2004), também foi avaliada a capacidade dos alunos se apropriarem da escrita do português.ORQ como metodologia baseada no uso de modelos de simulação, juntoà criação de textos sobre o entendimento da dinâmica do sistema representado nos modelos, mostrou ser ferramenta útil no desenvolvimento do raciocínio e da escrita de alunos surdos. Esse trabalho analisou os resultados pautando-se na Teoria da Relevância (SPERBERe WILSON, 1995), que avalia a capacidade de o aluno fazer inferências por meio de raciocínio hipotético e formular conclusões "não triviais". Para isso, o aluno utiliza-se de pressupostos $^{1}$ contidos nos modelos e representados na forma de afirmativas e ao se eliminar algumas informações e baseando-se nesses pressupostos o aluno consegue dar respostas acertivas a respeito do que está sendo representado de forma indireta, ou seja ele é capaz de dar respostas não triviais. Já as respostas triviais, devem-se a uma adição de informação para se poder chegar a uma resposta, o que não demonstraria a capacidade de abstração nem a potencialidade de se resolver situações problemas por meio de silogismos. Essa pesquisa também apresentou resultados positivos na elaboração de textos escritos em português pelos surdos, sendo esses textos avaliados da mesma forma.

Posteriormente, Salles et al. (2007) confirmaram esses resultados e deram aporte teórico a questões referentes aos aspectos linguísticos examinados nos textos coletados nos

1 “Um Pressuposto constitui um conjunto de conceitos ao qual se aplicam regras dedutivas e o dispositivo dedutivo se baseia nas propriedades semânticas depreendidas de pressupostos, ampliando a representação do mundo" (FELTRINI, 2009). 
estudos de Salles et al. (2004) e apresentaram conclusões favoráveis ao uso de modelos na educação científica de surdos, por darem suporte ao desenvolvimento do raciocínio inferencial, modificando a representação do mundo e, desse modo, promovendo a melhor compreensão do significado dasinformações e fazendo com que o aluno surdo assimile melhor os conceitos e produza enunciados mais relevantes, demonstrando assim o efeito cognitivo do tratamento (FELTRINI, 2009).

A utilização do RQ, em uma abordagem que o aluno possa adquirir e aprimorar conceitos, possibilita uma construção do conhecimento de forma mais sólida. O uso de modelos qualitativos de simulação permite ao surdo desenvolver uma aprendizagem significativa, sendo esta caracterizada pela interação entre conhecimento novo e o conhecimento prévio do aluno. Processo este que é não literal e não pode ser arbitrário, no qual o conhecimento novo adquire significado e o conhecimento prévio fica mais rico, diferenciado e mais elaborado. Desse modo,o conhecimento passa a ter maior estabilidade e solidez (MOREIRA, 1999), possibilitando ao surdo pensar, abstrair e formular respostas como soluções a problemas que passam a ter maior intimidade. Essa intimidade também passa a ocorrer com termos e no entendimento de problemas que antes passavam despercebidos. Nesse sentido, o aluno passa a dar uma variedade de respostas, permitindo dar contribuição com característicaspróprias dele (GERIR, 2003). Essa forma de ensino permite ao aluno testar seu aprendizado, em que ele reconstrói seus conceitos a cada etapa, relacionando o conhecimento novo com os pré existentes em sua estrutura cognitiva e a partir daí, pode transformar conceitos em proposições (MATOS, 2009). 
O Raciocínio Qualitativo é uma área de pesquisa e desenvolvimento tecnológico da Inteligência Artificial que se dedica representar fenômenos físicos com base em conhecimentos incompletos, isto é, sobre os quais não existem conhecimentos quantificados ou, se existem, referem-se a partes do fenômeno. Desse modo, ferramentas baseadas no RQ podem representar conhecimentos que não dispõe de fundamentação teórica e valores não precisos para as variáveis representadas (WELD \& de KLEER, 1990).

Nesta seção, são apresentados elementos fundamentais da Teoria Qualitativa dos Processos - TQP - (FORBUS, 1984) e a 'bancada de modelagem' DynaLearn, na qual são construídos modelos qualitativos de acordo com a TQP.

\subsection{Pressupostos básicos da Teoria Qualitativa dos Processos}

Conforme Explica Salles (2004), a Teoria Qualitativa dos Processos (FORBUS, 1984) assume como pedra fundamental a noção de que processos são as principais causas de mudanças nos sistema, pois afetam diretamente certas quantidades, que propagamos efeitos ao longo do tempo para outras partes do sistema modelado. Além disso, preconiza que as relações de causalidade sejam explicitamente expressas no modelo, e sirvam de base para explicar e para prever o comportamento de um sistema. Dois elementos de modelagem são utilizados para representar causalidade: as influências diretas, modelados por I, que podem ser positivas ou negativas, e representamos efeitos diretos do processo e sempre são ativadas por meio de uma taxa; e as proporcionalidades qualitativas, modeladas por $\mathrm{P}$, que também podem ser positivas e negativas, demonstram como os efeitos do processo se propagam ao longo do sistema, sendo chamadas de influências indiretas (FORBUS, 1984).

O uso desses elementos básicos da modelagem qualitativa fundada na TQP pode ser ilustrado na forma do seguinte modelo verbal: considere-se um sistema formado por uma cidade, um rio e a atmosfera, de modo que os esgotos produzidos na cidade são emitidos para dentro do rio, causando a poluição das águas, a qual, por sua vez, é percebida pelo mau cheiro na atmosfera. Nessa situação, cai o preço de alguns imóveis na cidade. 
Nesse trecho, identifica-se um processo (emissão de esgotos) que tem dois efeitos, a poluição da água e o mau cheiro. Esse processo se dá a uma "velocidade", representada por uma 'taxa de emissão' de esgotos, que pode ser medida, por exemplo, em L/h. Desse modo, a quantidade de poluentes emitidos (em litros) para o rio depois de certo tempo, pode ser calculado a partir do valor da 'taxa'. Pode-se dizer ainda que, apesar da dificuldade em realizar medidas dessa quantidade, o mau cheiro exalado do rio é proporcional ao volume de poluentes jogados no rio.Essa situação pode ser modelada como segue:

I+(quantidade de poluentes, taxa de emissão)

$\mathrm{P}+$ (mau cheiro, quantidade de poluentes)

$\mathrm{P}-($ preço de imóveis, mau cheiro)

A relação de causalidade envolvida nesses eventos pode ser representada diagramaticamente como segue:

taxa de emissão $\rightarrow$ quantidade de poluentes $\rightarrow$ mau cheiro $\rightarrow$ preço de imóveis.

\subsection{Raciocínio Qualitativo e DynaLearn}

O softwareDynaLearn (BREDEWEGet al., 2013) foi desenvolvido pelo Projeto DynaLearn, parcialmente financiado pela Comissão das Comunidades Européias entre 20092012, que contou com a participação de pesquisadores de vários países, entre eles o Brasil, representado pela Universidade de Brasília.

O Projetouniu esforços de várias áreas do conhecimento e produziu um software que combina três abordagens tecnológicas. Essas abordagens já haviam sido testadas, porém nunca foram combinadas. Alguns recursos que possibilitavam realizar as abordagens distintas, que serão citadas logo à frente, eram feitas com o uso de mais de um software, entre eles estava o GARP3 (BREDEWEGet al., 2006), antecessor do DynaLearn.

As abordagens tecnológicas combinadas no softwaresão: a modelagem conceitual baseada em raciocínio qualitativo; o uso de mapeamento de ontologias definindo e classificando os conhecimentos representados nos modelos qualitativos; e o uso de agentes virtuais, personagens que aparecem na tela do software e que interagem, de maneira lúdica, com o modelador, ou com o usuário. 
A modelagem conceitual qualitativa, baseada na TQP, pode ser feita em seis níveis de complexidade, chamados Espaços de Aprendizagem (em inglês, Learning Spaces)- LS. Esses níveis de modelagem são descritos abaixo:

- $\quad$ LS1 = mapa conceitual. É um nível de modelagem que resulta em um diagrama em que conceitos (nós) são unidos por meio de linhas ou setas (arcos), que em conjunto e de maneira hierarquizada, descrevem conceitos complexos. São muito conhecidos e tem sido usados para planejamento, execução e avaliação em atividades educacionais. Entretanto, não é possível fazer simulações com esses modelos, que servem principalmente para organizar e descrever a estrutura do sistema com palavras (ou expressões matemáticas), sem contudo, usar elementos de modelagem.

- $\quad$ LS2 = modelo causal básico. Permite criar um diagrama de influências. Neste nível é possível inserir 'entidades', 'quantidades', 'derivadas', 'configurações', que são elementos da modelagem em .Trata-se do nível mais simples de modelagem, capaz de gerar simulações que indicam a variação das derivadas (em termos de 'crescendo', 'estável', 'diminuindo') das quantidades de cada objeto (entidade)que constitui o sistema. Nesses modelos não são representadas as influências diretas (I) e as proporcionalidades qualitativas (P), típicas da TQP. A causalidade é simplificada e representada apenas por setas que mostram, com sinais positivo (+) e negativo (-), o tipo de influência que uma quantidade exerce sobre outra.

As figuras abaixo mostram o modelo verbal descrito na seção 3.1. A Figura (a) mostra o modelo LS2, contendo três entidades (Cidade, Rio e Atmosfera) unidas pelas configurações 'envolve' e 'ao lado de', com as respectivas quantidades. A Figura (b) mostra uma simulação com o modelo, em que a situação inicial era a de redução dos esgotos lançados no rio e seus efeitos sobre as demais quantidades. Com base nas relações de causalidade, a valorização dos imóveis é explicada pelo controle sobre os esgotos.

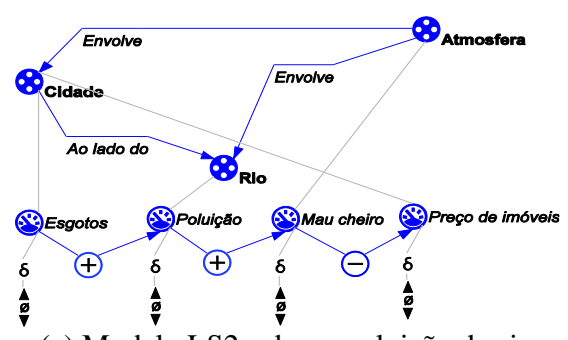

(a) Modelo LS2 sobre a poluição do rio

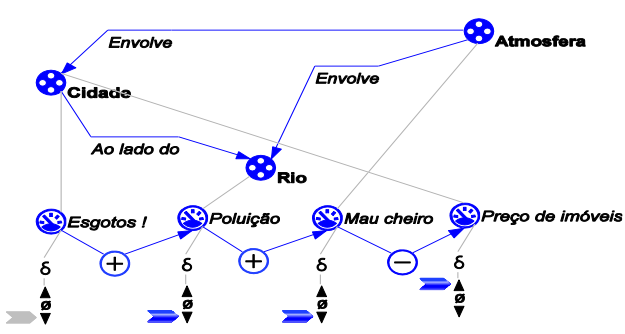

(b) Simulação com diminuição dos esgotos

Figura 1- Modelo e simulação "Poluição Rio"

(Fonte: imagem gerada no software DynaLearn) 
- $\quad$ LS3 = modelo causal básico com grafos de estados. Este nível é similar ao LS2, exceto pelo fato de que o valor das quantidades pode ter, além da derivada, a magnitude, que representa o 'tamanho' da variável. Por exemplo, o mau cheiro do rio pode assumir os valores (qualitativos) contidos no conjunto \{fraco, médio, forte\}, em que 'fraco' e 'forte' são intervalos de valores (numéricos) e 'médio' corresponde a um ponto. Neste caso, a simulaçãose torna mais rica em conteúdos, na medida em que pode produzir, caso a quantidade 'Mau cheiro' esteja crescendo ao longo do tempo, três estados:

$\langle$ fraco, crescendo $>\rightarrow<$ médio, crescendo $>\rightarrow\langle$ forte, crescendo $\rangle$

- $\quad$ LS4 = modelo com diferenciação das relações de causalidade. Neste nível de modelagem, além de serem utilizados todos os elementos de modelagem encontrados em LS3, as relações de causalidade podem ser representadas de duas formas: influências diretas (I) e proporcionalidades qualitativas $(\mathrm{P})$. Desse modo, é possível identificar processos e suas consequências e, aplicando-se os princípios da TQP, identificar onde se iniciam e para onde se propagam as mudanças observadas no comportamento do sistema.

- $\quad$ LS5 = modelo com conhecimento condicional. Tem como objetivo tornar mais refinada a compreensão de aspectos condicionais envolvidos no comportamento do sistema. Além de utilizar todos os elementos de modelagem de LS4, é possível representar condições para que certos fenômenos ocorram, tais como a ativação ou desativação de um processo ou de uma influência indireta (proporcionalidade). Por exemplo, é possível estabelecer que o preço dos imóveis citados acima só começa a desvalorizar quando 'Mau cheiro' atinge o valor forte, ou que a valorização começa quando o valor de 'Mau cheiro' se torna igual menor ou que 'médio'.

- $\quad$ LS6 = modelo genérico e reutilizável. Este é o nível de maior complexidade. Nele, são utilizados todos os elementos de LS5, mas a forma de representar conhecimentos é diferente, no sentido de que 'modelos' são coleções de partes independentes, chamadas 'fragmentos de modelo'. No exemplo descrito nesta seção, podem ser representados em fragmentos de modelos, o processo emissão de poluentes, a situação do rio, a situação da atmosfera, o preço dos imóveis e as condições para que o mau cheiro influencie o preço dos imóveis. Para que as simulações possam ser iniciadas, são necessários 'cenários', a representação de situações específicas. Por exemplo, um cenário poderia gerar uma simulação para mostrar apenas o processo e sua influencia direta sobre o rio. Outro cenário produziria uma simulação envolvendo o processo e os efeitos na atmosfera. Um terceiro cenário poderia mostrar os efeitos sobre o preço dos imóveis. Como se pode depreender desta breve apresentação, uma biblioteca de fragmentos de modelo e cenários pode conter muitos 
conhecimentos, muitas vezes complementares ou mesmo conflitantes, o que confere grande flexibilidade e capacidade de representação ao modelador e ao usuário de modelos, por exemplo, em uma situação educacional.

Neste trabalho serão utilizados apenas modelos representados em LS2. 


\section{3- PERCURSO METODOLÓGICO}

Diante do que foi exposto, o presente trabalho apresenta uma proposta de uso modelos qualitativos, construídos no nível LS2, no ensino de conceitos em Ecologia para alunos surdos.

Para isso, essa pesquisa consistiu na realização de atividades com alunos surdos do Ensino Médio de uma escola pública do Distrito Federal, com o apoio de professores/intérpretes, em formato deestudo de caso (GIL, 2002; YIN, 2005), sendo investigado e trabalhado o raciocínio dedutivo dos alunos utilizando modelos construídos no nível LS2. Para essas atividades foram confeccionados e utilizados materiais didáticos apropriados e adaptados como: textos, diagramas, modelos, imagens, entre outros, que constituíram um curso-piloto. Também foram colhidas as impressões que os professores/intérpretes tiveram sobre o curso, o material didático, o software utilizado e as perspectivas do uso dessa ferramenta na educação cientifica de alunos surdos. Por fim,são apresentadasuma avaliação do uso do material instrucional e uma proposta de sugestões de melhoria para o uso didático.

Nesse curso, também foram desenvolvidas atividades para que ocorresse a apropriação dos fundamentos da modelagem qualitativa e de como manusear o softwareDynaLearnno nível LS2. A fim de alcançar esses objetivos, foram utilizados textos e modelos preparados para o Manual Instrucional "Modelos Qualitativos para o ensino de Ciências de alunos surdos do Ensino Médio" (SALLES et al., 2013), produzido pelo Projeto Laboratório de Pedagogia Visual para a Educação bilíngue de surdos Libras/Português (LAPEVI²). Esse projeto buscou explorar o uso de temas do currículo de Ciências no aprendizado do Português escrito, como segunda língua para alunos surdos, trabalhando os conceitos científicos de forma interdisciplinar e explorando ao máximo a riqueza visual dos conceitos abordados, de forma a fornecer ao aluno surdo uma aprendizagem atrativa, participativa e adequada à sua necessidade, produzindo materiais didáticos com uma abordagem pedagógica visual e que explorasse os conceitos científicos juntamente com a expressão da linguagem escrita ou sinalizada.

${ }^{2}$ LAPEVI - Laboratório de Pedagogia Visualé um produto do Projeto“Laboratório de Pedagogia Visual para a Educação Bilingue de Surdos - Libras/Português" financiado por meio de Convenio entre o Ministério da Ciência, Tecnologia e Inovação e a Universidade de Brasília (ação 8976-MCT-Processo 01200.004623/2010-48), e conduzido por Professores do Instituto de Letras (Departamento de Linguística, Português e Línguas Clássicas) e Instituto de Ciências Biológicas (Núcleo de Educação Científica do IB - NECBio). Outro produto do Projeto LAPEVI é o manuscrito referido nesta Dissertação como Salles et al. (2013). 
Do 'Manual Instrucional' foram transcritos textos e modelos utilizados para a elaboração de material didático com os objetivos de apresentar a modelagem qualitativa e introduzir o softwareDynaLearn; afirmações com o formato "SE... ENTÃO...” , frases que constituíam silogismos e exercícios voltados para o raciocínio dedutivo dos alunos; ilustrações para apresentações em Power Point; e um modelo qualitativo para estudo detalhado.

O conteúdo deste capítulo é apresentado emtrês seções: a primeira é composta pela metodologia utilizada na pesquisa como proposto por Gil (2002), que contempla a delimitação da unidade-caso, a forma da coleta de dados, como foram selecionados, analisados e interpretados os dados, e por fim, um relatório apresentado nos resultados; na segunda seção. estão detalhadas as atividades desenvolvidas no curso ofertado aos alunos na forma de um quadro e, na terceira,é apresentada a forma como foi avaliado o 'Manual Instrucional'(SALLES et al., 2013), utilizado no curso.

\subsection{Metodologia - delimitação da unidade de caso, coleta e tratamento dos dados e relatório}

Esta pesquisa configura-seno formato deum estudo de caso (GIL, 2002;YIN, 2005), pois a metodologia descrita por ambos os autores converge na obtenção, tratamento e análise dos dados, buscando um rigor metodológico no tratamento dos dados empíricos observados e coletados.Os dados foram coletados por meio de: observações,questionários, entrevistas, análise de exercícios, e aplicação de pré e pós-testes abordando conhecimentos gerais sobre os efeitos do desmatamento.

Foram realizadas observações sobre o comportamento dos alunos, posteriormente discutidas com os professores para confirmação de resultados qualitativos. Também foram realizados questionários e entrevistas (BICUDO, 2006), para a coleta das impressões que os alunos, professores e intérpretes participantes do curso, tiveram acerca da Modelagem Qualitativa; do curso como um todo; do software DynaLearn; dos materiais didáticos; das atividades desenvolvidas durante o curso; e das possibilidades de uso desses recursos no ensino deCiências para alunos do Ensino Médio, em um contexto de inclusão de alunos com deficiência auditiva. 
No que se refere às entrevistas, de particular interesse para este trabalho, foram realizadasentrevistas tipo semi-estruturadas(MARCONI; LAKATOS, 2003), sendo direcionadas por uma seleção de perguntas previamente elaboradas, que permitiam uma organização flexível e ampliada dos questionamentos no decorrer da própria entrevista (FUJISAWA, 2000). Para isso, foi utilizado um gravador que permitiu aprimorar a compreensão da fala do entrevistado (SCHRAIBER, 1995), além de preservar o conteúdo original e aumentar a precisão dos dados coletados (PATTON, 1990; ROJAS, 1999). As entrevistas foram precedidas de uma orientação prévia aos entrevistados(FALCÃO eTÉNIES, 2000), seguidado preenchimento e assinatura dotermo de consentimento do uso das informações que seriam coletadasde todos os participantes.

Depois de coletados os dados, foram feitas as transcrições das entrevistas pelo próprio pesquisador/entrevistador, como proposto por (PRETTI eURBANO, 1988). Em seguida, foram eliminadas da transcrição as expressões como as palavras e comportamentos nãoverbais como proposto por Lage (2001).

Após a transcrição das informações, apesar de não ter sido feita a Análise de Conteúdo proposta por Bardin (1995)para a análise e tratamento dos dados coletados, pode-se,na leitura detalhada de todo o material transcrito, identificar palavras e conjuntos de palavras que tinham sentido para a pesquisa, e,buscando classificá-las em categorias semelhantes, levandose em conta aspectos semânticos dos dizeres (OLIVEIRAet al, 2003), ficou evidente uma categoria de dizeres sobre a utilização do RQ de uma forma interdisciplinar.

O material introdutório para a modelagem qualitativa utilizado foi o DVD instrucional desenvolvido por Feltrini (2009). Neste, são demonstradas as bases desse tipo de modelagem, e um passo-a-passo para a construção de modelos, com exercícios para treinamento. Além disso, o material é bilíngue LIBRAS - Português e traz um glossário em que os principais termos utilizados nos modelos qualitativos, definidos pela própria comunidade de surdos, são apresentados em língua de sinais.

Para a elaboração dos exercícios e dos pré e pós testes, foi utilizado um modelo qualitativo que tinha como objetivo demonstrar os efeitos do desmatamento sobre a biodiversidade, a erosão, os recursos hídricos e sobre as consequências econômicas decorrentes da perda da diversidade biológica, da produção de sedimentos e da falta de recursos hídricos. Esse modelo e alguns dos exercícios utilizados foram adaptados do Manual Instrucional "Modelos Qualitativos para o ensino de Ciências de alunos surdos do Ensino Médio"(SALLES et al., 2013), produzido no Projeto Laboratório de Pedagogia Visual para a Educação bilíngue de surdos Libras/Português (LAPEVI). 
Com o objetivo de verificar, por meio de análises estatísticas sobre os dados obtidos no pré e no pós testes, se o uso de modelos qualitativos contribuiu para melhorar o desempenho dos alunos na formulação de respostas que exigiam a capacidade de fazer inferências sobre relações de causa e efeito em fenômenos relacionados ao desmatamento, foram formuladas duas hipóteses (Siegel, 1977), a de nulidade $\left(\mathrm{H}_{0}\right)$, que indica não ter havido efeito significativo com o tratamento aplicado (uso de modelos), e a hipótese alternativa $\left(\mathrm{H}_{1}\right)$, que indica efeito significativo do tratamento no resultado final:

$\mathrm{H}_{0}$ : $\mathrm{O}$ uso de modelos qualitativos não teve influência estatisticamente significativa sobre o desempenho dos alunos em testes que exigiam a capacidade de fazer inferências;

$\mathrm{H}_{1}$ : $\mathrm{O}$ uso de modelos qualitativos teve influência estatisticamente significativa sobre o desempenho dos alunos em testes que exigiam a capacidade de fazer inferências.

Para a realização da análise estatística, foram feitos os seguintes testes:o teste paramétrico adotadofoi o testetde Student pareado (VIEIRA, 2008); e o teste não paramétrico escolhidofoi o teste de Wilcoxon pareado (CALLEGARI-JAQUES, 2003).

Os dados obtidos pelos pré e pós-testes permitiram combinar a análise qualitativa a uma quantitativa, de maneira a dar uma maior consistência àsconclusões deste trabalho.

\subsection{As atividades realizadas com os alunos e professores}

O curso-piloto foi realizado no período entre setembro e novembro de 2014. Foram realizados oito encontros presenciais com duração de duas horas, em média, cada um, totalizando aproximadamente 16 horas de curso. Importante observar que alguns dos trabalhos desenvolvidos para esta Dissertação foram compartilhados com um grupo de pesquisas do Departamento de Linguística, Português e Línguas Clássicas do Instituto de Letras, Universidade de Brasília, interessado nos textos produzidos pelos surdos no contexto dos estudos realizados com modelos qualitativos.

Com efeito, o grupo de estudos sobre o desenvolvimento da Língua Portuguesa escrita pelos surdos participou de dois encontros, para coletar dados. No segundo encontro, foi apresentado em LIBRAS um texto relacionado aos efeitos do desmatamento da floresta sobre 
população indígena, e posteriormente os alunos surdos desenvolveram uma redação sobre esse assunto. Finalmente, no oitavo encontro, a equipe apresentou outro texto relacionado o uso da floresta e a produção de energia, e os alunos fizeram uma redação sobre este tema.

Os resultados obtidos por esse grupo de estudos não serão tratados aqui.

O conjunto completo de atividades desenvolvidas com os alunos surdos e com os professores estão apresentadas na forma de um quadro.

Quadro 1- Atividades desenvolvidas no curso

\begin{tabular}{|c|c|c|c|}
\hline Encontro & Atividade realizada & Material utilizado & Atividade de avaliação \\
\hline 1 & $\begin{array}{l}\text { Apresentação da } \\
\text { modelagem } \\
\text { qualitativa e do } \\
\text { DynaLearn }\end{array}$ & $\begin{array}{l}\text { ATIVIDADE } 1 \\
\text { Modelo “Arvore e Sombra”; DVD } \\
\text { instrucional;Glossário em LIBRAS; } \\
\text { Apresentações em Power point com } \\
\text { ilustrações e modelos. }\end{array}$ & $\begin{array}{l}\text { Exercícios “SE ... ENTÃO ...”; } \\
\text { interpretação de modelos . }\end{array}$ \\
\hline 2 & $\begin{array}{l}\text { Aplicação dos Pré- } \\
\text { testes } \\
\text { Atividades no estudo } \\
\text { de linguística para } \\
\text { coleta de dados }\end{array}$ & $\begin{array}{l}\text { Pre-teste explorando a capacidade de } \\
\text { fazer inferências; } \\
\text { Início das atividades do grupo de estudos } \\
\text { sobre o português escrito, com } \\
\text { apresentação de um texto pelo professor } \\
\text { e realização de um exercício pelos alunos } \\
\text { surdos. }\end{array}$ & $\begin{array}{lrr}\text { Realização } & \text { de } & \text { exercícios } \\
\text { explorando } & \text { a } & \text { Língua } \\
\text { Portuguesa. } & & \\
\end{array}$ \\
\hline 3 & $\begin{array}{l}\text { Discussão de texto; } \\
\text { Avaliação: } \\
\text { elaboração de } \\
\text { redações. }\end{array}$ & $\begin{array}{l}\text { Apresentações em Power point e texto } \\
\text { sobre os índios Ka'apor. Continuação } \\
\text { das discussões sobre os efeitos do } \\
\text { desmatamento. } \\
\text { Alunos surdos elaboram uma redação } \\
\text { sobre desmatamento. }\end{array}$ & $\begin{array}{l}\text { Interpretação de texto e } \\
\text { elaboração de redação. }\end{array}$ \\
\hline 4 & $\begin{array}{l}\text { Silogismos } \\
\text { Modelos qualitativos }\end{array}$ & $\begin{array}{l}\text { ATIVIDADE } 2 \\
\text { Textos extraídos do Capítulo } 2 \text { e imagens } \\
\text { do Capítulo } 3 \text { do "Manual Instrucional' } \\
\text { com silogismos sobre os efeitos do } \\
\text { desmatamento sobre a vegetação de } \\
\text { Cerrado. } \\
\text { Uso de materiais contendo pedaços do } \\
\text { modelo "Desmatamento" (Capítulo } 3 \text { do } \\
\text { 'Manual Instrucional') para serem } \\
\text { associados a descrições textuais do } \\
\text { modelo mostrado. }\end{array}$ & $\begin{array}{l}\text { Exercícios sobre silogismos. } \\
\text { Exercícios envolvendo modelos } \\
\text { qualitativos muito simples, com } \\
\text { o objetivo de associar textos } \\
\text { com a representação na forma } \\
\text { de modelos qualitativos. }\end{array}$ \\
\hline 5 & $\begin{array}{l}\text { Raciocínio } \\
\text { Qualitativo }\end{array}$ & $\begin{array}{l}\text { ATIVIDADE } 3 \text { - parte } 1 \\
\text { Modelo "Desmatamento", extraído do } \\
\text { Capítulo } 3 \text { do 'Manual Instrucional' e } \\
\text { convertido para LS2; Computadores; } \\
\text { textos extraídos do Capítulo } 2 \text { do } \\
\text { 'Manual Instrucional' e apresentações } \\
\text { emPower pointcom ilustrações e } \\
\text { imagens de modelos. }\end{array}$ & $\begin{array}{l}\text { Exercícios "SE ... ENTÃO...”, } \\
\text { confecção de modelo no } \\
\text { computador e interpretação de } \\
\text { modelos e e imagens., } \\
\text { "...PORQUE...” e identificação } \\
\text { do tipo de influências ativas. }\end{array}$ \\
\hline
\end{tabular}




\begin{tabular}{|c|c|c|c|}
\hline 6 & $\begin{array}{l}\text { Raciocínio hipotético } \\
\text { dedutivo } \\
\text { Silogismos }\end{array}$ & $\begin{array}{l}\text { ATIVIDADE 3- parte } 2 \\
\text { Modelo "Desmatamento" extraído do } \\
\text { Capítulo } 3 \text { do 'Manual Instrucional' e } \\
\text { convertido para LS2. } \\
\text { Construção de um modelo semelhante ao } \\
\text { modelo "Desmatamento", abordando a } \\
\text { "Regeneração" da floresta. } \\
\text { A estrutura dos dois modelos é muito } \\
\text { semelhante, porém os efeitos das } \\
\text { influencias iniciais são opostas } \\
\text { (desmatamento e regeneração da } \\
\text { floresta). }\end{array}$ & $\begin{array}{l}\text { Interpretação de modelos e } \\
\text { exercício do tipo: "Se... } \\
\text { Então...", aumenta ou diminui e } \\
\text { indicação de influências } \\
\text { positivas(+) ou negativas (-). }\end{array}$ \\
\hline 7 & $\begin{array}{l}\text { Raciocínio } \\
\text { Qualitativo, } \\
\text { Raciocínio hipotético } \\
\text { dedutivo } \\
\text { Silogismos }\end{array}$ & $\begin{array}{l}\text { ATIVIDADE } 4 \\
\text { Trabalhos explorando } \\
\text { Modelos"Desmatamento" } \\
\text { "Regeneração", o que permitiu a } \\
\text { formulação de inferências mais } \\
\text { complexas a partir dos efeitos de perda e } \\
\text { da regeneração da floresta sobrea } \\
\text { estrutura comum aos dois modelos, }\end{array}$ & $\begin{array}{l}\text { Interpretação de modelos e } \\
\text { exercício do tipo: "Se... } \\
\text { Então...", Aumenta ou Diminui } \\
\text { e Indicação de (+) ou (-). }\end{array}$ \\
\hline 8 & $\begin{array}{l}\text { Atividades } r \text { de } \\
\text { avaliação: respostas } \\
\text { ao pós teste, e aos } \\
\text { questionários. } \\
\text { Coleta de dados para } \\
\text { o grupo de Língua } \\
\text { Portuguesa }\end{array}$ & $\begin{array}{l}\text { Pós testes; } \\
\text { Respostas aos questionários } \\
\text { O grupo de Língua Portuguesarealizou } \\
\text { um exercício com os alunos, e pediu que } \\
\text { eles fizessem uma redação. }\end{array}$ & $\begin{array}{l}\text { Exercício do tipo julgar (C) } \\
\text { para Certo, ou (E) para Errado, } \\
\text { nas afirmativas do tipo 'SE... } \\
\text { ENTÃO ...' “... PORQUE ...” e } \\
\text { as questões para completar com } \\
\text { 'AUMENTA' ou 'DIMINUI'. } \\
\text { Exercícios e redação para } \\
\text { estudos em Língua Portuguesa. }\end{array}$ \\
\hline
\end{tabular}

\subsection{Avaliação do 'Manual Instrucional'}

O Manual Instrucional(SALLES et al., 2013) utilizado na elaboração das atividades do curso foi avaliado nessa pesquisa pelo uso de questionário (MARCONI e LAKATOS, 2003) buscando verificar os seguintes tópicos: adequação aos estudantes, abordagem de raciocínio dedutivo, material para exercícios e uso dos modelos. Os alunos puderam deixar suas impressões sobre o curso, a modelagem e os materiais utilizados. Trata-se de um questionário já aplicado na pesquisa desenvolvida por Resende (2010) em diferente contexto, e utilizado novamente no presente trabalho com adaptações, por ser um material visualmente atraente, que atende melhor aos objetivos de se trabalhar com alunos surdos, os quais deveriam responder as questões de acordo com a legenda apresentada na página a seguir: 


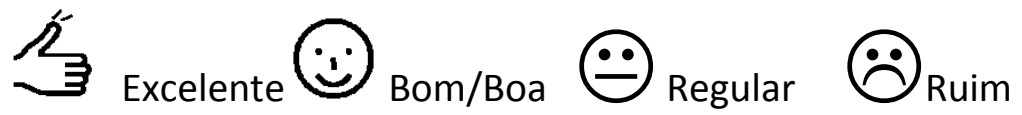

Também foram feitas observações (LAVILLE e DIONE, 2008) referentes utilização de materiais derivados deste Manual Instrucional como: imagens, textos, modelos e exercícios sendoque alguns deles sofreram algumas adaptações a fim de atenderem os objetivos do presente trabalho.

As opiniões e informações dos professores foram coletadas por meio de entrevistas (BICUDO, 2006). 


\section{4- RESULTADOS}

A turma formada para a realização do curso era constituída por alunos surdos, todos maiores de idade e que estavam cursando os $2 .^{\circ}$ e $3 .^{\circ}$ anos do Ensino Médio, nunca tiveram contato com Modelagem Qualitativa e todos eles dominavam bem a linguagem de sinais. De um total de 18 alunos que iniciaram o curso, apenas 12 participaram das atividades até o fim. Os alunos apresentavam características semelhantes em vários aspectos, sendo que,ao serem indagados sobre o grau de sua surdez, a maioria se considerava surdoprofundo e apenas dois alunosse consideraram surdos moderados, porém não apresentaram laudos sobre o grau de suas surdez. Na literatura, o surdo profundo é aquele com ausência da capacidade de ouvir, ou a incapacidade de ouvir sons abaixo de cerca de 95 decibéis. Já os surdos moderados são aqueles que possuem uma surdez média ou perda auditiva severa (COSTA, 2008).

“A surdez pode ser classificada segundo ao tipo de percepção dos sons:

- Perda Auditiva Severa- Perda tonal média entre 71 dB e 90 dB, há incapacidade de ouvir sons abaixo de cerca de 80 decibéis.

- Surdez média- Perda tonal média entre $41 \mathrm{~dB}$ e $70 \mathrm{~dB}$

- Surdez profunda- A palavra não é percebida. Apenas se ouvem os ruídos muito intensos. Perda tonal média entre $91 \mathrm{~dB}$ e $119 \mathrm{~dB}$.

- Surdez total - Perda média é de 120 dB. Também conhecida como Cofose ou surdez absoluta. Não se percebe som algum."

(COSTA, 2008)

Entre as características que os diferenciavam, as principais foram que:quatro alunos eram oralizados e dois deles apresentavam,além da surdez, outros comprometimentos.Porém, nenhuma dessas características distintas impediu ou limitou a aplicação das atividades, não havendo maiores necessidades de adequação, além das propostas no curso e do uso da LIBRAS.

Os professores que auxiliaram na interpretação das aulas foram, na sua totalidade, mulheres, com idades entre 40 e 50 anos e que atuam na rede pública de ensino há mais de 20 anos. Todas dominavam a Libras por trabalharem há mais de 10 anos com a educação de surdos. A formação acadêmica desse grupo de professoras era: História, Português, Libras, Física e uma mestra em Ensino de Ciências. Uma porcentagem de 50\% das professoras já havia tido contato com a Modelagem Qualitativa por meio de um curso realizado em outro 
momento na mesma escola. Grande parte dessas professoras atua como regente da disciplina correspondente àsua formação e também há aquelas que atuam como coordenadoras na escola.

Os resultados obtidos com o trabalho desenvolvido com o grupo de alunos auxiliados pelos professores serão apresentados nas seguintes seções: na seção 4.1, estão os resultados das atividades aplicadas aos alunos surdos sendo divididas em: quatro atividades, pré e pós testes,um questionário,os resultados obtidos com as análises estatísticas da comparação dos resultados entre o pré e pós-teste; na seção 4.2, encontram-se os resultados obtidos com a análise das entrevistas realizadas com os professores/intérpretes que auxiliaram no desenvolvimento das aulas; e na seção 4.3,estão os resultados obtidos com a análise do 'Material Instrucional'.

\subsection{Resultados das atividades aplicadas aos alunos surdos}

De fato, pode-se verificar que os resultados combinados apresentam uma crescente melhora no desempenho dos alunos ao longo do curso e a compreensão das relações de causalidade presentes nas atividades, evidenciadas pelas médias obtidas nos testes, apontando para resultados positivos no desenvolvimento do raciocínio dedutivo desses alunos.

\subsubsection{Resultado da Atividade 1}

A Atividade 1 foi realizada com o objetivo de demonstrar os elementos básicos da modelagem, por meio de um modelo que estabelecia as relações entre o crescimento de árvores em crescimento, o tamanho das sombras formadas por elas e a temperatura na superfície sombreada do solo.

Os testes aplicados mostraram alto número de acertos, representado por uma média de $76,4 \%$, obtida com os nove (9) alunos que realizaram a atividade. Esse resultado pode tersido distorcido por ter sido essa atividade realizada em casa, por poder ser resolvida com conhecimentos do cotidiano, ou porque alguns alunos podem ter contado com ajuda de 
terceiros. Entretanto, posteriormente verificou-se que os alunos que obtiveram um melhor desempenho ao longo do curso, foram os mesmos que resolveram a Atividade 1.

O resultado da primeira parte da tarefa, composta por questões que deveriam ser completadas com 'Aumenta' ou 'Diminui', tiveram um índice de acertos de 87,5\%, sendo que 5 dos 9 alunos que fizeram essa atividade acertaram todos os itens, enquanto outros 2 alunos erraram apenas 1 item dessa parte da tarefa.

A segunda parte dessa atividade, em que os alunos deveriam julgar 'Certo' ou 'Errado' para cada afirmativa do tipo 'SE...ENTÃO...', apresentou um resultado inferior ao da primeira parte, com uma média de acertos de 57,8\%, sendo que 3 alunos, acertaram todos os itens, enquanto apenas 1 aluno errou todos os itens desta parte.

As notas dos alunos ficaram divididas em categorias, como apresentado na tabela abaixo:

Tabela1: Frequências das notas dos alunos na Atividade1 $(\mathrm{n}=9)$

\begin{tabular}{c|c}
\hline Quantidade de alunos & Faixa de notas \\
\hline 2 & Igual a100\% \\
\hline 2 & Maior que $90 \%$ \\
\hline 3 & Entre $60 \%$ e $90 \%$ \\
\hline 2 & Inferior a $50 \%$ e igual a $46 \%$ \\
\hline
\end{tabular}

Os resultados dessa atividade foram positivos, permitindo inferir a boa capacidade dos alunos conseguirem fazer inferências e de responderem questões que exploram o raciocínio envolvido no uso de modelos no nível LS2, já que as questões dessa atividade exploravam apenas as relações de causalidade presentes em modelos simples, criados nesse nível.

Os itens que apresentaram um maior índice de respostas discordantes do gabarito foram os itens 12, 10 e 11 respectivamente, sendo que o item 12 foi respondido errado por seis alunos, portanto, apresentou um índice de respostas discordantes superior a 50\%. Já a questão 10, teve 4 alunos que responderam em desacordo, seguido pela questão 11, com três alunos respondendo em discordância ao gabarito, ou seja, a média de respostas em desacordo para esses dois itens foi inferior a $50 \%$.

Abaixo estão apresentadas as questões e os resultados obtidos em cada uma:

"12- ( ) A temperatura do solo diminui, PORQUE a sombra da árvore diminui.."

Este item foi o que teve um maior número de respostas em desacordo com o Gabarito, sendo que apenas três alunos acertaram. 


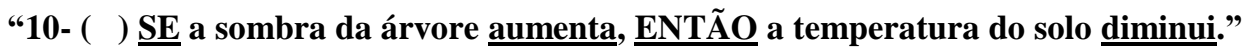

Cinco alunos acertaram e quatro alunos erraram.

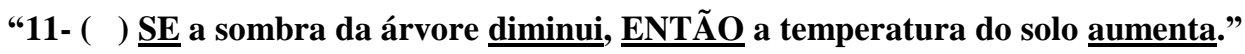

Seis alunos acertaram e três alunos erraram esse item.

Esses resultados podem ser explicados pelo acúmulo de "negações" expressas no modelo e nas perguntas formuladas, que se tornam mais complexas. As três questões tratam da relação entre a sombra da árvore e a temperatura da área de solo sombreado, expressa por uma relação 'negativa', tal que quando a sombra aumenta, a temperatura diminui. Assume-se que se a temperatura diminuir, a causa terá sido o aumento da área sombreada. As questões 11 e 10 , acertadas por cerca de $2 / 3$ dos adota a ordem direta da causalidade, perguntando pela consequência do crescimento da árvore. Na questão 12, a relação de causalidade é invertida, e o enunciado aparece como uma explicação. Além disso, resposta esperada é o aluno reconhecer que o enunciado é "falso".

\subsubsection{Resultados da Atividade 2}

A Atividade 2 tinha por objetivo associar o enunciado da relação entre causa e consequência, em, língua portuguesa, e a expressão dos elementos dessa relação diagramaticamente representados no modelo. Inicialmente, foram tratados os silogismos e, por meio de exercícios baseados em textos, foi introduzida a noção de causalidade. Posteriormente, foram apresentadas partes do modelo "Desmatamento", especificamente as que tratavam dos efeitos do desmatamento sobre os recursos hídricos (sedimentos nos reservatórios, usos da água, população sem água). Os alunos tinham de analisar essas partes de modelo e preencher lacunas com respostas curtas para as questões colocadas.

A inferência básica a ser realizada nos exercícios era interpretar as consequências de uma situação específica, em que a quantidade influenciadora estava aumentando, estável ou diminuindo, e seus efeitos sobre a quantidade influenciada, que poderia estar também respectivamente aumentando, estável ou diminuindo se a relação fosse mediada por uma 
influência positiva (+); ou a quantidade influenciada estaria diminuindo, estável ou aumentando, respectivamente, se a relação fosse mediada por uma influência negativa (-). Outra opção explorada nesse exercício foi pedir que o aluno identificasse se a influência era positiva ou negativa, dadas as condições das quantidades influenciadora e influenciada.

Participaram da realização dessa atividade um total de 13 alunos,sendo obtida uma média de 64,5\%, o que mostra uma evolução dos alunos na resolução de atividades que exploram inferências e o raciocínio hipotético-dedutivo em relação ao que foi desenvolvido na Atividade 1.

As médias das notas obtidas pelos alunos estão apresentadas na tabela a seguir:

Tabela2: Frequências das notas dos alunos na Atividade2 (n=13)

\begin{tabular}{c|c}
\hline Quantidade de alunos & Faixa de notas \\
\hline 3 & Igual a $94,4 \%$ \\
\hline 1 & Igual a $89 \%$ \\
\hline 1 & Igual a $78 \%$ \\
\hline 2 & Igual a 55,5\% \\
\hline 2 & Igual a 50\% \\
\hline 4 & Inferior a 50\% e igual a $44,4 \%$ \\
\hline
\end{tabular}

Portanto, 69,23\% dos alunos alcançaram notas iguais ou superiores a $50 \%$ de aproveitamento, sendo que, desse total, aproximadamente $40 \%$ obtiveram notas muito boas, acima de $77 \%$ de aproveitamento.

As maiores dificuldades foram observadas na resolução das últimas questões, em que muitos alunos, em lugar de responderem 'Positivo' ou 'Negativo' para o sinal da influência, responderam 'Aumenta' ou 'Diminui'. Isso pode ter ocorrido por um comando da questão não ter sido elaborado de forma clara, ou pela não compreensão do que estava sendo proposto por parte do aluno. O fato é que as afirmativas referentes aos modelos 5, 7, 8, 9 e 10 apresentaram uma porcentagem de erros elevados, fato também observado na afirmativa do modelo 3. 
Abaixo estão apresentados os resultados das porcentagens de respostas em acordo e em desacordo com o gabarito, na 'Atividade 2'.

"Sobre os modelos abaixo, complete-as lacunas com AUMENTA, DIMINUI ou ESTABILIZA:"

Modelo 1

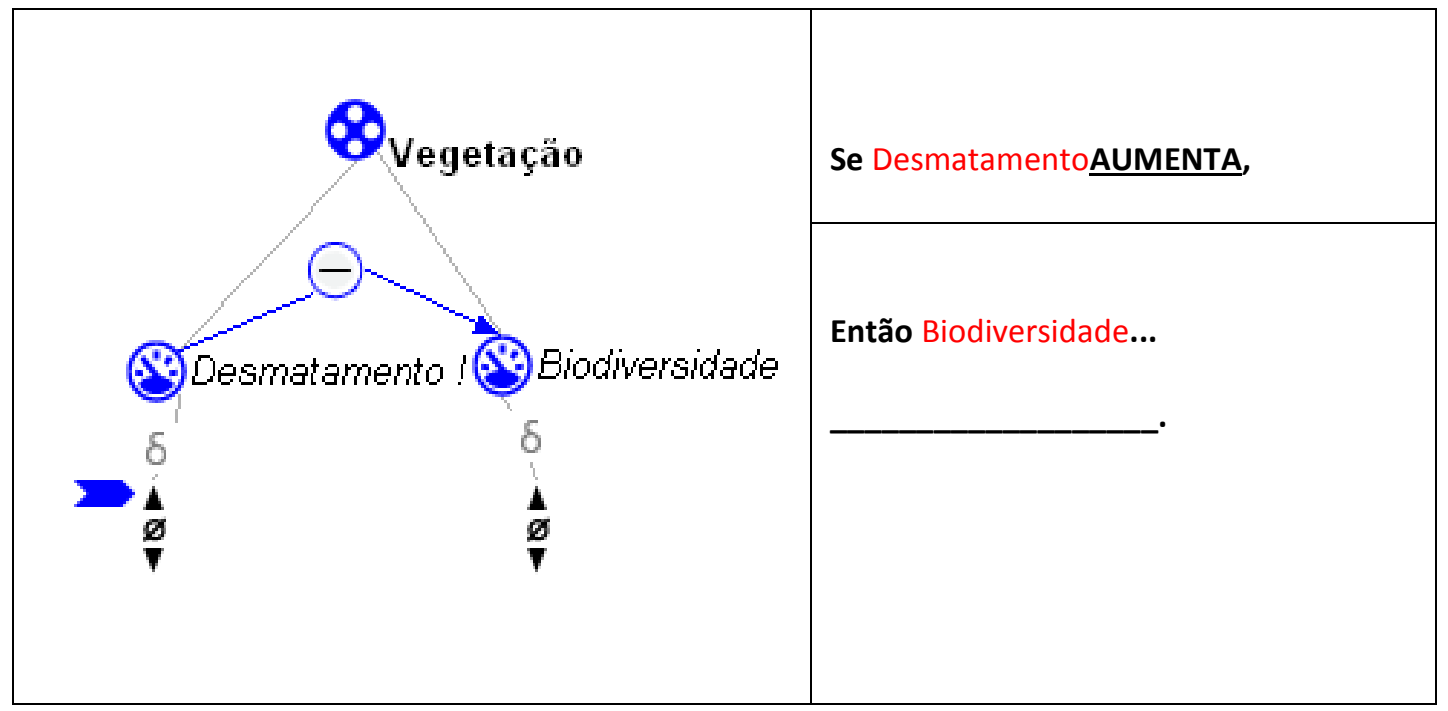

Essa questão permitiu verificara capacidade de os alunos conseguirem prever o que aconteceria com a 'Biodiversidade' quando o 'Desmatamento' apresentava uma derivada 'aumentando'. O resultado deve-se também à compreensão da relação de influência inversa representada pelo sinal (-). O mesmo foi verificado no modelo 2 , por ser semelhante a estrutura, porém, fazendo-se presente agora uma proporcionalidade positiva.

Modelo 2

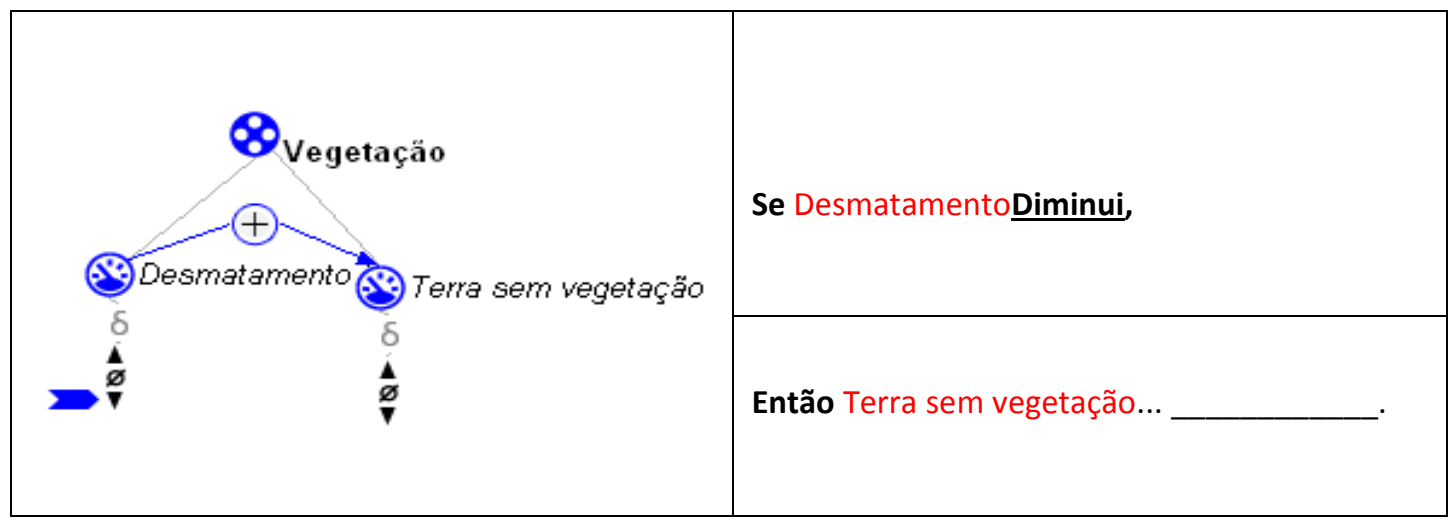

Esse modelo apresentou $100 \%$ de acertos. 
Modelo 3

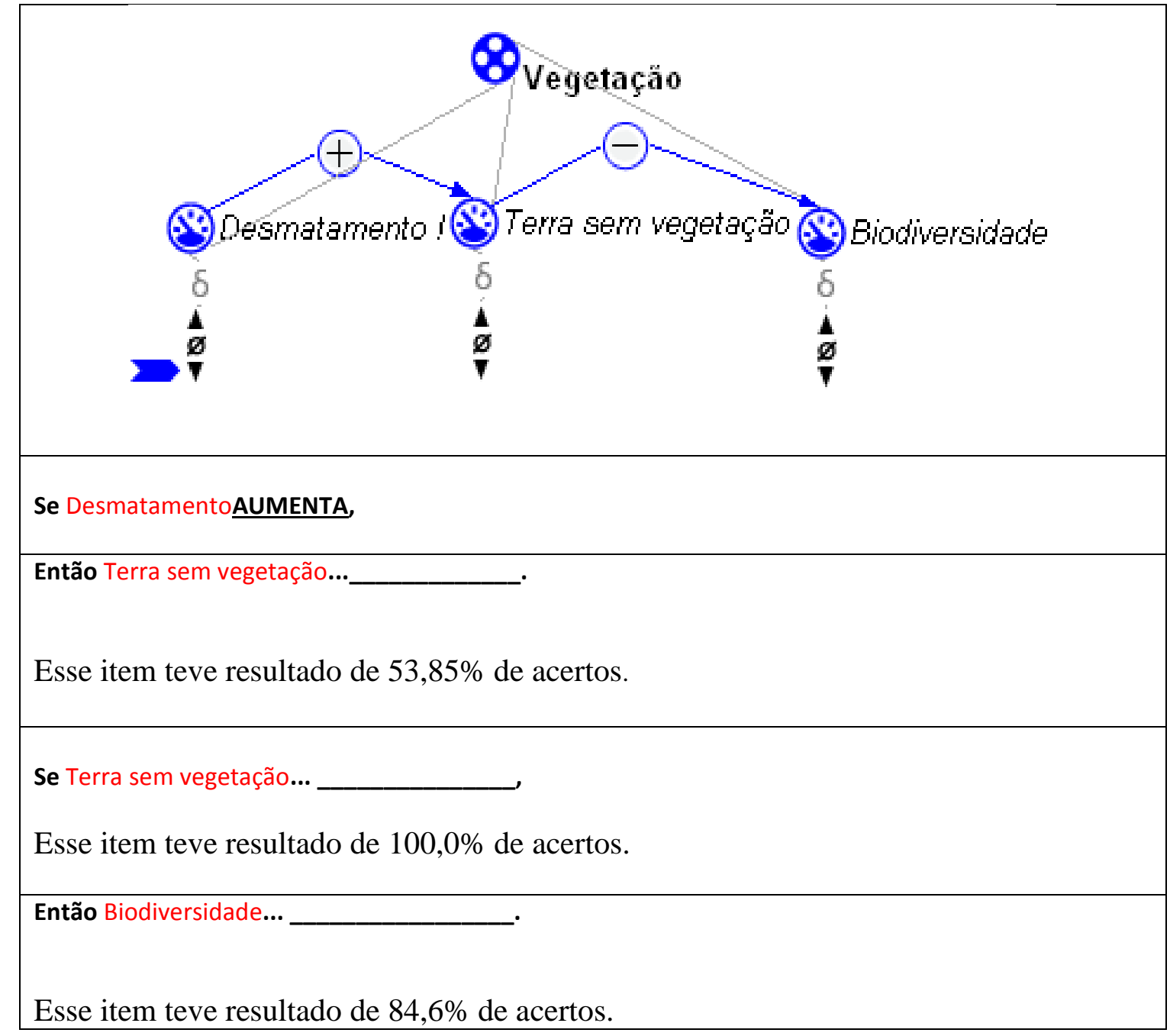

O modelo 3 apresentou resultado positivo, apesar de alguns alunos terem apresentado dificuldades na compreensão da dinâmica do sistema como um todo. Mesmo com essas dificuldades os alunos foram capazes de resolver mais de uma variação nas derivadas das quantidades presentes no modelo causal e com isso tornando possível a previsão do que ocorreria na sequência do 'Desmatamento' 'aumentando'. 
Modelo 4

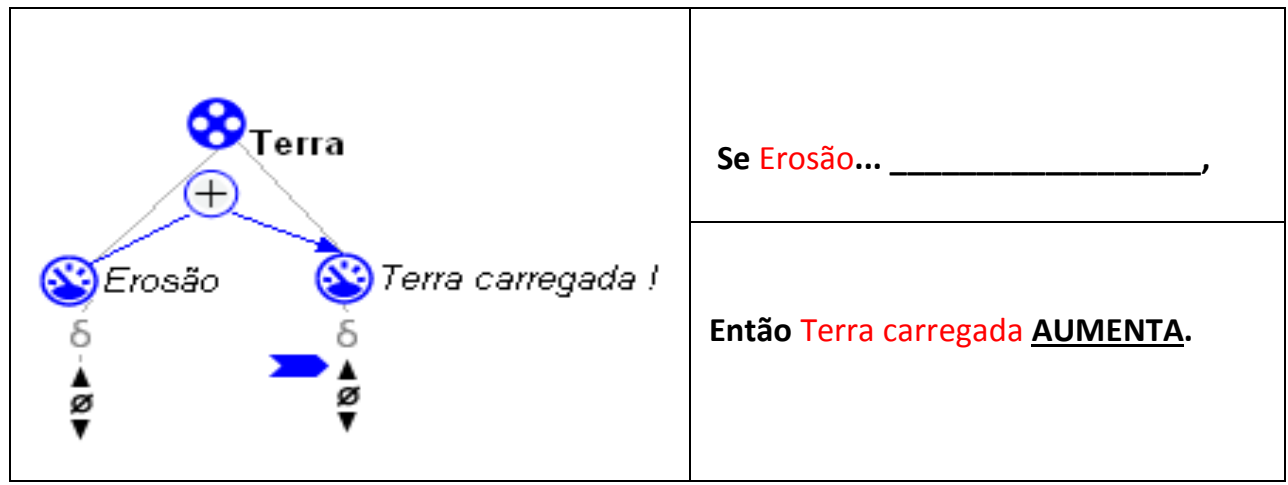

Esse modelo apresentou 76,9\% de acertos.

O resultado obtido com a resolução do proposto pelo modelo 4 foi de fundamental importância para a verificação da capacidade dos alunos levantarem hipóteses e fazerem deduções, uma vez que aproximadamente $77 \%$ dos alunos foram capazes de observar que para a 'Terra carregada' aumentar seria necessário que a 'Erosão' também estivesse aumentando.

No modelo 5 o raciocínio era igual ao apresentado para resolver o modelo 4, porém, por estar presente uma proporcionalidade negativa (-), os alunos apresentaram dificuldades em compreender essa relação inversa e com isso essa questão apresentou um resultado negativo, pois apenas $38 \%$ dos alunos conseguiram resolver essa questão de forma correta. Como apresentado a seguir:

Modelo 5

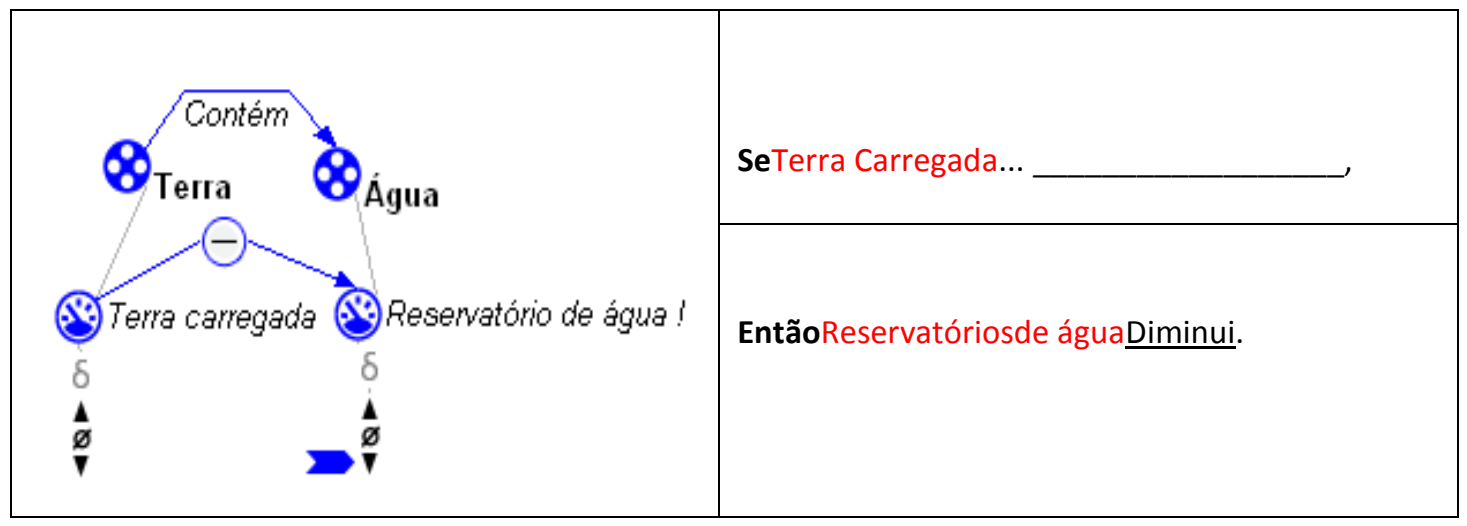

Esse modelo apresentou 76,9\% de acertos. 
Mas ao verificarmos uma combinação das relações de causalidade presentes no modelo 6 , em que estavam presentes as influências positivas e negativas, representando a sequência de eventos dentro do modelo causal, os resultados foram bastante positivos e apenas um aluno errou um dos itens desse modelo. Seguem os resultados apresentados na página seguinte:

Modelo 6

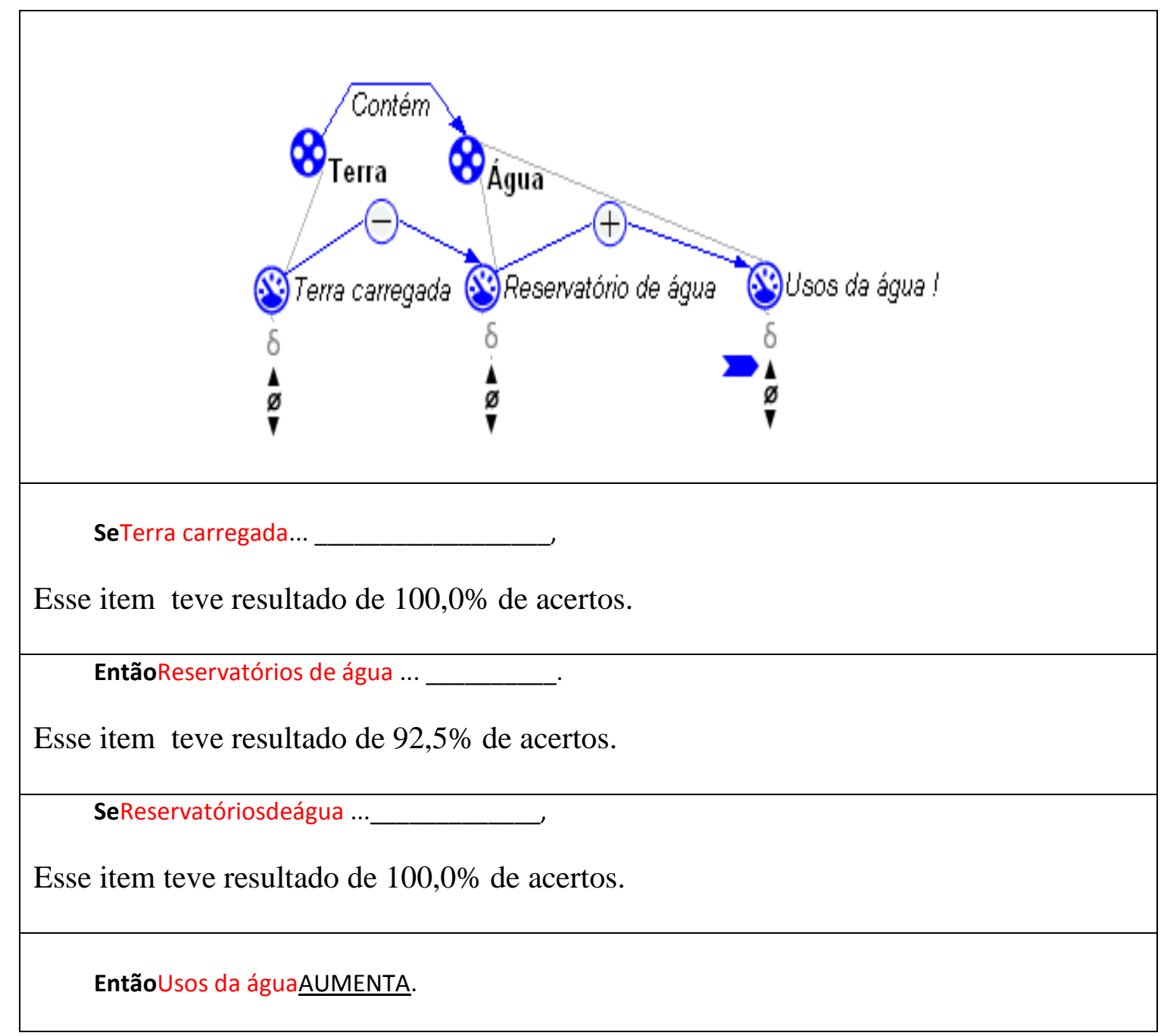

Do modelo 7 ao modelo 10 os resultados não foram bons, provavelmente, pelo fato de termos colocado um comando diferente do habitual e pedido para os alunos completarem os modelos com sinais de $(+)$ e de $(-)$, para depois responderem as assertivas com a respectiva relação de causalidade 'Positiva' ou 'Negativa'. Para trabalharmos com alunos surdos não devemos colocar muitas informações juntas em um mesmo comando de uma questão, e isso refletiu nos resultados negativos apresentados abaixo: 
Modelo 7

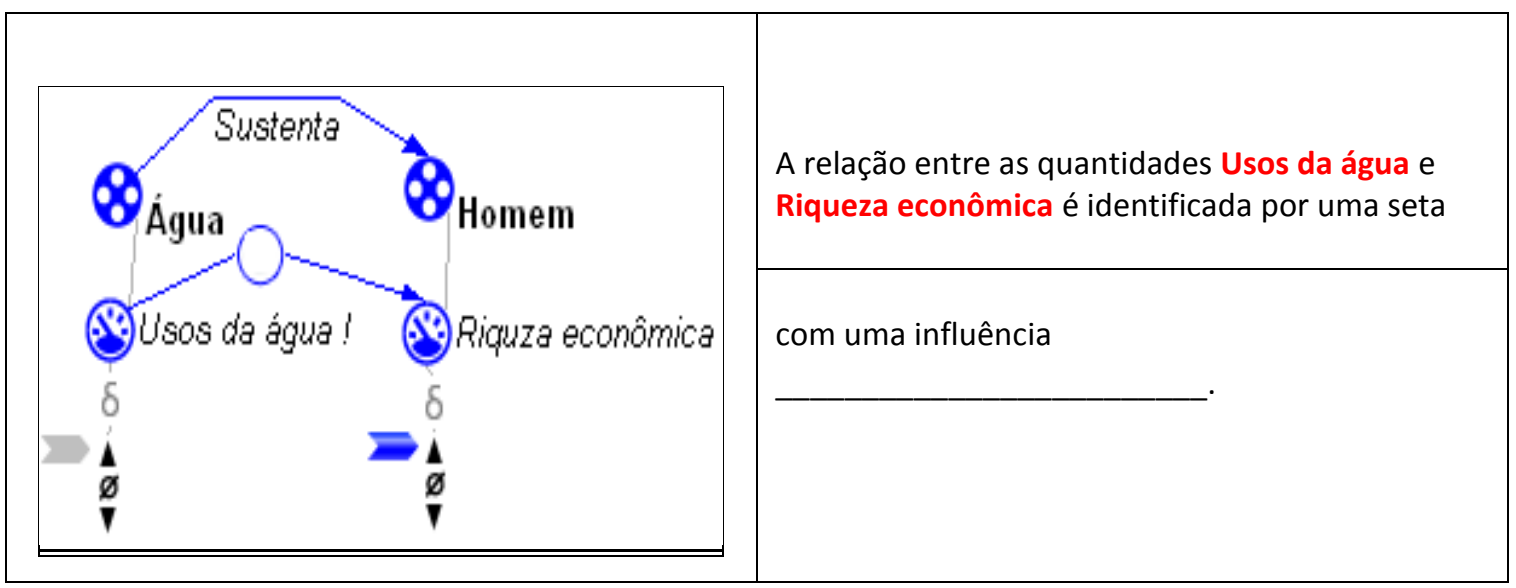

Esse modelo teve resultado de 53,85\% de acertos.

Modelo 8

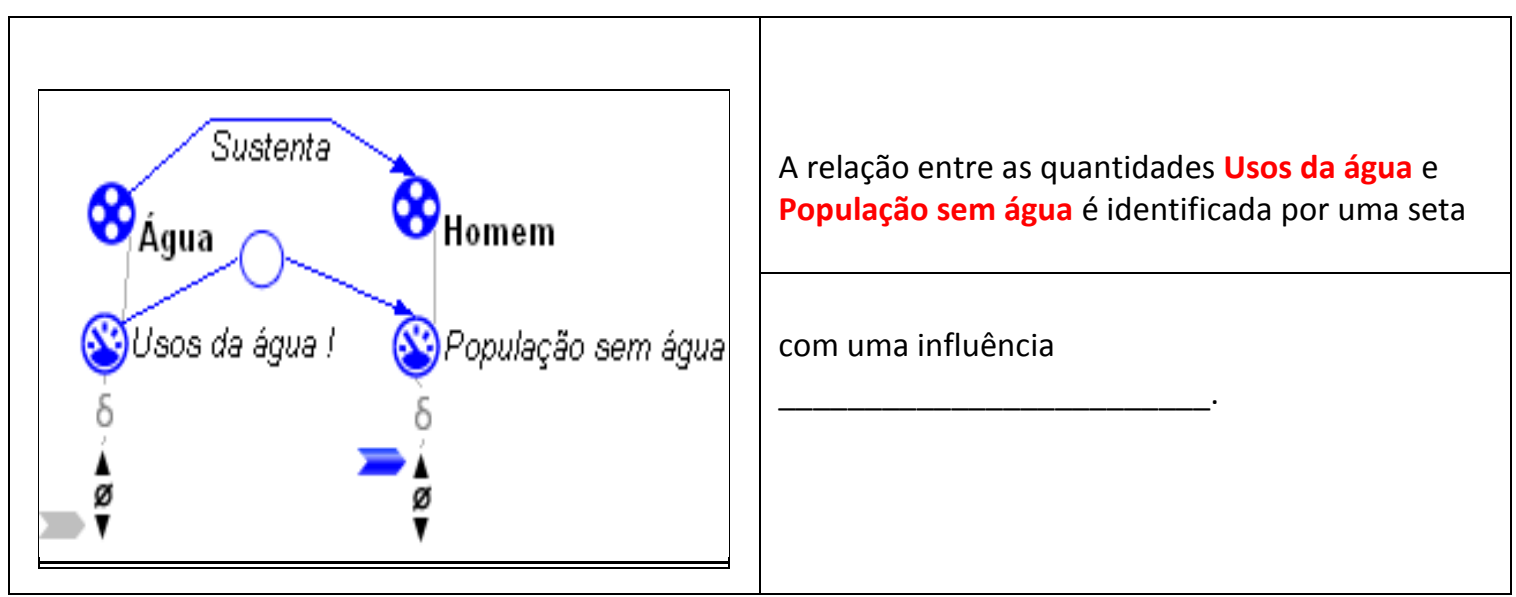

Esse item teve resultado de $53,85 \%$ de acertos. 
Modelo 9

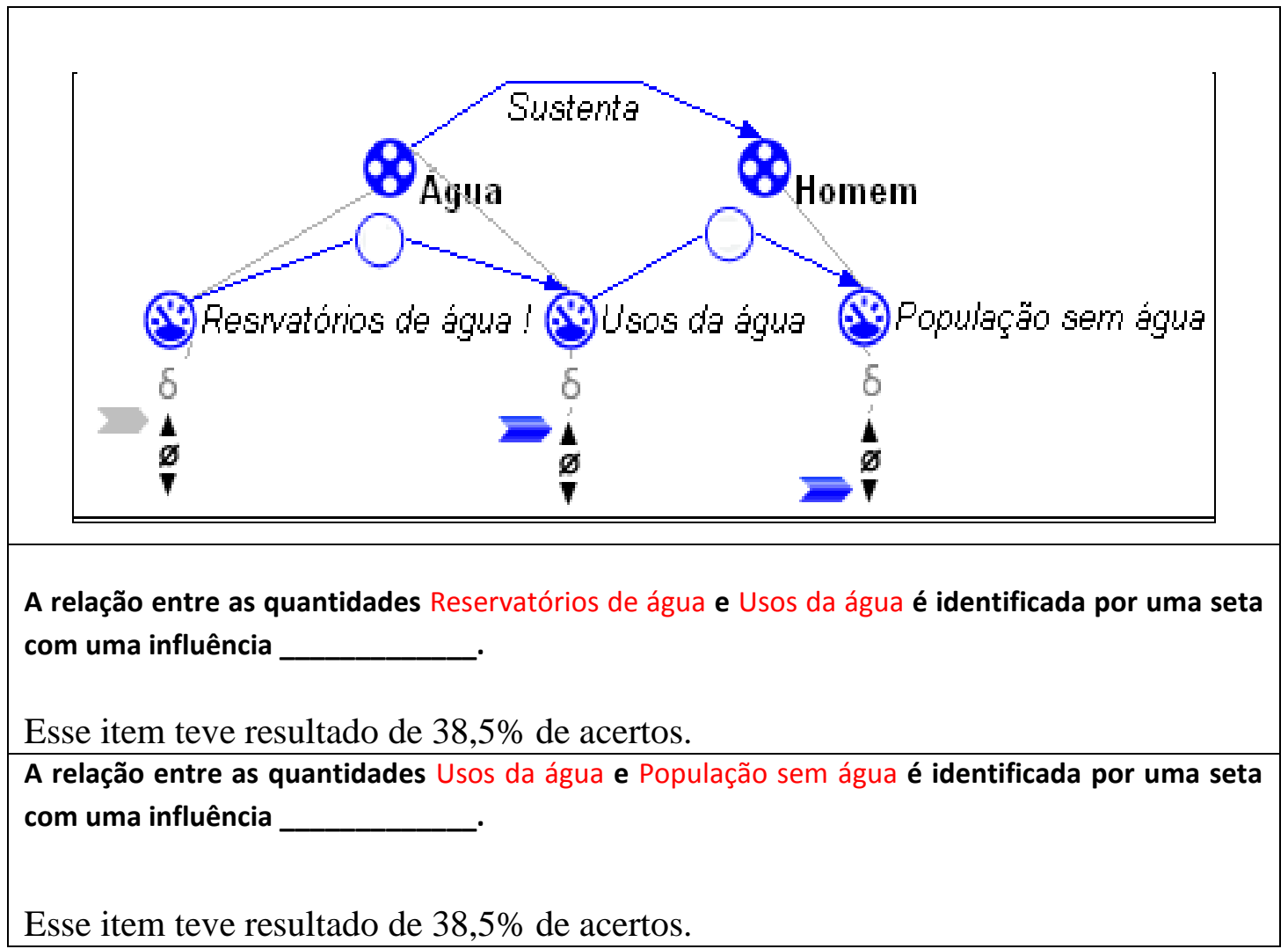

Modelo 10

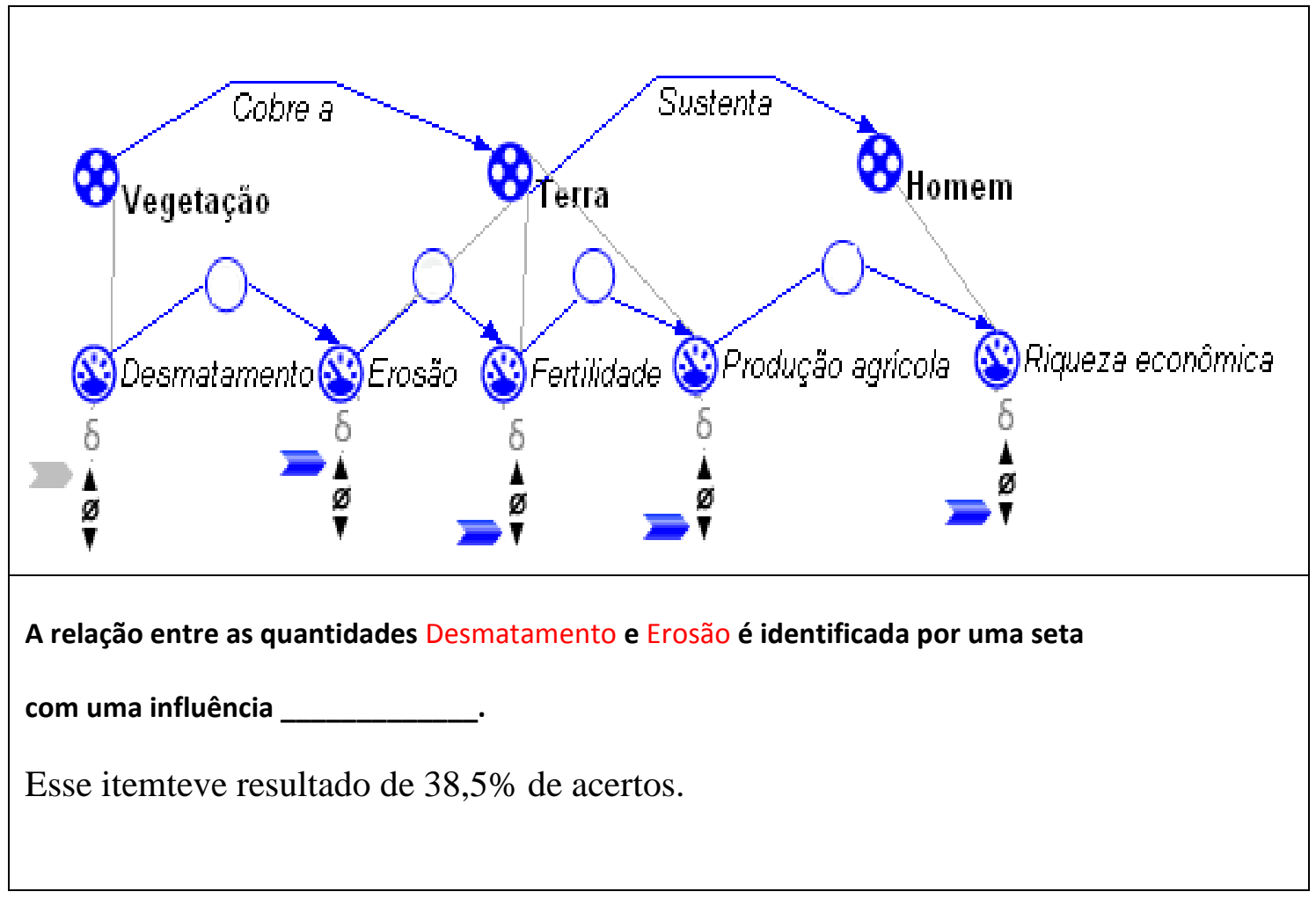


A relação entre as quantidades Erosão e Fertilidade é identificada por uma seta

com uma influência

Esse itemteve resultado de $38,5 \%$ de acertos.

A relação entre as quantidades Fertilidade e Produção agrícola é identificada por uma seta com uma influência

Esse itemteve resultado de $38,5 \%$ de acertos.

A relação entre as quantidades Produção agrícola e Riqueza econômica é identificada por uma seta com uma influência

Esse itemteve resultado de $38,5 \%$ de acertos.

Os resultados da Atividade 2 confirmam a necessidade de se investir mais na natureza da relação entre as variáveis, para que se possa identificar o tipo de influência (+ ou -) entre as quantidades influenciadora e influenciada.

\subsection{3 $\underline{\text { Resultados da Atividade } 3}$}

A Atividade 3 tinha por objetivo iniciar a exploração do modelo "Desmatamento". Os resultados obtidos com essa atividade demonstraram a capacidade dos alunos deduzirem os efeitos gerados pela variação da uma derivada de quantidade inicial presentes em dois modelos sobre desmatamento e dois modelos sobre regeneração.

A média de respostas certas foi igual a $72,5 \%$, sendo os resultados obtidos foram bastante positivos, uma vez que $83,4 \%$ dos alunos obtiveram médias superiores a $60 \%$ e apenas $16,6 \%$ dos alunos tiveram médias inferiores a 50\%, conforme mostra a Tabela 3 a seguir: 
Tabela3: Frequências das notas dos alunos na Atividade3 $(n=12)$

\begin{tabular}{c|c}
\hline Quantidade de alunos & Faixa de notas \\
\hline 3 & Igual a100\% \\
\hline 1 & Igual a 95\% \\
\hline 2 & Igual a $85 \%$ \\
\hline 1 & Igual a $80 \%$ \\
\hline 1 & Igual a 75\% \\
\hline 1 & Igual a 65\% \\
\hline 1 & Igual a $60 \%$ \\
\hline 1 & Igual a $10 \%$ \\
\hline 1 & Igual a 5\% \\
\hline
\end{tabular}

Osexercícios realizados com os cinco itens do modelo 1 da atividade 3, 'Desmatamento e Biodiversidade', nos quais deveriam se relacionar as derivadas das quantidades 'Terra sem vegetação', 'Terra com vegetação', 'Biodiversidade', 'Alimentos e remédios' e 'Riqueza econômica', partindo-se do crescimento da derivada da quantidade 'Desmatamento' (fígura 2), apresentaram os resultados contidos na tabela 4 a seguir:

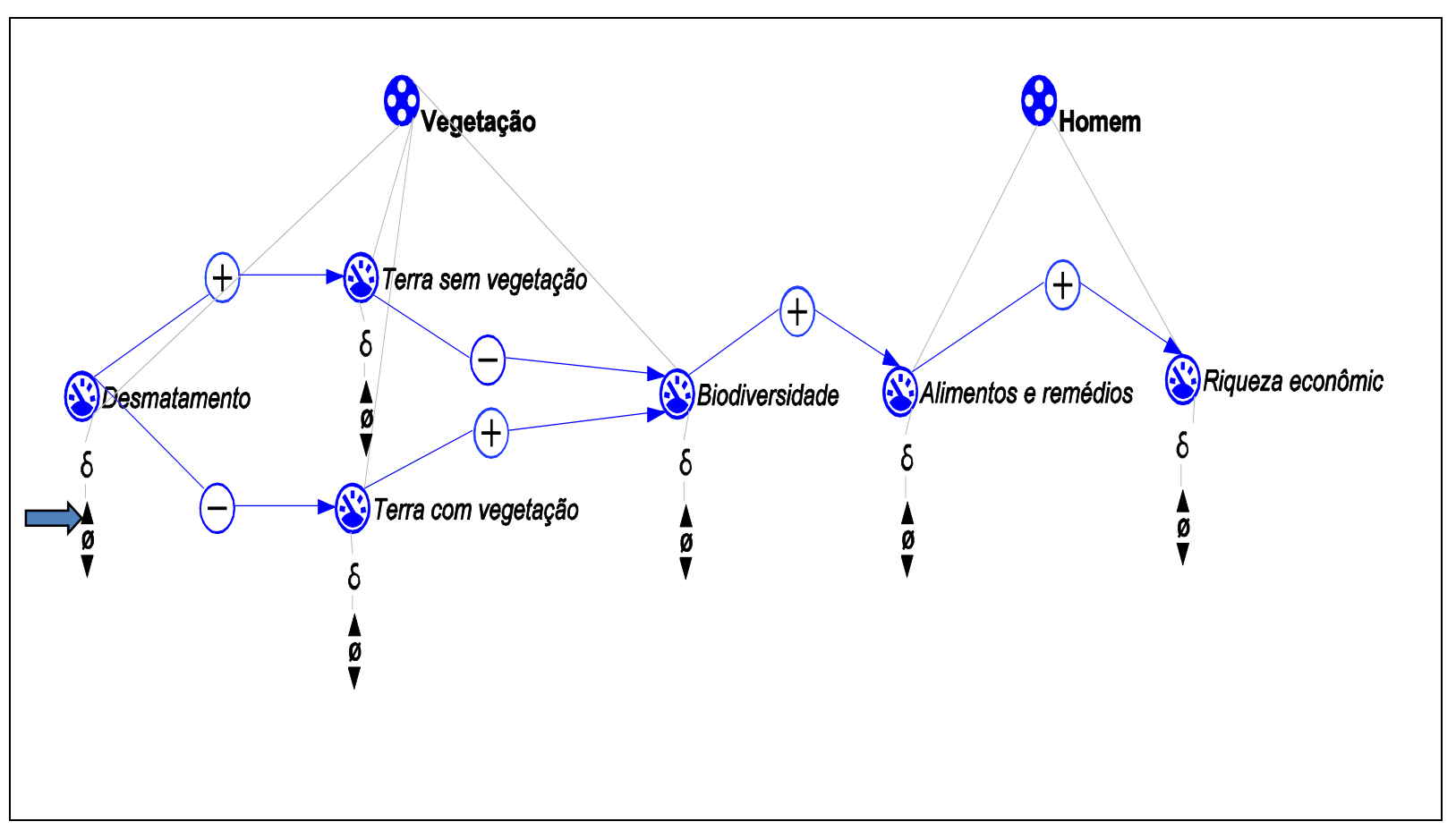

Figura 2- Desmatamento e Biodiversidade

Fonte: imagem gerada no software

Tabela4: Frequências de acertos e erros em cada item do modelo 'Desmatamento e Biodiversidade' ( $n=12)$.

\begin{tabular}{c|c|c}
\hline Derivada & Acertos & Erros \\
\hline Terra sem vegetação & $100 \%$ & $0 \%$ \\
\hline Terra com vegetação & $91,5 \%$ & $8,5 \%$ \\
\hline Biodiversidade & $83,4 \%$ & $16,6 \%$ \\
\hline Alimentos e remédios & $83,4 \%$ & $16,6 \%$ \\
\hline Riqueza econômica & $83,4 \%$ & $16,6 \%$ \\
\hline
\end{tabular}


Os resultados obtidos com os cinco itens do modelo 2 da atividade 3, 'Regeneração e Biodiversidade', em que deveriam se relacionar as derivadas das quantidades da mesma forma como feito no modelo anterior, mas, agora, partindo-se do crescimento da derivada da quantidade 'Regeneração', apresentou resultados inferiores aos anteriormente obtidos. Esses resultados podem indicar que os alunos compreenderam melhor os efeitos do 'Desmatamento' e assim deduziram os efeitos inversos gerados pelo crescimento da 'Regeneração'. Porém, a média de acertos, manteve-se acima de 50\%, como mostra aTabela 5:

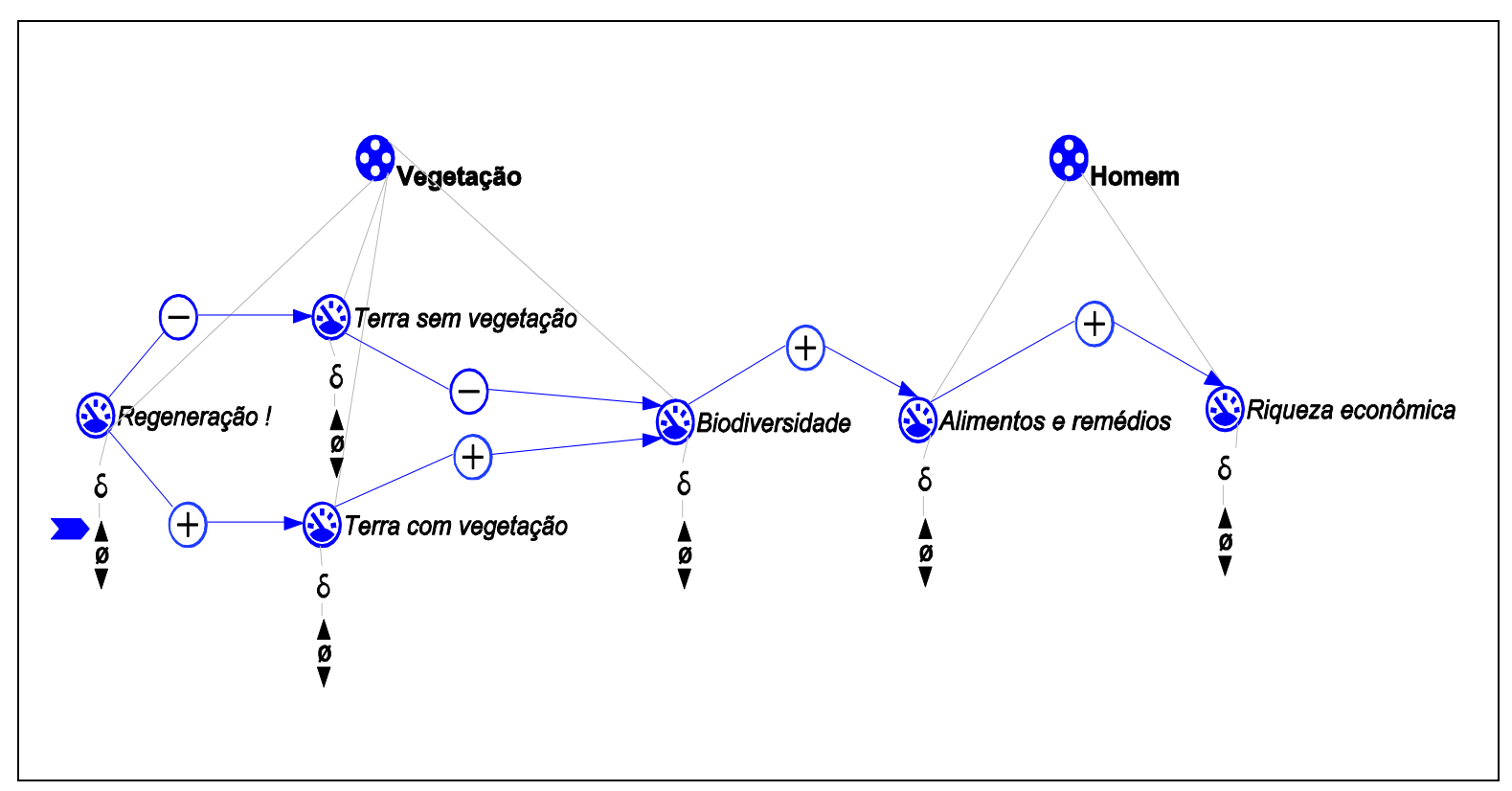

Figura 3-Regeneração e Biodiversidade Fonte: imagem gerada no software

Tabela5:Frequências de acertos e erros em cada item do modelo 'Regeneração e Biodiversidade' $(n=12)$

\begin{tabular}{c|c|c}
\hline Derivada & Acertos & Erros \\
\hline Terra sem vegetação & $66,7 \%$ & $33,3 \%$ \\
\hline Terra com vegetação & $75 \%$ & $25 \%$ \\
\hline Biodiversidade & $66,7 \%$ & $33,3 \%$ \\
\hline Alimentos e remédios & $66,7 \%$ & $33,3 \%$ \\
\hline Riqueza econômica & $58,5 \%$ & $41,5 \%$ \\
\hline
\end{tabular}

Da mesma forma, os resultados obtidos com a resolução do modelo abaixo mostraram que os alunos, em sua maioria, eram capazes de compreendere determinarem a variação das derivadas de quantidades presentes nos modelos, demonstrando uma clara compreensão da relação de causalidade envolvida no sistema. 


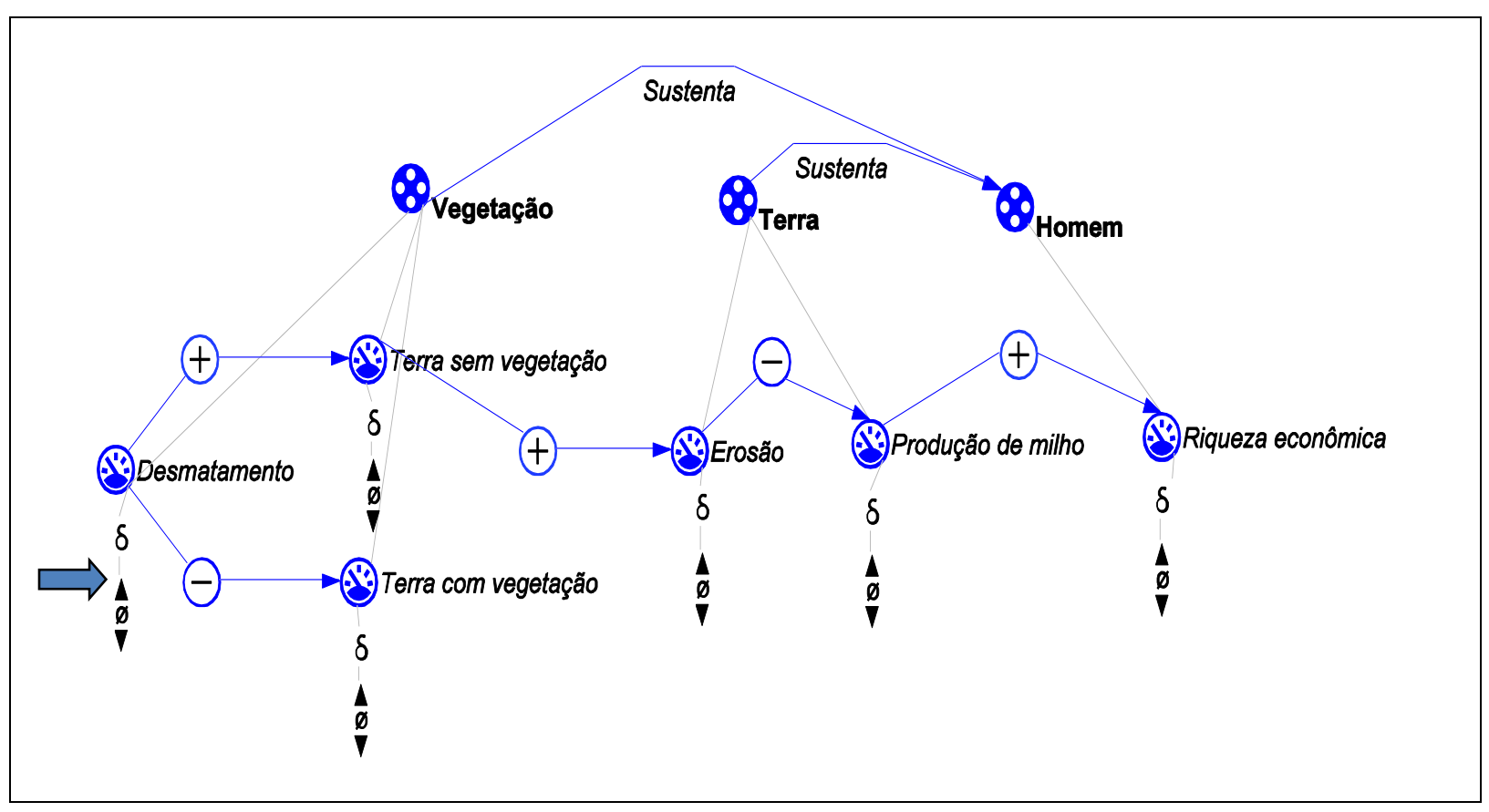

Figura 4- Desmatamento, Erosão, Produção agrícola e Riqueza econômica

Fonte: imagem gerada no software DynaLearn

Tabela6: Frequências de acertos e erros em cada item do modelo 'Desmatamento, Erosão, Produção agrícola e Riqueza econômica’ ( $\mathrm{n}=12)$.

\begin{tabular}{c|c|c}
\hline Derivada & Acertos & Erros \\
\hline Terra sem vegetação & $75 \%$ & $25 \%$ \\
\hline Terra com vegetação & $83,4 \%$ & $16,6 \%$ \\
\hline Erosão & $75 \%$ & $25 \%$ \\
\hline Produção de milho & $83,4 \%$ & $16,6 \%$ \\
\hline Riqueza econômica & $50 \%$ & $50 \%$ \\
\hline
\end{tabular}

Fato curioso pode ser verificado na resolução da ultima derivada. Ocorre que quando uma quantidade A se relaciona com uma quantidade B por meio de uma influência positiva e se a derivada da primeira estiver 'diminuindo', a segunda derivada deverá 'diminuir' também. Porém, pelo fato de a relação se dar por uma influência positiva, muitos alunos entendem que a segunda derivada deverá crescer, pelo fato de o sinal ser positivo. Por isso, trata-se de um tipo de relação de causalidade, em que os alunos fazem uma inferência errada a partir de uma situação já verificada em outros modelos e exemplificada a seguir: 


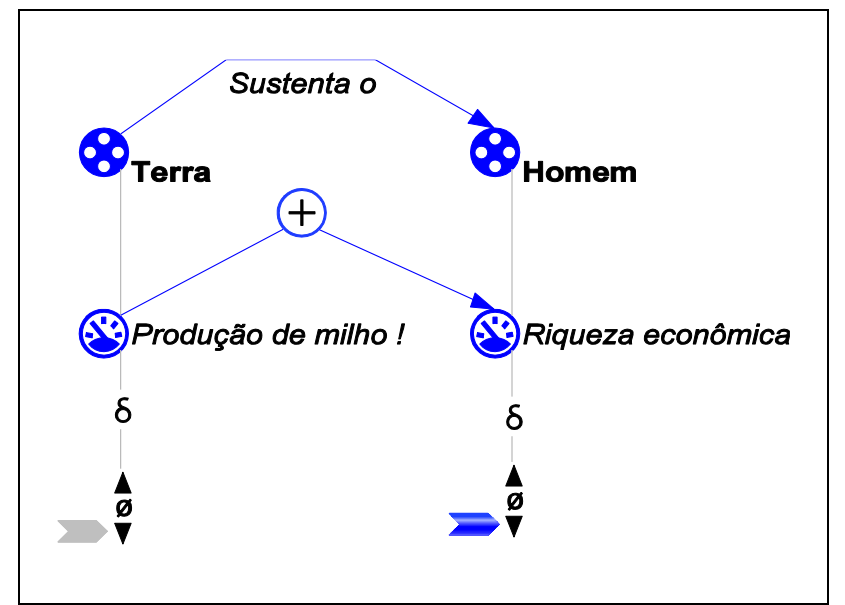

Figura 5- Produção de milho e Riqueza econômica -LS2 Fonte: imagem gerada no software

Foi possível verificar a ocorrência de respostas em desacordo, quando fato semelhante ocorre nos modelos. Isso pode se dever principalmente ao aluno relacionar o sinal de positivo com algo que está aumentando, porém sem levar em consideração o sentido e a direção, o que faz o aluno a mudar o sentido para indicar o crescimento da derivada.

Resultados semelhantes também foram obtidos com o modelo da 'Regeneração' em uma relação causal igual à trabalhada no modelo anterior e presente na relação causal entre a ‘Terra sem vegetação’ e ‘Erosão', e na relação causal seguinte, entre a ‘Erosão’ e a 'Produção de milho', como apresentado abaixo:

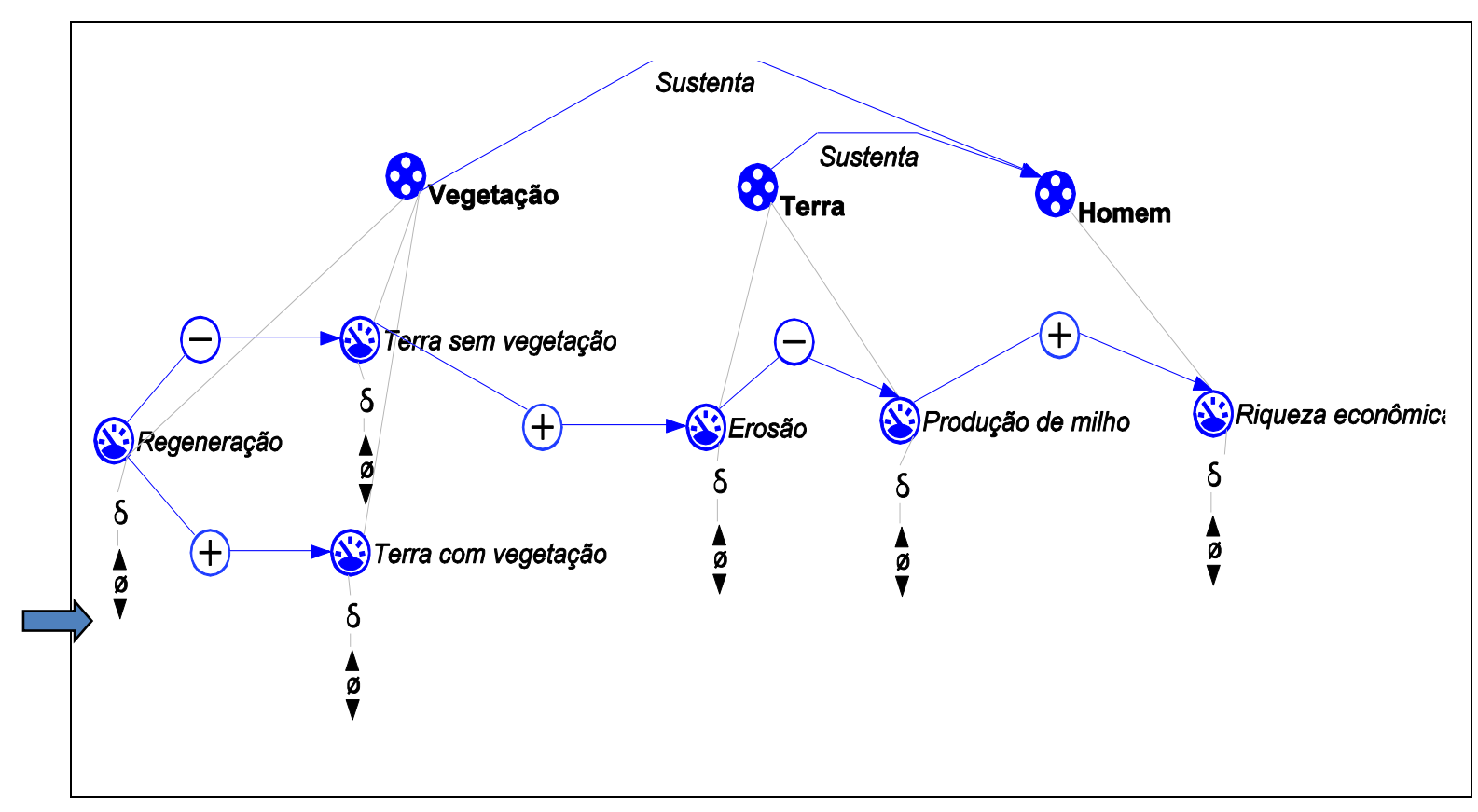

Figura 6-Regeneração, Erosão, Produção agrícola e Riqueza econômica Fonte: imagem gerada no software 
Tabela7: Frequências de acertos e erros em cada item do modelo 'Regeneração, Erosão, Produção agrícola e Riqueza econômica'(n=12)

\begin{tabular}{c|c|c}
\hline Derivada & Acertos & Erros \\
\hline Terra sem vegetação & $75 \%$ & $25 \%$ \\
\hline Terra com vegetação & $66,7 \%$ & $33,3 \%$ \\
\hline Erosão & $41,7 \%$ & $58,3 \%$ \\
\hline Produção de milho & $41,7 \%$ & $58,3 \%$ \\
\hline Riqueza econômica & $66,7 \%$ & $33,3 \%$ \\
\hline
\end{tabular}

O resultado obtido com este modelo pode confirmar o fato relatado anteriormente, em que quando uma derivada está 'diminuindo' e a relação causal entre a quantidade seguinte é positiva, há uma interpretação errônea da relação de causalidade, que leva os alunos a responderem que a derivada da segunda quantidade ira crescer ao invés de diminuir. Este tipo de resposta ocorreu em pouco mais de $58 \%$ dos casos analisados.

\subsubsection{Resultados da Atividade 4}

Os resultados obtidos com a 'Atividade4', mostraram uma evolução dos alunos em relação à ',Atividade3', principalmente no desempenho de dois alunos que obtiveram notas de $5 \%$ e de $10 \%$ na atividade anterior. A melhora desses alunos foi significativa, pois na 'Atividade 4', semelhante à de número 3, os alunos passaram de uma notas de 5\% para 55\%, enquanto o outro aluno, passou de $10 \%$ para $50 \%$.

Também foi registrado $100 \%$ de aproveitamento para três alunos que fizeram essa atividade. Três alunos reduziram suas notas em pouco mais de 10 pontos percentuais.

A 'Atividade 4' era composta por três modelos, sendo que dois deles contemplavam todas as relações causais trabalhadas com os alunos, na representação do desmatamento, no modelo 1, e da regeneração, no modelo 2. Como resultado do trabalho com esses dois modelos, os alunos compreenderam claramente as relações de causalidade presentes nos mesmos, sendo que apenas um aluno obteve média inferior a $50 \%$.

O resultado do último modelo buscou confirmar o fenômeno registrado anteriormente, em que os alunos interpretavam o sinal de proporcionalidade positiva como uma sequência de crescimento para a derivada da quantidade seguinte. Os resultados obtidos com esse item após uma nova intervenção foi que apenas dois alunos responderam em desacordo com o que se esperava como resposta, o que corresponde a $18,2 \%$, enquanto que os outros $81,8 \%$ compreenderam esse tipo de relação causal, não apresentando maiores dificuldades em 
estabelecer o mesmo tipo de relação em modelos com características semelhantes à relatada aqui.

De modo geral, tanto a 'Atividade 4' quanto a 'Atividade 3', apresentaram resultados bastante expressivos. Deve-se levar em conta que, por se tratar de modelos que estabelecem uma relação causal em sequência dentro do modelo, quando o aluno erra uma derivada, esse erro pode se propagar para a interpretação da relação causal de todo o modelo e levar o aluno a ter um desempenho bem inferior ao que seria da resolução de um item isolado.

Portanto, mesmo com a complexidade apresentada na relação de causalidade de modelos completos, observou-se que os alunos foram capazes de desenvolver toda a estrutura de relação de causalidade entre as quantidades, confirmandoo potencial dessas ferramentas para o desenvolvimento do raciocínio hipotético dedutivo em alunos surdos, como já demonstrado em trabalhos anteriores (SALLES et al., 2004 e 2005; FELTRINI, 2009; RESENDE, 2010). Confirma-se também o potencial do RQ, e dos modelos qualitativos,para a aquisição de conceitos e, em última análise, para a educação científica de alunos surdos.

O desempenho dos alunos está relatado na tabela abaixo:

Tabela8: Frequências das notas dos alunos na Atividade4 $(\mathrm{n}=11)$

\begin{tabular}{c|c}
\hline Quantidade de alunos & Faixa de notas \\
\hline 3 & Igual a100\% \\
\hline 1 & Igual a 95\% \\
\hline 1 & Igual a $90 \%$ \\
\hline 1 & Igual a $65 \%$ \\
\hline 3 & Igual a $55 \%$ \\
\hline 1 & Igual a $50 \%$ \\
\hline 1 & Igual a $40 \%$ \\
\hline
\end{tabular}

\subsubsection{Resultados dos testes aplicados aos alunos surdos}

Os principais resultados para se comprovar a hipótese do presente trabalho de pesquisa foram o pré e o pósteste sobre temas de desmatamento. Estes resultados estão expostos nas duas seções a seguir.

\subsubsection{Resultados do Préteste}

O préteste foi realizado com 18 alunos, logo após a realização da Atividade 1. Os resultados obtidos com o teste em questão forambemvariados, porém a maioria das notas 
ficou entre $50 \%$ e $70 \%$ de acertos, sendo que a maédia dos 18 alunos foi de 53,9\%, distribuídas como apresentado na tabela abaixo:

Tabela9: Frequência de notas de todos os alunos que fizeram o préteste $(n=18)$.

\begin{tabular}{c|c}
\hline Quantidade de alunos & Faixa de notas \\
\hline 2 & Superior a $70 \%$ \\
\hline 10 & Superior a 50\% e inferior a $70 \%$ \\
\hline 6 & Inferior a $50 \%$ \\
\hline
\end{tabular}

Porém, ao longo do tempo muitos alunos foram desistindo ou deixando de fazer as atividades programadas para ao curso. Por esse motivo, foram consideradas, na comparação entre pré e pós testes, apenas as notas dos 12 alunos que participaram de praticamente todas as atividades e fizeram ambos os testes. Essa medida era essencial para poder aplicar os testes estatísticos paramétrico e não paramétrico escolhidos, pois ambos eram 'pareados', isto é, requeriam pares de notas associados a cada aluno considerado na amostra. Entre estes, a nota média foi de $51,6 \%$ e as frequências dos resultados das notas estão apresentadas na tabela abaixo:

Tabela10: Frequência de notas dos alunos no préteste que participaram de todas as atividades do curso $(n=12)$.

\begin{tabular}{c|c}
\hline Quantidade de alunos & Faixa de notas \\
\hline 1 & Superior a 70\% \\
\hline 7 & Superior a 50\% e inferior a 70\% \\
\hline 1 & Inferior a 50\% e superior a 44\% \\
\hline 3 & Inferior a 44\% \\
\hline
\end{tabular}

\subsubsection{Resultados do pósteste}

Os resultados obtidos com o pósteste foram melhores que os resultados obtidos com o préteste, sendo que a média das notas dos alunos subiu para 59,9\%, indicando uma melhora em relação ao préteste de 8,3 pontos percentuais.

Tabela11: Frequência de notas dos alunos no pósteste que participaram de todas as atividades do curso $(\mathrm{n}=12)$.

\begin{tabular}{c|c}
\hline Quantidade de alunos & Faixa de notas \\
\hline 4 & Superior a $70 \%$ \\
\hline 3 & Superior a 50\% e inferior a $62 \%$ \\
\hline 4 & Inferior a 50\% e superior a $44 \%$ \\
\hline 1 & Inferior a $44 \%$ \\
\hline
\end{tabular}


As questões de 1 a 14, para julgar enunciados e assinalar (C) para 'Certo' e (E) para 'Errado', foram as que apresentaram um maior número de respostas corretas. Nas questões que deveriam ser respondidasescrevendo-se a resposta 'Aumenta' ou 'Diminui', os alunos apresentaram um maior grau de dificuldade para ler e interpretar a relação de causalidade apresentada na forma de texto. Porém, apesar disso, a maioria conseguiu responder com êxito a esse tipo de questão.

Entretanto, apesar da melhora das notas observada na maioria dos alunos, três alunos tiveram uma redução de aproximadamente 10 pontos percentuaisna nota do pós teste, comparada com sua primeira nota.

\subsubsection{Resultados das análises estatísticas obtidas da comparação entre o pré e pós-teste aplicados aos alunos surdos}

Com os dados obtidos no pré e pós testes, foram feitas análises estatísticas por meio de duas abordagens, paramétrica e não paramétrica. A aplicação do teste paramétrico $t$ de Student, para o nível de significância de $5 \%$, foi resultou em $\mathrm{t}=2,050549$, associado a uma probabilidade $\mathrm{p}=0,032457$. Esse resultado permite descartar a hipótese de nulidade $\left(\mathrm{H}_{0}\right)$ e aceitar a hipótese alternativa de que o uso de modelos teve impacto positivo no desenvolvimento do raciocínio hipotético-dedutivo dos alunos surdos.

Da mesma forma, a aplicação do teste não paramétrico de Wilcoxon, para umnível de significância de 5\%, resultou em um valor $\mathrm{V}=16,0$, associado à probabilidade $\mathrm{p}=$ 0,038721043. Portanto, o resultado também permite afastar a hipótese nula em favor da hipótese de que o uso de modelos contribuiu para o desenvolvimento do raciocínio hipotéticodedutivo dos alunos que participaram das atividades realizadas.

Com esses resultados, reafirma-se a potencialidade do uso de modelos qualitativos criados em LS2 na educação científica de alunos surdos e no desenvolvimento da capacidade dos alunos fazerem inferências por meio do uso de raciocínio hipotético-dedutivo.

\subsubsection{Resultados dos questionários de avaliação aplicados aos alunos surdos}

Doze alunos surdos puderam deixar suas impressões sobre o curso e a modelagem por meio de um questionário já aplicado anteriormente na pesquisa de Resende (2010). Por se tratar de um questionário adaptado visualmente a atender melhor os objetivos de se trabalhar 
com alunos surdos, os alunos deveriam responder as questões de acordo com a legenda contida abaixo:

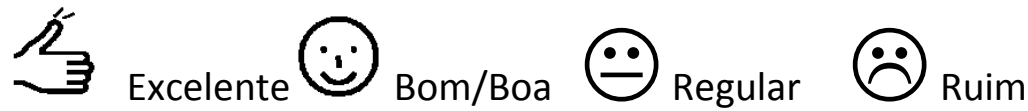

Como resultado, os alunos, em sua maioria, deram mais respostas do tipo: Excelente e Bom/Boa, como apresentado no quadro e discutido em seguida:

Quadro 2- Resultados da avaliação feita pelos alunos surdos sobre as atividades realizadas(n=12)

\begin{tabular}{|c|c|c|c|c|}
\hline $\begin{array}{l}\text { Avalie os itens a seguir marcando a resposta com um X no } \\
\text { quadro apropriado. }\end{array}$ & $2_{3}^{3}$ & & 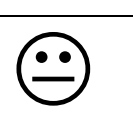 & \\
\hline 1. Qual a sua opinião sobre a apresentação geral do curso? & $66,6 \%$ & $25 \%$ & $3,4 \%$ & $0 \%$ \\
\hline $\begin{array}{l}\text { 2. O que você achou do conteúdo das atividades propostas } \\
\text { no curso? }\end{array}$ & $50 \%$ & $50 \%$ & $0 \%$ & $0 \%$ \\
\hline $\begin{array}{l}\text { 3. Qual a sua opinião sobre o softwareDynaLearn, utilizado } \\
\text { para construir os modelos qualitativos? }\end{array}$ & $33,3 \%$ & $41,7 \%$ & $16,7 \%$ & $8,3 \%$ \\
\hline $\begin{array}{l}\text { 4. Qual a sua opinião sobre a linguagem (entidades, } \\
\text { influências, proporcionalidades) utilizada para construir os } \\
\text { modelos qualitativos? }\end{array}$ & $25 \%$ & $58,4 \%$ & $8,3 \%$ & $8,3 \%$ \\
\hline $\begin{array}{l}\text { 5. Qual a sua opinião sobre a clareza dos conceitos } \\
\text { expressos nos modelos qualitativos? }\end{array}$ & $41,7 \%$ & $41,7 \%$ & $16,6 \%$ & $0 \%$ \\
\hline $\begin{array}{l}\text { 6. O que você achou do vocabulário usado nos modelos } \\
\text { qualitativos para descrever os assuntos abordados? }\end{array}$ & $25 \%$ & $58,4 \%$ & $8,3 \%$ & $8,3 \%$ \\
\hline $\begin{array}{l}\text { 7. Qual a sua opinião sobre a clareza na apresentação das } \\
\text { relações de causa - efeito nos modelos qualitativos? }\end{array}$ & $58,4 \%$ & $33,3 \%$ & $8,3 \%$ & $0 \%$ \\
\hline $\begin{array}{l}\text { 8. Como você classifica o seu entendimento sobre os } \\
\text { problemas apresentados, depois de estudar os modelos } \\
\text { qualitativos? }\end{array}$ & $66,6 \%$ & $16,7 \%$ & $16,7 \%$ & $0 \%$ \\
\hline $\begin{array}{l}\text { 9. Como você avalia a contribuição dos modelos qualitativos } \\
\text { para a sua aprendizagem? }\end{array}$ & $41,7 \%$ & $50 \%$ & $8,3 \%$ & $0 \%$ \\
\hline $\begin{array}{l}\text { 10. O que você acha da ideia de usar modelos qualitativos } \\
\text { na sala de aula? }\end{array}$ & $33,4 \%$ & $50 \%$ & $8,3 \%$ & $8,3 \%$ \\
\hline
\end{tabular}

$\mathrm{Na}$ questão de número 1 , mais de $90 \%$ gostaram da apresentação do curso respondendo que o mesmo foi 'Excelente' (66\%) e 'Boa/Bom' (25\%) e apenas um aluno respondeu que foi 'Regular'. Este resultado demonstra que os alunos se interessaram pelo curso e gostaram do mesmo.

O mesmo foi verificado na questão de número 2, pois $50 \%$ dos alunos acharam o conteúdo do curso excelente e os outros $50 \%$ acharam bom. Não houve respostas de 'Regular', ou 'Ruim'. Portanto, o conteúdo abordado no curso, também despertou interesse 
dos alunos e os motivou a participar de forma ativa e entusiasmada, como verificado durante os encontros.

Quando indagados sobre o que acharam do software DynaLearn, apenas 1 pessoa, que corresponde a 8,33\%, achou 'Ruim', fato que pode ser compreendido, devido à complexidade do programa. Outros 16,66\% acharam o software 'Regular' e a maioria achou o software 'Excelente' $(33,3 \%)$ ou $(41,6 \%)$ 'Bom'. Esses resultados confirmam a aceitação do uso do software DynaLearn.

Resultados muito semelhantes foram obtidos nas questões seguintes, 4 e 5, mostrando que os alunos gostaram da linguagem utilizada para representar as entidades, as influências e as proporcionalidades presentes nos modelos (questão 4, com 83,4\% de "Excelente" e "Bom", assim como a clareza dos conceitos representados nos mesmos, com o auxilio de recursos visuais, afim de adequar o que estava sendo trabalhado a uma abordagem pedagógica visual, adequada ao trabalho com alunos surdos (também com 83,4\% de "Excelente" e "Bom", questão 5).

Da mesma forma nas questões 6 e 7, os alunos acharam em sua maioria que o vocabulário utilizado e a clareza na apresentação das relações de causa e efeito nos modelos foram 'Excelente', ou 'Bom', sendo que apenas 8,33\% acharam o vocabulário utilizado 'Ruim' e outros $8,33 \%$, acharam o vocabulário e a clareza na relação de causa e efeito, 'Regular'.

Esses resultadosdemonstram que os alunos conseguiram compreender os problemas representados nos modelos e por isso não houve nenhuma resposta desfavorável nas questões 8 e 9, sendo que na questão 8, teve muitos alunos (66,6\%), que responderam 'Excelente' e outros 91 \%, responderam 'Excelente'ou 'Bom', para a questão de número 9. Isso confirma a potencialidade dos modelos em contribuir para o aprendizado de alunos surdos.

O resultado da questão 10 demonstra a aceitação do uso de modelos pelos alunos surdos na realização de atividades desenvolvidas em sala. Além desses resultados positivos obtidos nos questionários, o fato aqui citado pode também ser observado nos encontros presenciais, em que houve um interesse e uma participação efetiva dos alunos.

\subsection{Resultados das análises das entrevistas aplicadas aos professores/intérpretes}

Nessa seção estão apresentados os resultados das análises de aproximadamente duas horas de gravações das entrevistas realizadas com os professores que auxiliaram nas 
atividades do curso e nas interpretações das aulas em LIBRAS. Para a coleta dos dados analisados, foi realizada uma entrevista semi-estruturada (FUJISAWA, 2000), que se baseou em um roteiro com 19 perguntas que se dividiam em categorias e que seus resultados serão aqui apresentados em sub-seções, sendo elas: 4.2.1 Experiência com modelagem, 4.2.2 Modelos e Simulações, 4.2.3 Usos na Educação, 4.2.4 Software e 4.2.5 Questões abertas.

\subsubsection{Experiências com modelagem}

Nesta parte, os professores deveriam responder as seguintes perguntas:

“(1) Você compreendeu claramente o objetivo das tarefas de modelagem?”

“(2) Na sua opinião, a modelagem foi uma tarefa motivadora para alunos surdos?”

"(3) O que você achou da modelagem conceitual? Modelos conceituais e simulações poderiam efetivamente ser ferramenta de apoio à aprendizagem de alunos surdos?"

Nos resultados obtidos com a primeira pergunta, os professores disseram ter compreendido os objetivos das tarefas de modelagem, gostaram muito da abordagem utilizada e viram na modelagem uma ferramenta de suporte ao ensino e de possível trabalho em conjunto com várias disciplinas, sendo sugerida a possível utilização de modelos em trabalhos interdisciplinares, pois viram nessa ferramenta um suporte para a realização de trabalhos que envolvessem mais de uma área do conhecimento, inclusive o Português na modalidade escrita.

\footnotetext{
"Ficou muito claro, inclusive o aspecto relacionado ao visual, mostrando o conceito junto com o visual."

"Sim, ficou claro que os objetivos eram aumentar a capacidade de raciocínio lógico, especialmente de alunos surdos e fazer com que eles se motivassem na escrita do Português."
}

$\mathrm{Na}$ segunda questão foi possível perceber as impressões positivas que o professores tiveram da participação dos alunos, pois em seus relatos fica evidente a empolgação que os alunos tiveram na realização das atividades de modelagem e na assiduidade dos que participaram ativamente deste processo. Estes resultados, assim como esperado, repetem os 
resultados apresentados em trabalhos anteriores de Salles, 2004 e 2005, assim como o de Feltrini, 2009 e de Rezende, 2010.

"A modelagem foi tarefa motivadora e percebi ao longo do curso a participação dos alunos e quando eles tinham alguma dúvida faziam perguntas e questionando sobre as situações-problema."

"Foi muito motivadora, os alunos gostaram muito e durante a semana ficavam ansiosos pelo próximo encontro."

"Sim, houve até uma disputa entre os alunos para ver quem concluía primeiro a atividade, gerando uma disputa saudável entre alguns dos alunos participantes."

A terceira pergunta, apesar de ter gerado poucas dúvidasnos entrevistados, levou-os a refletirem um pouco para que pudessem responder. Os resultados obtidos foram positivos em todos os depoimentos, sendo que as respostas convergiram para os aspectos benéficos do uso dessa abordagem e propunham que essa ferramenta fosse utilizada de maneira interdisciplinar.

"Sim, pois ajudam a trabalhar conceitos que levam à compreensão de problemas sociais, sendo isso de grande importância para os alunos surdos."

"Poderiam sim, principalmente pela questão visual e pela oportunidade de se trabalhar de forma interdisciplinar, explorando o Português escrito, que é um dos objetivos de uma escola bilíngue." 


\subsubsection{Modelos e Simulações}

Essa seção do questionário foi elaborada com respostas às seguintes perguntas:

“(4) Em sua opinião, a diferença entre os elementos da modelagem entidades e quantidades ficou clara para os alunos?"

“(5) Em sua opinião, os alunos surdos compreenderam a forma como os espaços quantitativos descrevem as variáveis qualitativamente?"

“(6) Qual foi sua impressão ao ver os alunos surdos trabalharem com simulações?”

“(7) Rodar simulações com os modelos ajuda a desenvolver em alunos surdos a compreensão do comportamento dos sistemas (isto é, da dinâmica dos sistemas)?"

Os resultados obtidos com as respostas para as perguntas 4 e 5 acima, não foram muito detalhadas pelos professores, sendo respondido por todos, que os alunos compreenderam e gostaram da representação nos modelos. Mas o que chamou atenção nos depoimentos foi que a maioria dos professores achou que os alunos não compreenderiam o que seria trabalhado com o auxílio da modelagem, por julgarem-na complexa demais. Porém, os resultados obtidos ao final de todo o processo, levou-os a reconhecer o potencial dos alunos surdos e da modelagem, como apresentado no trecho de entrevista a seguir:

\footnotetext{
"Mas ao longo do curso, em cada vez que eles tinham aula, eu percebia que eles estavam entendo cada vez melhor. No final, quando ocorreu o fechamento, eu vi que eles realmente entenderam e conseguiram acompanhar. E também que eles são capazes de compreender tudo isso sim."
}

Ao relatarem as impressões que tiveram ao verem os alunos surdos trabalhando com a modelagem, na questão 6, os professores se mostraram bastante entusiasmados com os resultados alcançados com o uso dessa ferramenta na educação de alunos surdos, confirmando o seu potencial de uso na educação.

\footnotetext{
“Apesar de no início os alunos terem se deparado com alguns problemas, à medida que eles foram tentando resolver e tirando as dúvidas, eles foram conseguindo entender. Os alunos foram muito participativos e interessados."
}

“Se fosse uma abordagem numérica, eu acho que eles não iriam gostar, mas como foi voltado para o quantitativo e o qualitativo, eles (alunos surdos) conseguiram e 
gostaram. Acredito que seja a melhor forma de se trabalhar com eles. Sendo melhor para desenvolver o raciocínio deles."

"Foi uma impressão boa, pois percebi uma total interatividade. Eles conseguiram fazer o que estava sendo proposto sem muitas dificuldades. Foi uma impressão muito boa."

Na questão 7, os professores apenas responderam que as simulações e os modelos ajudam os alunos surdos a compreender a dinâmica de um sistema sem argumentarem muito sobre como isso se dá.

\subsubsection{Usos na Educação}

Nessa seção, os professores puderam responder a perguntas relacionadas ao uso educacional da modelagem. As perguntas foram as seguintes:

“(8) Qual é a sua opinião geral sobre o curso e as atividades de aprendizagem que tivemos juntos com os alunos surdos?"

“(9) Por favor, comente o papel que modelos e atividades de modelagem poderiam ter na educação de alunos surdos em relação aos seguintes aspectos:
(a) desenvolvimento da linguagem sobre conceitos científicos
(b) desenvolvimento de novos conceitos
(c) esclarecimentos de conceitos já estudados
(d) capacidade de raciocinar
(e) desenvolvimento da capacidade de argumentar
(f) capacidade de julgar decisões, atividades, propostas"

"(10) Por favor, comente o papel que modelos e atividades de modelagem poderiam ter nas seguintes atividades pedagógicas:"
"(a) atividades interdisciplinares
(b) desenvolvimento de competências e habilidades
(c) atividades baseadas em projetos
(d) atividades que os alunos desenvolvem em laboratórios escolares" 
“(11) Quais são as principais dificuldades que você apontaria para levar a modelagem para a sala de aula? E as possíveis soluções para essas dificuldades?"

“(12) Em que disciplinas do currículo da educação básica você recomendaria o uso da modelagem qualitativa e de modelos de simulação?"

Ao relatarem suas impressões sobre a questão 8, os professores disseram ter achado o curso muito interessante, no qual os alunos participam ativamente da resolução de problemas sociais do cotidiano e propõe soluções a partir da análise e verificação desses, por meio do uso de modelos e das simulações geradas.

Também relataram a importância de se desenvolverem projetos que utilizem recursos adaptados à educação de alunos surdos, principalmente aqueles que envolvem uma abordagem visual, muito importante neste contexto.

“A gente viu que é um projeto em que eles se envolveram, sendo trabalhados temas que refletem problemas sociais e que precisam ser abordados.

Também vejo nestes projetos a importância de se trabalhar o visual, pois não havendo uma adaptação do material, ou uma metodologia voltada ao trabalho com alunos surdos, acaba não alcançando os objetivos propostos. "Nesse sentido, a metodologia aplicada no curso foi muito boa e adequada."

Porém, os professores acharam que o curso poderia ter uma duração maior e que deveriam se formar turmas menores, com o objetivo de se dar um atendimento mais exclusivo e mais lento, por julgar necessário quando se trabalha com alunos surdos.

"Eu achei a quantidade de alunos em sala grande, atrapalhando um pouco o desenvolvimento da aula, visto que a sala era muito pequena e que eles se desconcentram facilmente, necessitando de uma atenção mais individualizada. $\mathrm{O}$ curso também deveria ter uma duração maior, para que o ritmo fosse um pouco mais lento no desenvolvimento das atividades."

Os resultados obtidos com a questão 9, mostraram que a modelagem possui um potencial de uso relevante na educação científica de surdos por conter várias características singulares, entre elas: linguagem acessível e clara; conceitos trabalhados de forma simples; problemas que levam a reflexão da relação entre conceitos abordados em um sistema de 
interesse; poder reportar problemas sociais e ambientais; esclarecer conceitos já estudados; formar novos conceitos; estimular o raciocínio e a argumentação.

"Foi uma linguagem simples e clara, os conceitos científicos foram abordados de uma forma bem simples e que conseguiu o envolvimento dos alunos."

"Esses modelos apresentam um problema que leva os alunos a pensarem e questionarem, participando de uma forma bem lúdica, envolvendo questões sociais e levando os alunos a analisarem e proporem soluções para eles."

"Auxilia a compreender os conceitos trabalhados, pois eles são tratados de forma mais resumida, mais compactada, o que facilita o entendimento para o aluno surdo."

"A modelagem auxiliou os alunos a aprenderem novas palavras e os conceitos delas de uma forma bem diferente."

"Havia momentos que eu subestimava [os alunos], achando que eles não tinham entendido, mas quando era feita alguma pergunta, eles respondiam e explicavam com clareza do que se tratava. Eu achei fantástica a forma como eles argumentavam."

A questão 10 mostrou resultados muito bons nas possibilidades de aplicação da modelagem em atividades pedagógicas, principalmente no que se refere a atividades interdisciplinares.

\footnotetext{
"Daria para os professores trabalharem de várias formas. Desenvolver um projeto que envolvesse toda a escola, trabalhando a Geografia, a Ciências, a Matemática e outras disciplinas."

"Percebi que os alunos puderam melhorar a interpretação e a escrita, e as dificuldades em compreender algumas palavras eram superadas pelo interesse em entender o que significava a palavra que eles não sabiam.”
}

Os professores apresentaram suas opiniões sobre as principais dificuldades em levar a modelagem para a sala de aula e as possíveis soluções na questão 11. Os resultados apontaram para uma necessidade de as escolas se modernizarem com a presença de laboratórios de informática com equipamentos modernos, que passem por manutenção periódica e que contem com um apoio técnico constante para o controle e suporte a atividades desenvolvidas 
nesse ambiente. Também relataram a necessidade de um envolvimento maior por parte dos professores nas atividades pedagógicas desenvolvidas na escola, exigindo que haja cursos de formação continuada para os discentes e planejamento adequado das atividades desenvolvidas, principalmente quando se trabalha com alunos surdos, que precisam de adequações para um desenvolvimento correto das atividades.

"Precisa que o professor entenda a importância do preparo do material para trabalhar com alunos surdos, principalmente no que se refere à adaptação visual do material. É necessário também, que se tenha toda a estrutura de computadores já montada, com o sistema e tudo que se faz necessário para o trabalho."

Os professores responderam à questão 12 recomendando o uso de modelos e simulações nas disciplinas de Ciências, Geografia e Português, sendo que essa últimaseria trabalhada de forma interdisciplinar com a produção de textos explicativos sobre o conteúdo dos modelos, ou de forma contrária, partindo-se dos textos para a construção de modelos. Em Salles (2004 e 2005), assim como em Feltrini (2009) e Resende (2010), esse tipo de atividade foi verificada, apresentando muito sucesso na elaboração de textos e de argumentações contendo respostas não triviais dos alunos analisados.

\subsubsection{Software DynaLearn}

Os resultados obtidos com a análise das respostas às perguntas abaixo listadas mostraram que os professores ainda se sentem inseguros para trabalhar com a Modelagem Qualitativa em suas aulas, mesmo porque eles só tiveram um contato mais prolongado com essa ferramenta durante o curso ministrado aos alunos, o que é pouco para que eles se apropriem desse conhecimento de modo a utilizá-la.

“(13) Como você avalia a experiência de se trabalhar com o software ? Quais foram as vantagens e as dificuldades que você identificou para que os professores utilizem o DynaLearn com seus alunos?"

“(14) Como você avalia a importância de construir modelos específicos em diferentes níveis de complexidade no DynaLearn para os alunos surdos?"

“(15) Que nível de complexidade do DynaLearn (LS2 ou LS6) você considera que mais contribui para o aluno surdo compreender conceitos representados em modelos qualitativos?" 
“(16) O que você acha que a modelagem com o DynaLearn oferece a você, como professor, se tiver que ensinar aos surdos sobre os efeitos do Desmatamento e da Regeneração da vegetação?”

A questão 13 apresentou respostas que remetem a utilização vantajosa do softwareDynaLearn, levantando seus potenciais no uso educacional por ser dinâmico e conter recursos visuais importantes para a educação científica de alunos surdos.

\footnotetext{
"Percebi que os modelos e o software utilizados são bem dinâmicos e trazem recursos visuais que levam clareza ao entendimento pelos alunos surdos, possibilitando que eles manejem os modelos e também criem os seus próprios. Por poder ser utilizado com outras disciplinas, torna-se uma ferramenta muito importante no ensino."
}

"Eu achei fácil o entendimento de tudo, porém depende muito do querer do professor para conseguir aplicá-lo em sala."

Na questão 14, os entrevistados consideraram importante a construção de modelos em níveis específicos de complexidade, pois acham que dessa forma é possível estabelecer uma gradação na complexidade do que esta sendo trabalhado.

\footnotetext{
"Pelo que vivenciei, acho que ajuda o aluno a raciocinar e ai ele vai seguindo os passos e vai visualizando as situações. Ou seja, vai aumentando a complexidade, sendo importante pra trabalhar o conhecimento de forma gradativa."
}

Como havia sido abordado fragmentos de modelos em LS6, a questão 15 trouxe uma importante discussão de qual nível seria melhor para trabalhar os modelos com os alunos, os resultados apresentados mostraram-se o contrário do esperado, pois os professores achavam mais completos os modelos em LS6 e disseram haver maiores possibilidades de uso desses em relação ao LS2, indo contra a hipótese desta pesquisa.

“O LS2 pode ajudar a se chegar no LS6, mas o LS6 possibilitaria que eles compreendessem melhor os conceitos trabalhados."

Na questão 16, novamente os professores se mostraram inseguros em trabalhar com o DynaLearn e a modelagem em sala, relatando que a principal contribuição foi a forma diferente de pensar e de ter uma ferramenta a mais de apoio ao ensino. 
"Seria uma ferramenta a mais para se utilizar em sala, sendo válida para o desenvolvimento da argumentação e o aprendizado. Mas precisaria ter um maior contato com ela para poder falar algo de concreto."

"Trouxe-me uma visão mais ampla de se trabalhar de uma forma mais criativa e motivadora com alunos surdos."

\subsubsection{Questões abertas}

A parte final do questionário foi composta por questões abertas em que os professores puderam falar livremente sobre suas impressões gerais do curso e de tudo que ocorreu durante os encontros. Para isso eles responderam as seguintes questões:

“(17) De que você gostou?"

“(18) De que você não gostou?"

“(19) Alguma ideia para melhorar o software?"

“(20) Você tem algum outro comentário?"

Os primeiros relatos apresentaram as características do curso e da modelagem que mais gostaram. Sendo apresentados na questão 17 aspectos positivos referentes à abordagem do curso e da forma como a LIBRAS foi trabalhada, elogiando o domínio dessa linguagem por parte dos discentes envolvidos. Para eles, a metodologia foi adequada, alcançou os objetivos propostos e possibilitou uma interação dos alunos. Gostaram também da forma como os alunos se empolgaram com as atividades e a maneira detalhista como os conceitos eram abordados.

Porém na questão 18 , eles relatam que não gostaram da quantidade de alunos, pois consideraram a turma formada muito grande. Também não gostaram da duração do curso, por considerarem muito corridas as atividades desenvolvidas. Porém, o tempo disponibilizado pela escola e a participação dos alunos foi fato relevante para que o curso ocorresse dessa maneira, sendo proposto, que em uma nova oportunidade, esses problemas sejam 
considerados, para que não ocorra o mesmo com a execução de novos cursos com essa abordagem.

A questão 19 foi marcada pela abstenção de sugestões por parte dos entrevistados, sendo argumentado que tiveram pouco contato com o software e que não teriam argumentos para propor algo relevante.

Ao final, na pergunta 20, os professores teceram comentários de agradecimento e se mostraram interessados em continuar a terem novas experiências com a modelagem e se possível levarem esses conhecimentos para a sala de aula, buscando aplicar junto aos alunos o que foi trabalhado no curso.

\footnotetext{
"Eu gostaria de agradecer muito a todos os professores que estiveram aqui e achei fantástica a forma como foi abordado os conceitos e a dedicação dos envolvidos. Os alunos gostaram muito. Ficaram muito gratos e eu também.”

"Foi muito bom para os alunos participarem desse curso, sendo muito importante para a construção do conhecimento. Foi um diferencial, pois o que as pessoas trazem de novo aqui sempre é muito válido."
}

\subsection{Resultados da análise do 'MATERIAL INSTRUCIONAL'}

O Material Instrucional (SALLES et al., 2013), produzido pelo Projeto LAPEVI e analisado no presente trabalho, possui três capítulos, sendo que os dois últimos foram os que mais contribuíram para a elaboração do material utilizado na presente investigação, inclusive como fonte de imagens e de atividades.

O material mostrou-se ferramenta útil na aquisição de conceitos científicos relacionados ao tema Ecologia por alunos surdos, por apresentar uma diagramação visual bem atrativa e entendível, com a presença de imagens e de modelos que se relacionavam de forma explicativa.

A abordagem do raciocínio dedutivo explorada nos modelos e nos exercícios fornecia o estímulo à participação do aluno no processo de construção do conhecimento de forma ativa.

O material como um todo possibilita uma vasta amplitude de utilização dentro de um contexto de educação inclusiva e de um trabalho interdisciplinar, inclusive servindo como 
estímulo à produção de textos, e a trabalhos com o Português escrito, a segunda língua dos surdos, de uma forma mais atrativa e dinâmica.

Os exercícios serviram para verificar o potencial dos alunos em fazer inferências e a compreensão da dinâmica dos sistemas apresentados nos modelos.

Já o uso dos modelos presentes no 'Manual Instrucional', mostrou-se bastante complexo, porém servindo como arcabouço para a construção de modelos mais simples a partir do uso dos fragmentos de modelos e dos cenários presentes no mesmo.

Sugiro que este material seja novamente avaliado e proponho que os modelos nele contido sejam convertidos em modelos mais simples, como forma adicional aos lá apresentados, buscando reduzir as dificuldades de compreensão do modelo como um todo.

Com o trabalho de pesquisa desenvolvido, foi possível verificar as potencialidades do uso dos modelos comprovando a hipótese e alcançando os objetivos propostos neste estudo de caso, pois foi introduzida a Modelagem Qualitativa dentro de um contexto de Educação Bilíngue de maneira simples e atrativa na forma de um curso, promovendo a aprendizagem de conceitos científicos e o desenvolvimento do raciocínio hipotético-dedutivo por alunos surdos. Os resultados positivos obtidos se repetiram ao analisar as opiniões de professores sobre benefícios e dificuldades para introduzir a Modelagem Qualitativa na sala de aula, sendo que os mesmos acharam a abordagem adequada e bem interessante para se trabalhar inclusive de forma interdisciplinar, permitindo uma maior interação entre a escola e os alunos. Também foi possível avaliar material didático disponível para ensino de ciências apoiado por modelos qualitativos na utilização do 'Manual Instrucional' que se mostrou bastante adequado e útil como ferramenta de ensino de ciências para alunos surdos por contemplar aspectos importantes da pedagogia visual, essencial ao ensino de alunos surdos.

Por fim, será construída uma proposta de curso de ensino de ciências apoiada por modelos qualitativos para alunos surdos. 


\section{5- DISCUSSÃO}

O presente trabalho dá continuidade a esforços despendidos nos últimos 10 anos no sentido de explorar o potencial dos modelos qualitativos na educação de estudantes surdos. Com efeito, as principais linhas seguidas incluem o aprendizado de conceitos científicos (particularmente, ecológicos), o desenvolvimento do raciocínio hipotético-dedutivo e da capacidade de fazer inferências e a produção de materiais didáticos voltados para a comunidade surda. Nesta seção, os resultados do presente trabalho serão discutidos à luz das experiências anteriores.

Nessa pesquisa, assim como em Salles et al. (2004), os alunos surdos foram capazes de fazer inferências e interagir com os conceitos abordados, criando previsões e propondo possíveis soluções aos problemas representados nos modelos. Os alunos demonstraram que aprenderam conceitos representados em modelos qualitativos e realizaram inferências a partir de modelosmais simples apresentados a eles, dentro de uma abordagem pedagógica visual adequada à exploração de seus sistemas compensatórios.

Assim como em Salles et al. (2005), os resultados anteriores obtidos em Salles et al. (2004), foram confirmados, acrescentando-se a isso a verificação da capacidade de os alunos surdos fazerem inferências a partir de modelos qualitativos. Essa comprovação se deu pela análise de questionários e atividades feitas por alunos surdos que participaram do curso, em que se explorou o uso de modelos qualitativos mais simples e explicados com o auxilio de imagens previamente selecionadas do material pedagógico desenvolvido pelo LAPEVI.

Em Salles et al. (2005) os resultados foram analisados aplicando-se a abordagem descrita em Sperber e Wilson (1995), pela qual se verificou haver maior presença de respostas contendo conclusões não-triviais, que são conclusões construídas a partir da produção de inferências sobre conhecimentos prévios, do que por meio de conclusões triviais, aquelas em que repete-se apenas as informações presentes no material analisado. Nas conclusões deduzidas após a formação de hipóteses que favorecem o processamento de suposições por meio de conceitos (NUNES, 2012).Ou seja, o aluno precisa de um conjunto de informações e conceitos guardados em sua memória que se relacionam direta e indiretamente e a partir de um esforço mental de raciocínio e de dedução, ele é capaz de combinar essas informações para então gerar hipóteses sobre a relação entre os objetos, o que apoia a teoria de que materiais com base em RQ auxiliam o desenvolvimento de habilidades de raciocínio lógico nos alunos surdos. O experimento como um todo teve resultados positivos, pois os alunos 
apresentaram mais conclusões não-triviais, porém, mesmo com esses resultados, a comunicação ainda é uma problemática bastante complexa quando se fala de educação de surdos.

Também em (SALLES et al., 2005), o desempenho linguístico dos alunos foi discutido em termos de relevância, como feito por Sperber \& Wilson (1995), na qual a informação modifica e melhora uma representação total do mundo.

"Em que a representação do mundo pode ser considerada como um depósito de pressupostos factuais em que cada nova suposição factual adquirida é combinada com o estoque de suposições existentes, que o leva a formular inferências, cujo objetivo é modificar e melhorar no indivíduo sua compreensão e representação do todo que o cerca, ou seja, a representação e compreensão do mundo como um todo. Suposições factuais são representações armazenadas na memória e tratadas como descrições verdadeiras do mundo, que podem ser adquiridas por quatro fontes diferentes: percepção, decodificação linguística, suposições e deduções. As melhorias na representação do mundo são rastreadas pelo funcionamento do dispositivo dedutivo humano, em que as propriedades semânticas refletem-se pela forma de suposições. Para os autores, o dispositivo dedutivo humano tem acesso somente a regras de eliminação e os rendimentos apenas conclusões não-triviais."

(LIMA-SALLES, H.; SALLES, P.; BREDEWEG, B., 2005)

Apesar de as análises das respostas dos questionários terem mostrado que os alunos foram capazes de dar mais respostas em que as inferências estavam presentes, o corrente trabalho não fez uma análise quantitativa mais complexa que comprovasse a produção de conclusões não triviais. Porém, em uma análise qualitativa, foi possível verificar que os alunos gostaram da modelagem qualitativa para aprender, conseguiram dar respostas elaboradas sobre os temas abordados e responderam questionários em que se faziam presentes várias afirmativas que exploravam o uso de silogismos. Ou seja: os alunos conseguiram responder afirmações qu não estavami evidentes por meio do uso de seu raciocínio. Porém, a linguagem e a ausência de sinais para muitos termos científicos ainda é um problema a ser superado para uma melhor compreensão dos conceitos e para que os surdos possam interagir plenamente com os modelos. 
Com base nesses resultados e dentro desta problemática, Feltrini (2009) criou, juntamente com a comunidade surda, sinais para conceitos importantes para a compreensão de sistemas dinâmicos representados em modelos qualitativos, que foram utilizados no desenvolvimento deste trabalho. Alguns conceitos são de fundamental importância para a compreensão da dinâmica de sistemas representados por meio de modelos, tais como: entidades, quantidades, processo, influências, derivada, magnitude, configuração, espaço quantitativo, correspondência, proporcionalidade, pressupostos, agente, cenário, simulação, entre outros conceitos que fazem parte de um Glossário de LIBRAS/ Português presentes em seu trabalho e que também faz parte dos apêndices contidos no final desse trabalho. Além disso, Feltrini (2009) criou um DVD didático, contendo: o modelo “Árvore e Sombra” e um modelo complexo "Aquecimento Global”; atividades com níveis de complexidade gradativa acerca dos modelos; um Glossário de LIBRAS/Português, que auxilia na comunicação e no entendimento dos elementos de modelagem e também vídeo aulas sobre como modelar e utilizar modelos complexos para aprender conceitos ecológicos, apresentadas com o uso de sinais desenvolvidos para os termos típicos usados em Modelos Qualitativos (MQ). Esse material foi utilizado para introduzir a modelagem nas aulas iniciais do curso, mostrando-se ferramenta útil na educação científica bilíngue de surdos. Tal fato foi comprovado com os resultados obtidos nas atividades 1 e 2, e na análise estatística obtida com os desempenhos do pré e pós teste, em que os alunos conseguiram compreender o que estava sendo proposto, com isso, deram mais respostas assertivas e apresentaram uma melhora no uso do raciocínio hipotético dedutivo após a intervenção feita durante o curso de introdução a MQ.

Também foram realizados testes estatísticos paramétricos e não paramétricos para verificar a hipótese de o uso dos modelos serem eficientes para a compreensão de fenômenos ecológicos e do aprimoramento do RQ

De particular interesse para o presente trabalho, foi a dissertação de mestrado defendida no Programa de Pós-graduação em Ensino de Ciências por Resende (2010). Neste trabalho, a autora utilizou o DVD sobre modelos qualitativos (FELTRINI, 2009), junto a alunos surdos e a professores de educação básica que trabalham com surdos. Em relação ao desempenho dos alunos, seus estudos foram conclusivos, demonstrando que os alunos que usaram modelos qualitativos, obtiveram melhor resultado em testes sobre conteúdos de ecologia e na capacidade de raciocinar dedutivamente diante de problemas apresentados a eles, do que os grupos controle, que não fizeram uso dos mesmos recursos. Resultados esses comprovados por essa pesquisa pela análise das atividades e dos testes aplicados aos alunos surdos. 
Os resultados obtidos com as entrevistas realizadas com os professores/intérpretes comprovam os resultados de pesquisas anteriores, pois apresentam resultados semelhantes aos dos questionários aplicados por Resende (2010), mostrando que os professores foram favoráveis ao uso de modelos qualitativos em atividades educacionais, pois concordam que os mesmos permitem a interrelação de objetos de conhecimentos diferentes, possibilitando o desenvolvimento de projetos interdisciplinares e a exploração de habilidades de desenvolvimento do RQ nos alunos. Essa dissertação procurou utilizar questionário semelhante para verificar as opiniões dos intérpretes e professores que auxiliaram o curso e os resultados de Resende (2010) foram confirmados. Os professores gostaram da metodologia e afirmaram ser ferramenta útil na educação científica não somente de alunos surdos, mas também de alunos ouvintes.

De acordo com as respostas das entrevistas, os problemas descritos nas pesquisas anteriores, também foram detectados nesse trabalho. A resistência no uso de ferramentas tecnológicas e as dificuldades técnicas em se usar computadores com os alunos em sala ainda é um problema a ser superado. A formação continuada de professores e investimentos em recursos tecnológicos nas escolas poderiam minimizar um pouco dessas dificuldades, mas somente essas ações, sem o envolvimento dos professores e dos membros da comunidade escolar, não resolveriam as deficiências encontradas para se utilizar de forma efetiva e produtiva as ferramentas computacionais disponíveis para se trabalhar a modelagem com os alunos. 


\section{6- CONSIDERAÇÕES FINAIS}

Durante o curso piloto desenvolvido junto aos alunos surdos, foi possível verificar que a utilização de modelos qualitativos no nível LS2 por meio da execução de atividades explorando silogismos e o raciocínio dedutivo, mostrou-se ferramenta eficaz na educação científica de alunos surdos no aprendizado de conceitos relacionados a temas ligados a Ecologia. Essa verificação foi feita por meio da execução de 4 atividades que utilizavam afirmativas do tipo "Se ... Então..", frases que deveriam ser completadas com "Aumenta", ou "Diminui” e pela atividade de completar modelos com sinais (+) e (-), que indicavam a influência positiva ou negativa entre as quantidades representadas no sistema estudado. Também foram feitas análises estatísticas comparando o Pré e Pós-teste ao nível de 5\%, buscando dar maior acurácia à análise qualitativa dos dados e sustentar com mais argumento a hipótese de que os modelos qualitativos contribuem para o desenvolvimento do raciocínio dedutivo. Resultados semelhantes foram obtidos a partir da análise das impressões dos professore/intérpretes colhidas por entrevistas realizadas ao final do curso. Todos os resultados apontaram que o uso da Modelagem Qualitativa dentro de um contexto de Educação Bilíngue de forma simples e atrativa promove a aprendizagem de conceitos científicos e o desenvolvimento do raciocínio hipotético-dedutivo por alunos surdos.

Os professores entrevistados mostraram-se bastante otimistas quanto as possibilidades de utilização da MQ, inclusive de forma interdisciplinar, porém há uma necessidade de verificação dessa possibilidade em estudos futuros.

O material didático utilizado e avaliado, 'Manual Instrucional' possibilitou a criação e desenvolvimento de atividades que foram fundamentais para o desenvolvimento deste trabalho de pesquisa contemplando aspectos relevantes da pedagogia visual e atendendo às necessidades dos alunos surdos.

Diante do exposto, apresento nesse trabalho de Dissertação a ser defendida no Programa de Pós-graduação em Ensino de Ciências, proposta para a criação de um curso para alunos surdos do Ensino Médio, utilizando o (RQ) buscando demonstrar como explorar modelos qualitativos focando apenas em tópicos essenciais para o ensino e a aprendizagem de alunos surdos com o uso de um material didático preparado pelo projeto LAPEVI, adaptando os modelos a um nível mais simples,buscando reduzir o tempo de apropriação das primitivas de modelagem e proporcionando o desenvolvimento do raciocínio hipotético-dedutivo nos alunos, de forma atrativa e descomplicada. 
O curso desenvolvido possui atividades que podem ser alteradas, acrescentando-se ou retirando-se partes às quais o professor julgar necessárias. Ou seja, o material desenvolvido para proposta de curso, disponível de forma independente desta Dissertação. pode ser utilizado na íntegra ou alterado de acordo com o ritmo/nível da turma ou do professor. Com isso, o mediador pode se sentir a vontade para realizar as alterações de modo a tornar mais eficaz o uso desse material e, assim, desenvolver atividades capazes de promover atividades capazes de estimular o raciocínio dos alunos de acordo com suas próprias necessidades. 


\section{REFERÊNCIAS BIBLIOGRÁFICAS}

BARDIN, L. Análise de Conteúdo. Lisboa, Portugal; Edições 70, LDA, 1995.

BICUDO, F.A entrevista- testemunho: quando o diálogo é possível. Revista Caros Amigos. 2006. Disponível em:<http://observatorio.ultimosegundo.ig.com.br/artigos.asp?cod=333DAC OO1. Acesso em 10-12-2014.

BREDEWEG, B; BOUWER, A; JELLEMA, J; BERTELS, D; LINNEBANK, F; LIEM,J. Garp3 - A new workbench for qualitative reasoning and modelling. In: 20TH INTERNATIONAL WORKSHOP ON QUALITATIVE REASONING (QR06), Proceedings of the 20th international workshop on qualitative reasoning (QR06), BAILEY-KELLOGG, C; KUIPERS, B. (Eds.), p. 21-28, 2006.

BREDEWEG, B.; LIEM, J.; BEEK, W.; LINNEBANK, F.; GRACIA, J.; LOZANO, E.; WIBNER, M.; BÜHLING, R.; SALlES, P.; NOBLE, R.; ZITEK, A.; BORISOVA, P.; MIODUSER, D. - An Intelligent Learning Environment for Learning Conceptual Knowledge. AI Magazine, 34 (4): p. 46-65, $2013 . \quad$ Em: http://dx.doi.org/10.1609/aimag.v34i4.2489, acessado em: 13/02/2014.

CALlEGARI-JAQUES, S. M., Bioestatística- Princípios e Aplicações, Porto Alegre: Artmed, p.166-167,170-173,239, 2003.

CARRETERO, M. (1979). Por qué flotan las cosas? El Desarrollo del Pensamiento Hipotético Deductivo y la Ensenanza de la Ciencia. Infancia y Aprendizaje, n.8, p.7-22.

CARVALHO, A. M. P. Critérios estruturantes para o ensino de ciências. In: CARVALHO, A. M. P. (Org.). Ensino de ciências: unindo a pesquisa e a prática. São Paulo: Pioneira Thomson Learning, 2004.

COELHO, C. M. M. Inclusão escolar. In: Desenvolvimento Humano,Educação e Inclusão Escolar. Brasília, 2010. 
COSTA, M. F. G.“Estudo biomecânico do ouvido médio”. Dissertação apresentada à Faculdade de Engenharia da Universidade do Porto, para obtenção do grau de Doutor em Ciências de Engenharia. p. 92-94. Porto,Janeiro de 2008.

FALCÃO, T. R.; TÉNIES, J. Sobre os métodos quantitativos na pesquisa em ciências humanas: riscos e benefícios para o pesquisador. Revista Brasileira de Estudos Pedagógicos, v. 81, n. 198, p. 229-243, 2000.

FELTRINI, G. M. Aplicação de Modelos qualitativos à Educação Científica de Surdos.Brasília, 2009. 222 f. Dissertação (Mestrado em Ensino de Ciências). Instituto de Ciências Biológicas, Universidade de Brasília.

FELTRINI, G. M.; GAUCHE, R. Ensino de ciências a estudantes surdos: pressupostos e desafios. In: VI ENCONTRO NACIONAL DE PESQUISA EM EDUCAÇÃO EM CIÊNCIAS (VI ENPEC), 2007, Florianópolis -SC. Atas do VI ENPEC. Florianópolis-SC, 2007.

FORBUS, K.D. Qualitative Process Theory. Artificial Intelligence, n. 24, 85-168, 1984.

FUJISAWA, D. S. Utilização de jogos e brincadeiras como recurso no atendimento fisioterapêutico de criança: implicações na formação do fisioterapeuta. 2000. Dissertação (Mestrado em Educação)- Faculdade de Filosofia e Ciências, Universidade Estadual Paulista, Marília, 2000.

GERIR, . Pedagogia de projetos, Salvador, v. 9, n² 29, p. 17-37, Jan./ fev. 2003. Disponível em: http/www.liderisp.ufba.br/módulos/pedagproj.pdf . Acesso em 12 de julho de 2015.

GIL, A. C. Como elaborar projetos de pesquisa. 4. ed. São Paulo: Atlas, 2002.

GONZÁLEZ REY, F. L. El aprendizage em El enfoque histórico e cultural: sentido y aprendizaje. In: Arante E. Et. Al. (Ed.) Concepções e práticas em formação de professores. Rio de Janeiro: DP\&A, 2003. 
KELMAN, C. A. Aqui tudo é importante: Interação de alunos surdos com professores em espaço escolar inclusivo. Tese de doutorado. Instituto de Psicologia. Universidade de Brasília, 2005.

KELMAN, C. A; TUXI, P. Intérprete educacional ou professor? A atuação profissional do intérprete da língua de sinais no ensino de Ciências. In: SALLES, P. B. A. e GAUCHE, R. (Org.). Educação Científica, Inclusão Social e Acessibilidade. 1 ${ }^{\mathrm{a}}$ ed. Goiânia: Cânone Editorial, p.79-103, 2011.

LACERDA, C. B. F.; MANTELATTO, C. B. F. de. As diferenças concepções de linguagem na prática fonoaudiológica. In: LACERDA, C. B. F.de; NAKAMURA, H.; LIMA, M. C. (org.). Fonoaudiologia, surdez e abordagem bilíngue. São Paulo: Plexus, 2000.

LAGE, N. A reportagem: teoria e técnica de entrevista e pesquisa jornalística. Rio de Janeiro: Record, 2001.

LAVILLLE, C., DIONNE, J. A construção do saber: manual de metodologia da pesquisa em ciências humanas. Tradução Heloisa Monteiro e Francisco Settineri.-Porto Alegre: Artmed; Belo Horizonte: Editora UFMQ 1999. Reimpressão 2008.

LUCHESI, M. R. C. Educação de pessoas surdas: experiências vividas, histórias narradas. Campinas: Papirus, 2003.

MARCONI, M. de A., LAKATOS, E. M. Fundamentos de metodologia científica. 5. ed. São Paulo: Atlas, 2003

MARTINHO, A. C. F.; SANTOS, R. P. Avaliação da audição em crianças. In: Deficiência Auditiva: conversando com familiares e profissionais da saúde. São José dos Campos: Pulso, 2005.

MATOS, M. A. E. A metodologia de projetos, a prendizagem significativa e a educação ambiental na escola. Dissertação de mestrado em Ensino de Ciências. Universidade Federal de Mato Grosso do Sul, 2009. Publicado em: Ensino, Saúde e Ambiente, v. 2 n. 1, p. 22-29, abril, 2009. 
MOREIRA, M. A. Aprendizagem significativa. Brasília. Editora Unb, 1999.

NUNES, E. K. A construção de sentido de um enunciado pela Teoria da Relevância: uma abordagem do significado na interface semântico/pragmática. Revista Liberato, Novo Hamburgo, v. 13, n. 20, p. 01-134, 2012.

OLIVEIRA, E.; ENS, R. T.; ANDRADE, D. B. S. F.; MUSSIS, C. R. Análise de conteúdo e pesquisa na área da educação. Revista Diálogo Educacional, Curitiba, v. 4, n. 9, p. 11-27, 2003.

PATTON, M. Q. Qualitative Evaluation and Research Methods. London: SAGE; 1990.

PIAGET, J. e INHELDER, B. De la Lógica de Niño a la Lógica del adolescente. Buenos Aires: Paidós, 1967. (Tradução de: De la Logique de $1^{\text {a }}$ enfant a la logique de L’adolescent, 1955).

PRETTI, D.; URBANO, H. A linguagem falada culta na cidade de São Paulo. São Paulo: Queiroz, 1988.

QUADROS, R. M. O tradutor e intérprete de língua brasileira de sinais e língua portuguesa. Secretaria de Educação Especial; Brasília: MEC; SEESP, 2007.

QUEIROZ, E.F.e KELMAN C.A.. "Implicações do implante coclear no processo de aquisição da escrita de uma criança surda.". In: As necessidades educacionais especiais: altas habilidades, transtornos globais do desenvolvimento e deficiências. Londrina: EdUEL (2009).

RESENDE, M. M. P.,Avaliação do uso De Modelos Qualitativos como Instrumento Didático no Ensino de Ciências para Estudantes Surdos e Ouvintes. Brasília, 2010. 162 f. Dissertação (Mestrado em Ensino de Ciências). Instituto de Ciências Biológicas, Universidade de Brasília.

ROJAS, J. E. A. O indivisível e o divisível na história oral. In: MARTINELLI, M. L. Pesquisa qualitativa: um instigante desafio. São Paulo: Veras, 1999. p. 87-94. 
SALLES, P.GAUCHE, R. e VIRMOND, P. (2004) A Qualitative Model of Daniell Cell for Chemical education of deaf students: scientific education and acquisiton of Portuguese as a second language. In: LESTER, J.C.; VICARI, R.M.; PARAGUAÇU, F. (eds.) Intelligent Tutoring Systems: 7thInternational Conference, ITS 2004, Proceedings. Série Lecture Notes in Computer Science, vol. 3220, pp. 870-872, Berlim - Heidelberg, Springer Verlag.

SALLES, P.; LIMA-SALLES, H. M. M.; BREDEWEG, B. (2005) The Use of Qualitative Reasoning Models of Interactions Between Populations to Support Causal Reasoning of Deaf Students. In: LOOI, C.-K.; MCCALLA, G.; BREDEWEG, B., BREUKER, J. (eds.) Artificial Intelligence and Education: Supporting learning through Intelligent and Socially Informed Technology. Amsterdam, IOS Press / Omasha, pp. 579-586, 2005.

SALLES, P.; LIMA-SALLES, H. M. M.; CHAN, A. C. V. Formulação de inferências e propriedades da interlíngua dos surdos. In: LIMA-SALLES, H. M. M. (org.). Binliguísmo dos surdos: questões linguísticas e educacionais. $1^{\text {a }}$ Ed. Goiânia: Canone Editorial, 2007, p. $97-$ 118.

SALLES, P.; FELTRINI, G. RESENDE, M.; LIMA-SALLES, H.Modelos Qualitativos para o Ensino de Ciências de alunos surdos do Ensino Médio.Manual Instrucional.Brasilia: Universidade de Brasília, Projeto LAPEVI, 2013. 109 p. (Manuscrito não publicado).

SAllES, P.; SOUZA, A.; NOBLE, R.; ZITEK, A.; BORISOVA, P.; LEIBA, M.; BREDEWEG, B. DynaLearn curriculum for environmental science. DynaLearn Project, EC FP7 STREP project 231526, Deliverable D6.5, 2012.

SCHRAIBER, L. B. Pesquisa qualitativa em saúde: reflexões metodológicas dorelato oral e produção de narrativas em estudo sobre a profissão médica. Revista de Saúde Pública, São Paulo, v. 29, n. 1, p. 63-74, 1995.

SIEGEL, S. Estatística não-paramétrica: para as ciências do comportamento. Tradutor: Alfredo Alves de Farias. Ed. McGraw-Hill do Brasil Ltda, 1977.

SILVA, M. A.; SILVA, L. C.; MION, R. A. A prática inclusiva no ensino de física para portadores de deficiência auditiva. In: IV ENCONTRO NACIONAL DE PESQUISA EM 
EDUCAÇÃO EM CIÊNCIAS (IV ENPEC), 2003, Bauru-SP. Atlas do IV ENPEC. Bauru-SP, $2003 \mathrm{a}$

SPERBER, D.; WILSON, D. Relevance: communication and cognition. Oxford (UK) and Cambridge (Mass): Blackwell Publishers Ltda, 1995.

TUXI, P. A atuação do intérprete educacional no Ensino Fundamental. 2009. Dissertação. (Mestrado em Educação) - Faculdade de Educação da Universidade de Brasília, Universidade de Brasília, 2009.

VIEIRA, Sônia. Introdução a Bioestatística, 4ª Ed, Rio de Janeiro,Ed Elsevier, p.272-276,335, 2008).

VYGOTSKY, L. S..A formação social da mente. 4 ed. São Paulo: Martins Fontes, 1991.

VYGOTSKY, L. S. Pensamento e linguagem. São Paulo: Martins Fontes, 1998.

VYGOTSKY, L. S. A contstrução do pensamento e da linguagem. São Paulo: Martins Fontes, 2001.

WELD, D. \& de KLEER, J (Eds.) Readings in Qualitative Reasoning about Physical Systems. San Mateo, CA: Morgan Kaufmann, 1990.

YAMADA, M.O.; BEVILACQUA, M.C. O papel do psicólogo no programa de implante coclear do hospital de reabilitação de Anomalias Craniofaciais. Periódico (s) Estudos de Psicologia. Campinas: PUC, 2005. V. 22.

YIN, R. Estudo de Caso. Planejamento e Métodos. Porto Alegre: Bookman, 2005.Volume 15, julho a dezembro de 2005. 


\section{APÊNDICES}

\section{APÊNDICE A - Glossário}

Entidades = objetos envolvidos no sistema (ex.: árvore, solo).

Configurações = descrição da relação entre entidades (ex.: árvore sobre solo).

Quantidades = variáveis que representam propriedades das entidades (ex.: biomassa de árvore; área de sombra do solo).

Valores qualitativos de quantidades = valores qualitativos que as variáveis podem assumir. Consistem de magnitude (tamanho da quantidade; ex. pequena) e derivada (direção de mudança; ex. crescendo). (Exs.: <pequeno, crescendo>; <grande, estável>).

Espaços quantitativos = conjunto de possíveis valores qualitativos de uma quantidade (ex. \{zero, pequeno, médio, grande\} ou zpmg; \{minus, zero, plus\} ou mzp).

Processo = mecanismo que determina alguma mudança no sistema. Nos modelos que estamos estudando, parte-se do pressuposto de que todas as mudanças começam em processos (por meio de influências diretas) e se propagam para outras quantidades do sistema (por meio de proporcionalidades).

Influências diretas ( $\mathrm{I}+, \mathrm{I}-$ ) = representação de direção da causalidade (o sentido da seta) e de função matemática, em que o valor da quantidade taxa é somado ou subtraído do valor da quantidade influenciada; representação de PROCESSOS. (Ex.: taxa de crescimento $-(\mathrm{I}+) \rightarrow$ biomassa).

Proporcionalidades qualitativas $\left(\mathrm{P}+, \mathrm{P}_{-}\right)$= representação de direção da causalidade (o sentido da seta) e de função matemática segundo a qual a derivada da quantidade influenciada torna-se igual à da quantidade influenciadora $(\mathbf{P}+)$, ou contrária à da quantidade influenciadora $(\mathbf{P}-)$. Propaga os efeitos dos processos para outras quantidades. (Exs.: biomassa $-(\mathrm{P}+) \rightarrow$ área de sombra; área de sombra $-(\mathrm{P}-) \rightarrow$ temperatura).

Correspondências $(\mathrm{Q}, \mathrm{V})=$ representação de valores que ocorrem simultaneamente em duas quantidades. Podem relacionar valores isolados $(V)$ ou todo o espaço quantitativo $(Q)$. (Ex.: zero $-(V) \rightarrow$ zero; zpmg $-(\mathbf{Q}) \rightarrow$ zpmg).

Cenários = descrição de uma situação do sistema a partir da qual o simulador qualitativo vai iniciar uma simulação. Contém a descrição da estrutura do sistema (entidades e configurações) e valores iniciais de algumas quantidades.

Estado do sistema = situação qualitativamente distinta em que o sistema pode ser encontrado, com duração de certo intervalo de tempo, durante o qual cada quantidade têm certo valor. (Ex.: os estados iniciais e os estados finais de uma simulação).

Grafo de estados / de comportamento = diagrama que representa todos os estados qualitativos possíveis do sistema durante uma simulação, e as possíveis transições entre eles. (Ex.: simulação que produz 10 estados: $[1,2,3,4,5,6,7,8,9,10])$.

Comportamento do sistema = sequências de estados qualitativos, que mostram como o sistema muda ao longo do tempo. O grafo de estados representa todos os comportamentos possíveis dado o cenário inicial.

Trajetória do sistema = Cada uma das sequências de estados qualitativos que representam um possível caminho dentro do comportamento do sistema. (Ex.: estados $[1,2,4,5]$, desde que exista pelo menos uma transição entre estado 1 e 2; entre 2 e 4; entre 4 e 5).

Diagramas de valores das quantidades = representações dos valores que as quantidades podem assumir durante uma simulação, em uma trajetória ou na simulação completa.

Modelo causal = diagrama representando todas as entidades, quantidades, relações causais (I, P), correspondências $(\mathrm{V}, \mathrm{Q})$, desigualdades que ocorrem em um estado específico durante a simulação do comportamento do sistema. 


\section{APÊNDICE B - Modelo Desmatamento LS6}

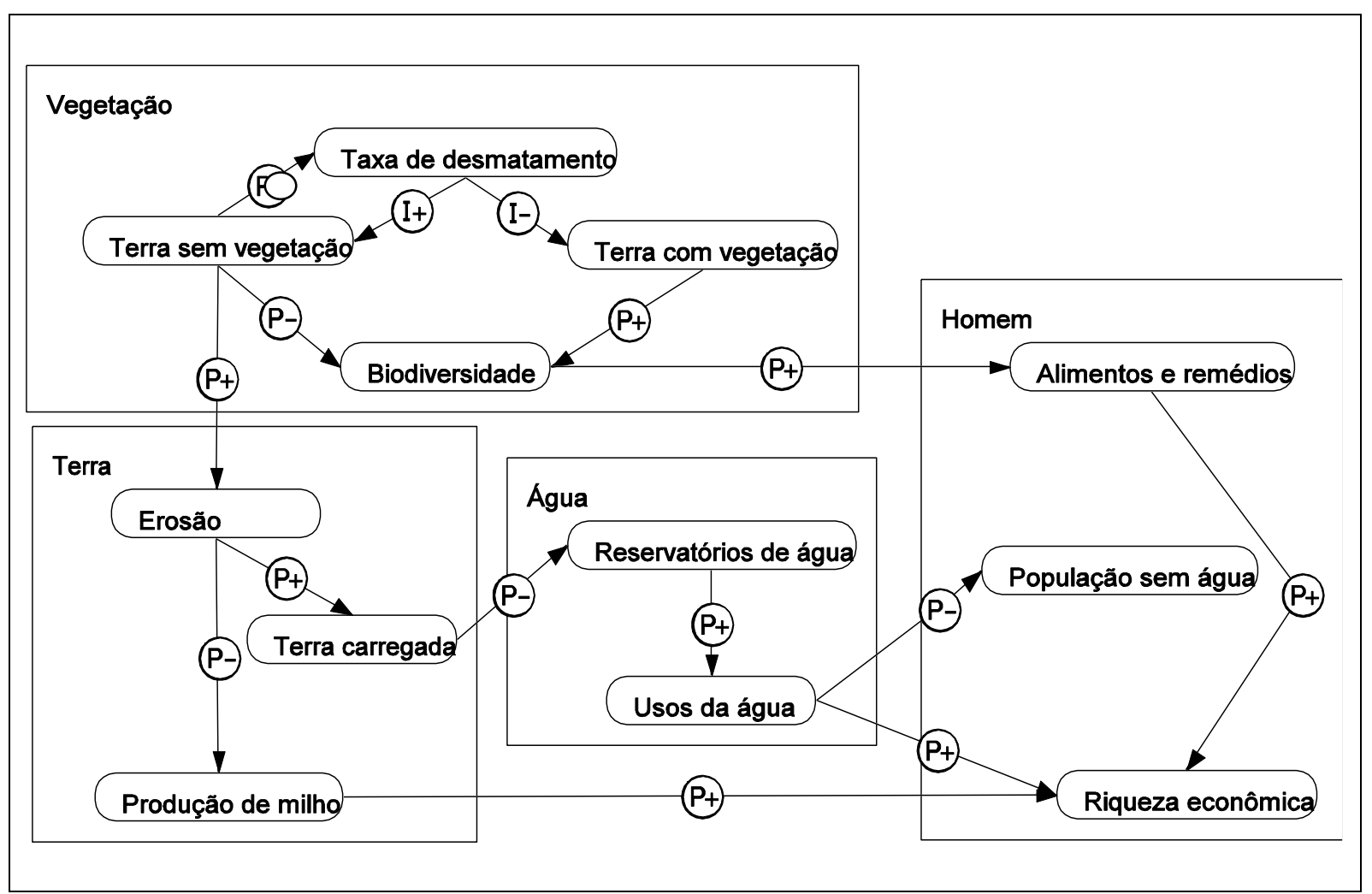

Modelo causal do desmatamento na versão LS6 


\section{APÊNDICE C - Modelo Desmatamento LS2}

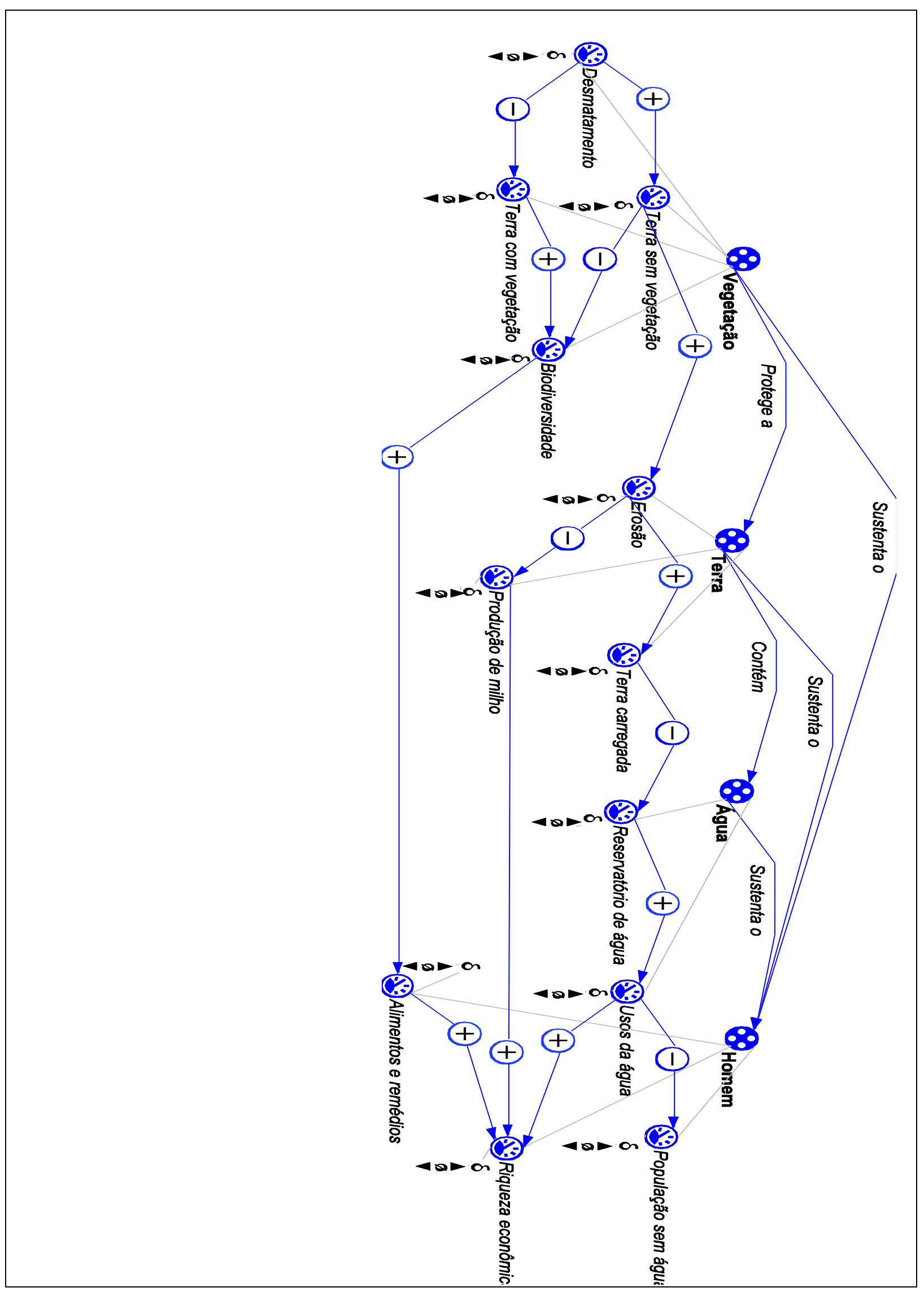


APÊNDICE D - Modelo Regeneração LS2

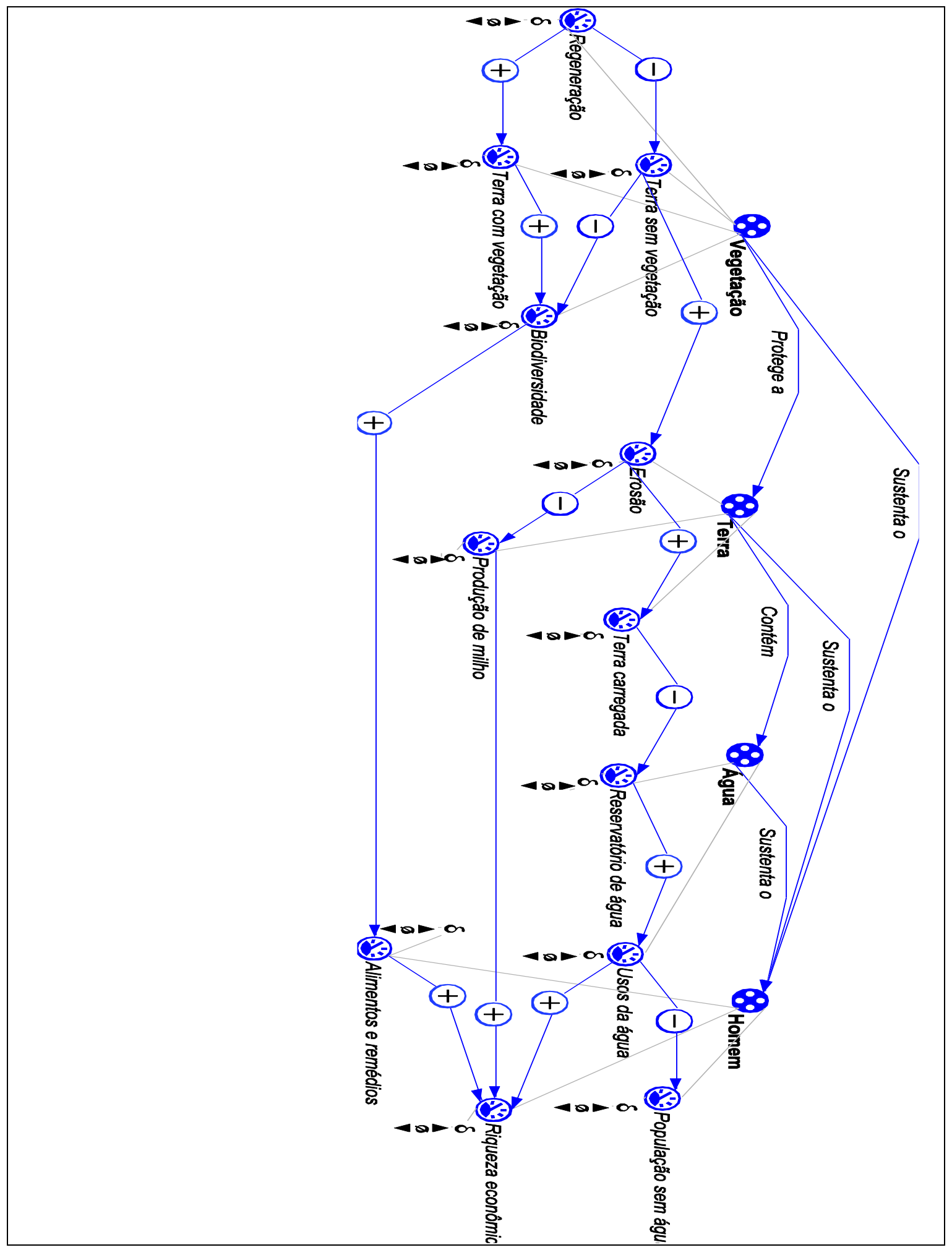


APÊNDICE E - Pré-teste

\section{UNIVERSIDADE DE BRASÍLIA}

NOME: Série:

\section{DESMATAMENTO - PRÉ-TESTE}

I - Responda Certo ( C ) ou Errado ( E ):

1 - ( ) SE o desmatamento aumenta, ENTÃO a terra sem vegetação aumenta.

2 - ( ) SE o desmatamento aumenta, ENTÃO a biodiversidade diminui.

3 - ( ) SE a biodiversidade diminui, ENTÃO a produção de alimentos e medicamentos diminui.

4 - ( ) SE a erosão diminui,

ENTÃO produção de milho diminui.

5 - ( ) SE a erosão aumenta, ENTÃO a terra carregada diminui.

6 - ( ) SE a produção de alimentos e medicamentos diminui, ENTÃO a riqueza aumenta.

7 - ( ) SE a produção de milho diminui, ENTÃO a riqueza diminui. 
II - Responda Certo ( C ) ou Errado ( E ):

8 - ( ) O reservatório de água diminuiu PORQUE a erosão aumentou.

9-( ) A população sem água aumentou PORQUE o reservatório de água diminuiu.

10 - ( ) A produção de milho aumentou PORQUE a erosão diminuiu.

11 - （） O reservatório de água diminuiu PORQUE a erosão aumentou.

12 - ( ) A terra com vegetação aumentou PORQUE o desmatamento diminuiu.

13 - ( ) A produção de alimentos aumentou PORQUE a biodiversidade diminuiu. 
III - Preencha as lacunas com AUMENTA ou DIMINUI:

14 - SE o desmatamento aumenta, ENTÃO a terra com vegetação

15 - SE a terra sem vegetação diminui, ENTÃO a biodiversidade

16 - SE a biodiversidade aumenta, ENTÃO a produção de alimentos e remédios

17 - SE a riquezaaumenta, ENTÃO a erosão

18 - SE aumenta a terra com vegetação, ENTÃO a produção de alimentos e remédios

19 - SE aumenta o desmatamento, ENTÃO a biodiversidade

20 - SE a terra sem vegetação aumenta, ENTÃO a erosão

21 - SE a erosão aumenta, ENTÃO a produção agrícola 
IV - Preencha as lacunas com AUMENTA ou DIMINUI:

22 - O reservatório de água aumenta PORQUE a terra carregada

23 - O uso da água aumenta PORQUE o reservatório de água

24 - A riquezaaumenta PORQUE o desmatamento

25 - A riquezadiminui PORQUE a biodiversidade

26 - A produção de alimentos e remédios diminui PORQUE a biodiversidade

27 - O reservatório de água diminui PORQUE a terra carregada

28 - A erosão diminui PORQUE a terra sem vegetação

29 - A produção de milho aumenta PORQUE a erosão 
V- Preencha as lacunas com AUMENTAouDIMINUI:

SE a erosão Aumenta,

ENTÃO:

30a terra carregada para longe

31 o buraco no chão

32 a produção de milho

33 o reservatório de água

34 o uso da água

35 a população sem água

36 a riqueza 
APÊNDICE F - Pós-teste

\section{UNIVERSIDADE DE BRASÍLIA}

DESMATAMENTO PÓS-TESTE

NOME:

Série:

I - Responda Certo ( C ) ou Errado ( E ).

1 - ( ) SE o desmatamento aumenta, ENTÃO a terra com vegetação aumenta.

2 - ( ) SE a terra com vegetação aumenta, ENTÃO a biodiversidade diminui.

3 - ( ) SE o reservatório de água diminui, ENTÃO os usos da água diminuem.

4 - ( ) SE a erosão aumenta, ENTÃO a população sem água aumenta.

5- ( ) SE o desmatamento diminui, ENTÃO a riqueza aumenta.

6 - ( ) SE a biodiversidade aumenta, ENTÃO a riqueza diminui.

7 - ( ) SE a erosão aumenta, ENTÃO a riqueza aumenta. 
II - Responda Certo ( C ) ou Errado ( E ).

8 - ( ) A biodiversidade diminuiu

PORQUEo desmatamento aumentou.

9-( ) A terra sem vegetação aumentou

PORQUEo desmatamento aumentou.

10 - ( ) A erosão aumentou

PORQUEa terra sem vegetação diminuiu.

11 - ( ) A terra carregada diminuiu

PORQUEa erosão aumentou.

12 - ( ) O reservatório de água aumentou

PORQUEa terra carregada aumentou.

13- ( ) O uso da água diminuiu

PORQUEo reservatório de água aumentou.

14- ( ) A terra com vegetação aumentou

PORQUE o desmatamento diminuiu. 
III - Preencha as lacunas com $\underline{\text { AUMENTA ou DIMINUI: }}$

15- SE a terra com vegetação aumenta, ENTÃO a biodiversidade

16- SE o desmatamento diminui ENTÃO a produção de alimentos e remédios

17- SE a erosão diminui ENTÃO a terra carregada

18- SE a terra carregada aumenta ENTÃO a produção de milho

19 - SE a terra sem vegetação aumenta ENTÃO a produção de milho

20 - SE a erosão diminui ENTÃO a produção de milho

21 - SE a terra carregada diminui ENTÃO o reservatório de água

22 - SE o reservatório de água diminui ENTÃO o uso da água 
IV - Preencha as lacunas com AUMENTOUouDIMINUIU:

23 - A produção de milho diminuiu PORQUEa terra carregada

24 - O uso da água diminuiu PORQUE o reservatório de água

25 - A terra carregada aumentou PORQUEa erosão

26 - O reservatório de água diminuiu PORQUEa terra carregada

27 - O reservatório de água diminuiu PORQUE a erosão

28 - A produção de alimentos e remédios aumentou PORQUE a biodiversidade

29 - O uso da água diminuiu PORQUE a terra carregada 
V - Preencha as lacunas com AUMENTA ou DIMINUI:

SE o Desmatamento aumenta, ENTÃO:

30- a terra com vegetação

31- a biodiversidade

32- a produção de alimentos e remédios

33- a erosão

34- o reservatório de água

35- a população sem água

36- a riqueza 


\section{APÊNDICE G - Atividade1}

\section{ATIVIDADE 1 \\ EXERCÍCIOS ÁRVORE+SOMBRA+TEMPERATURA}

\section{I- PREENCHA AS LACUNAS COM AUMENTA OU DIMINUI:}

1- SE a árvore cresce, ENTÃO a sombra da árvore

2- SE a sombra da árvore aumenta, ENTÃO a temperatura do solo

3- SE a árvore cresce, ENTÃO a temperatura do solo

4- A sombra aumenta PORQUE a árvore

5- A sombra aumenta PORQUE a árvore

6- A temperatura do solo diminui PORQUE a sombra da árvore

7- A temperatura do solo diminui PORQUE a árvore

8- A temperatura do solo aumenta PORQUE a sombra da árvore

\section{II- RESPONDA CERTO ( C ) OU ERRADO ( E ):}

9- ( ) SE a árvore cresce, ENTÃO sua sombra diminui.

10- ( ) SE a sombra da árvore aumenta, ENTÃO a temperatura do solo diminui.

11- ( ) SE a sombra da árvore diminui, ENTÃO a temperatura do solo aumenta.

12- ( ) A temperatura do solo diminui, PORQUE a sombra da árvore diminui.

13- ( ) A sombra da árvore aumenta PORQUE a árvore cresce. 


\section{Taxa de crescimento.}

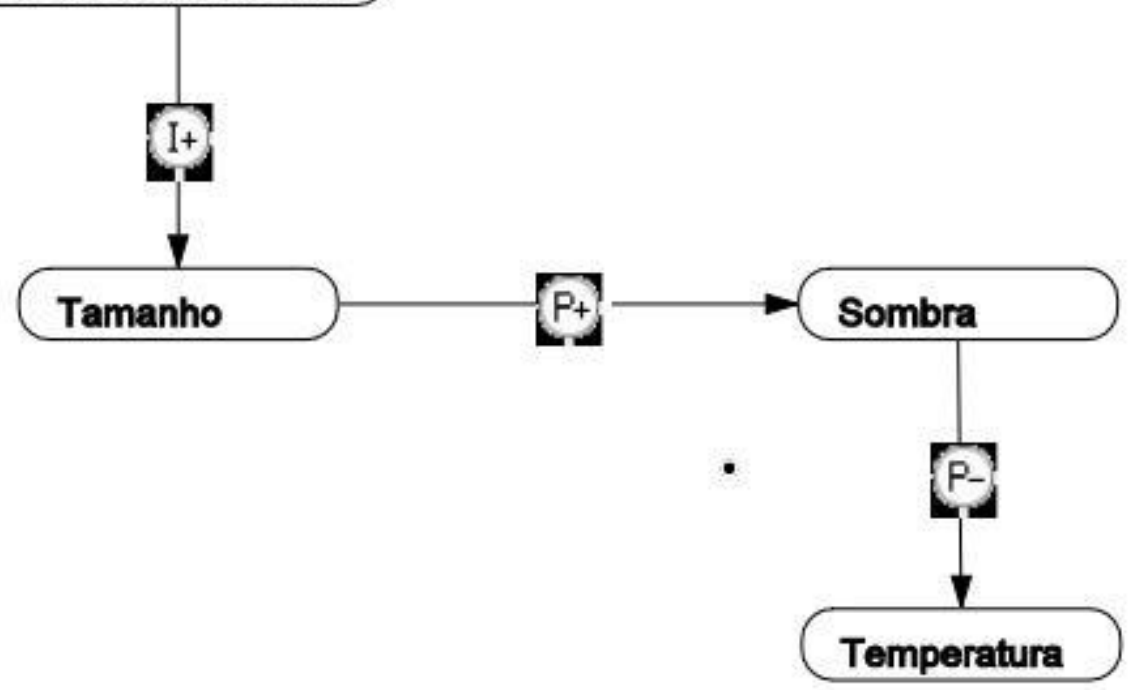

Seguindo o modelo apresentado acima, responda o que se pede no próximo exercício:

III- Descreva o que está acontecendo nas ilustrações abaixo.

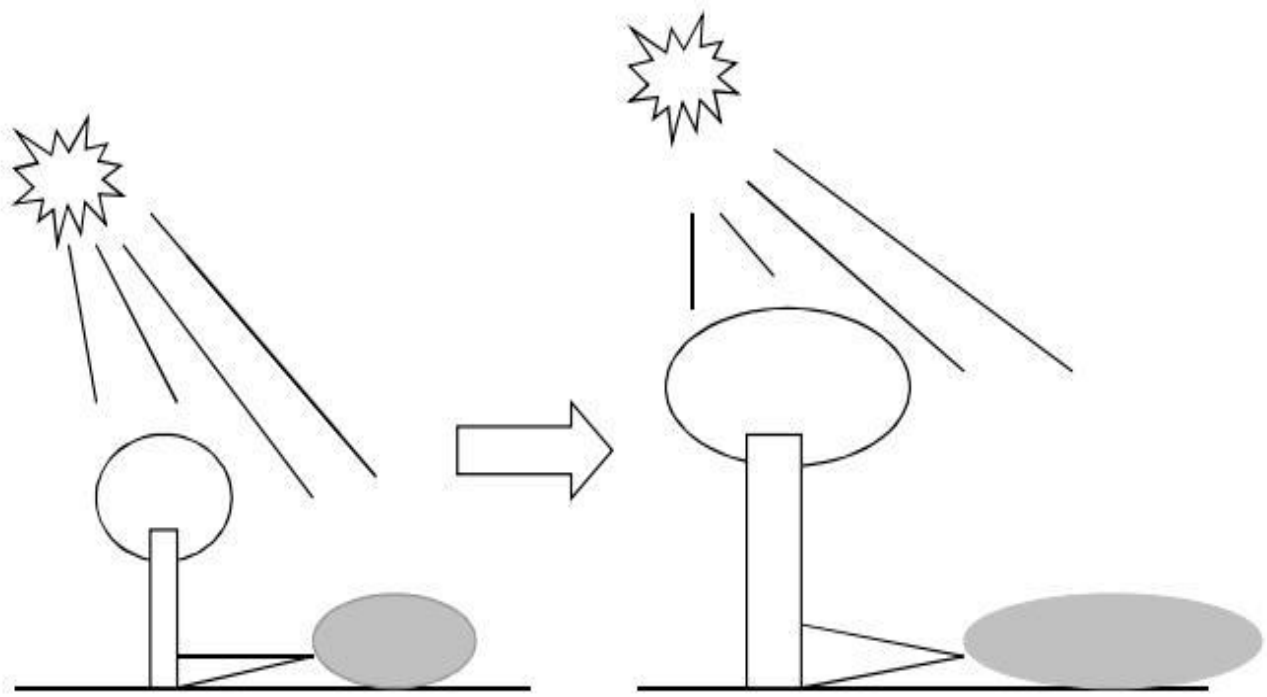




\section{APÊNDICE H - Atividade2}

Nome:

Turma:

Sobre os modelos abaixo, complete-as lacunas com AUMENTA, DIMINUIouESTABILIZA:

Modelo1

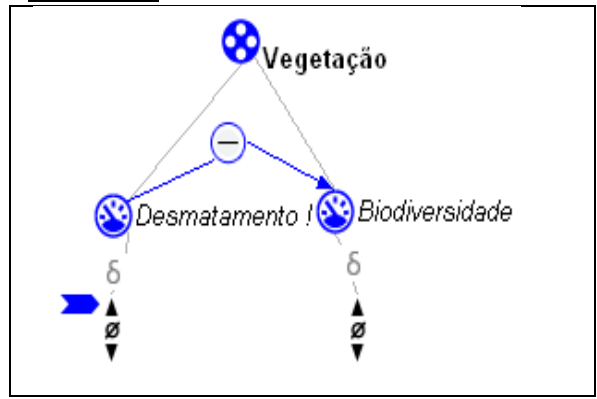

Modelo2

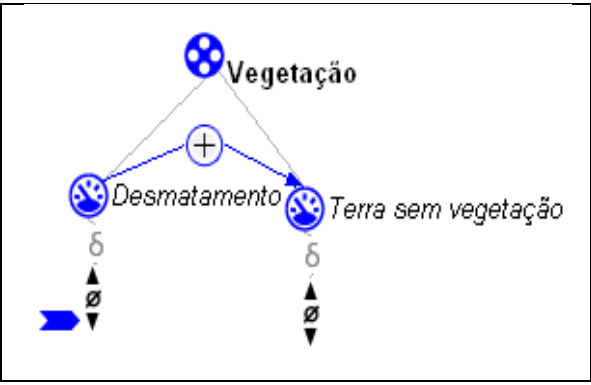

Modelo3

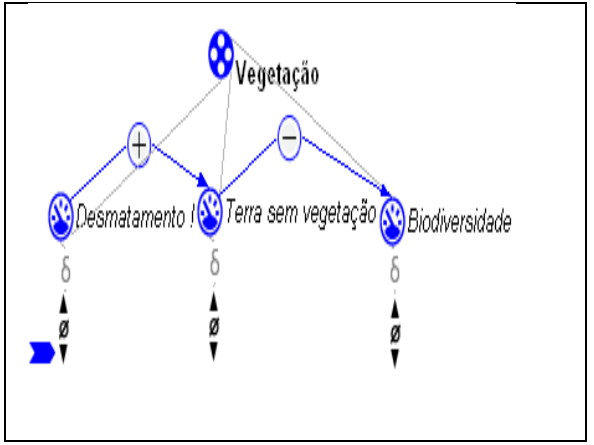

Modelo4

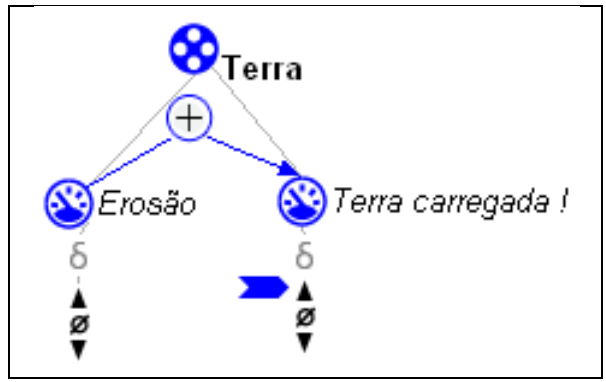

Se Desmatamento

Então Biodiversidade...

Se DesmatamentoDiminui,

Então Terra sem vegetação...

Se Desmatamento $\underline{\text { AUMENTA, }}$

Então Terra sem vegetação...

Se Terra sem vegetação...

Então Biodiversidade...

Se Erosão...

Então Terra carregada AUMENTA. 
$\underline{\text { Modelo5 }}$

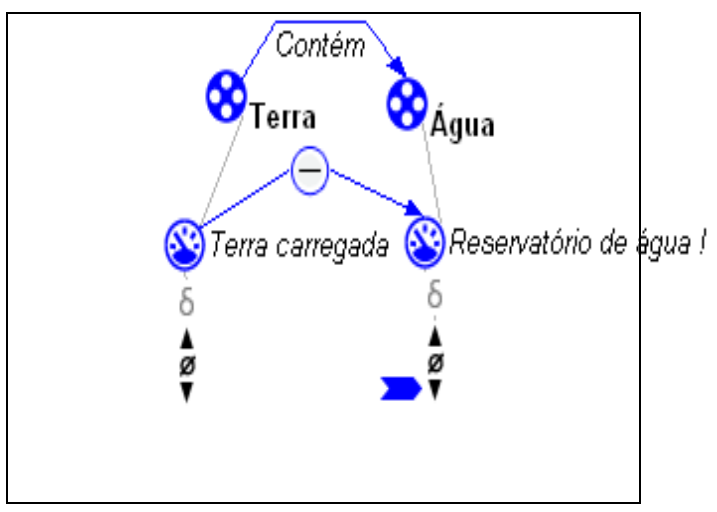

Modelo6

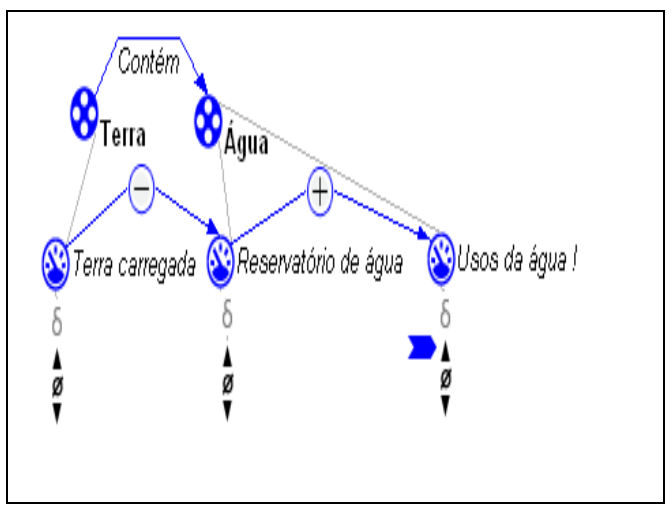

SeTerra Carregada...

EntãoReservatóriosde águaDiminui.
SeTerra carregada...

EntãoReservatórios de água ...

SeReservatóriosdeágua

EntãoUsos da águaAUMENTA.

II - Complete os modelos abaixo com os sinais de (+) ou (-):

Modelo7

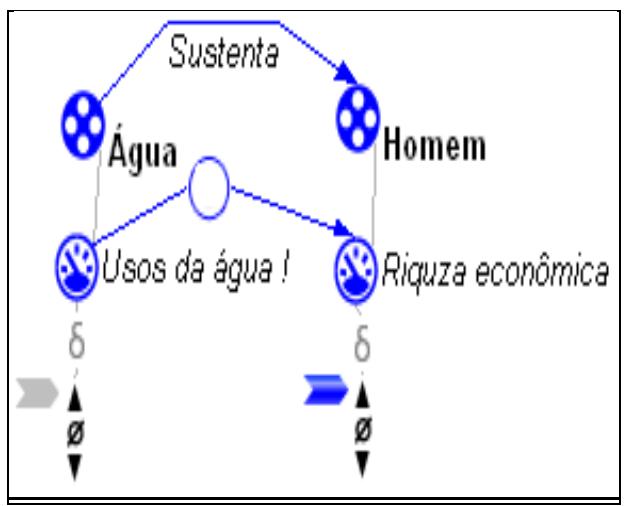

Modelo8

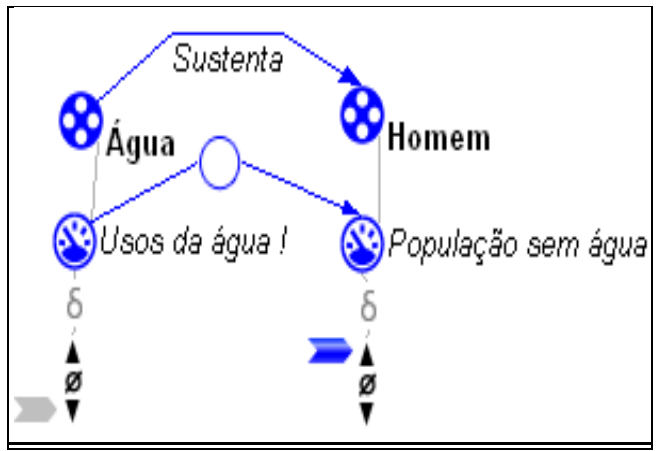

A relação entre as quantidades Usos da água e Riqueza econômica é identificada por uma seta

com uma influência

A relação entre as quantidades Usos da água e População sem água é identificada por uma seta

com uma influência 


\section{Modelo9}

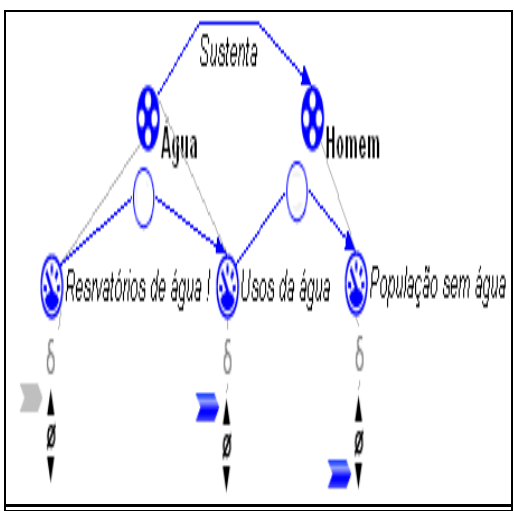

A relação entre as quantidades Reservatórios de água e Usos da água é identificada por uma seta com uma influência

A relação entre as quantidades Reservatórios de água e Usos da água é identificada por uma seta com uma influência

\section{Modelo10}

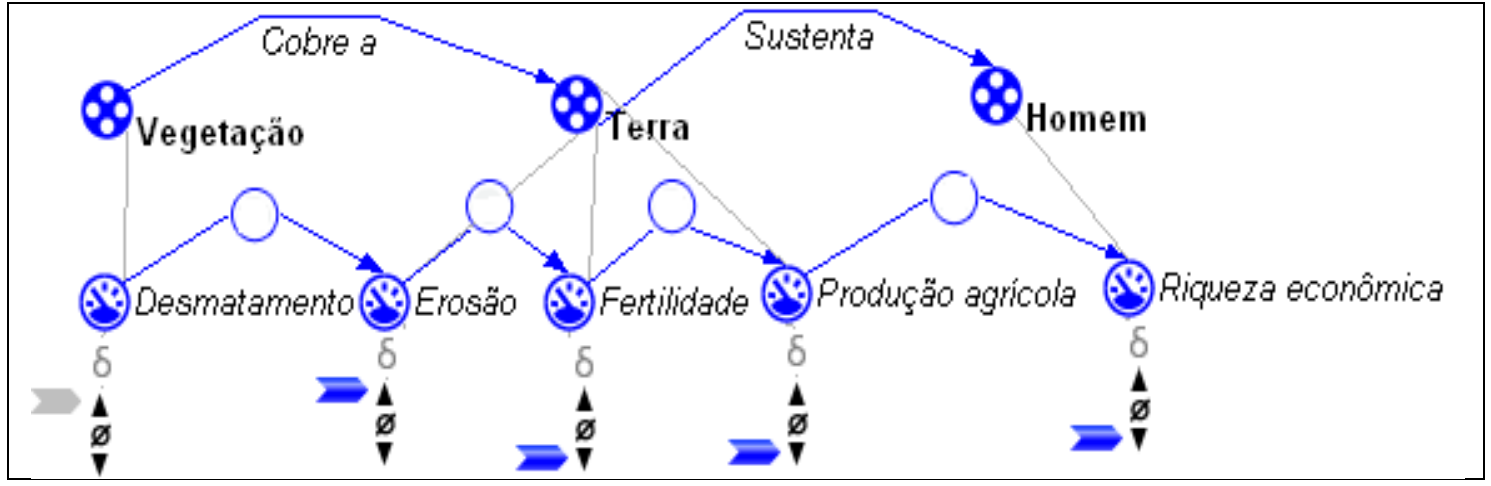

A relação entre as quantidades Desmatamento e Erosão é identificada por uma seta

com uma influência

A relação entre as quantidades Erosão e Fertilidade é identificada por uma seta

com uma influência

A relação entre as quantidades Fertilidade e Produção agrícola é identificada por uma seta com uma influência

A relação entre as quantidades Produção agrícola e Riqueza econômica é identificada por uma seta com uma influência 


\section{APÊNDICE I - $\underline{\text { Atividade3 }}$}

Nome:

Turma:

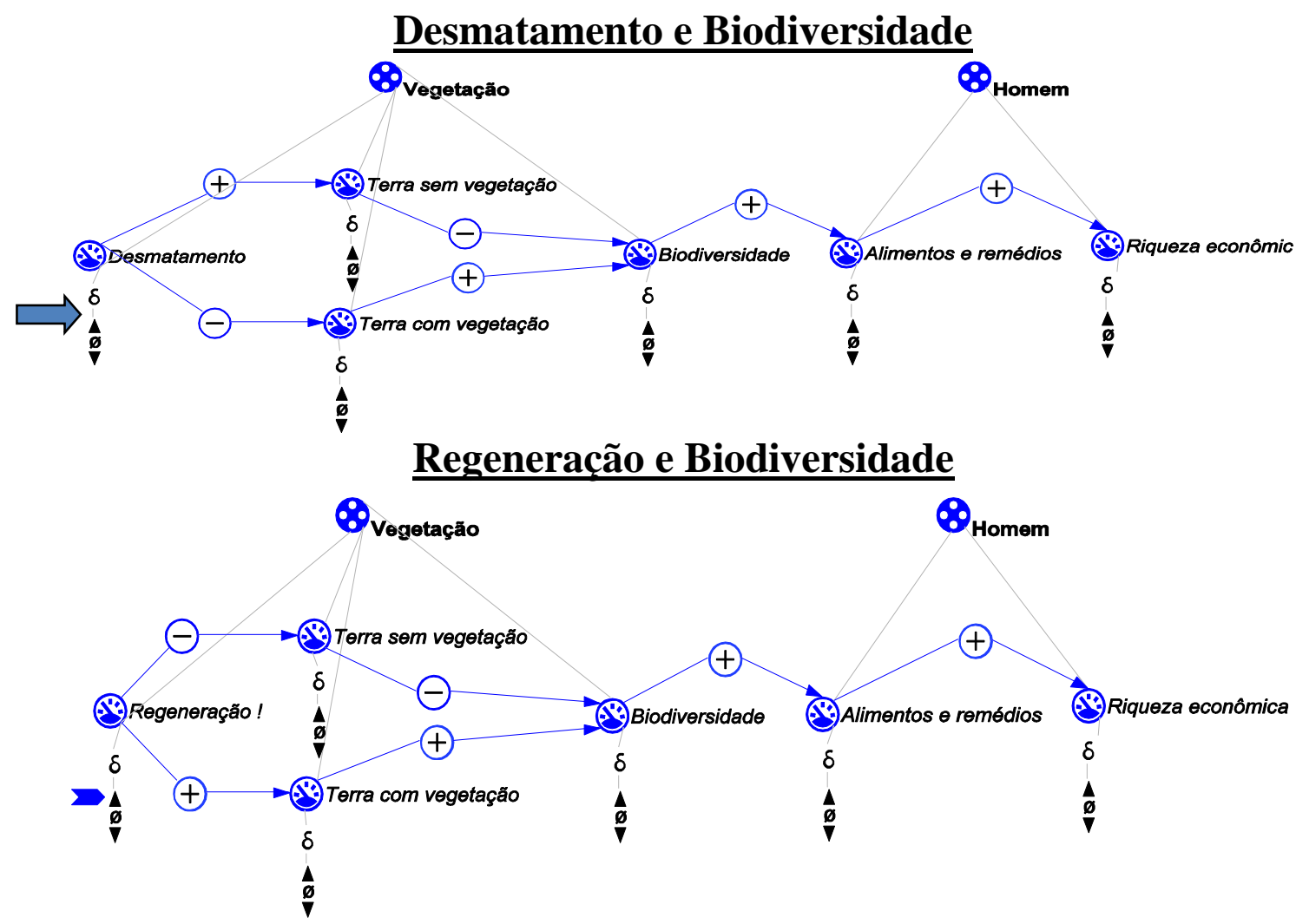

Desmatamento, Erosão, Produção agrícola e Riqueza econômica

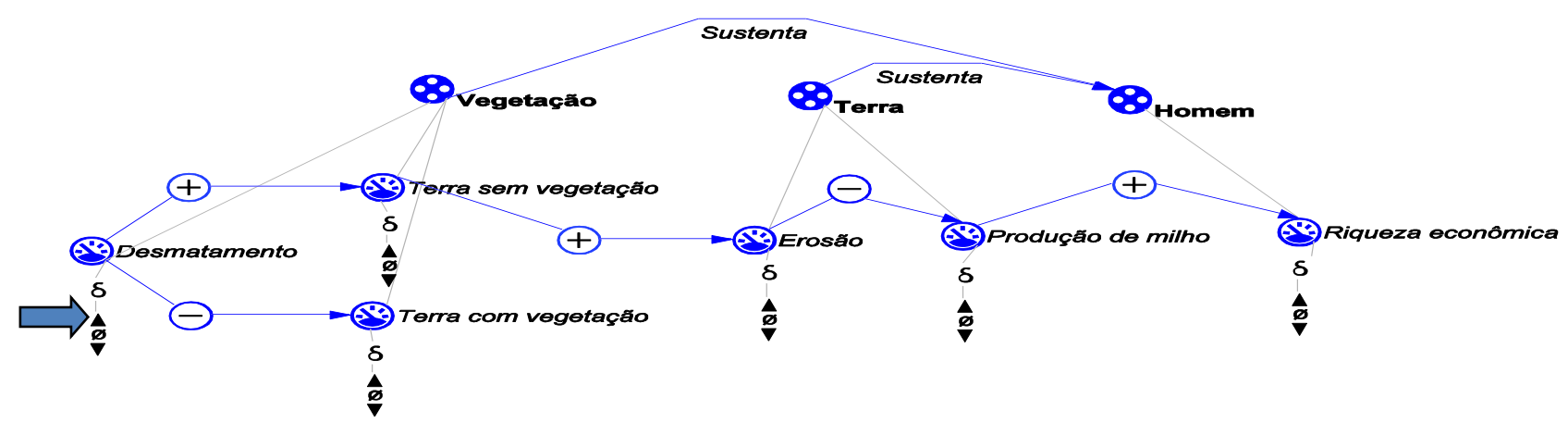

Regeneracãa, Erosão, Produção agrícola e Riqueza econômica

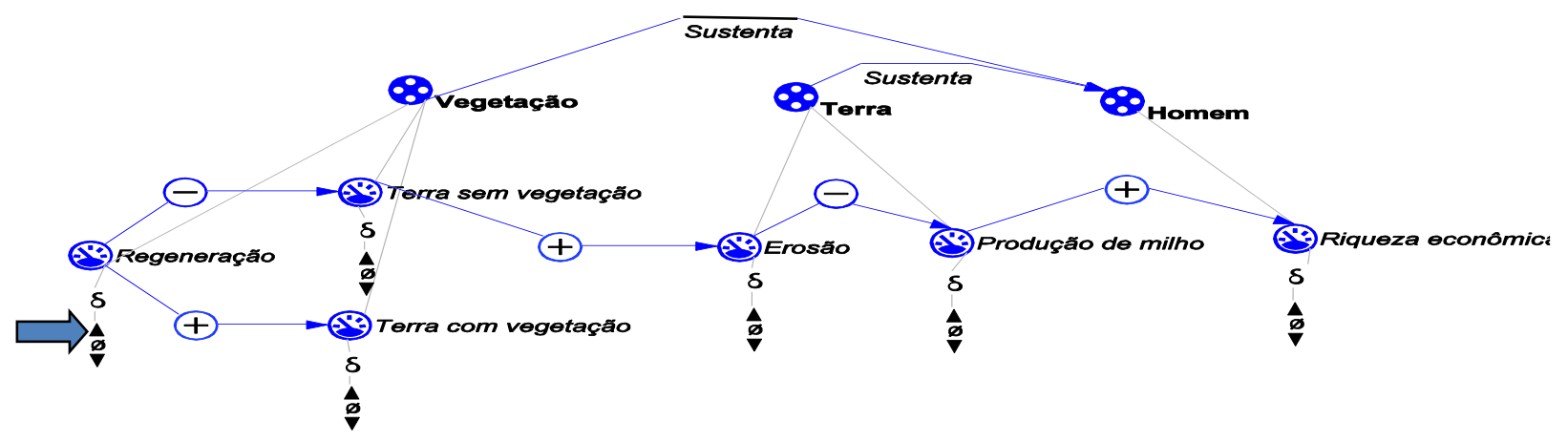


Aluno:

Turma:

Complete o modelo causal marcando as setas nas derivadas:

1)

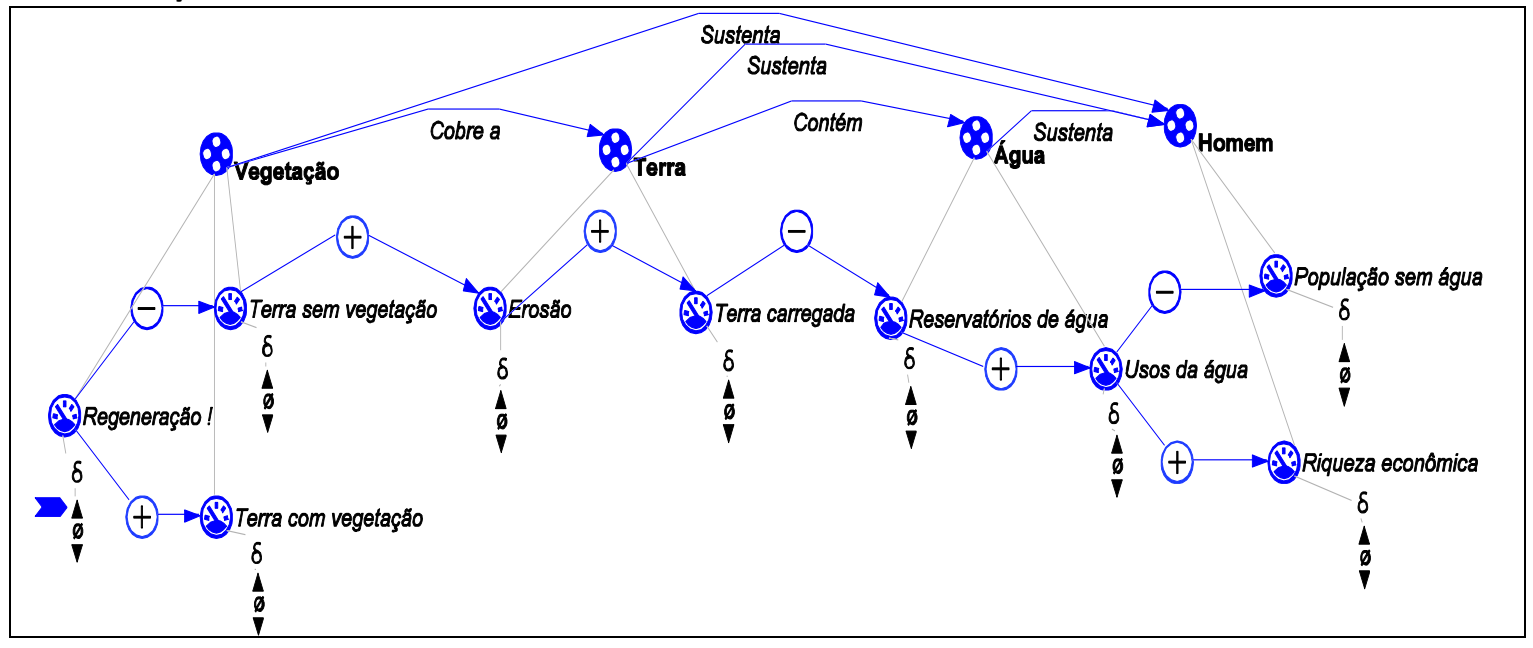

2)

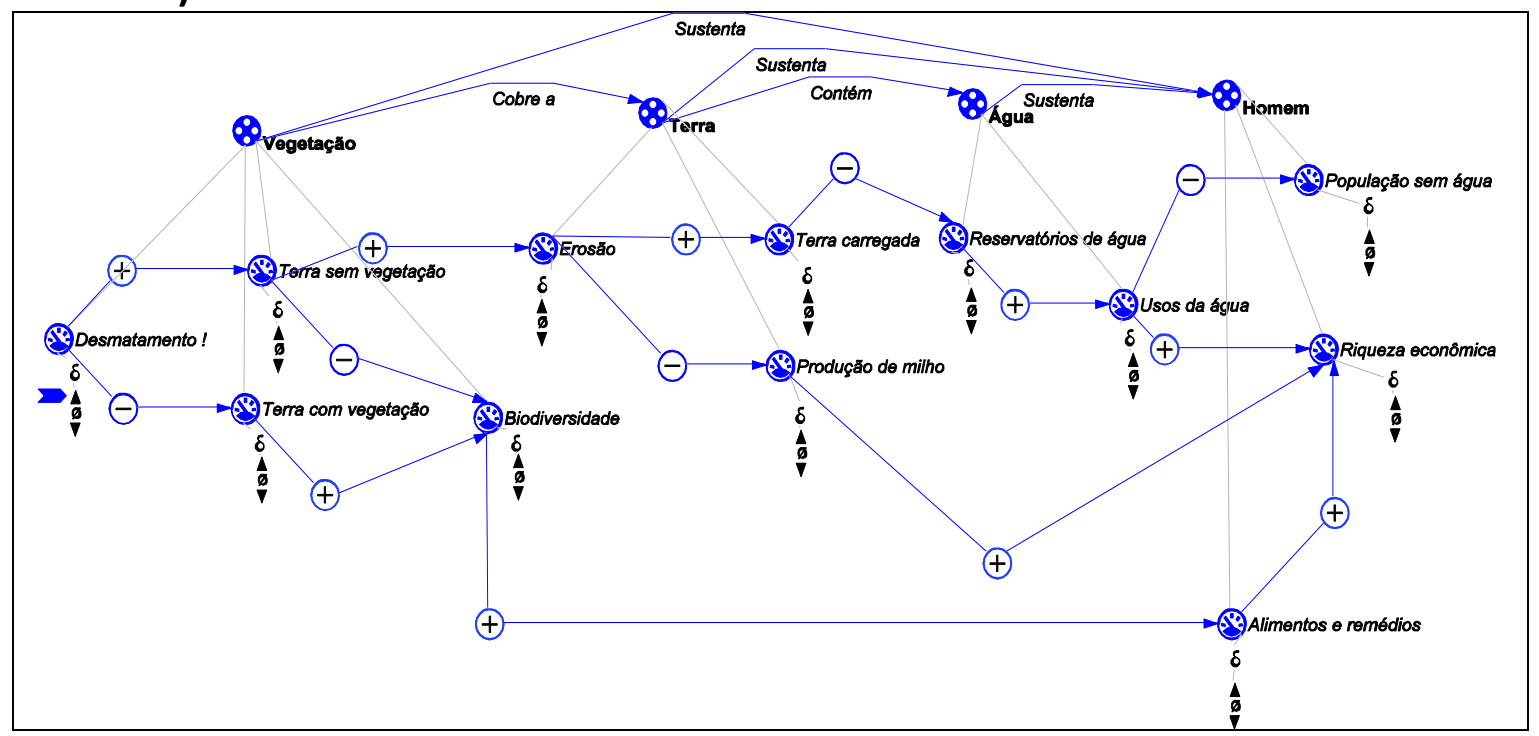

3)

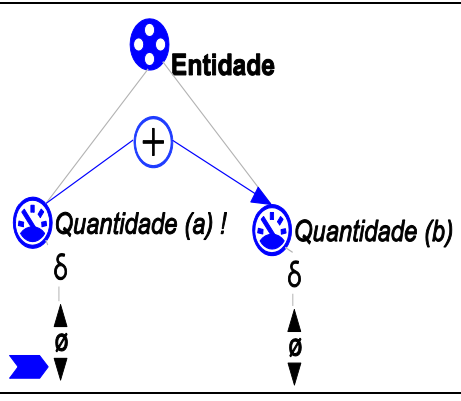


APÊNDICE K - Termo de consentimento

\section{Termo de consentimento}

Eu,

idade portador do CPF

autorizo o usodas informações obtidas por meio de imagens, áudios, questionários, entrevistas, testes e outros, durante sua participação no curso que realizamos, sejam utilizados, sem que você seja identificado pessoalmente, na pesquisa de mestrado desenvolvida por Fabrício Bechepeche Alves, bem como em publicações científicas, livros, artigos e quaisquer outros instrumentos de pesquisa e divulgação científica decorrentes deste trabalho.

Ass.:

Data:

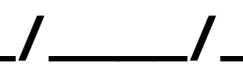

Agradeço desde já sua colaboração e a imensa ajuda em participar desta pesquisa. 


\section{APÊNDICE L - Avaliação do curso- alunos surdos}

Universidade de Brasília

Programa de Pós-Graduação em Ensino de Ciências

Pesquisador: Fabrício Bechepeche Alves

\section{Avaliação do curso baseado em modelos qualitativos}

\section{Identificação do aluno:}

Nome (opcional):

Idade: Série

\section{Legenda:}

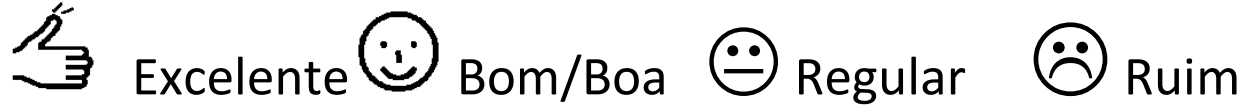

\begin{tabular}{|c|c|c|c|c|}
\hline $\begin{array}{l}\text { Avalie os itens a seguir marcando a resposta com um X no } \\
\text { quadro apropriado. }\end{array}$ & 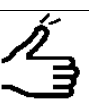 & & $\stackrel{\circ}{\circ}$ & \\
\hline 1. Qual a sua opinião sobre a apresentação geral do curso? & 0 & 0 & 0 & 0 \\
\hline $\begin{array}{l}\text { 2. O que você achou do conteúdo das atividades propostas } \\
\text { no curso? }\end{array}$ & 0 & 0 & 0 & 0 \\
\hline $\begin{array}{l}\text { 3. Qual a sua opinião sobre o software () utilizado para } \\
\text { construir os modelos qualitativos? }\end{array}$ & 0 & 0 & 0 & 0 \\
\hline $\begin{array}{c}\text { 4. Qual a sua opinião sobre a linguagem (entidades, } \\
\text { influências, proporcionalidades) utilizada para construir os } \\
\text { modelos qualitativos? }\end{array}$ & 0 & 0 & 0 & 0 \\
\hline $\begin{array}{l}\text { 5. Qual a sua opinião sobre a clareza dos conceitos } \\
\text { expressos nos modelos qualitativos? }\end{array}$ & 0 & 0 & 0 & 0 \\
\hline $\begin{array}{l}\text { 6. O que você achou do vocabulário usado nos modelos } \\
\text { qualitativos para descrever os assuntos abordados? }\end{array}$ & 0 & 0 & 0 & 0 \\
\hline $\begin{array}{l}\text { 7. Qual a sua opinião sobre a clareza na apresentação das } \\
\text { relações de causa - efeito nos modelos qualitativos? }\end{array}$ & 0 & 0 & 0 & 0 \\
\hline $\begin{array}{c}\text { 8. Como você classifica o seu entendimento sobre os } \\
\text { problemas apresentados, depois de estudar os modelos } \\
\text { qualitativos? }\end{array}$ & 0 & 0 & 0 & 0 \\
\hline $\begin{array}{l}\text { 9. Como você avalia a contribuição dos modelos } \\
\text { qualitativos para a sua aprendizagem? }\end{array}$ & 0 & 0 & 0 & 0 \\
\hline $\begin{array}{l}\text { 10. O que você acha da idéia de usar modelos qualitativos } \\
\text { na sala de aula? }\end{array}$ & 0 & 0 & 0 & 0 \\
\hline
\end{tabular}

Muito obrigado pela sua colaboração!! 
APÊNDICE M -Roteiro da entrevista e ficha de consentimento

$\underline{\text { Roteiro para a Entrevista e ficha de consentimento }}$

EXPERIÊNCIA COM MODELAGEM

(1) Você compreendeu claramente o objetivo das tarefas de modelagem? surdos?

(2) Na sua opinião, a modelagem foi uma tarefa motivadora para alunos

(3) O que você achou da modelagem conceitual? Modelos conceituais e simulações poderiam efetivamente ser ferramenta de apoio à aprendizagem de alunos surdos?

\section{MODELOS E SIMULAÇÕES}

(4) Em sua opinião, a diferença entre os elementos da modelagem entidades e quantidades ficaou clara para os alunos?

(5) Em sua opinião, os alunos surdos compreenderam a forma como os espaços quantitativos descrevem as variáveis qualitativamente?

(6) Qual foi sua impressão ao ver os alunos surdos trabalharem com simulações?

(7) Rodar simulações com os modelos ajuda a desenvolver em alunos surdos a compreensão do comportamento dos sistemas (isto é, da dinâmica dos sistemas)?

\section{USOS NA EDUCAÇÃO}

(8) Qual é a sua opinião geral sobre o curso e as atividades de aprendizagem que tivemos juntos com os alunos surdos?

(9) Por favor, comente o papel que modelos e atividades de modelagem poderiam ter na educação de alunos surdos em relação aos seguintes aspectos:

(a) desenvolvimento da linguagem sobre conceitos científicos

(b) desenvolvimento de novos conceitos

(c) esclarecimentos de conceitos já estudados

(d) capacidade de raciocinar

(e) desenvolvimento da capacidade de argumentar

(f) capacidade de julgar decisões, atividades, propostas

(10) Por favor, comente o papel que modelos e atividades de modelagem poderiam ter nas seguintes atividades pedagógicas:

(a) atividades interdisciplinares

(b) desenvolvimento de competências e habilidades

(c) atividades baseadas em projetos

(d) atividades que os alunos desenvolvem em laboratórios escolares 
(11) Quais são as principais dificuldades que você apontaria para levar a modelagem para a sala de aula? $\mathrm{E}$ as possíveis soluções para essas dificuldades?

(12) Em que disciplinas do currículo da educação básica você recomendaria o uso da modelagem qualitativa e de modelos de simulação?

(13) Como você avalia a experiência de se trabalhar com o software ? Quais foram as vantagens e as dificuldades que você identificou para que os professores $o$ utilizem com seus alunos?

(14) Como você avalia a importância de construir modelos específicos em diferentes níveis de complexidade para os alunos surdos?

(15) Que nível de complexidade do (LS2 ou LS6) você considera que mais contribui para o aluno surdo compreender conceitos representados em modelos qualitativos?

(16) $O$ que você acha que a modelagem oferece a você, como professor, se tiver que ensinar aos surdos sobre os efeitos do Desmatamento e da Regeneração da vegetação?

\section{QUESTÕES ABERTAS}

(17) De que você gostou?

(18) De que você não gostou?

(19) Alguma idéia para melhorar o software?

(20) Você tem algum outro comentário?

Eu

idade

autorizo que as informações contidas nessa ficha, bem como todos os dados colhidos durante o curso ofertado (imagens, áudios, questionários, entrevistas e outros), sejam utilizados na pesquisa de mestrado desenvolvida por Fabrício Bechepeche Alves e autorizo também o uso destes em publicações científicas, livros, artigos e quaisquer outros instrumentos de pesquisa e divulgação científica.

Ass.:

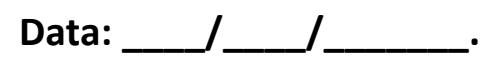

Agradeço desde já a colaboração e a imensa ajuda em participar desta pesquisa. 
APÊNDICE N- Slides utilizados para trabalhar Silogismos e questões "Se... Então..."
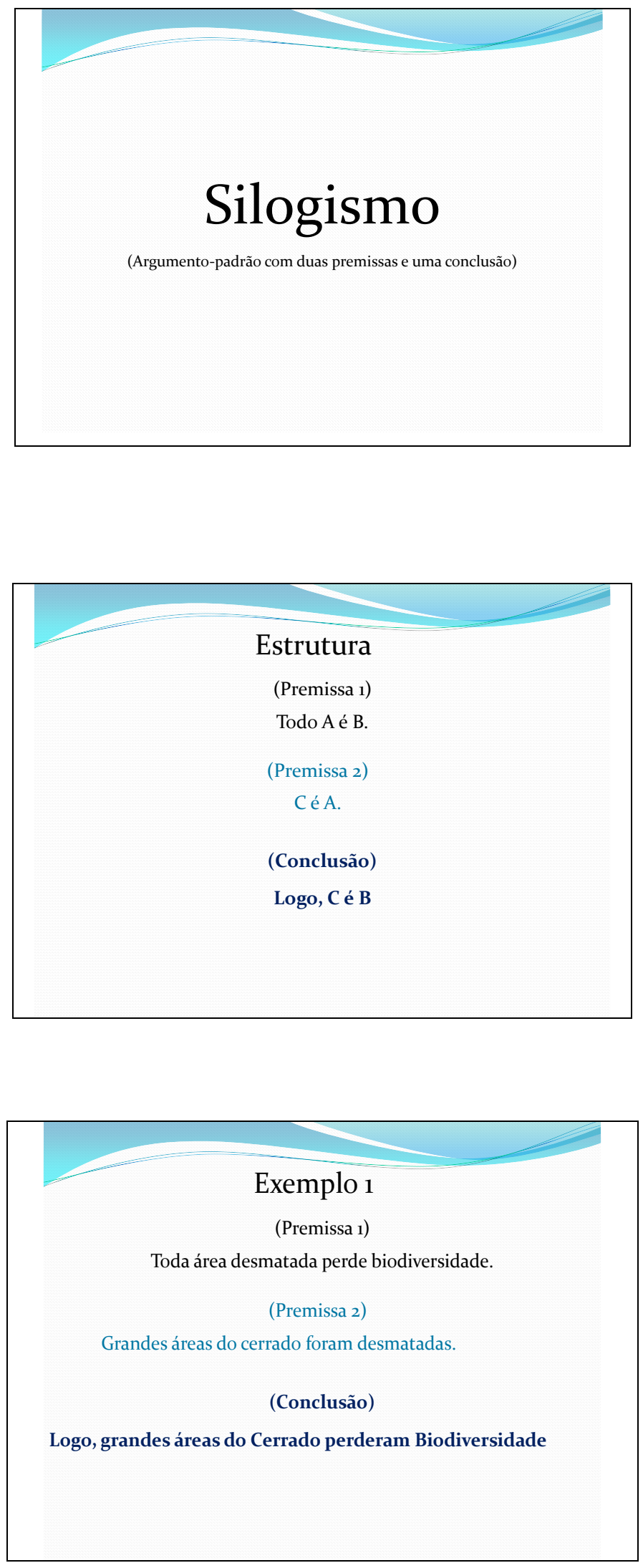


\section{Exemplo 2}

(Premissa 1)

Toda área desmatada sofre processo de erosão do solo.

$$
\text { (Premissa 2) }
$$

Grandes áreas do cerrado foram desmatadas.

(Conclusão)

Logo, grandes áreas do Cerrado tem problema de erosão.

\section{Exemplo 3}

(Premissa 1)

Toda área com problema de erosão sofre perda de fertilidade do solo

(Premissa 2)

Grandes áreas do cerrado tem problemas de erosão.

(Conclusão)

Logo, grandes áreas do Cerrado sofrem perda de fertilidade do solo.

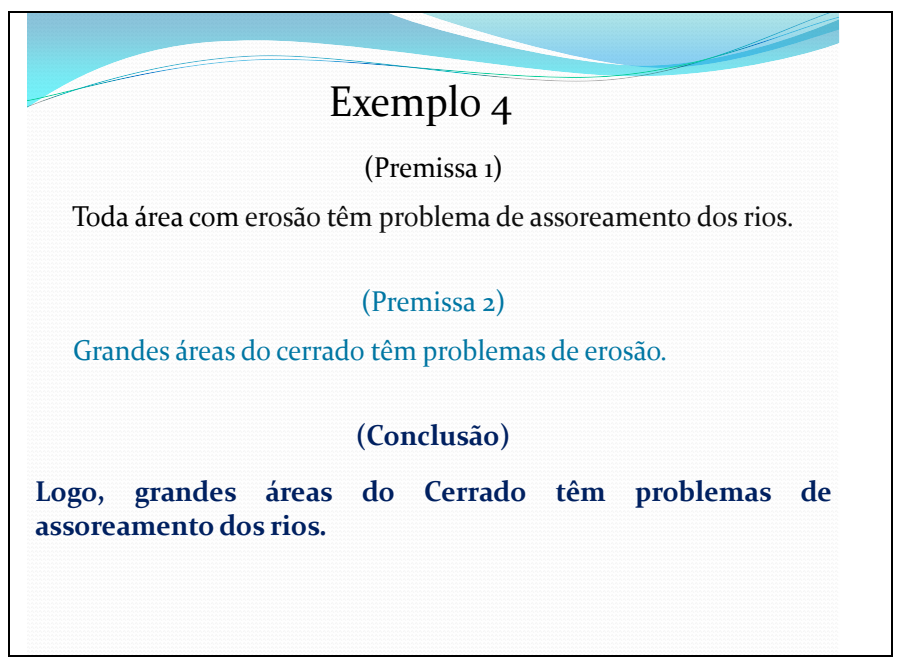




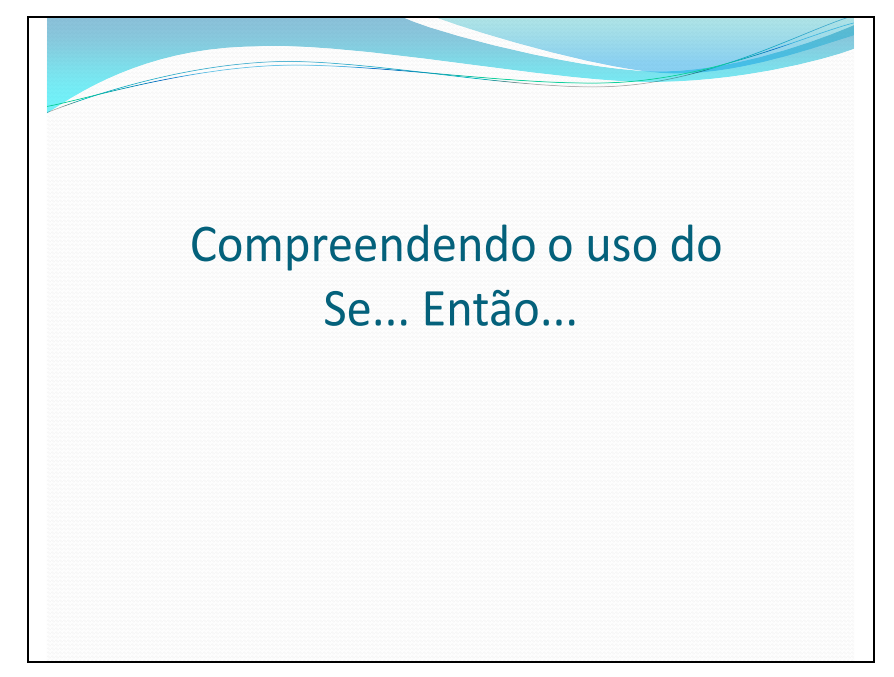

Se... Então...

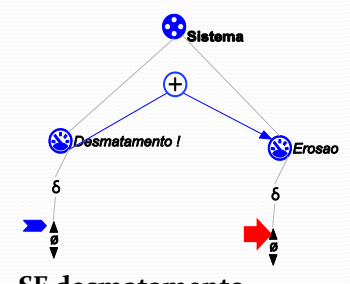

SE desmatamento aumenta...

ENTÃO erosão aumenta

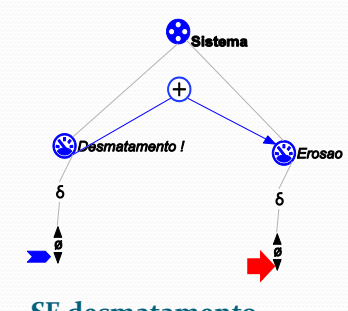

SE desmatamento diminui...

ENTÃO erosão diminui

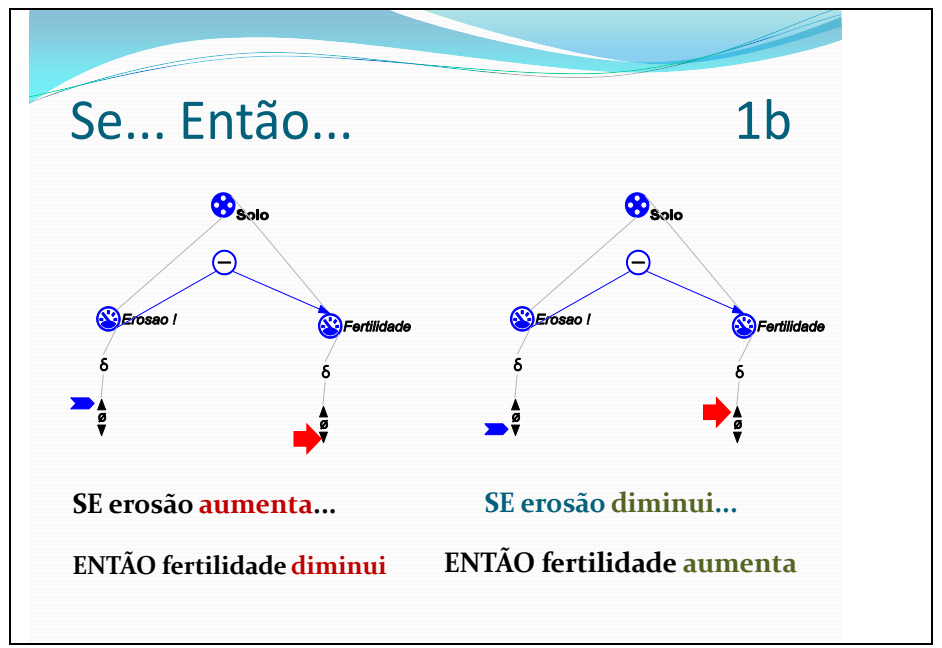



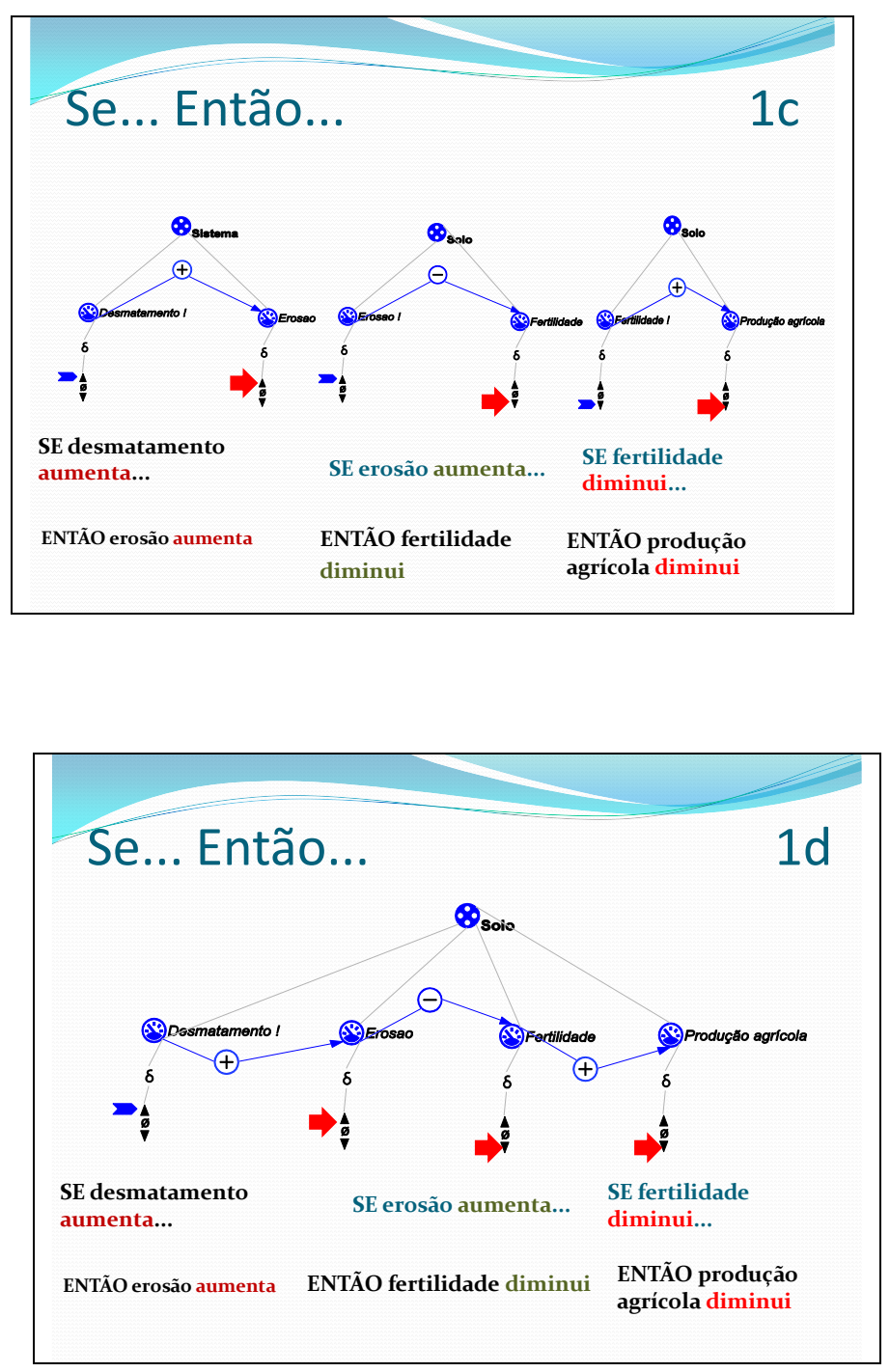
APÊNDICE O- PROPOSTA DE CURSO

PROPOSTA DE CURSO 


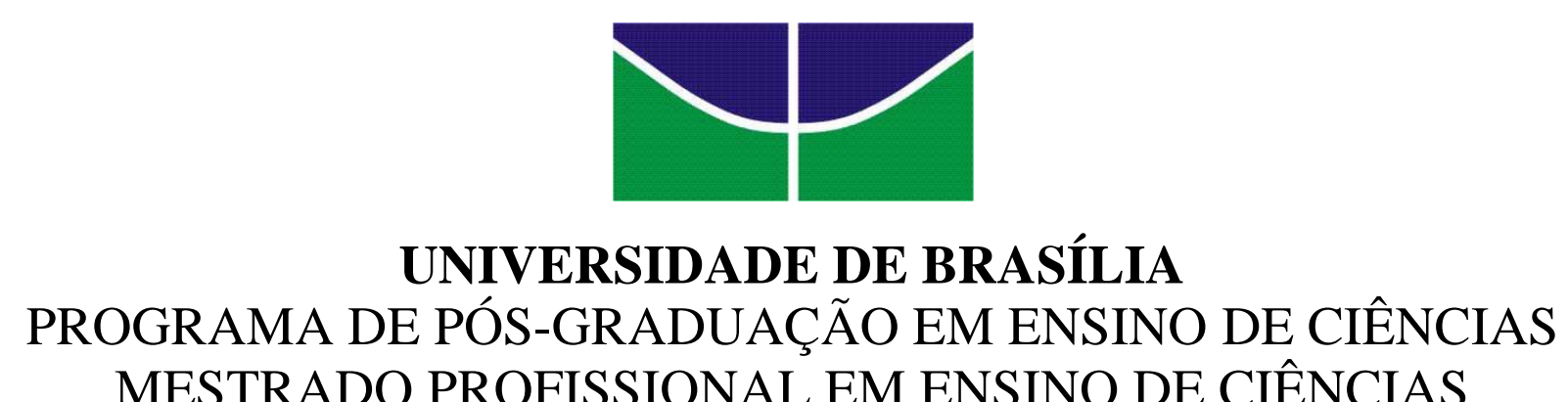

MESTRADO PROFISSIONAL EM ENSINO DE CIÊNCIAS

\section{USODE MODELOS QUALITATIVOS NA EDUCAÇÃO CIENTÍFICA PARA ALUNOS SURDOS}

FABRÍCIO BECHEPECHE ALVES

$\mathrm{e}$

PROF. DR. PAULO SÉRGIO BRETAS DE ALMEIDA SALLES

(Orientador)

Brasília, DF

Julho

2015 
Proposta de curso com metodologia baseada em modelos qualitativos no desenvolvimento do raciocínio hipotético dedutivo e na educação cientifica de alunos surdos, trabalhando de forma interdisciplinar com o Português escrito como segunda língua dentro de um contexto bilíngue com LIBRAS.

PROPOSTA DE CURSO

USO DE MODELOS QUALITATIVOS NA EDUCAÇÃO CIENTÍFICA PARA ALUNOS SURDOS 


\section{APRESENTAÇÃO}

A proposta de curso aqui apresentada foi baseada em um Manual Instrucional (SALLES et al., 2013)produzido para o Projeto "Laboratório de Pedagogia Visual (LAPEVI), para a Educação Bilíngue de Surdos - LIBRAS / Português",destinando-se à professores de Ciências e Biologia, que trabalham com alunos surdos do Ensino Médio.

Agradeço ao professor Doutor em Ecologia Paulo Sérgio Bretas de Almeida Salles, autor do Manual Instrucional junto com a coordenadorado Projeto LAPEVI, Prof. Dra. Heloisa Moreira Lima Salles, que colaborou com os aspectos linguísticos do trabalhoe as professoras Mestres em Ensino de Ciências e especialistas em LIBRAS, GiseleMorissonFeltrini e Mônica Maria Pereira Resende, coautoras dessa obra, e aos demais colaboradores no desenvolvimento e avaliação desse material de apoio para essa pesquisa.

A partir desse material, foi explorado o tema "Desmatamento" de maneira a trabalhar conceitos fundamentais para compreensão da dinâmica de sistemas, tais como:noção de processos, relações de causa e efeito que explicam fenômenos físicos e biológicos e a importância da preservação do ambiente para a sociedade.

Para isso, foram utilizados modelos de simulação, como metodologia que ilustra o modelo do desmatamento, que será apresentado e desenvolvido passo a passo, com explicações para cada etapa. Isso auxilia ao professor preparar e desenvolver seus próprios modelos e materiais didáticos para que os alunos possam compreender e explorar na totalidade o potencial do uso de modelos de simulação dentro de uma grande diversidade de tópicos curriculares que podem ser trabalhados junto a eles.

Também é possível que os próprios alunos passem a construir modelos de simulação, tendência que começa a ocorrer em diversos países da Europa, da América do Norte e que começa a ser explorada também aqui no Brasil. 


\section{SUMÁRIO}

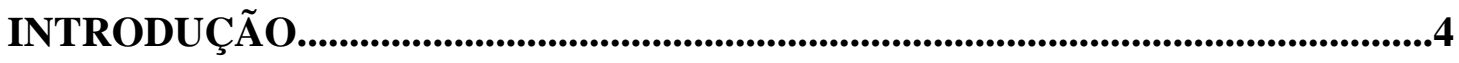

CAPÍTULO 1 - DESCRIÇÃO DO CURSO..............................................................6

CAPÍTULO 2 - APRESENTAÇÃO DOS MODELOS QUALITATIVOS E DO

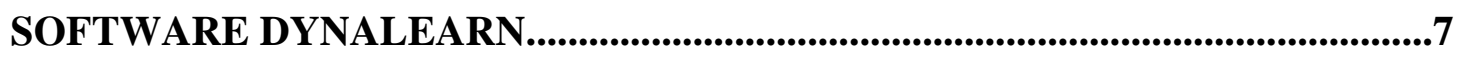

CAPÍTULO 3 - O MODELO 'DESMATAMENTO' ................................................13

CÁPITULO 4 - MODELOS EM UM FORMATO VISUAL....................................22

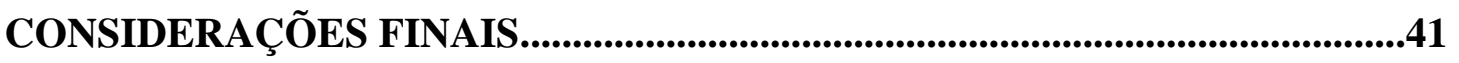

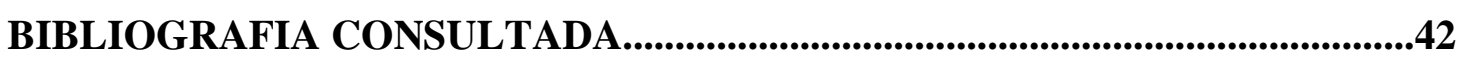

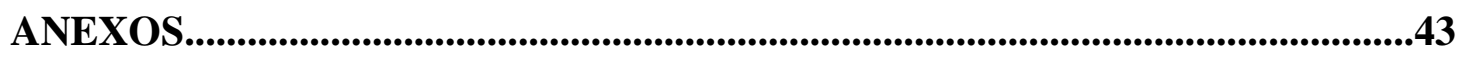




\section{INTRODUÇÃO}

O aluno surdo enfrenta várias dificuldades para compreender os diversos conteúdos que são abordados junto a eles, isso se deve principalmente à linguagem e à metodologia adotadas para se trabalhar com esse público, que necessita de uma abordagem adaptada à sua necessidade, permitindo a participação ativa do aluno durante as aulas e com isso, a sua inclusão. As principais metodologias que demonstram resultados positivos no trabalho com alunos surdos são aquelas que utilizam de recursos visuais e que proporcionam uma interatividade do aluno com o que está sendo estudado.

A utilização de modelos qualitativos na educação científica de estudantes surdos foi estudada em vários trabalhos que antecedem a esse, tais como: Salles et al. (2004); Salles et al. (2005); Feltrini (2009); Resende (2010). Esses trabalhos demonstraram que os modelos qualitativos apresentam características singulares que justificam seu uso na educação de surdos, que são:

- Utilizam uma linguagem coloquial para explicar conceitos científicos, facilitando a transposição LIBRAS/ Português escrito;

- Demonstram claramente relações de causa e efeito, oferecendo suporte para o desenvolvimento de raciocínio lógico e inferencial;

- São apresentados na forma de diagramas, sendo muito importantes para os surdos, pois esses dependem de estímulos visuais para compreensão dos fenômenos que os cercam e do mundo.

Outra dificuldade do aluno surdo se refere à escrita do Português, língua essa, que deve ser tratada como segunda língua, porém não menos importante que a LIBRAS (primeira língua). Portanto, o aluno deve aprender dentro de um contexto bilíngue, ou seja, as aulas devem ser ministradas utilizando-se a LIBRAS para a comunicação dentro de sala entre professores e alunos e entre eles próprios. Isso faz com que o aluno compreenda de maneira efetiva o que está sendo estudado e passe a se comunicar melhor não apenas em sala de aula, mas também, dentro das várias relações interpessoais presentes em seu cotidiano, fazendo com que os mesmos possam ter maior autonomia em suas vidas pessoais. 
A Modelagem Qualitativa aparece aqui como uma proposta metodológica que permite ao aluno compreender melhor conceitos científicos e também melhorar a compreensão e a escrita do Português.

A utilização de modelos na mediação da aquisição do conhecimento auxilia também ao professor, que pode avaliar nos alunos: a compreensão do que foi abordado nos modelos; confecção de modelos; interpretação de textos explicativos sobre o que ocorre nos modelos; a utilização de verbos, pronomes e artigos nos textos escritos; entre vários outros indicativos do desenvolvimento e da compreensão do aluno sobre um determinado tema trabalhado, da escrita e dos conceitos científicos. 


\section{CAPÍTULO 1 - DESCRIÇÃO DO CURSO}

O curso tem como público alvo, estudantes surdos de escolas de Ensino Fundamental e Médio, sendo propostos encontros presenciais com duas horas aula cada. Dependendo do ritmo da turma, são necessários de seis a oito encontros realizados no turno contrário aos das aulas no ensino regular. Recomenda-se que o intervalo entre cada encontro não ultrapasse uma semana, pois isso pode afetar a sequência de compreensão sobre o que está sendo trabalhado com os alunos. Estes encontros são realizados no laboratório de informática da escola ou uma sala que possa ter no mínimo um computador para cada dois alunos.

O curso tem como objetivo geral dar suporte à aquisição de conceitos científicos; ao desenvolvimento do raciocínio lógico e; a compreensão e melhora da escrita da língua portuguesa. Para isso, são trabalhados os seguintes objetivos específicos:

- Desenvolver o raciocínio lógico por meio de situações que explorem o raciocínio hipotético-dedutivo.

- Trabalhar conceitos científicos utilizando modelos qualitativos;

- Compreender a dinâmica de sistemas ecológicos;

- Compreensão de fenômenos químicos, físicos e biológicos;

- Análise de situações cotidianas que geram impactos ambientais e a partir disso propor soluções;

- Aprimoramento da língua portuguesa na sua modalidade escrita.

Estes objetivos podem ser alcançados trabalhando-se diversos temas da Ecologia como:

- Recursos Hídricos;

- CiclodaÁgua,

- Poluição e contaminação da água potável;

- Tratamento do esgoto;

- Lixo e reciclagem;

- Usos do solo;

- Desenvolvimento humano e uso dos recursos naturais;

- Biodiversidade;

- Desmatamento, erosão e assoreamento.

- Preservação, uso sustentável dos recursos naturais e riquezas econômicas. 


\section{CAPÍTULO 2 - APRESENTAÇÃO DOS MODELOS QUALITATIVOS E DO SOFTWARE DYNALEARN}

Para iniciar o curso é necessário a instalação do software DynaLearnprecedido da instalação do SWI Prolog, indispensável ao funcionamento do DynaLearn.

Ambos estão disponíveis no site do projeto DynaLearn (https://ivi.fnwi.uva.nl/tcs/QRgroup/DynaLearn/) ou diretamente nos links a seguir:

- $\quad$ SWI-Prolog

http://www.swi-prolog.org/download/stableou no link SWI-Prolog.

- $\quad$ DynaLearn (Release 1.0.5)

https://ivi.fnwi.uva.nl/tcs/QRgroup/DynaLearn//SoftwarePublic/DynaLearn1.0.5.zipou no Link DynaLearn (Release 1.0.5)

Para o primeiro encontro é indicado que se faça uma apresentação do DVD "O uso de modelos Qualitativos no Ensino de Ciências", (FELTRINI, 2009), utilizando-se principalmente, a parte dos termos da modelagem presentes no glossário. Os sinais presentes nesse glossário já foram validados junto à comunidade surda e possui grande valia para o entendimento do que se propõe trabalhar com os alunos.

Nesse DVD, também está presente o modelo "Árvore e Sombra", que auxilia introduzir a dinâmica dos modelos e o pensamento sistêmico nos alunos.

O modelo 'Árvore e sombra' é bem didático, pois se trata de uma representação de um fenômeno conhecido por todos.

Nesse modelo estão representadas as primitivas da modelagem e que serão utilizadas ao longo das atividades aqui propostas. São elas: 'Entidade', 'Configuração', 'Quantidade', 'Derivada', Processos', 'Influências diretas + e - ( I+ e I-)' e 'Proporcionalidades qualitativas + e - ( P+ e P-)' . Estas duas últimas serão tratadas apenas como + ou - por estarmos utilizando o nível LS2, que é limitado no uso dessas duas ferramentas.

As 'Entidades' são os objetos envolvidos no sistema e que será foco da análise da variação de fatores ligados a esses objetos, na qual chamaremos de quantidades (ex.: árvore, solo).

Já as 'Configurações' são a descrição da relação entre entidades (ex.: árvore cresce sobre solo). 
As 'Quantidades' são variáveis que representam propriedades das entidades (ex.: biomassa da entidade 'Árvore'; área de sombra da entidade 'Solo')

O Processo é o mecanismo que determina alguma mudança no sistema. Nos modelos que estamos estudando, parte-se do pressuposto de que todas as mudanças começam em processos (por meio de influências diretas) e se propagam para outras quantidades do sistema (por meio de proporcionalidades).

Já as 'Influências diretas' ( I+, I-) são representações da direção da causalidade (o sentido da seta) e de função matemática, em que o valor da quantidade taxa é somado ou subtraído do valor da quantidade influenciada. Isso permite que se faça uma representação de 'PROCESSOS'. (Ex.: taxa de crescimento $-(\mathrm{I}+) \rightarrow$ biomassa, ou seja, a 'taxa de crescimento' possui uma relação direta com a 'quantidade' 'biomassa', sendo que a variação da taxa de crescimento faz com que ocorra uma variação na 'biomassa' no mesmo sentido, portanto se a 'taxa de crescimento' 'Aumenta', então a 'biomassa irá aumentar também e se o inverso ocorrer, a 'taxa de crescimento 'diminuir', a 'biomassa' vai diminuir da mesma forma. Isso ocorre por ser uma relação de influência direta positiva. Já na 'influência direta negativa, tudo que ocorre com a 'taxa de crescimento' vai fazer com que ocorra o contrário com a biomassa, ou seja, se a 'taxa de crescimento' 'aumentar', a 'biomassa' irá 'diminuir' e vise e versa.

Nas 'Proporcionalidades qualitativas $(\mathrm{P}+, \mathrm{P}-)$ ' é possível fazer a representação de direção da causalidade (o sentido da seta) e da função matemática na qual a derivada da quantidade influenciada torna-se igual à da quantidade influenciadora, quando for $(\mathrm{P}+)$, ou contrária à da quantidade influenciadora, quando for $(\mathrm{P}-)$, sendo propagados os efeitos dos processos para outras quantidades.

Por fim, as 'Derivadas' indicam a variação ou não de uma determinada quantidade, podendo 'Aumentar', 'Diminuir' ou permanecer 'Estável'. Como estaremos utilizando o LS2, essa última só ocorrerá caso não varemos nenhuma das quantidades iniciais, pois nesse nível de modelagem não é possível representar um processo com retroalimentação (ou feedback) e nem limitar a cadeia de influências representadas nas relações diretas entre as quantidades representadas.

Para compreendermos melhor o que foi dito, a seguir serão descritas as partes do modelo acompanhado da representação, no software DynaLearn, do modelo 'Árvore e sombra' e do objetivo desta atividade. 
A configuração entre as entidades:

\begin{tabular}{|c|c|c|}
\hline Entidade fonte & Configuração & Entidade Alvo \\
\hline Árvore & Cresce sobre & Solo \\
\hline
\end{tabular}

Quantidades e derivadas:

\begin{tabular}{|l|c|c|}
\hline Entidade & Quantidade & Derivada \\
\hline \multirow{2}{*}{ Árvore } & Taxa de crescimento & Aumenta, estabiliza,diminui \\
\cline { 2 - 3 } & Biomassa (Tamanho) & Aumenta, estabiliza,diminui \\
\hline \multirow{2}{*}{ Solo } & Tamanho da Sombra & Aumenta, estabiliza,diminui \\
\cline { 2 - 3 } & Temperatura no solo & Aumenta, estabiliza,diminui \\
\hline
\end{tabular}

Representação do modelo no software DynaLearn

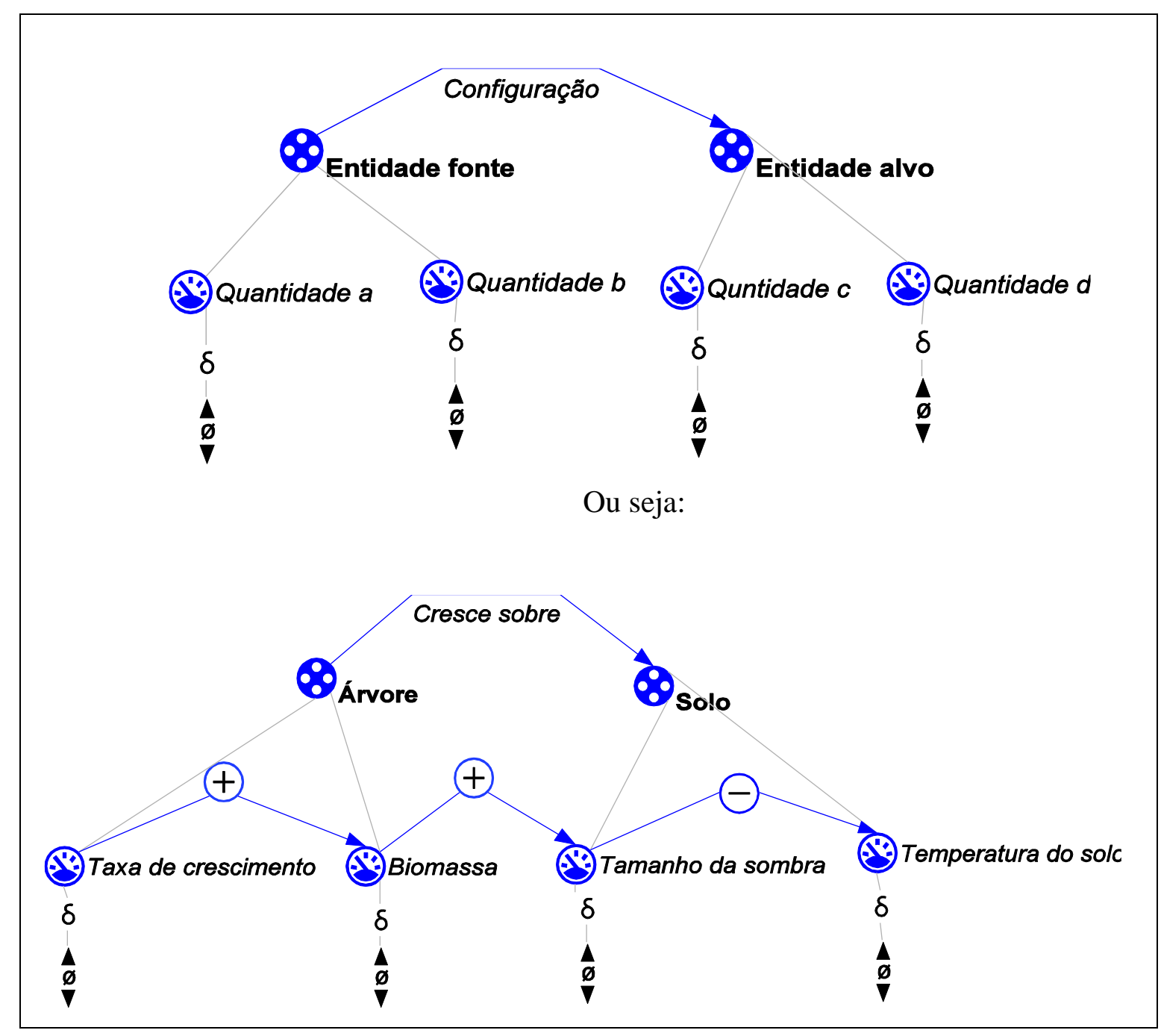

Para construir o modelo como apresentado acima, consulte o Tutorial 1 na página 34 e o Tutorial 2 na página 36 desta proposta. 
Realiza-se então uma simulação selecionando uma das derivadas da quantidade como apresentado abaixo:

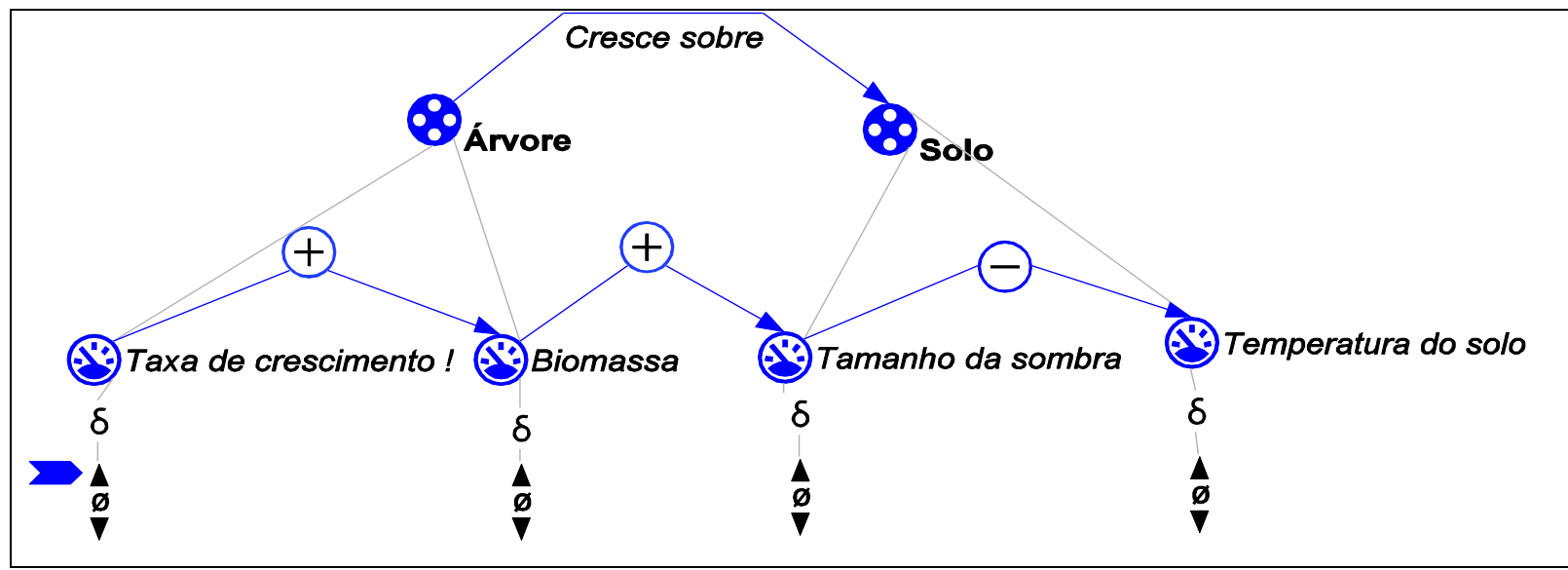

(Na página 41 desta proposta consta um roteiro para se rodar simulações. Consulte caso necessário.)

Esperamos que o efeito de aumento da taxa de crescimento se propague pelo modelo devido a relação de causalidade estabelecida pelas influências positivas e negativas entre as quantidades relacionadas. Como resultado dessa simulação teremos o seguinte quadro:

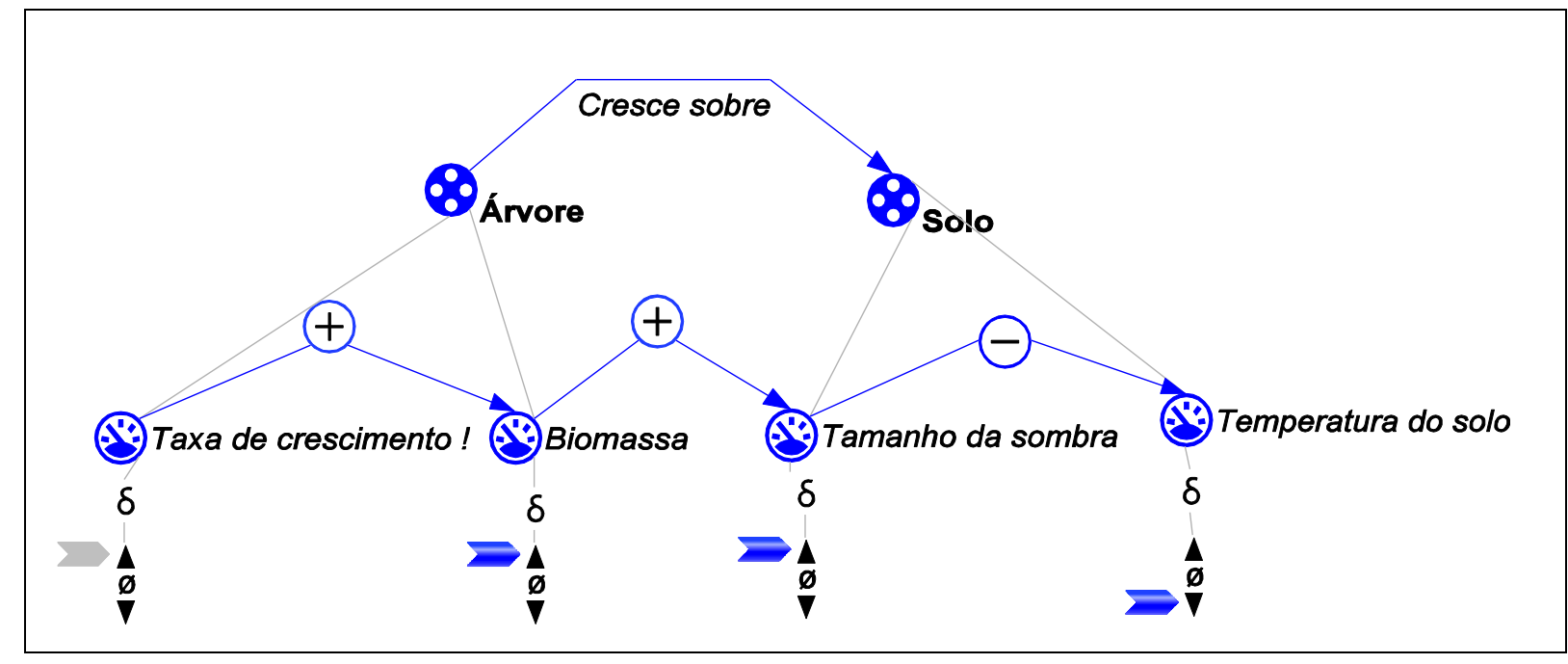

Os resultados foram dados como esperado. Pois ao aumentar a 'taxa de crescimento' da entidade 'árvore', a relação 'positiva' estabelecida entre está quantidade e a quantidade 'biomassa', faz com que ela aumente também. Com isso, o aumento da 'biomassa', aumenta o 'tamanho da sombra' da árvore sobre o solo, pois há entre essas quantidades uma relação de influência 'positiva'. Já a temperatura vai diminuir, pois há uma relação de influência 'negativa' entre o 'tamanho da sombra' sobre o solo e a quantidade 'temperatura'. Trocando em palavras simples, quanto maior for a biomassa da copa de uma árvore, mais sombra ela fará e com isso a temperatura sobre o solo vai diminuir. 
Após o uso do modelo de forma explicativa, será possível avaliar como os alunos compreendem a relação dos fenômenos presentes no modelo e as relações de causalidade que ocorrem quando a árvore cresce ou diminui e como esses fenômenos interferem na temperatura do solo. Essa avaliação pode ser feita utilizando perguntas do tipo "Se... Então...", como nos exemplos abaixo:

\section{Julgue os itens abaixo utilizando (V) para Verdadeiro e (F) para Falso: \\ 1 - ( F ) SE Sombra aumenta, ENTÃO a Temperatura aumenta. \\ 2 - ( F ) SE o Tamanho da árvore aumenta, ENTÃO a Sombra diminui.}

Já para avaliar como está o nível de escrita dos alunos e se eles realmente compreenderam o que foi apresentado, podem ser utilizadas questões do tipo subjetiva em que eles devem escrever pequenos textos como respostas, utilizando os termos "SE" e "ENTÃO", para descrever um fenômeno representado por umafigura, como apresentada a seguir':

Descreva o que está acontecendo nas ilustrações abaixo.
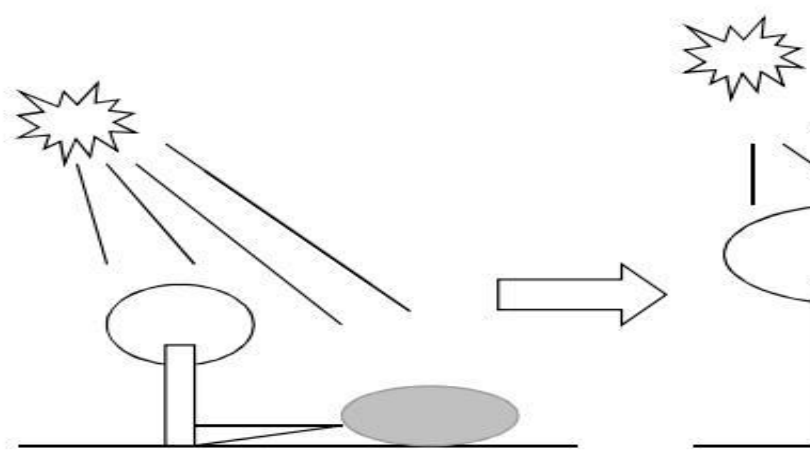

Essa atividade permite que os alunos se envolvam de forma ativa na resolução dos problemas representados, o que favoreceu entendimento da dinâmica do sistema presente no modelo representado por imagem.

Ao final do encontro podem ser entregues tutoriais de como se instalar o software DynaLearn, a fim de que os alunos possam instalar em seus computadores pessoais e havendo interesse, possam dar sequência ao aprendizado em suas casas.

\footnotetext{
${ }^{1}$ Figura extraída de Salles et al. (2013, p.16).
} 
Para os encontros seguintes, será utilizado o modelo 'Desmatamento', criado no nível LS2, porém baseado em um modelo desenvolvido em LS6 pelo projeto LAPEVI².

${ }^{2}$ LAPEVI - Laboratório de Pedagogia Visualé um produto do Projeto“Laboratório de Pedagogia Visual para a Educação Bilíngue de Surdos - Libras/Português" financiado por meio de Convenio entre o Ministério da Ciência, Tecnologia e Inovação e a Universidade de Brasília (ação 8976-MCT-Processo 01200.004623/2010-48), e conduzido por Professores do Instituto de Letras (Departamento de Linguística, Português e Línguas Clássicas) e Instituto de Ciências Biológicas (Núcleo de Educação Científica do IB - NECBio). Outro produto do Projeto LAPEVI é o manuscrito referido nesta proposta como Salles et al. (2013). 


\section{CAPÍTULO 3 - O MODELO 'DESMATAMENTO'}

O desmatamento é um tema bastante atual e tem levado a vários debates sobre seus efeitos no mundo todo. Um dos problemas que está relacionado ao desmatamento é a escassez de água potável e seu uso para a produção de alimento, consequentemente, afetando o homem em sua subsistência e economicamente também. Por isso, o modelo 'Desmatamento' foi desenvolvido para demonstrar as relações causais do efeito do desmatamento sobre a vegetação, o solo, os recursos hídricos, produção de alimentos e remédios, bem como os efeitos destes sobre a população humana(SALLES et al. 2013).

\section{Estrutura do modelo 'DESMATAMENTO'}

Configurações:

\begin{tabular}{|c|c|c|}
\hline Entidade fonte & Configuração & Entidade Alvo \\
\hline Vegetação & Protege a & Terra \\
\hline Vegetação & Sustenta o & Homem \\
\hline Terra & Contém & Água \\
\hline Terra & Sustenta o & Homem \\
\hline Água & Sustenta o & Homem \\
\hline
\end{tabular}

Quantidades e derivadas:

\begin{tabular}{|l|c|c|}
\hline \multicolumn{1}{|c|}{ Entidades } & Quantidades & Derivadas \\
\hline \multirow{4}{*}{ Vegetação } & Desmatamento & Aumenta, estabiliza,diminui \\
\cline { 2 - 3 } & Terra com Vegetação & Aumenta, estabiliza,diminui \\
\cline { 2 - 3 } & Terra sem Vegetação & Aumenta, estabiliza,diminui \\
\cline { 2 - 3 } & Biodiversidade & Aumenta, estabiliza,diminui \\
\cline { 2 - 3 } & Erosão & Aumenta, estabiliza,diminui \\
\cline { 2 - 3 } & Terra carregada & Aumenta, estabiliza,diminui \\
\cline { 2 - 3 } & Produção de milho & Aumenta, estabiliza,diminui \\
\hline \multirow{2}{*}{ Água } & Reservatório de água & Aumenta, estabiliza,diminui \\
\cline { 2 - 3 } & Usos da água & Aumenta, estabiliza,diminui \\
\hline \multirow{3}{*}{ Homem } & População sem água & Aumenta, estabiliza,diminui \\
\cline { 2 - 3 } & Alimentos e remédios & Aumenta, estabiliza,diminui \\
\cline { 2 - 3 } & Riqueza econômica & Aumenta, estabiliza,diminui \\
\hline
\end{tabular}

As quantidades presentes nos modelos se relacionam por meio de influências que são representadas por 'Positivas' (+), quando a variação de uma quantidade ocorre no mesmo sentido da variação da quantidade que a influencia e 'Negativas'(-), quando a variação de uma 
quantidade ' $A$ ' influencia a alteração da quantidade ' $B$ ' com a qual se relaciona com um sentido inverso, ou seja, se a primeira quantidade aumenta, a que sofre influência dessa, irá diminuir. Essas influências estão representadas pelos sinais de (+) e (-) como no modelo do 'Desmatamento' a seguir:

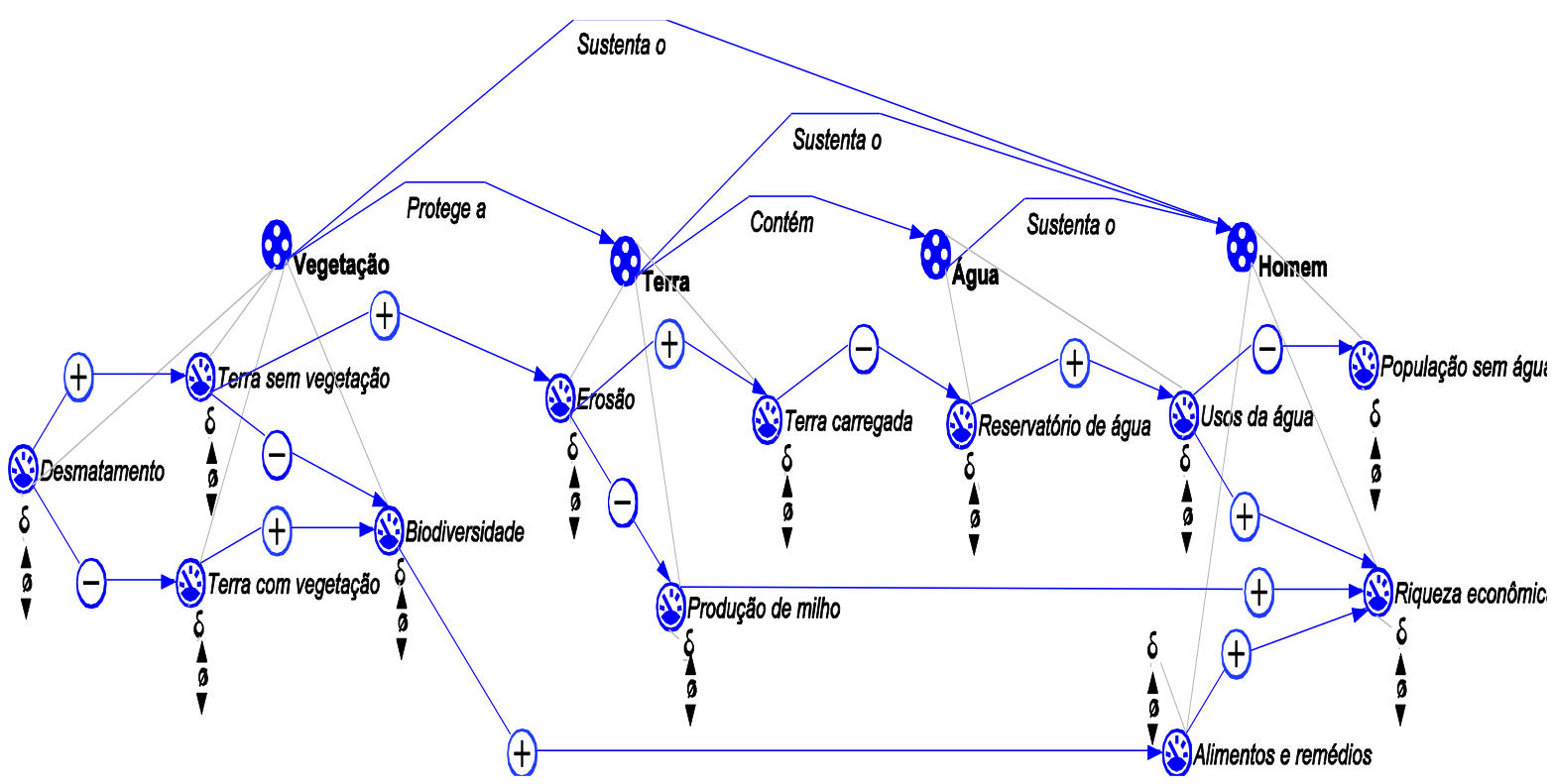

Para tornar mais compreensivo os modelos para os alunos surdos, é necessário adaptar a maneira como são tratados os conceitos abordados. Para atender a uma proposta de metodologia que explora aspectos da Pedagogia visual, os conceitos utilizados nos modelos foram apresentados por meio do uso de imagens seguidos dos conceitos explicados por meio de sinais já validados junto à comunidade surda. Essas imagens, também foram extraídas do material produzido pelo LAPEVI e os sinais foram extraídos do DVD instrucional "O uso de modelos Qualitativos no Ensino de Ciências", (FELTRINI, 2009). As imagens utilizadas para se trabalhar os conceitos foram:

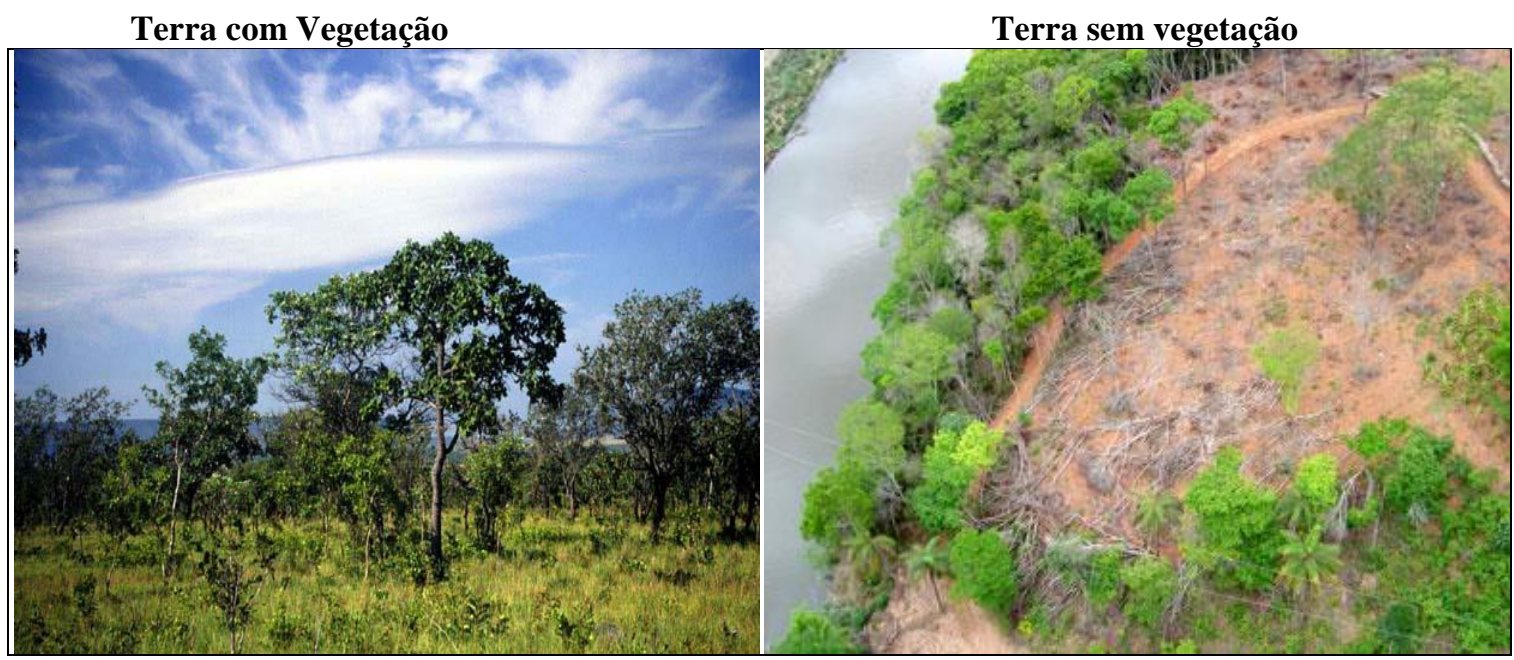




\section{Desmatamento}

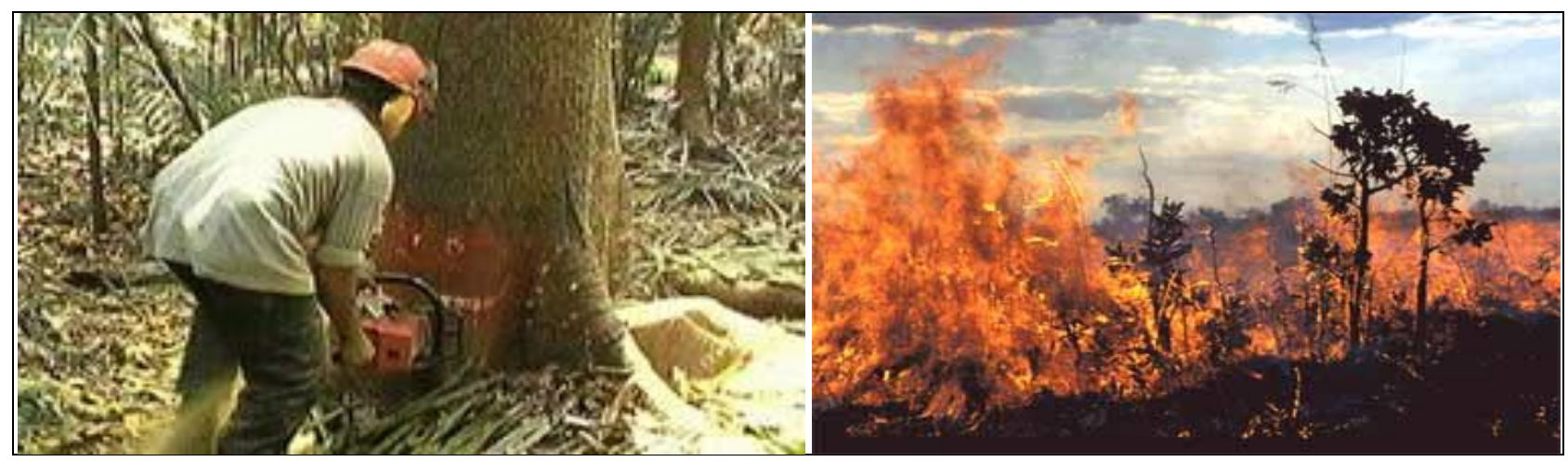

Biodiversidade
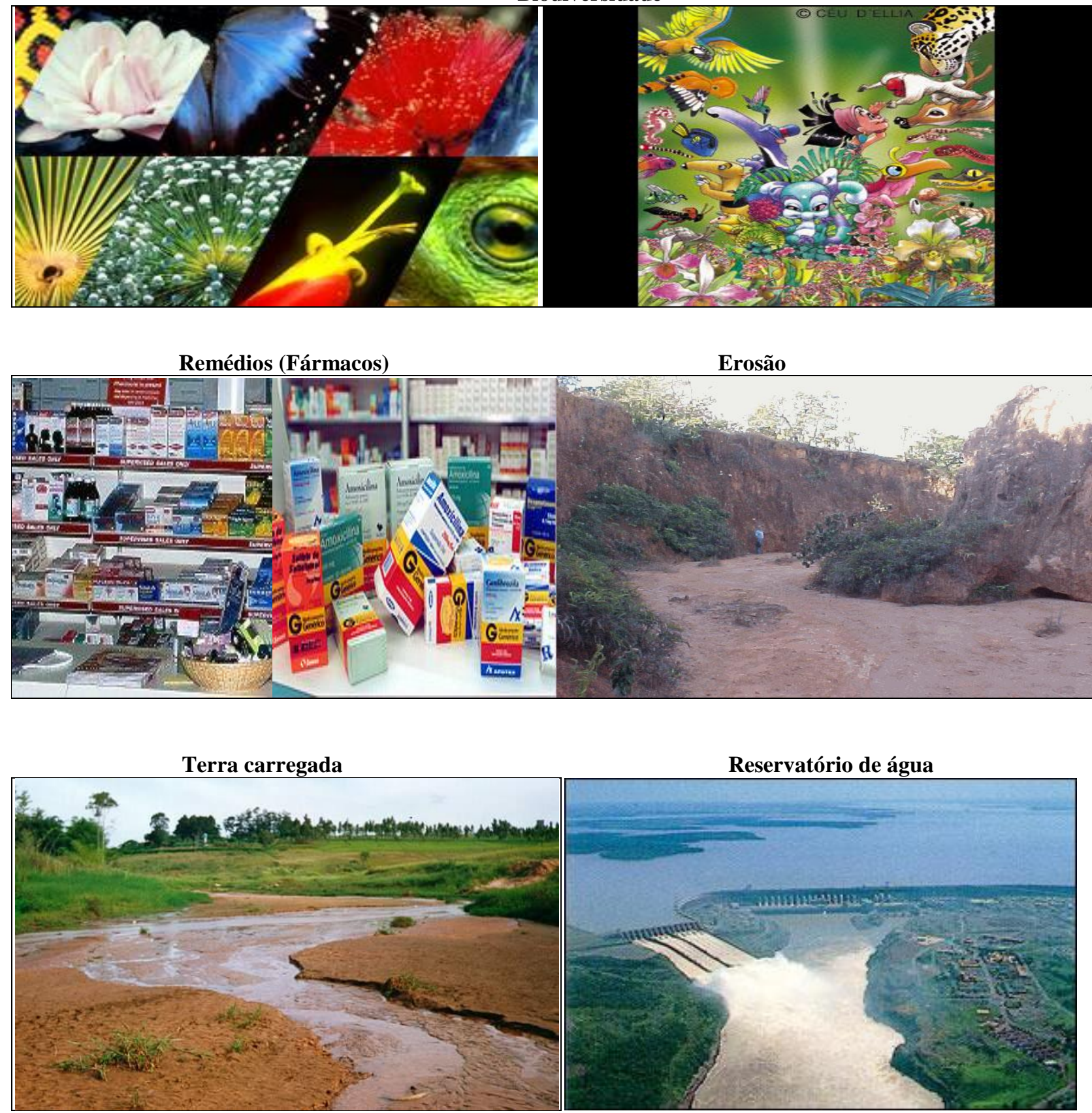
Usos da água

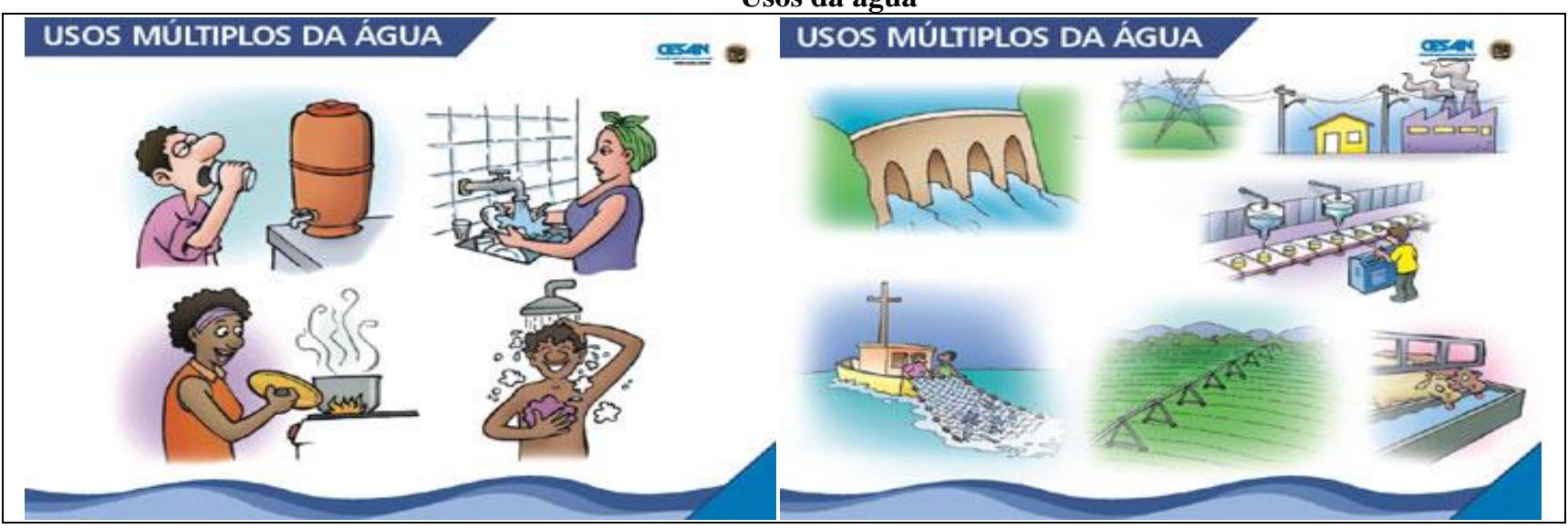

Produção agrícola

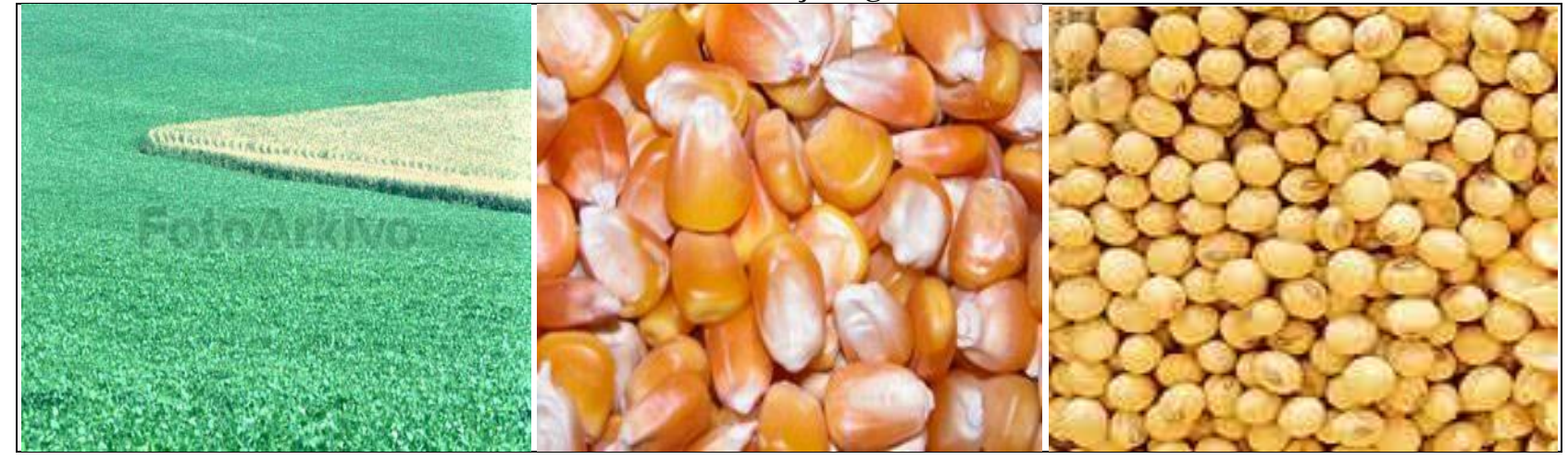

População sem água

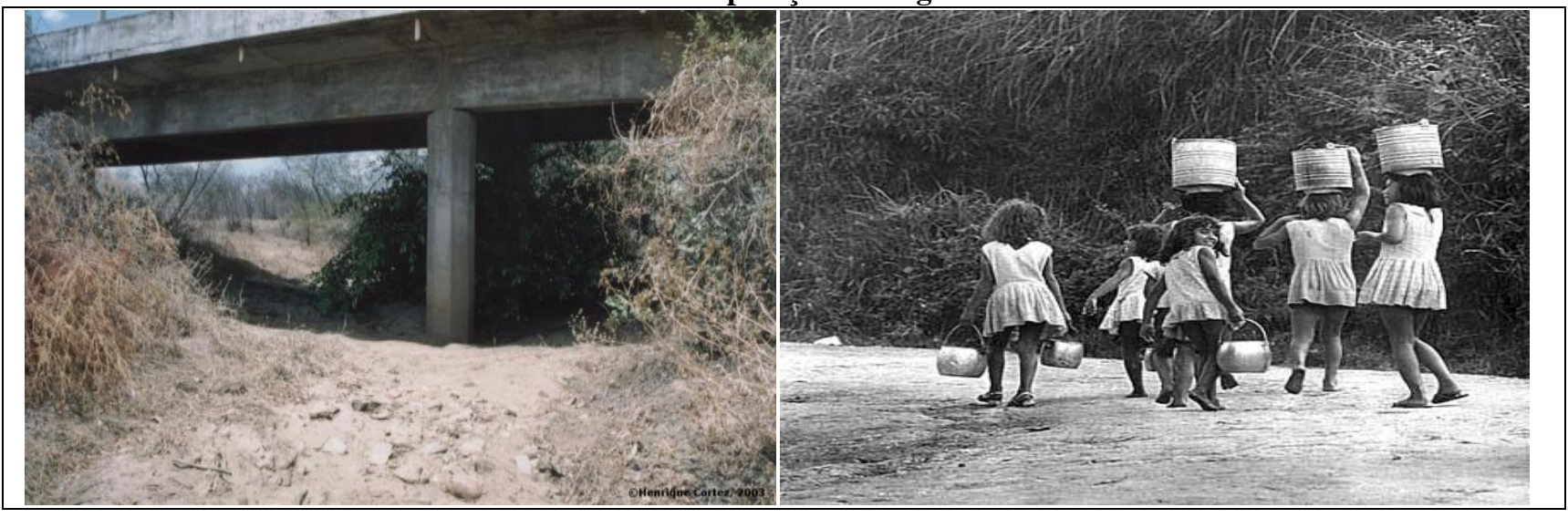

Riqueza econômica

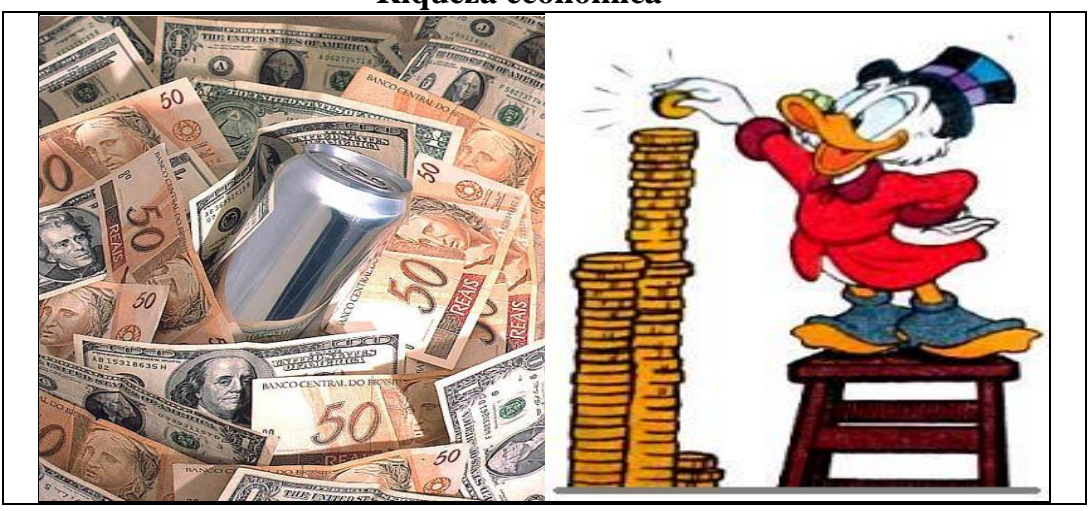




\section{USANDO A LÓGICA}

A palavra Lógica, no linguajar comum, significa aquilo que é o óbvio. Já para a filosofia e para ciência, a Lógica são procedimentos para tirar conclusões de premissas ou analisar argumentos.

Existem várias vantagens no uso da lógica para se resolver e compreender situações problema, entre elas estão: a distinção entre o essencial e o supérfluo e a distinção entre o geral e o particular.

Ao trabalharmos o Raciocínio lógico é importante termos conhecimento do que são Silogismos. O Silogismo apresenta uma estrutura formada por um argumento-padrão composto por duas premissas e uma conclusão. Essa estrutura permite que uma pessoa possa fazer deduções a partir de informações prévias levando-o a concluir algo que não está diretamente explícito em uma dada afirmativa. A seguir são apresentadas algumas imagens contendo a estrutura e exemplos de Silogismo:
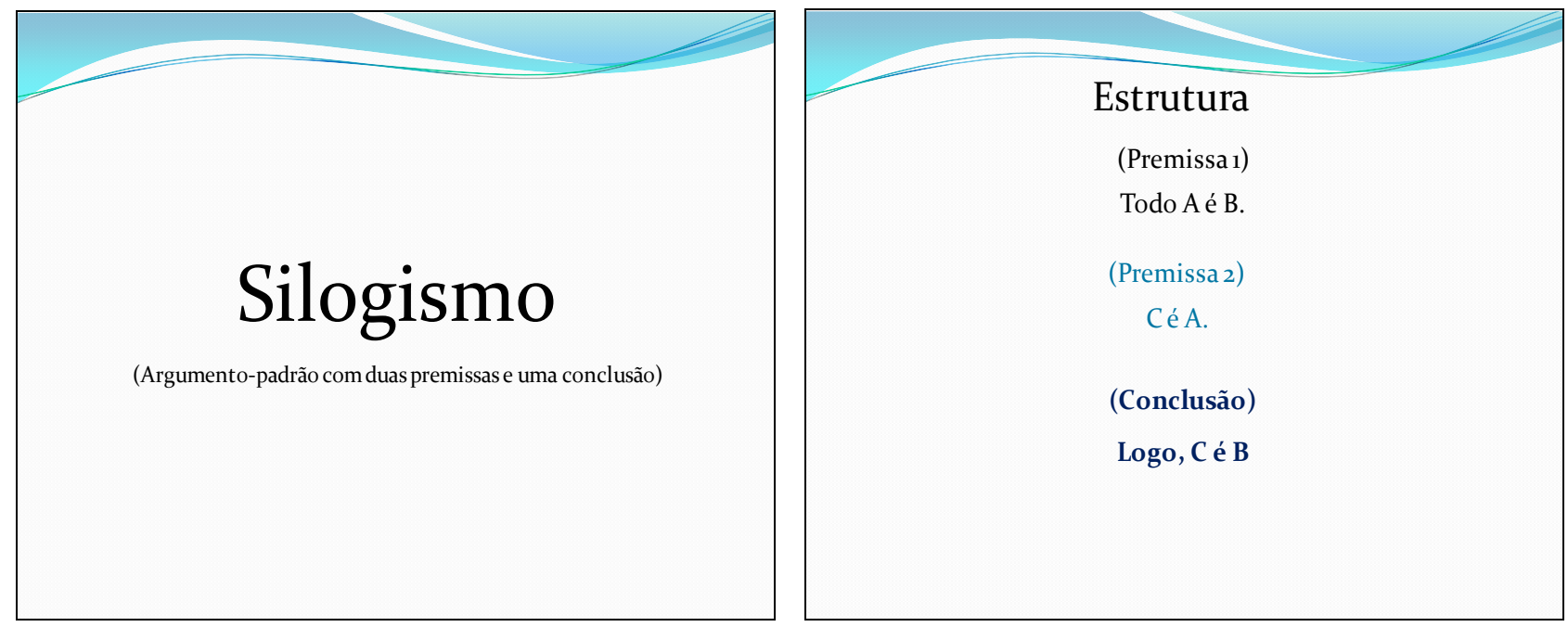

\section{Exemplos:}
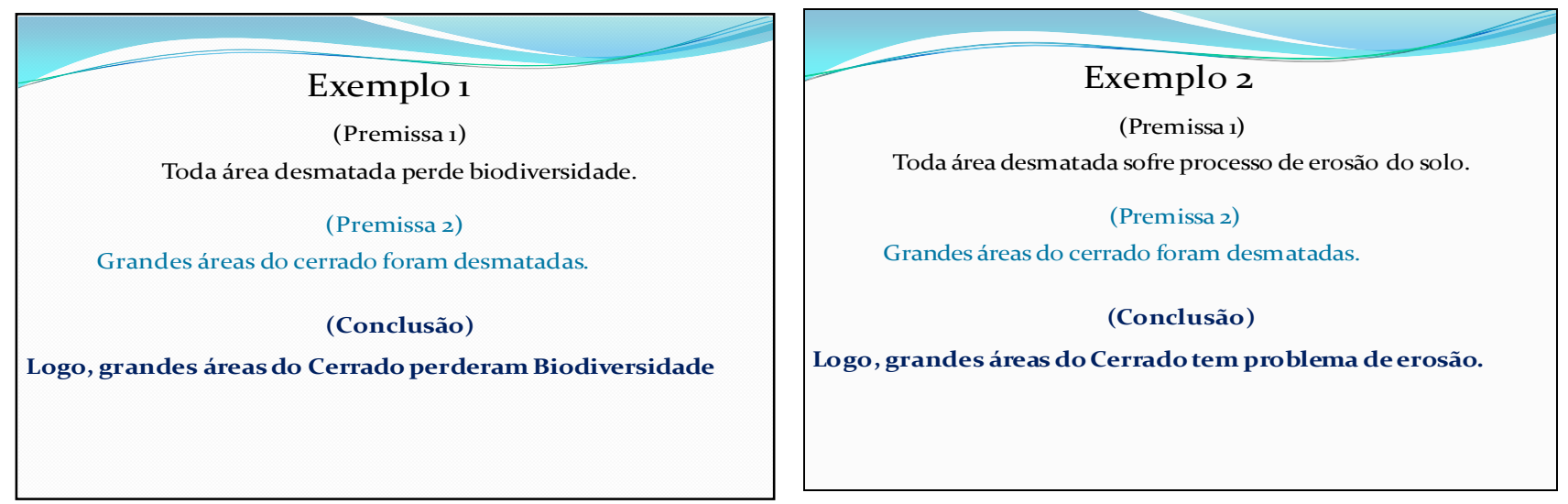
Ao avaliar a compreensão dos silogismos presentes nas questões do tipo 'Se... Então...', foi possível observar uma grande desenvoltura por parte dos alunos no entendimento de situações em que exigia-se deles um raciocínio hipotético dedutivo, que muitas vezes não estavam explícitos nos modelos.

\section{Uso do ‘Se... Então...' no desenvolvimento do raciocínio hipotético-dedutivo}

Introduzido o modelo e os conceitos a serem trabalhados, pode-se passar para uma etapa seguinte, que é a representação informal dos fragmentos de modelos por meio de frases do tipo 'Se... Então...', para explicar as relações causais existentes entre as quantidades representadas de cada entidade presente no modelo. Essas afirmativas demonstram os efeitos e as consequências do desmatamento, por meio de afirmações simples e que possui apenas uma relação de causalidade, que pode estar direta ou indiretamente ligadas ao desmatamento. Abaixo estão representadas algumas das afirmações ${ }^{3}$ (transcritas de Salles et al., 2013) que podem ser utilizadas junto aos alunos:

Se ...aumenta o 'Desmatamento',

Então ...diminui a'Terra com Vegetação’.

Se ...aumenta o 'Desmatamento',

Então ....aumenta a 'Terra sem Vegetação'.

Se ...aumenta a 'Erosão',

Então ....aumenta o 'Terra carregada' para os rios.

$\underline{\text { Referente à perda da biodiversidade, pode-se afirmar: }}$

Se ...diminui a 'Biodiversidade',

Então ...diminui a chance de se descobrir novos 'Fármacos'.

Se ...diminui a chance de se descobrir novos 'Fármacos',

Então ...diminui a 'Riqueza econômica'.

Se ...diminui a 'Biodiversidade',

Então ...diminui a chance de se encontrar novos 'Alimentos'.

Se ...diminui a chance de se encontrar novos 'Alimentos',

Então ...diminui a capacidade de gerar 'Riquezas econômicas'.

Em relação aos danos causados ao solo pode-se afirmar:

Se ...aumenta o 'Desmatamento',

Então ....aumenta a 'Terra sem vegetação'.

\footnotetext{
${ }^{3}$ Trechos transcritos de Salles et al. (2013, pp. 45-49).
} 
Se ....aumenta a 'Terra sem vegetação',

Então ...aumenta a 'Erosão' no solo.

Se ...aumenta a 'Erosão' no solo,

Então ...diminui a 'Produção de milho'.

Se ...diminui a 'Produção de milho',

Então ...diminui a 'Riqueza econômica'.

O desmatamento pode causar também o assoreamento de rios o que leva a concluirmos que:

Se ...aumenta a 'erosão' no solo,

Então ....aumenta a quantidade de 'Terra carregada' para dentro dos rios.

Se ...aumenta a quantidade de 'Terra carregada' para dentro dos rios,

Então ....diminui os 'Reservatórios de água'.

Se ...diminui os 'Reservatórios de água',

Então ....diminui o 'Usos d água'.

Se ...diminui o 'Usos d água',

Então ...aumenta a 'População sem água'.

Se ...diminui o 'Usos d água',

Então ...diminui a 'Riqueza econômica'.

Podemos inferir outras afirmativas além das que estão presentes nos modelos, pois os efeitos do desmatamento no solo também podem levar a formação de 'Erosão' e essa pode afetar ao solo de diversas maneiras, a respeito disso pode-se afirmar:

Se ....aumenta o 'Desmatamento',

Então ....aumenta a 'Erosão' do solo.

Se ....aumenta a 'Erosão' do solo,

Então ...diminui a 'Fertilidade' do solo.

Se ...diminui a 'Fertilidade' do solo,

Então .... diminui a 'Produtividade' do solo.

Se ...diminui a 'Produtividade' do solo,

Então ...diminui a 'Produção agrícola'.

Se ...diminui a 'Produção agrícola',

Então ....aumenta o 'Desemprego' no campo.

Se ...aumenta o 'Desemprego' no campo,

Então ....aumenta o 'Êxodo rural'.

Se ...aumenta o 'Êxodo rural',

Então ....aumenta o 'Desemprego' nas cidades.

Se ...aumenta o 'Desemprego' nas cidades,

Então ...aumenta a 'Violência' nas cidades.

$\underline{\text { O desmatamento pode causar também o assoreamento de rios o que leva a concluirmos que: }}$

Se ...aumenta o 'Assoreamento' do rio,

Então ...diminui a 'Quantidade de água' no rio. 
Se ...aumenta o 'Assoreamento' do rio,

Então ...diminui a 'Qualidade da água' no rio.

Se ...aumenta o 'Assoreamento' do rio,

Então ...diminui a 'Profundidade' do rio.

Se ...diminui a 'Profundidade' do rio,

Então ...diminui o 'Transporte de cargas' no rio.

Se ...diminui o 'Transporte de cargas' no rio,

Então ....aumenta o 'Desemprego' na comunidade.

Outro efeito do desmatamento são as mudanças climáticas, o que leva a afirmar:

Se ...aumenta o 'Desmatamento',

Então ...ocorrem‘Mudanças climáticas’.

Se ....aumenta o 'Desmatamento',

Então ...diminuem as 'Chuvas' na região.

Se ...diminuem as 'Chuvas' na região,

Então ...diminui a 'Produção agrícola'.

Se ...diminui a 'Produção agrícola',

Então ....aumenta o 'Desemprego' no campo.

Se ...aumenta o 'Desemprego' no campo,

Então ....aumenta o 'Êxodo rural'.

Se ....aumenta o 'Êxodo rural',

Então ....aumenta o 'Desemprego' nas cidades.

Se ....aumenta o Desemprego' nas cidades,

Então ....aumenta a 'Violência' nas cidades.

\section{VOCABULÁRIO ${ }^{4}$ E TERMOS EM ECOLOGIA}

Biodiversidade- Variedades de espécies de seres vivos encontradas em uma região Inclui diversidade entre indivíduos da mesma espécie, diversidade de espécies, diversidade de comunidades e diversidade de ecossistemas.

Erosão - Processo de transporte de solo de um lugar para outro, em geral pela água ou pelo vento. Como resultado, fica um buraco ou um sulco no chão.

Assoreamento - Deposição de terra (solo e areia) no leito dos rios e lagos. Como consequência o leito do rio se torna mais raso.

Preservação - Processo de manutenção de espécies ou de ecossistemas com suas características naturais ao longo do tempo

\footnotetext{
${ }^{4}$ Trechos transcritos de Salles et al. (2013, pp. 50-54).
} 
Conservação - Proteção de espécies comunidades ou ecossistemas, mas admite que os recursos naturais possam ser utilizados pelo homem.

Fármacos - Substâncias químicas que são ou podem ser usadas como remédios.

Exemplo: A Maracujina é uma substância extraída do maracujá e usada na produção de remédios calmantes.

Matéria prima - Material que pode ser usado para a fabricação de algum produto.Exemplo: A seiva da árvore conhecida por seringueira é usada para a fabricação deborracha.

Infiltração da água no solo - Movimento da água que cai na superfície do solo para o subsolo.Exemplo: Quando chove, uma parte da água se infiltra na terra.

Lençóis freáticos - Reservatórios de água no subsolo. Exemplo: A água que se retira de um poço é água que estava acumulada no lençolfreático.

Êxodo rural - Movimento de pessoas que deixam o campo e se mudam para as cidades.

Evaporação - Processo de transformação de substância líquida em vapor.

\section{$\underline{\text { EXERCÍCIOS }}$}

\section{Complete as lacunas:}

Toda área desmatada sofre erosão.

Grandes áreas do cerrado foram desmatadas.

Logo, grandes áreas do cerrado apresentaram

Todo rio com problemas de assoreamento sofre perda na capacidade de reservar água.

Rios do cerrado têm problemasde assoreamento

Logo,

Se ...aumenta o 'Desmatamento',

Então ... a 'Erosão' no solo.

Se ...aumenta a 'Erosão' no solo,

Então ... a 'Produção agrícola'.

Se ...diminui a 'Produção agrícola',

Então ... a 'Produção de milho'.

Se ...diminui a 'Produção de milho',

Então ... a riqueza econômica. 


\section{CÁPITULO 4 - MODELOS EM UM FORMATO VISUAL}

Sabemos que o desmatamento causa grande dano à biodiversidade e pode causar problemas no solo levando principalmente a erosões, essas por sua vez, são causadas pelo deslocamento de material sólido que normalmente é arrastado para dentro de rios e lagos reduzindo a sua capacidade de armazenar água. Todos esses eventos acabam por prejudicar os interesses humanos de alguma forma, seja pela redução da capacidade de se produzir alimentos ou a redução da capacidade de usos da água para fins pessoais ou até mesmo de produção de alimentos, pois afeta a capacidade de irrigação de cultivos. Indo mais fundo nessa análise, podemos afirmar que a população acaba ficando mais pobre e com menos qualidade de vida, pois os menos favorecidos acabam por ficarem sem acesso à água e os alimentos tornam-se mais caros, sem falar no desemprego devido a uma grande ocorrência de êxodo rural e o inchaço populacional das cidades. Ou seja, o homem acaba sendo prejudicado de diversas formas, tudo desencadeado lá no início por um processo de retirada da cobertura vegetal do solo por meio da exploração desordenada da madeira ou para se criar grandes áreas de plantio ou criação de pastagem para animais.

Como se vê, a exploração sustentável do ambiente é algo de fundamental importância para a vida de todos, sendo assim a comunidade surda não poderia ficar de fora de questões tão importantes como essa. A fim de incluir essa comunidade no debate e no pensar ecológico, o modelo aqui trabalhado tem que oferecer condições para ser entendido por esse público. Com esse intuito, as relações sistêmicas serão apresentadas de forma visualmente adaptadas, levando o aluno a ser capaz de utilizar modelos para analisar questões que interferem direta ou indiretamente em suas vidas e então, poderem propor soluções a partir das análises feitas nos modelos.

Apresentados os conceitos contidos no modelo por meio de afirmativas do tipo 'Se... Então... ', utilizam-se as imagens para criar relações que se pretende demonstrar com o uso dos modelos. Isso pode ser feito com a combinação das imagens ${ }^{5}$ como apresentado a seguir:

\footnotetext{
${ }^{5}$ Adaptado de Salles et al. (2013, pp. 64-66).
} 


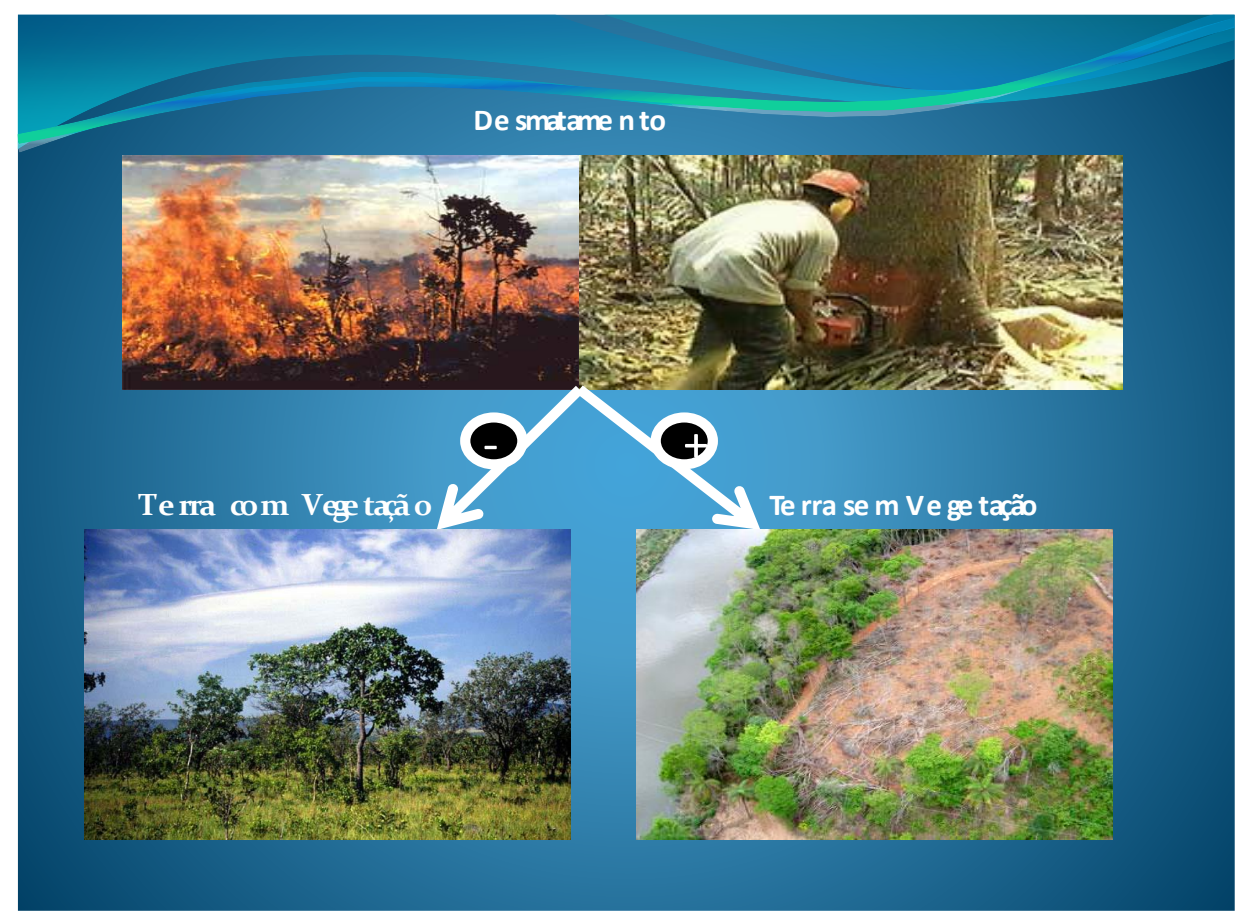

A imagem mostra as relações entre o desmatamento e as quantidades 'Terra com Vegetação' e 'Terra sem Vegetação'. Nota-se que na primeira, há uma relação de proporcionalidade negativa, ou seja, Se o 'desmatamento' aumenta, Então a 'Terra com Vegetação' diminui. A proporcionalidade positiva representada para a 'Terra sem Vegetação' faz com que Se o 'Desmatamento' aumentar, ocorra o mesmo com a quantidade 'Terra sem Vegetação'.

A imagem permite ao aluno visualizar claramente os conceitos trabalhados, além de dar uma visão de parte das relações que são abordadas no modelo.

Em seguida, são feitas perguntas que exploram o raciocínio lógico dos alunos, de forma a verificar as relações de causalidade presentes no sistema representado a partir de uma informação inicial a respeito do desmatamento, como nas perguntas abaixo: vegetação?

Se o Desmatamento aumentar, o que ocorre com a Terra com Vegetação? E com a Terra sem

Se a Terra com vegetação diminui o que ocorre com as erosões?

O mesmo pode ser feito para avaliar os alunos, seja fazendo uso de questões do tipo “Se...Então...” ou com perguntas de completar, como apresentada a seguir:

1- A Terra com Vegetação AUMENTOU, Porque o Desmatamento DIMINUIU.

2- A Erosão AUMENTOU, Porque o Desmatamento AUMENTOU. 
Nota-se que nessa última questão é necessário um pensamento mais elaborado para poder se responder, pois não se trata de uma relação direta entre o desmatamento e a erosão, portanto, trata-se de uma resposta não trivial e que exige um raciocínio mais apurado do aluno, ou seja, o aluno faz uso do raciocínio e responde por meio de suas deduções a respeito do fenômeno observado como um todo.

Na sequência, é explorado o uso de Silogismo e do raciocínio dedutivo com o auxílio de imagens e de fragmentos de modelos, representando afirmativas que estimulam os alunos a pensar de forma mais elaborada e de maneira não trivial.

A seguir são apresentadas as imagens contendo as relações causais a cerca dos efeitos do desmatamento e suas consequências diretas e indiretas.

A figura abaixo mostra um fragmento de modelo que estimula o aluno a pensar, qual seria o efeito do aumento do desmatamento sobre o processo de erosão do solo.

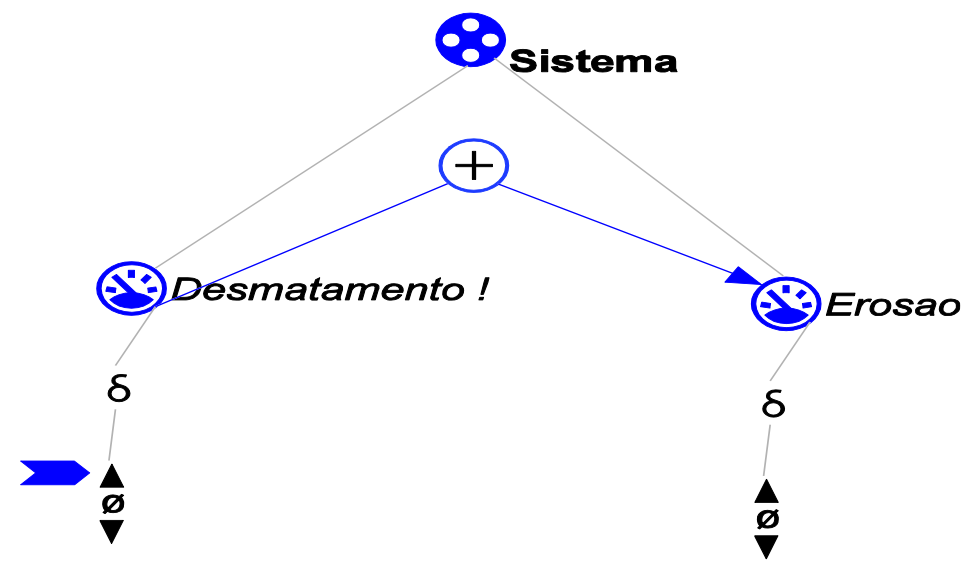

A mesma situação pode ser representada com o uso de imagens demonstrando que a cadeia de eventos leva a uma conclusão, que o desmatamento afeta o solo, deixando-o desprotegido da ação do vento e da chuva, e consequentemente, parte do material do solo é arrastado, causando erosões.

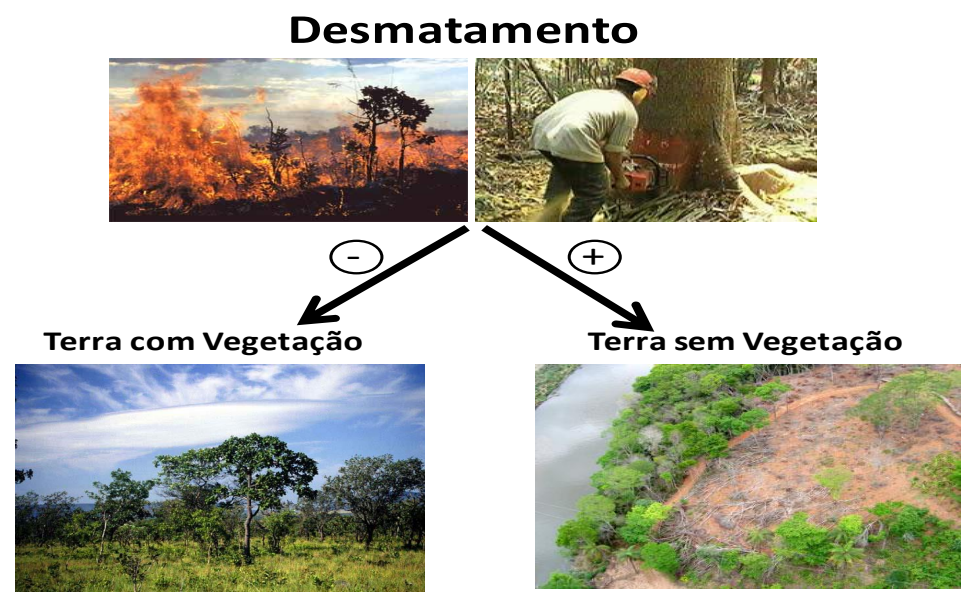


Nota-se na imagem abaixo, uma relação de proporcionalidade inversa entre a quantidade de 'Terra com Vegetação' e a de 'Terra sem Vegetação. Essa equivalência pode ser percebida na relação em que uma quantidade aumenta e a outra reduz, na mesma proporção.

\section{Terra com e sem vegetação}

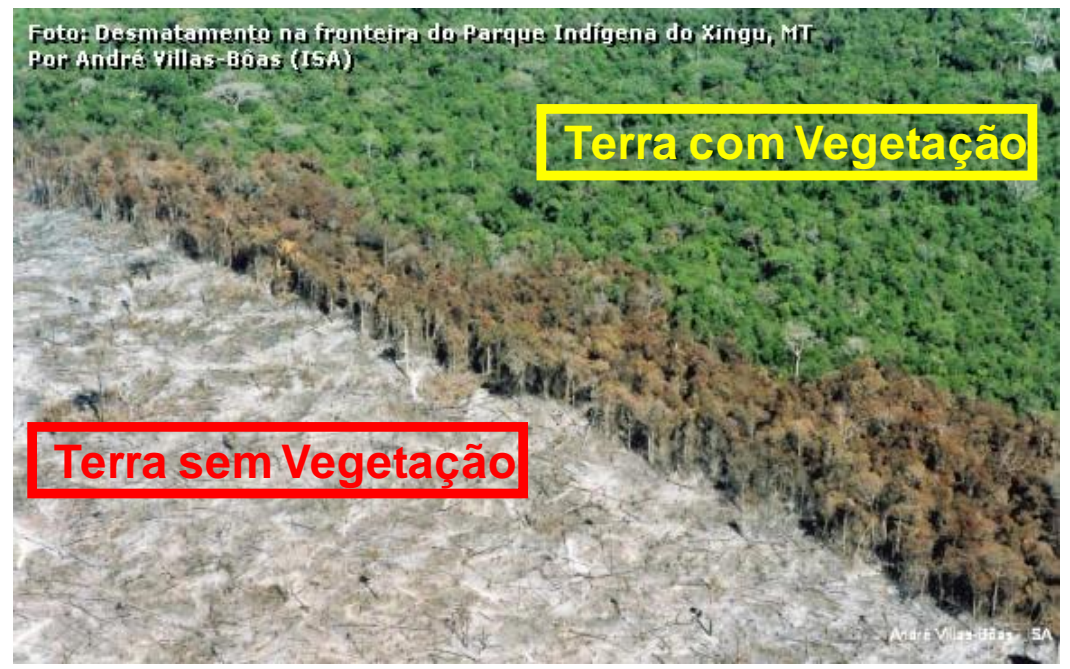

Ao se reduzir a cobertura vegetal do solo, a terra fica desprotegida e, consequentemente, a ação dos ventos e da água, levam à formação de erosões.

\section{Terra sem vegetação e Erosão}

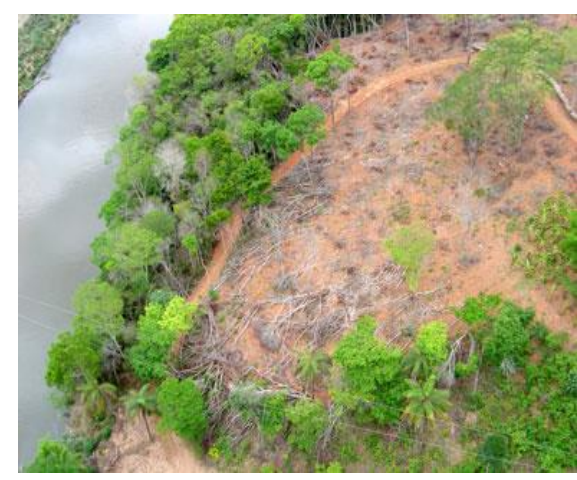

Terra se $m$ ve ge tação

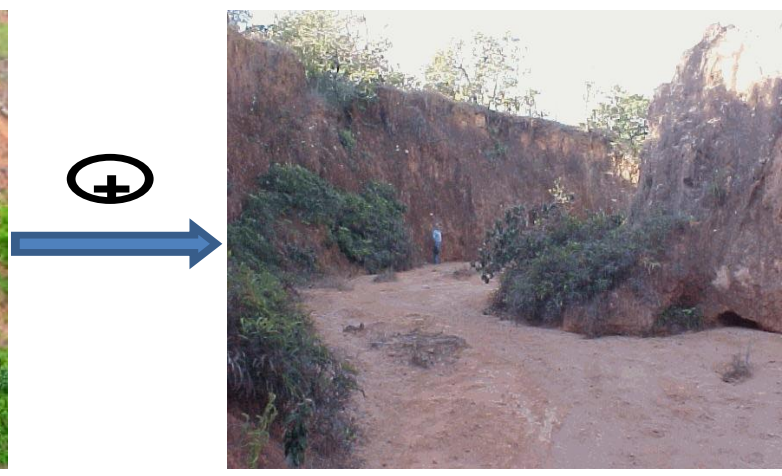

Erosão 
Por sua vez, a erosão se deve a um volume de material retirado do solo (terra e areia), que são arrastados e levados a outro lugar.

\section{Erosão e Terra carregada}

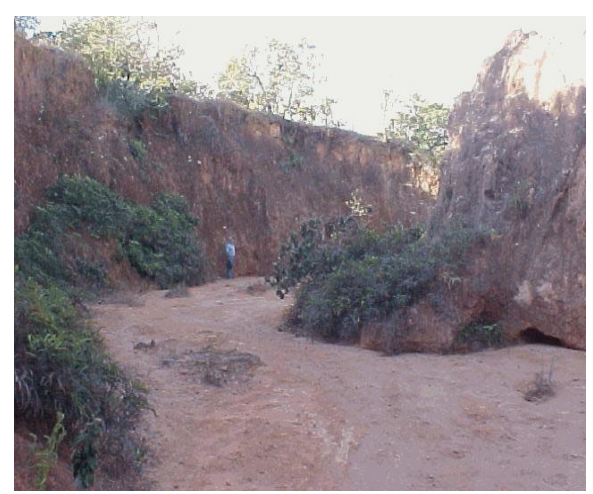

Erosão

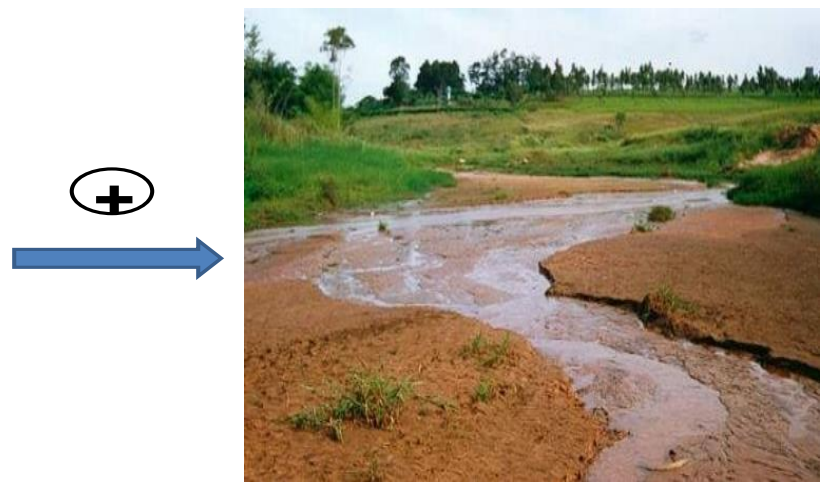

Terra carregada

Normalmente a 'Terra carregada' se deposita no fundo de rios e lagos, diminuindo sua profundidade e consequentemente, a sua capacidade de armazenamento de água. É o que chamamos de assoreamento.

\section{Terra carregada e Reservatórios de água}

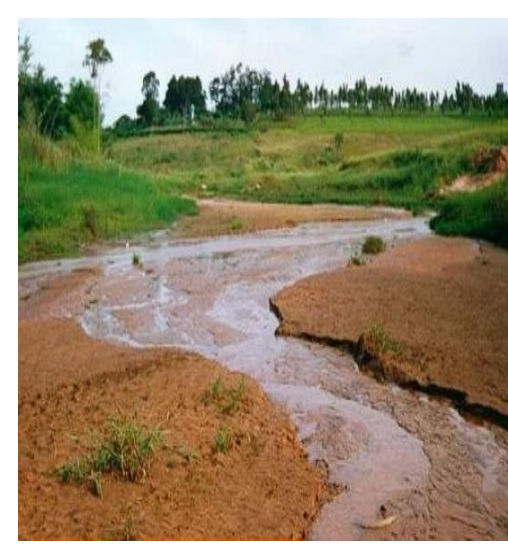

Terra carregada

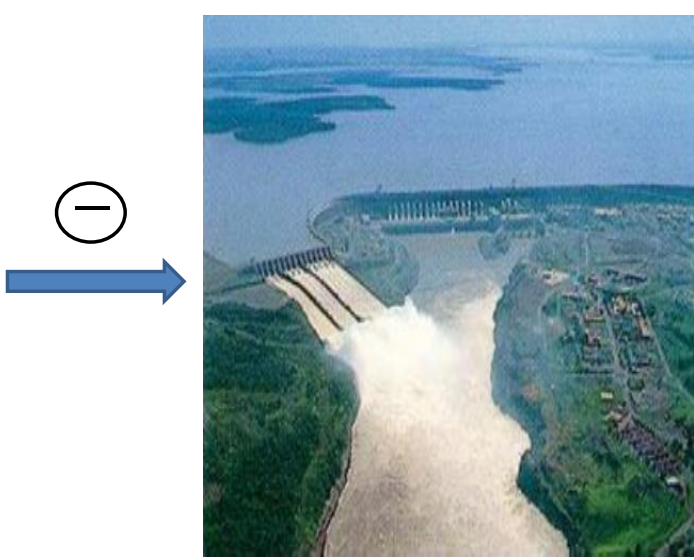

Reservatórios de água 
Ao se diminuir a capacidade dos reservatórios de água, teremos como principais consequências, a redução da capacidade de usos da água nas diversas modalidades, seja para o consumo humano, irrigação de lavouras, produção de energia, entre outros.

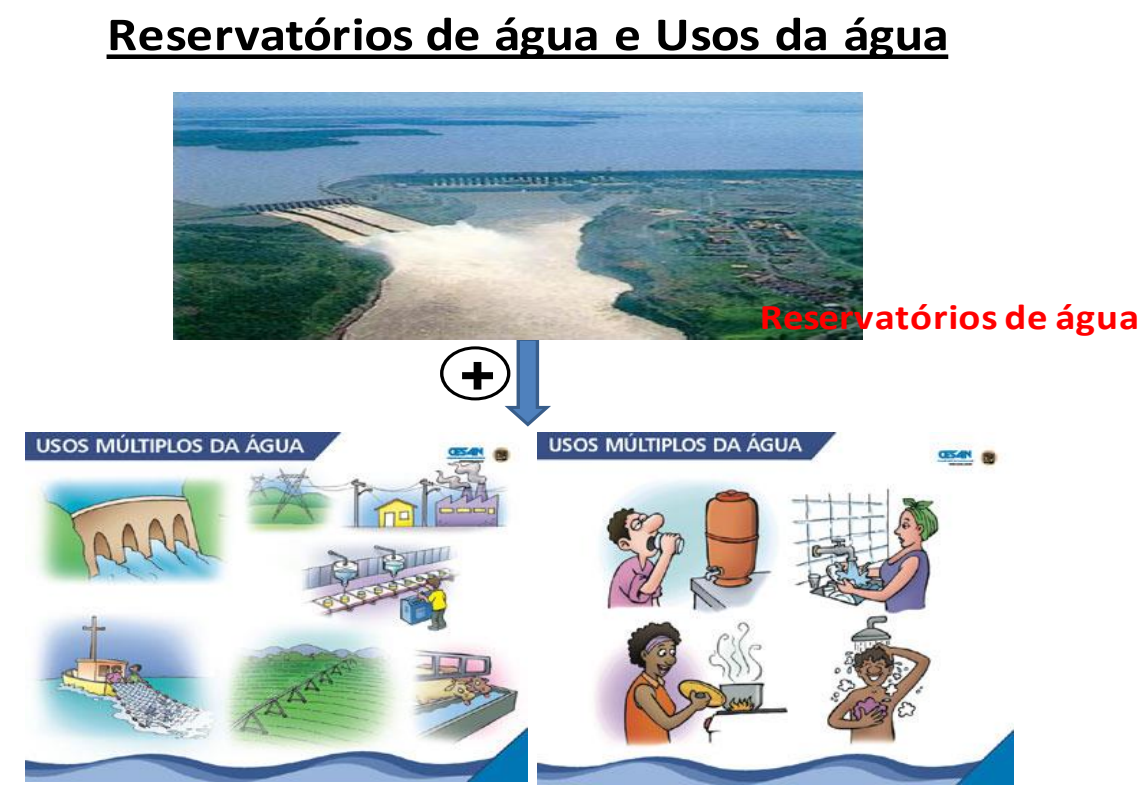

Recentemente o Brasil passou por uma grave crise de abastecimento em vários estados da federação, entre elas, destacou-se o estado de São Paulo, que viu a necessidade de fazer um racionamento de água, prejudicando as pessoas e a economia da região.

A baixa nos reservatórios de água no Brasil, também leva a um encarecimento da energia, pois se passa a utilizar mais a geração de energia elétrica através de usinas que consomem combustíveis e com isso, ocorre um aumento do gasto de produção, que é repassado ao consumidor final. Esse tipo de produção de energia, também gera um dano ambiental, ao despejar várias toneladas de poluentes na atmosfera, derivados da queima do combustível.

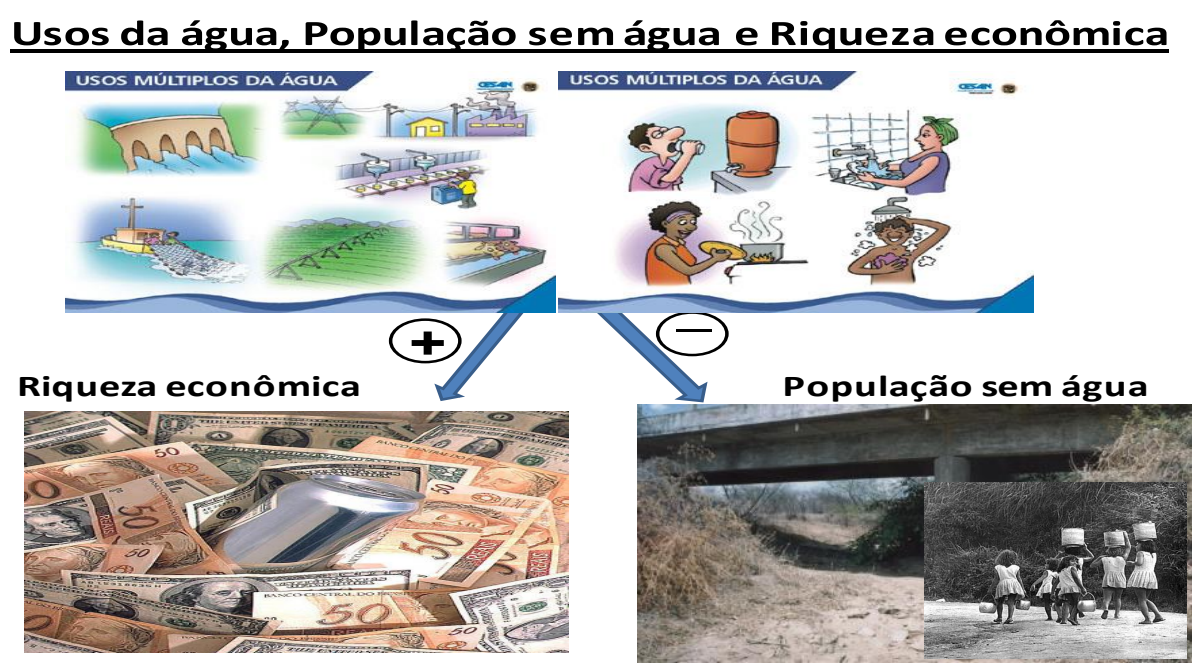


A derrubada da vegetação, também gera problemas ambientais, como a perda da 'Biodiversidade' ${ }^{6}$. Biodiversidade será tratada aqui como a variedade de espécies de uma região e a quantidade de espécies semelhantes que proporcionam um equilíbrio ao ambiente.

\section{Vegetação e Biodiversidade}

\section{Vegetação}

Terra com vegetacao Terra sem vegetacao

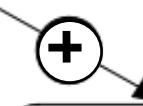

Biodiversidade

Com a diminuição da biodiversidade, a possibilidade de se descobrir novos 'Fármacos e alimentos' também é reduzida. Isso diminui a capacidade de um país gerar riquezas e abastecer sua população com alimentos.

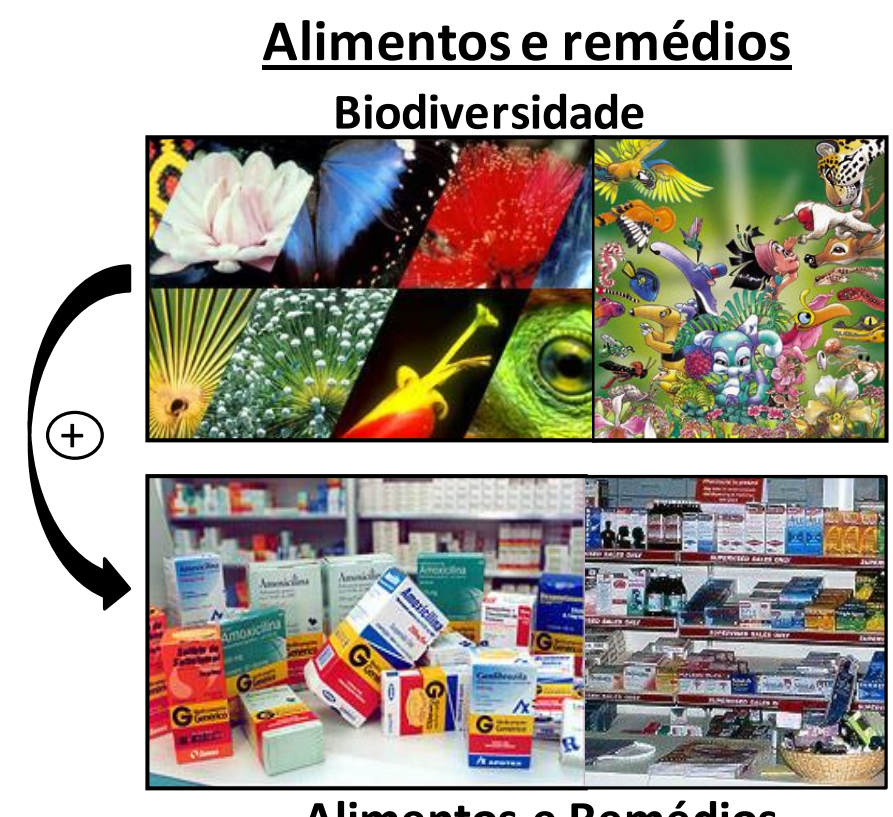

Alimentos e Remédios

\footnotetext{
${ }^{6}$ Imagem produzida automaticamente por DynaLearn.
} 
A imagem anterior mostra a relação de causalidade positiva entre a 'Biodiversidade' e a quantidade 'Alimentos e Remédios'. A mesma relação é apresentada de outra forma, no quadro $^{7}$ a seguir:

\section{Biodiversidade e Alimentos e Remédios}

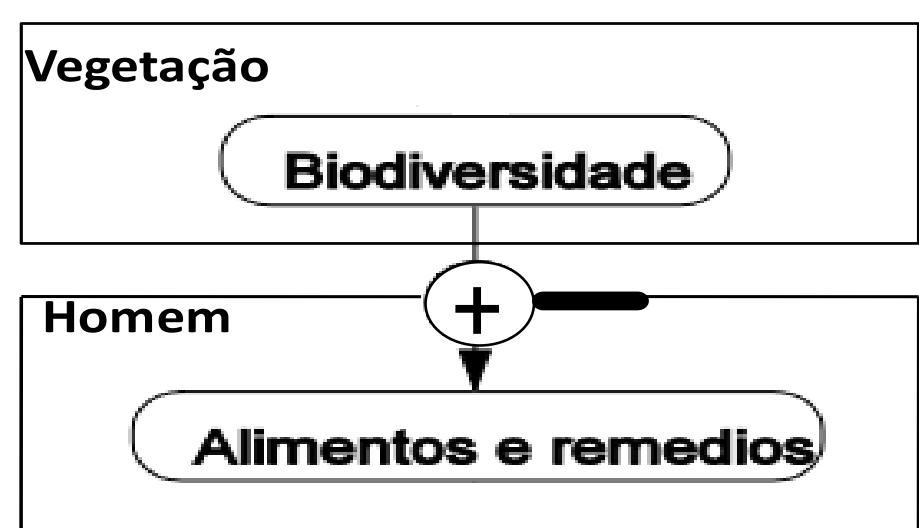

O‘Desmatamento’ gera várias consequências que afetam o homem. Esses efeitos podem ser observados de diversas formas, como na imagem ${ }^{8}$ a seguir: 


\section{Tudo influencia o Homem}

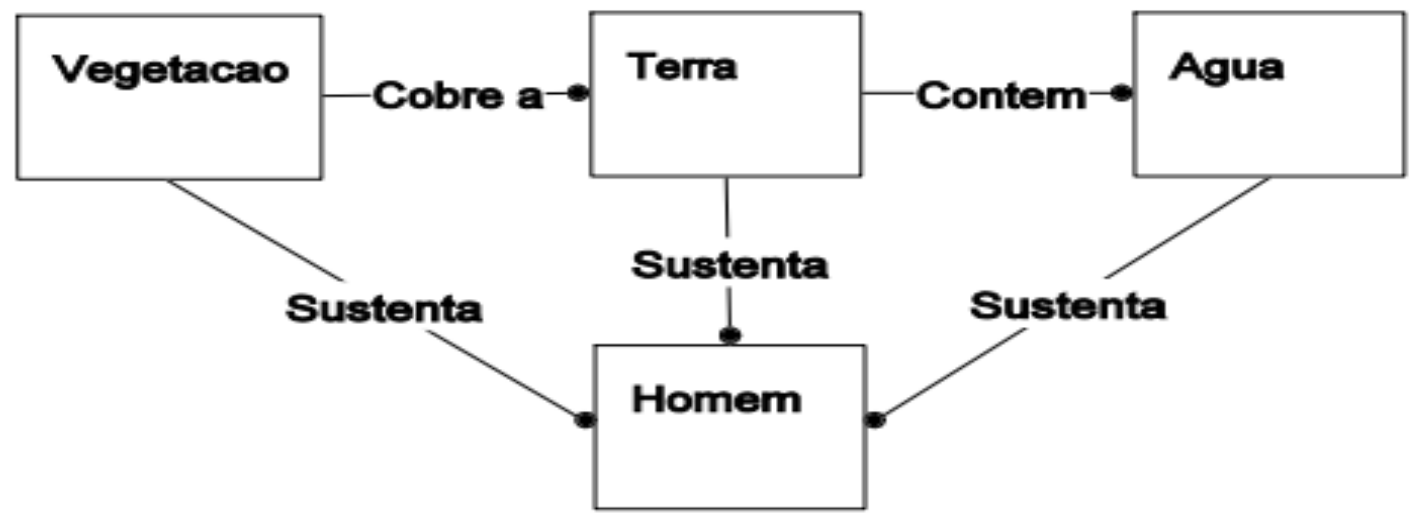

Todas as relações apresentadas anteriormente podem ser visualizadas por meio de um modelo causal $^{9}$, contendo todas as informações relativas ao modelo e às relações de causalidade.

\section{Modelo causal: tudo afeta a economia}

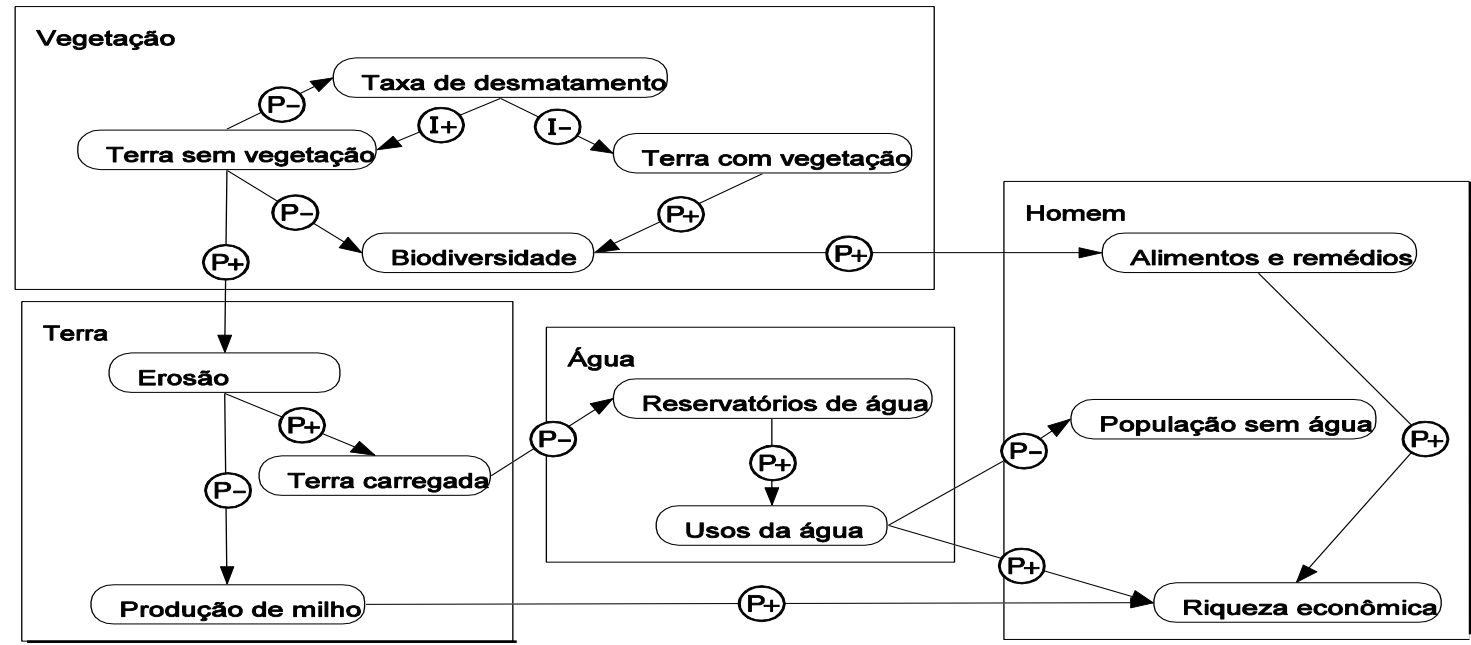

\footnotetext{
${ }^{9}$ Imagem produzida automaticamente por DynaLearn.
} 
Feito a apresentação dos modelos por meio de imagens, pode-se estimular os alunos a pensarem sobre questões, que não estão explicitamente apresentadas nos modelos, mas que podem proporcionar momentos de debates e discussões sobre problemas que nos afetam diretamente. Segue um exemplo de atividade que pode ser desenvolvida ao final de um encontro:

\section{Pergunta}

O desmatamento parando e a regeneração, ou replantio aumentando, o que acontece com a população sem água?

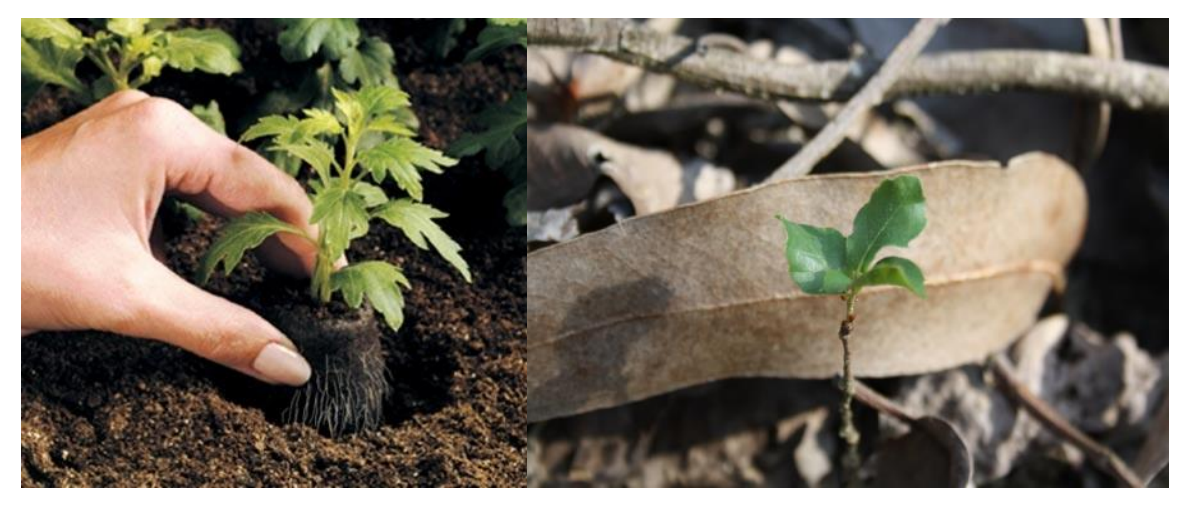




\section{ATIVIDADES PROPOSTAS}

Nos encontros seguintes, são apresentados os fragmentos de modelos por meio de imagens, seguidos do modelo causal e finalizando com a simulação do modelo no software. $\mathrm{Na}$ medida em que os alunos vão compreendendo a dinâmica do sistema representado no modelo 'Desmatamento', os alunos passam a responder com um grau de complexidade cada vez maior, de acordo com os tipos de perguntas que são feitas a eles, da maneira mais variada possível.

A estrutura das perguntas utilizadas:

- "Se... Então..."

- "Algo(AUMENTA ou DIMINUI)

Porque... Outra coisa (AUMENTA ou DIMINUI)".

- Questões que apresentem modelos para serem completados ou respondidos, como os exemplos abaixo:

Sobre os modelos abaixo, completeas lacunas com AUMENTA, DIMINUI ou ESTABILIZA:

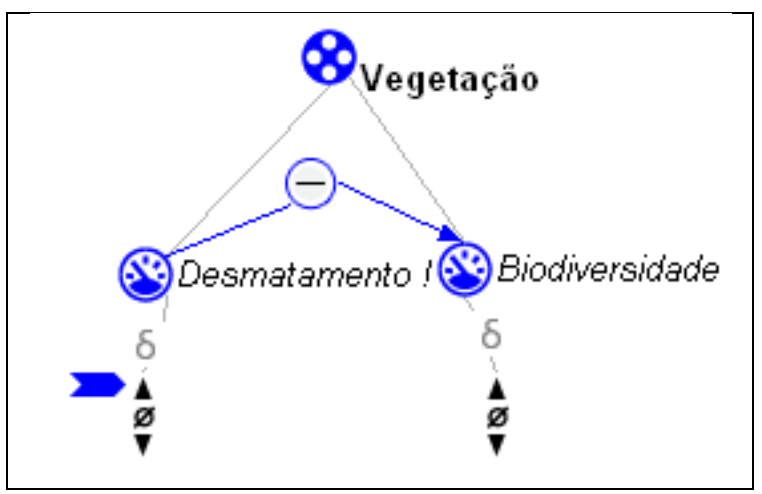

Se Desmatamento AUMENTA,

Então Biodiversidade...

Complete os modelos abaixo com os sinais de (+) ou (-) e complete o espaço em branco com: POSITIVA ou NEGATIVA:

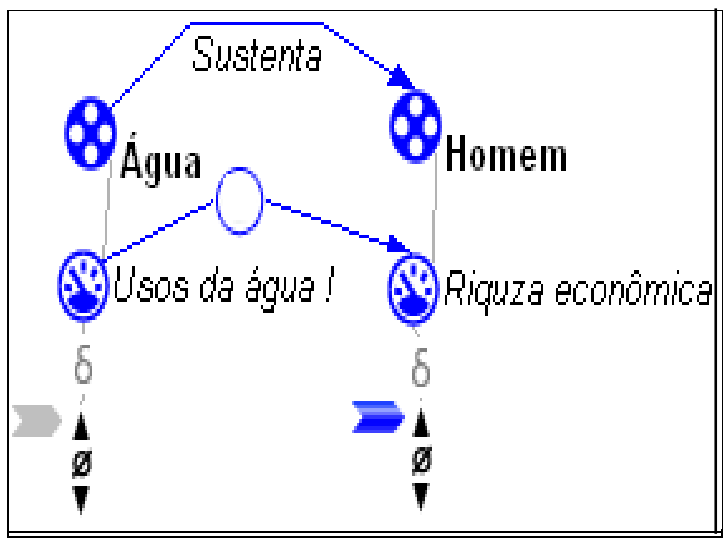

A relação entre as quantidades Usos da água e Riqueza econômica é identificada por uma seta

com uma influência 
Complete o modelo abaixo com as setas indicando o que ocorre com as derivadas de cada quantidade:

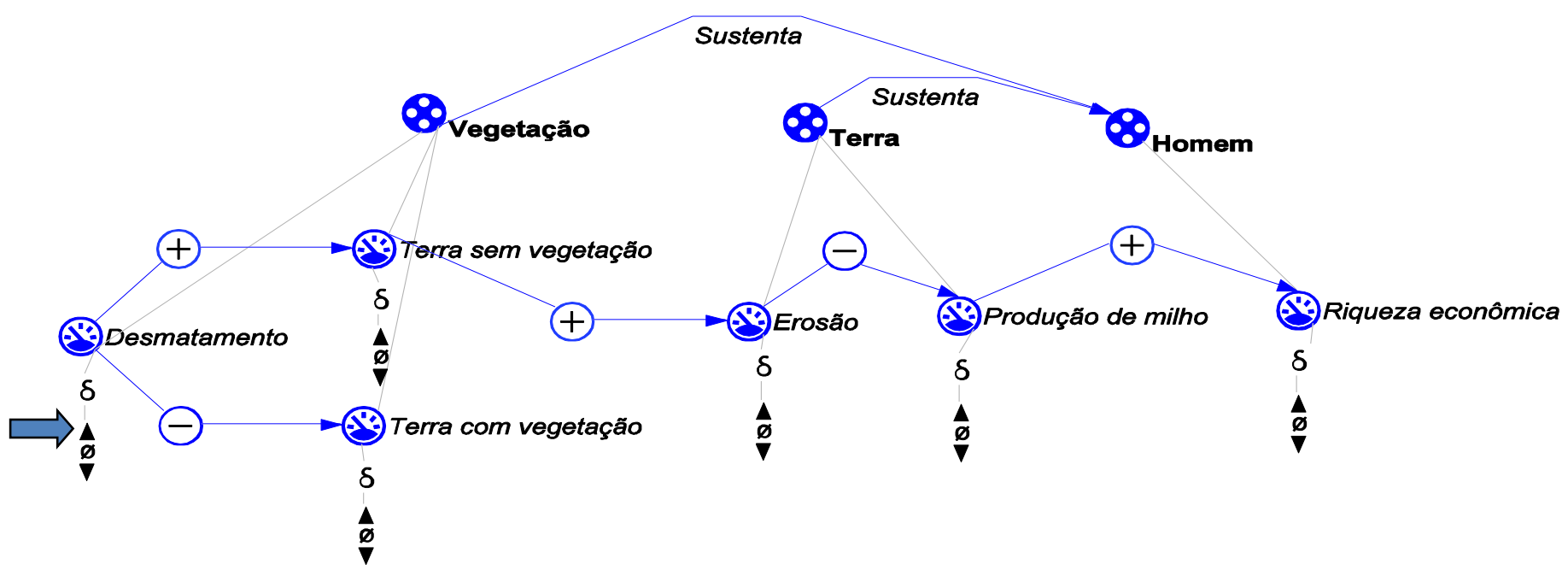

Após a execução dessas atividades, foi possível observar que os alunos conseguiam perceber os silogismos e fazer uso do raciocínio lógico de forma a buscar compreender o que ocorria com as quantidades representadas nos modelos. Além de prever os resultados a partir de uma variação de uma quantidade inicial, eles também foram capazes de fazer o inverso, ou seja, a partir de um resultado de uma quantidade representada no fim do modelo, eles conseguiam, por meio da observação das relações entre as quantidades, deduzir o que estava ocorrendo com a quantidade que influenciou a quantidade seguinte a ter aquele tipo de resultado. Para se verificar o que foi descrito, eles respondiam questões como as apresentadas a seguir:

Complete o modelo e as frases:

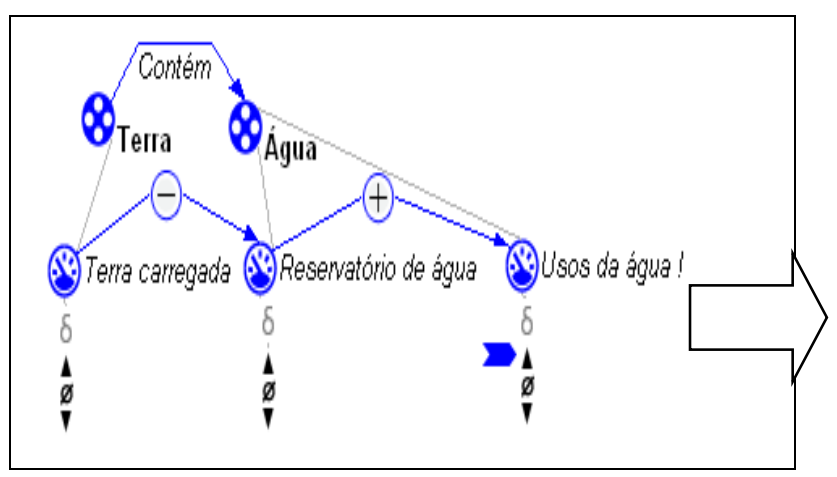

SeTerra carregada...

EntãoReservatórios de água ....

SeReservatóriosdeágua ...

EntãoUsos da águaAUMENTA. 

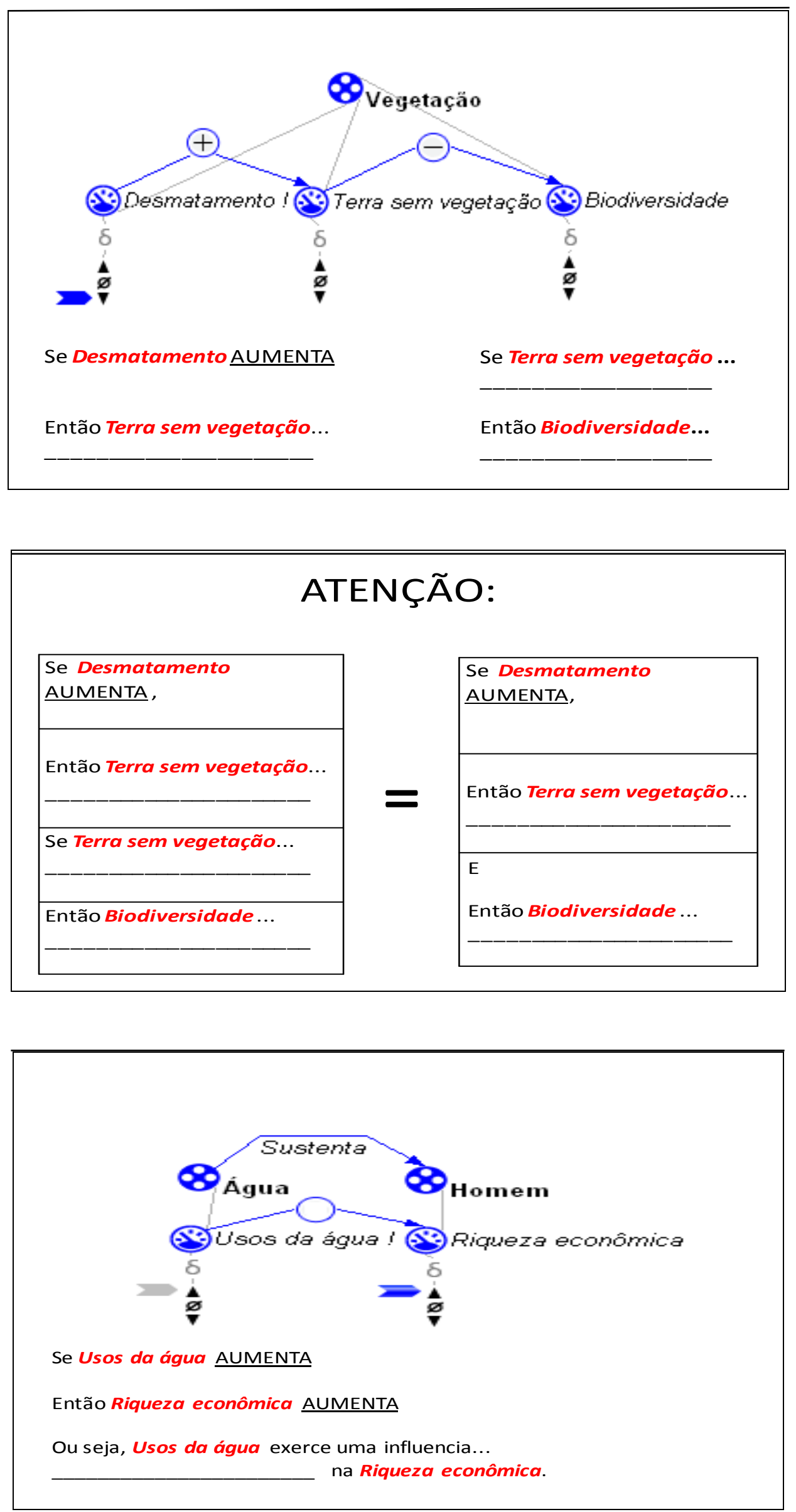


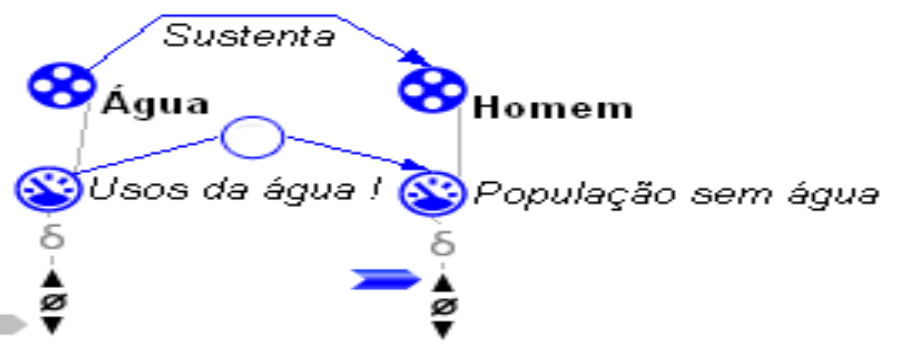

Se Usos da água DIMINUI

Então População sem água AUMENTA

Ou seja, Usos da água exerce uma influencia... na População sem água.
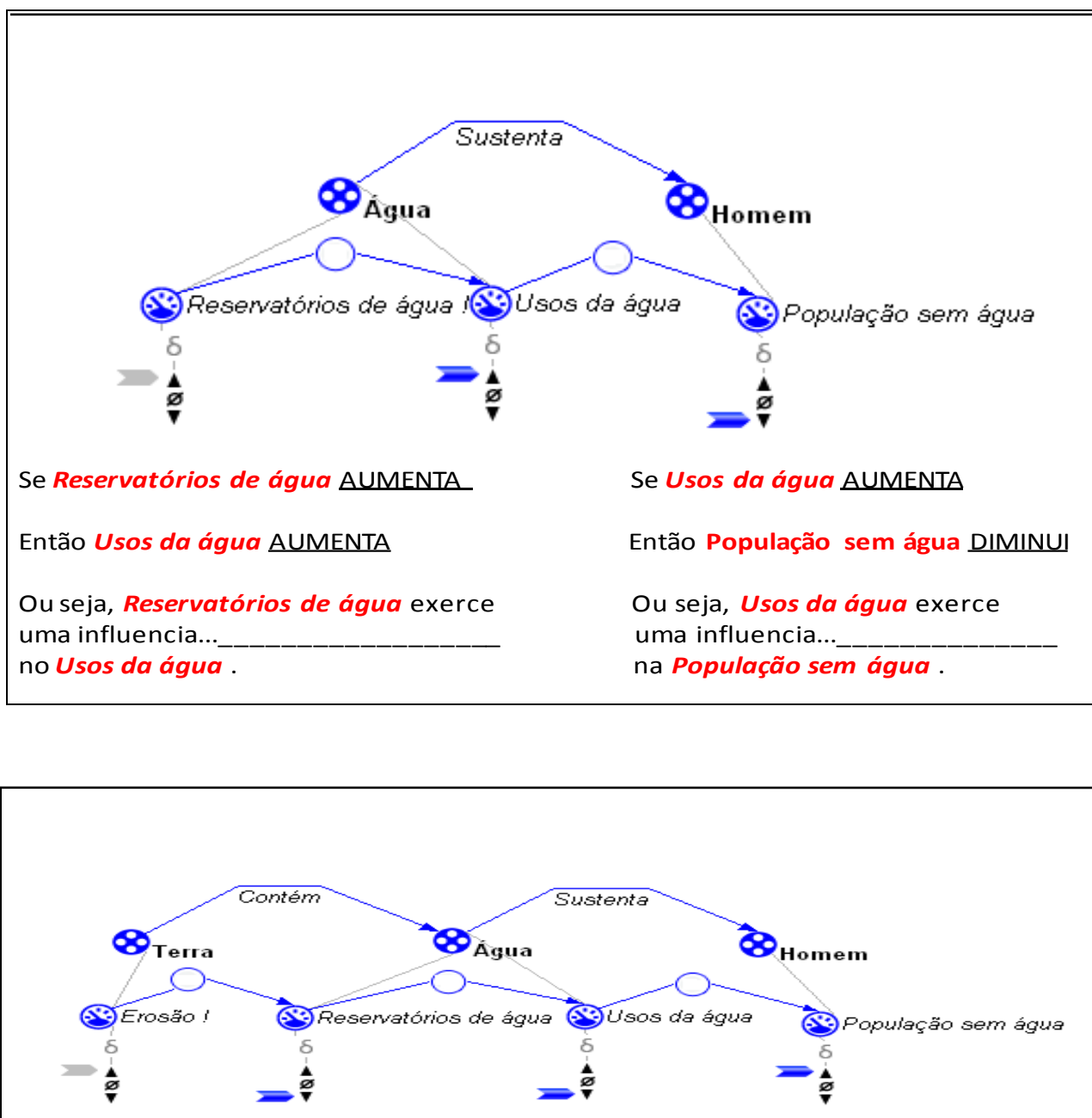

Se Erosão AUMENTA, Então Reservatórios de água Diminui. Ou seja, Erosão exerce uma influencia... nos Reservatórios de água.

Se Reservatórios de água Diminui, Então Usos da água Diminui. Ou seja, Reservatórios de água exerce uma influencia... no Usos da água.

Se Usos da água Diminui, Então População sem água AUMENTA. Ou seja, Usos da água exerce uma influencia...________ na População sem água. 


\section{APRENDENDO NA PRÁTICA}

Dando sequência ao processo de construção do conhecimento e buscando desenvolver a habilidade em lidar com ferramentas computacionais, é proposta uma atividade de modelagem prática com os alunos.

Mexer com o computador pode parecer fácil para muitas pessoas, porém, para alguns, esse recurso impõe medo e expõe dificuldades particulares em manusear as ferramentas tecnológicas. Por isso, o acompanhamento do professor é indispensável na execução dessa atividade.

Para auxiliar no desenvolvimento dessa atividade, propõe-se a utilização de um tutorial de como se criar modelos no DynaLearn e outro tutorial, para se desenvolver modelos no nível LS2, como apresentados a seguir:

\section{Tutorial 1-Criação de modelo no DynaLearn}

Após instalar o software e clicar no ícone doDynaLearn, na área de trabalho, irá aparecer a seguinte tela:

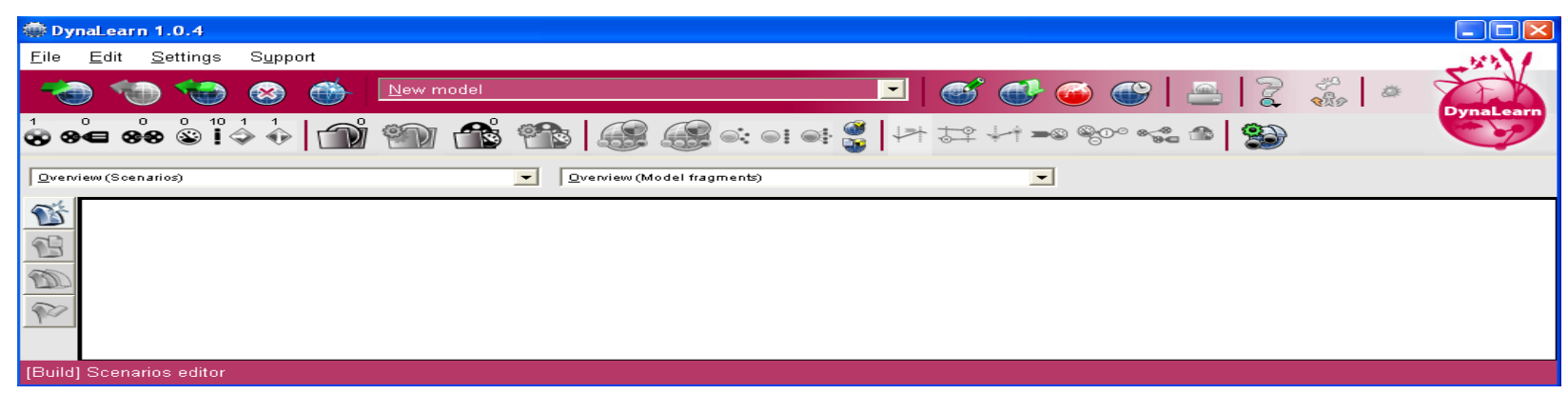

Para criar um modelo novo, tem que clicar na imagem indicada pela seta, ou ir no menu "file" e clicar em "start new model".

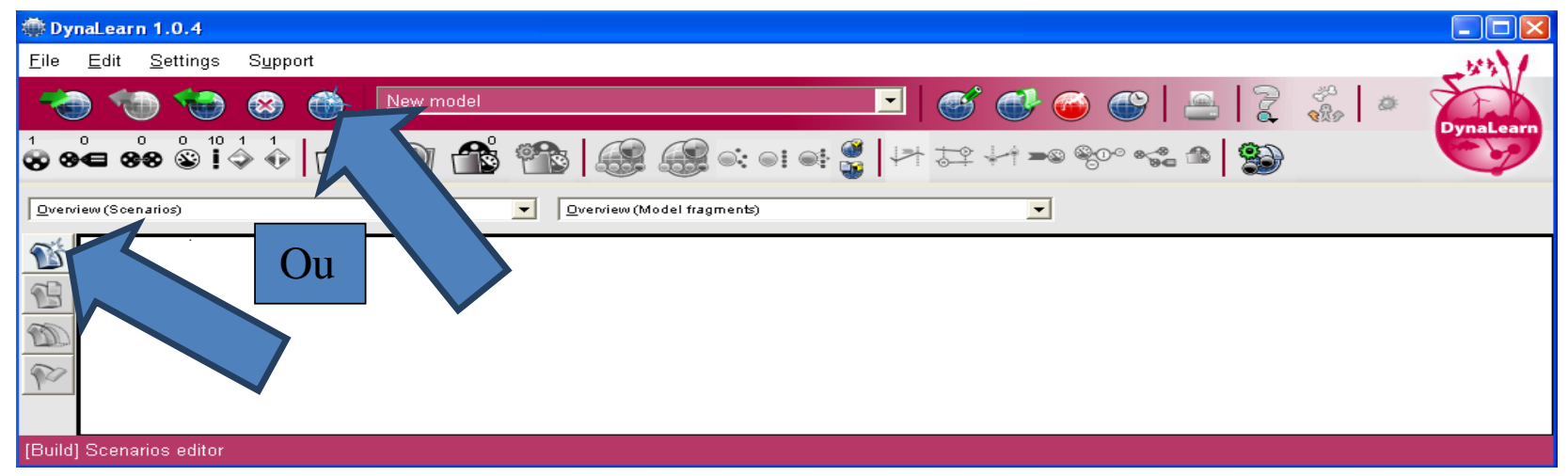


Feito isto, aparecerá a seguinte caixa:

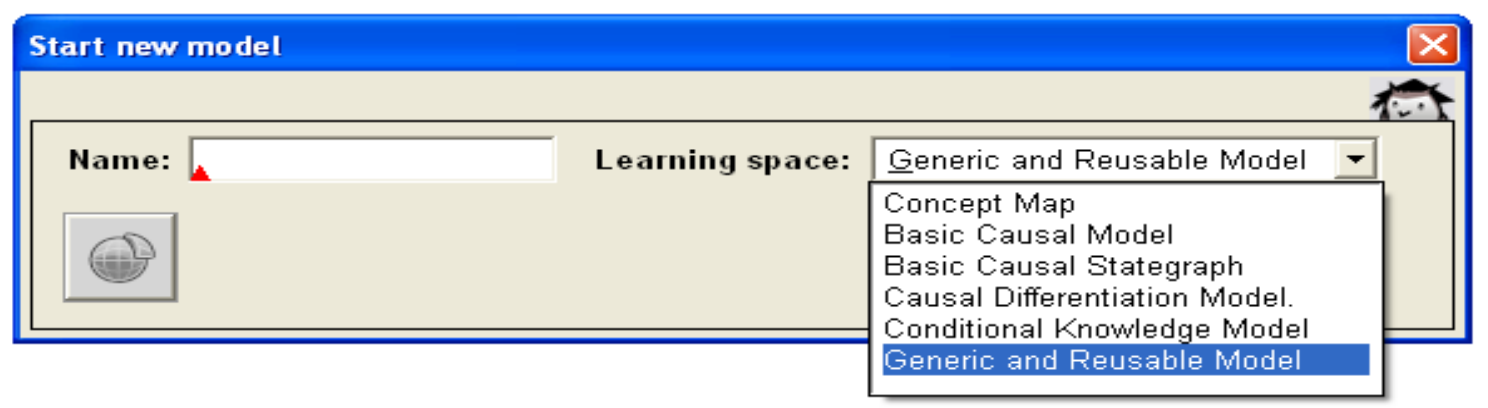

Selecione um tipo de Learning Space(LS), que pode ser:

- LS1- Conceptmap (Mapa conceitual)

- LS2- Basic causal model (Modelo causal básico)

- LS3- Basic causal stategraph (Modelo causal básico com gráfico de estado)

- LS4- Causal differentiationmodel (Modelo de diferenciação causal)

- LS5- Conditionalknowledgemodel (Modelo de conhecimentocondicional)

- LS6- Genericandreusablemodel (Modelo genérico e reutilizável)

Então, escreva o nome do modelo no espaço "name", acrescentando ao final as siglas "LS",que é a abreviação de "Learning Space" (Espaço de aprendizado) e o número do nível que será utilizado para criar o modelo. Ao final, clica-se no item indicado pela seta, como na imagem na página seguinte:

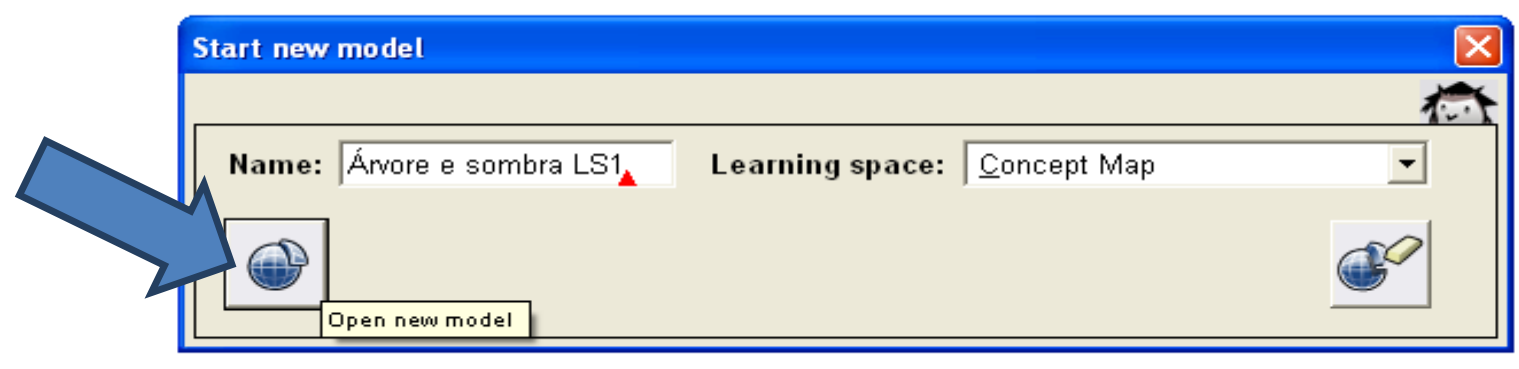

Pronto, está criado o seu modelo. Repare que no exemplo, dei o nome "Árvore e sombra LS1", pois escolhi o nível do modelo que irei trabalhar, que é o learning space: Concept Map, ou LS1.

Não há como converter um modelo já criado de um LS para outro. Portanto, para se trabalhar em outro nível, terá que se repetir o processo descrito anteriormente, desde o início, selecionando outro Learning Space. Lembrando sempre de colocar o seu respectivo LS ao nome dado para o modelo, pois isto facilita a identificação e o controle do que se modela.

\section{$\underline{\text { Bibliografia }}$}

Bredeweg, B., Salles, P., Souza, A., Noble, R., Zitek, A., Borisova,P. \&Leiba, M.. . Projeto, EC FP7 projeto STREP231526, Deliverable D6.5.,2013. 
$\underline{\text { Tutorial } 2 \text { - Modelagem em LS2 }}$

\section{Modelagem em Dynalearn \\ Tela principal Dynalearn}

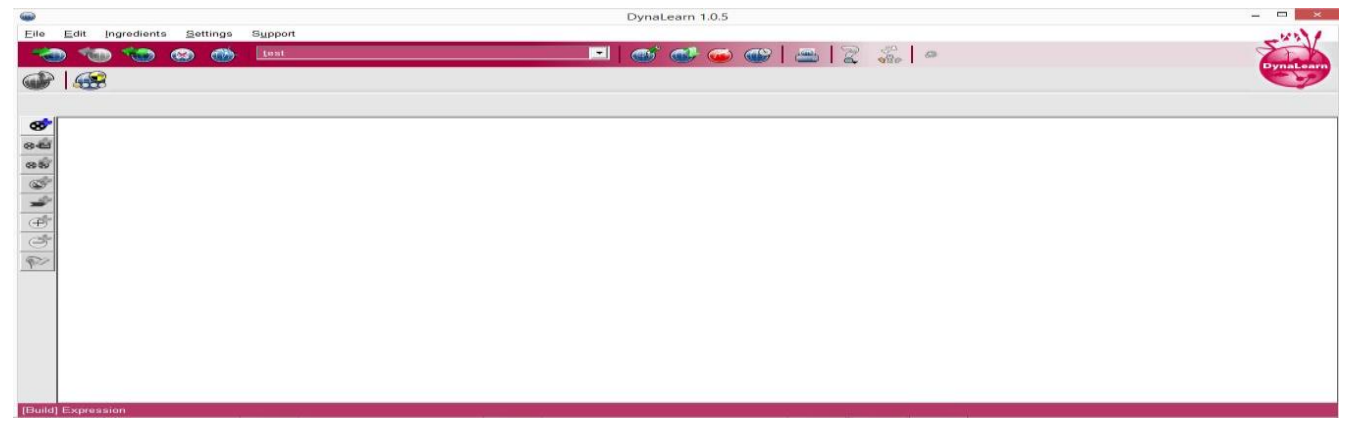

\section{Principais funções do Dynalearn}

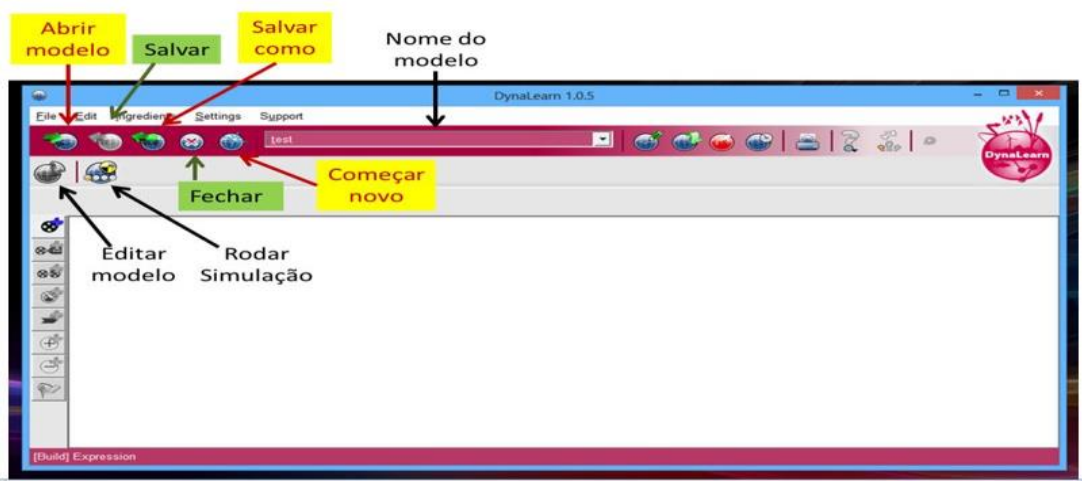

\section{Botões da modelagem no LS2}

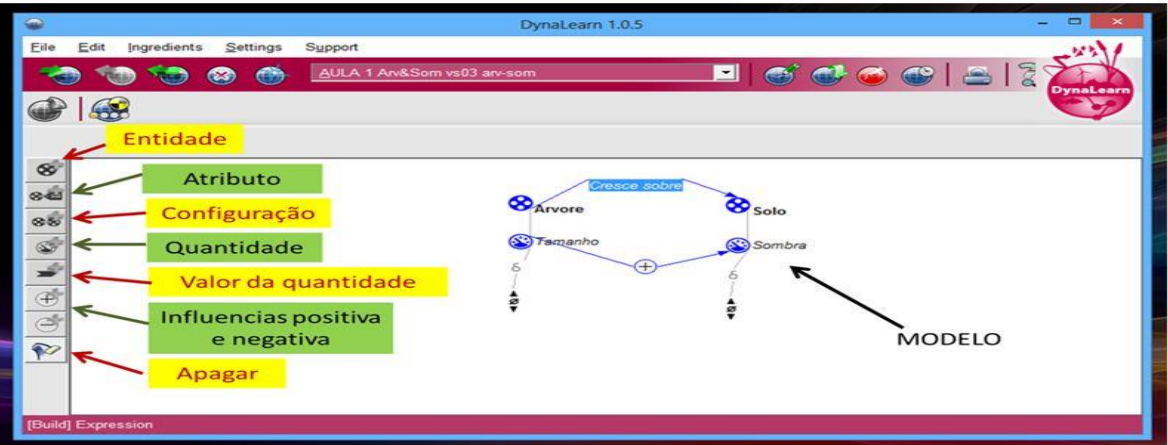


Como trata-se do primeiro contato com as ferramentas do software DynaLearn, o roteiro mostrando o passo a passo do que se pretende trabalhar, auxilia consideravelmente o desenvolvimento da atividade, de forma mais autônoma pelos alunos, que podem ser avaliados durante a confecção dos modelos e da conclusão das atividades propostas.O roteiro completo para a execução dessa atividade encontra-se em anexo.

Os resultados obtidos com essa atividade podem demonstrar o grande potencial de abstração dos alunos, apesar de reproduzirem parte do modelo já trabalhado, eles passam a fazer perguntas, questionando a possibilidade de se inserir novas quantidades e até mesmo novas entidades aos modelos.

Para dar sequência às relações causais do modelo, deve-se sempre trabalhar com o uso de imagens para se explicar os conceitos abordados e fazer uso de questões do tipo "Se... Então...” de maneira a verificar o entendimento da dinâmica do sistema representado por meio do modelo.

Ao final, é proposto aos alunos, que escrevam um pequeno texto relatando o que ocorre em uma região onde há desmatamento excessivo. O texto tem que abordar conceitos como a biodiversidade, os recursos hídricos e respondendo as perguntas a seguir:

Como o desmatamento afeta aos homens?

O que poderia ser feito para se reverter o quadro negativo?

Para auxiliar essa atividade, pode-se utilizar textos complementares, como o texto sobre o conflito entre Índios Ka'apor e madeireiros. ${ }^{10}$ Além disso, a estrutura das perguntas motivava aos alunos querer escrever sobre o que perceberam a cerca de fatos descritos no texto sugerido.

Estrutura da atividade:

Responda a pergunta a seguir: Por que o desmatamento prejudica os povos da floresta?

Apresente pelo menos 2 motivos/ razões.

\begin{tabular}{|r|r|}
\hline 1. & \\
\hline 2. & \\
\hline
\end{tabular}

Ao realizar a atividade como proposta acima, os alunos conseguem compreender os fenômenos ocorridos a partir do desmatamento e como isso afeta também aos "povos da

\footnotetext{
${ }^{10}$ Texto: 'Conflito entre Índios Ka'apor e madeireiros'. Disponível em: http://g1.globo.com/natureza/noticia/2014/09/indios-realizam-operacao-para-conter-desmatamento-em-area-domaranhao.htm
} 
floresta", sendo que, utilizam argumentos que envolvem estruturas presentes nos modelos, sempre os relacionando as respostas ao que estava sendo descrito no texto.

A mesma metodologia utilizada nos encontros anteriores pode ser utilizada nos encontros seguintes, buscando sempre fazer uso de imagens nas explicações dos conceitos, relacionando com os sinais presentes no "Glossário" (contido no DVD descrito no início desse módulo), e propondo desafios, por meio de questionários e elaboração de textos que explorem: os conceitos científicos, as relações causais e o raciocínio hipotético dedutivo. Também devem ser trabalhados os aspectos linguísticos como: o uso dos verbos, artigos, pronomes e outras estruturas gramaticais, presentes nas sentenças escritas a respeito dos modelos. 


\section{CONSIDERAÇÕES FINAIS}

Deve-se sempre buscar estimular os alunos a produzirem textos descrevendo as situações evidenciadas nos modelos e o uso adequado do vocabulário escrito em língua portuguesa. Para isso, pode ser necessário o auxílio de um professor da área de linguagens, porém, essa abordagem permite uma possível interação interdisciplinar.

É interessante que os alunos sejam avaliados ao final de cada encontro, seja por meio de uma avaliação qualitativa da participação do aluno durante o desenvolvimento das aulas; pela produção de textos; ou por meio de um pequeno teste que pode conter perguntas simples em que se julguem as afirmativas como verdadeiras ou falsas.

Como estímulo ao envolvimento e a participação dos alunos, a nota obtida no curso pode ser utilizada como ponto extra pelos professores das áreas de Ciências, Biologia, Português ou outras disciplinas envolvidas, afinal, o curso pode levar a uma melhor compreensão e desenvolvimento do aluno nessas disciplinas. 


\section{BIBLIOGRAFIA CONSULTADA}

Bredeweg, B., Salles, P., Souza, A., Noble, R., Zitek, A., Borisova,P. \&Leiba, M.. . Projeto , EC FP7 projeto STREP231526, Deliverable D6.5.,2013.

Feltrini, G. M. Aplicação de modelos qualitativos a educação científica de surdos. Brasília, 2009. 222 f. Dissertação (Mestrado em Ensino de Ciências) - Instituto de Ciências Biológicas, Universidade de Brasília.

FORBUS, K. D. Qualitative Process Theory. Artificial Intelligence. Amsterdam: IOS Press/Omasha, n. 24, 85-168. 1984.

KELMAN, C. A.; TUXI, P. Intérprete educacional ou professor? A atuação profissional do interprete da língua de sinais no ensino de Ciências. In: SALLES, P. B. A. e GAUCHE, R. (Org.). Educação Científica, Inclusão Social e Acessibilidade. $1^{a}$ ed. Goiânia: Cânone Editorial, p.79-103, 2011.

RESENDE, M. M. P.Avaliação do uso de modelos qualitativos como instrumento didático no ensino de Ciências para estudantes surdos e ouvintes. Brasília, 2010. 162 f. Dissertação (Mestrado em Ensino de Ciências) - Instituto de Ciências Biológicas, Universidade de Brasília.

SALLES, P.; GAUCHE, R. e VIRMOND, P. (2004) A Qualitative Model of Daniell Cell for Chemical education of deaf students: scientific education and acquisiton of Portuguese as a second language. In: LESTER, J.C.; VICARI, R.M.; PARAGUAÇU, F. (eds.) Intelligent Tutoring Systems: 7thInternational Conference, ITS 2004, Proceedings. Série Lecture Notes in Computer Science, vol. 3220, pp. 870-872, Berlim - Heidelberg, Springer Verlag.

SALLES, P.; LIMA-SALLES, H.; BREDEWEG, B. (2005) The Use of Qualitative Reasoning Models of Interactions Between Populations to Support Causal Reasoning of Deaf Students. In: LOOI, C.-K.; MCCALLA, G.; BREDEWEG, B., BREUKER, J. (eds.) Artificial Intelligence and Education: Supporting learning through Intelligent and Socially Informed Technology. Amsterdam, IOS Press / Omasha, pp. 579-586, 2005.

SALLES, P.; FELTRINI, G RESENDE, M.; LIMA-SALLES, H.Modelos Qualitativos para o Ensino de Ciências de alunos surdos do Ensino Médio.Manual Instrucional.Brasilia: Universidade de Brasília, Projeto LAPEVI, 2013. 109 p. (Manuscrito não publicado). 


\section{ANEXOS}

Anexo 1-Roteiro da atividade prática

\section{Atividade prática}

Observe o modelo abaixo e siga os passos para a construção do mesmo:
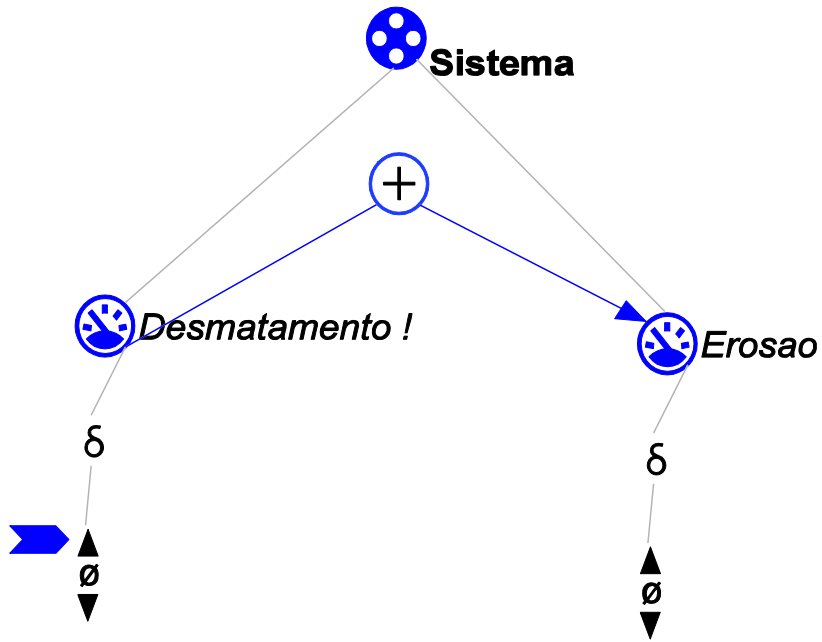

$1^{\circ}$-Crie o modelo no LS2 com o nome "Desmatamento M1-LS2", lembrando de selecionar o nível "Basic Causal Model ou LS2". Use o tutorial fornecido para isso.

Utilize o segundo tutorial para os passos seguintes:

$2^{\circ}$ - Crie a entidade com o nome "Sistema".

$3^{\circ}$ - Dê um clique na entidade "Sistema", para selecioná-la e em seguida no ícone "quantidade".

Então abrirá a seguinte janela:

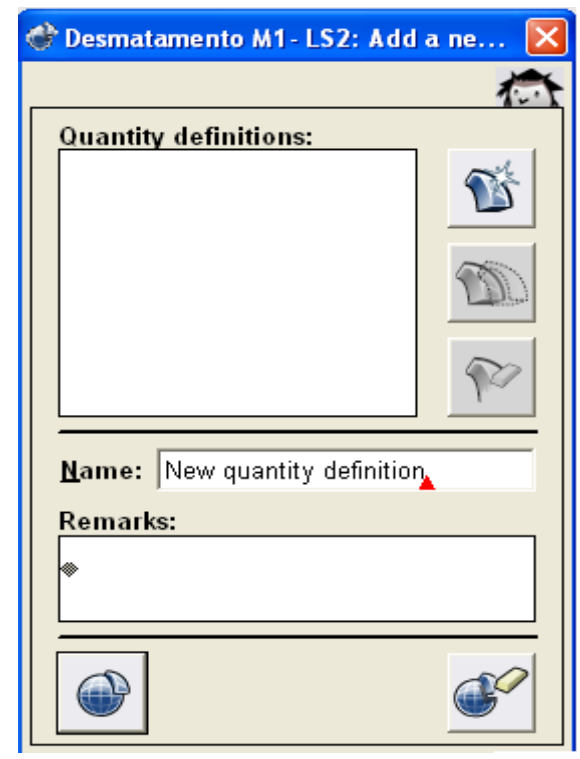


Dê um clique no ícone "Name". Lembre-se de apagar o texto que já se encontra na caixa de texto do "Name". Em seguida salve a "Quantidade" clicando no ícone (-).Pronto, você criou a Quantidade "Desmatamento na Entidade "Sistema".

Faça o mesmo para criar a Quantidade "Erosão".

$4^{\text {o}}$ - estabeleça uma relação de causalidade entre as quantidades. Para isso, você deve selecionar as duas quantidades com o mouse ou clicando em uma, segurando o botão 'shift'

no teclado e depois clicando na outra. Então aparecerá as opções

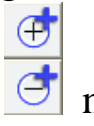
Escolha a mais adequada. Ou seja, se uma quantidade aumenta e a outra aumenta pela ação da primeira, como ambas estão aumentando, selecionamos o sinal de $\oplus$. Caso ocorra de uma diminuir e a outra também, ocorrerá o mesmo e utilizaremos o sinal de $(+)$, pois ambas se deslocam no mesmo sentido. Mas caso ocorra de uma aumentar e a outra diminuir, usamos o sinal de $\Theta$, pois ele indica que as quantidades caminham em caminhos opostos, ou seja, se uma aumenta a outra diminui, ou se uma diminui a outra aumenta. Portanto, para esse exemplo selecionaremos o sinal de $\oplus$, então abrirá uma nova janela, em seguida clicamos no ícone

Feito isso, selecionamos a Derivada representada pela imagem $\stackrel{\phi}{\nabla}$. Podemos selecionar aumentando $\downarrow$, diminuindo $\mathbf{\nabla}$, ou estável $\varnothing$, clicando sobre uma dessas possibilidades e depois clicando no icone $\_$, que está na lateral da tela lateral.

Ao rodar a simulação do modelo, veremos o resultado clicando na imagem que está acima do modelo, no canto esquerdo da tela.

Observe o resultado da siulação e responda:

SE desmatamento aumenta...

ENTÃO erosão

(aumenta, diminui, permanece estável)

SE desmatamento diminui...

ENTÃO erosão

(aumenta, diminui, permanece estável)

SE desmatamento permanece estável...

ENTÃO erosão

(aumenta, diminui, permanece estável) 